\title{
Revisão do gênero Antiteuchus Dallas (Heteroptera, Pentatomidae, Discocephalinae) ${ }^{1}$
}

\author{
José Antônio Marin Fernandes² \& Jocélia Grazia ${ }^{3,4}$
}

\author{
${ }^{1}$ Contribuição no 486 do Departamento de Zoologia da UFRGS. \\ ${ }^{2}$ Centro de Ciências Biológicas, Universidade Federal do Pará, Rua Augusto Corrêa no 1, 66075-110 Belém, PA, Brasil. \\ ${ }^{3}$ Departamento de Zoologia, Instituto de Biociências, Universidade Federal do Rio Grande do Sul, Av. Bento Gonçalves, 9500, bloco IV, \\ Prédio 43435, 91501-970 Porto Alegre-RS, Brasil. \\ ${ }^{4}$ Bolsista CNPq.
}

\begin{abstract}
Revision of the genus Antiteuchus Dallas (Heteroptera, Pentatomidae, Discocephalinae). The genus Antiteuchus Dallas, 1851 composed of 46 species is revised. The genus and the known species are redescribed based on the male external genital structure and some external characteristics of the body. The supraspecific structure is refused and Neodine Kirkaldy, 1909 is considered synonymous of Antiteuchus. The species are split among six new groups here proposed: A. amplus, A. supinatus, A. peruensis, A. tesselatus, A. marmoratus and A. mixtus. Eight new species are described: A. amapensis sp. nov., A. beckerae sp. nov., A. doesburgi sp. nov., A. exiguus sp. nov., A. ledeburi sp. nov., A. marini sp. nov., A. melanicus sp. nov. and A. similis sp. nov. Nine species and one subspecies are synonymized. Antiteuchus varians Ruckes, 1964 is considered a junior synonym of $A$. pallescens Stål, 1868; A. englemani Rolston, 1993 of A. amplus (Walker, 1867); . tripterus limbativentris Ruckes, 1964 and A. minor Engleman, 1983 of A. tripterus (Fabricius, 1787); A. fuscus (Ruckes, 1959), A. piceus (Palisot de Beauvois, 1805), A. subgibbus Engleman, 1983, A. subimpunctatus Ruckes, 1964, A. unicolor (Westwood, 1837) and A. variolosus (Westwood, 1837) of A. mixtus (Fabricius, 1787). Antiteuchus tatei (Ruckes, 1958) is considered species inquirenda. Empicoris marmoreus Spinola, 1837 is considered incertae sedis and species inquirenda. The male of A. pictus, so far unknown, is described. Identification keys for the males of the species of Antiteuchus as well as for the species groups are presented.
\end{abstract}

KEYWORDS. Discocephalini; morphology of genitalia; systematics.

RESUMO. Revisão do gênero Antiteuchus Dallas (Heteroptera, Pentatomidae, Discocephalinae). O gênero Antiteuchus Dallas, 1851 com 46 espécies descritas é revisado; as espécies são redescritas com base na morfologia externa da genitália do macho e em algumas características da morfologia geral do corpo. Neodine Kirkaldy, 1909 é considerado sinônimo junior de Antiteuchus. As espécies foram subdivididas em seis grupos aqui propostos: A. amplus, A. supinatus, A. peruensis, A. tesselatus, A. marmoratus e A. mixtus. Oito novas espécies são descritas: A. amapensis sp. nov., A. beckerae sp. nov., $A$. doesburgi sp. nov., A. exiguus sp. nov., A. ledeburi sp. nov., A. marini sp. nov., A. melanicus sp. nov. and A. similis sp. nov. Nove espécies e uma subespécie são sinonimizadas. Antiteuchus varians Ruckes, 1964 é considerada sinônimo júnior de $A$. pallescens Stål, 1868; A. englemani Rolston, 1993 de A. amplus (Walker, 1867); A. tripterus limbativentris Ruckes, 1964 e A. minor Engleman, 1983 de A. tripterus (Fabricius, 1787); A. fuscus (Ruckes, 1959), A. piceus (Palisot de Beauvois, 1805), A. subgibbus Engleman, 1983, A. subimpunctatus Ruckes, 1964, A. unicolor (Westwood, 1837) e A. variolosus (Westwood, 1837) de A. mixtus (Fabricius, 1787). Antiteuchus tatei (Ruckes, 1958) é considerada species inquirenda. Empicoris marmoreus Spinola, 1837 é colocada em incertae sedis e tratada como species inquirenda. O macho de $A$. pictus, até agora desconhecido, é descrito. Chaves de identificação para os machos das espécies de Antiteuchus e para os grupos de espécies são apresentadas.

PALAVRA-CHAVE. Discocephalini; morfologia de genitália; sistemática.

Fabricius (1787) descreveu Cimex mixtus_e C. tripterus, ambos procedentes de Caiena, Guiana Francesa. Gmelin (1793) e Fabricius (1794) citaram C. mixtus e C. tipterus em suas listas de espécies. Fabricius (1803) descreveu Edessa guttatopunctata e E. sepulcralis, e transferiu para esse gênero as espécies C. mixtus e C.tripterus. Palisot de Beauvois (1808) descreveu Pentatoma picea, procedente de São Domingos, República Dominicana. Perty (1834) descreveu Pentatoma macraspis procedente de São Paulo, Brasil. Burmeister (1835) propôs o nome Dinocoris (ver Becker \& Grazia, 1985) e transferiu a espécie Pentatoma macraspis Perty para esse gênero. Hahn (1835) descreveu e ilustrou a espécie Dinocoris annulatus. Spinola (1837) descreveu Empicoris marmoreus e propôs o gênero Cataulax para a espécie nova C. macraspis.
Westwood (1837) descreveu Dinidor melanoleucus, D. tesselatus, D. variolosus, D. punctiger e D. unicolor, com base em material pertencente à coleção Hope. Amyot \& Serville (1843) transferiram Dinocoris macraspis (Perty) para o gênero Cataulax, que teve seu conceito redefinido. Assim, ficou configurada uma homonímia: Cataulax macraspis (Perty, 1834) e Cataulax macraspis Spinola, 1837. Entretanto, os autores consideraram erroneamente os táxons como sinônimos e válido o nome mais recente $C$. macraspis Spinola, 1837. As espécies $P$. picea Palisot de Beauvois e D. annulatus Hahn foram transferidas também para Cataulax. Herrich-Schäffer (1844) descreveu Empicoris renggerii do Paraguai. Erichson (1848) descreveu Cataulax marmoratus e C. apicalis, ambas da Guiana. Dallas (1851) em seu catálogo dos heterópteros do 
Museu Britânico descreveu Mecistorhinus para a espécie $M$. rufescens, e propôs Antiteuchus para A. variegatus, A. griseus e $A$. obscurus, sendo as duas últimas antecedidas por um ponto de interrogação (?). O autor propôs os dois gêneros em uma chave de identificação, mas apenas Mecistorhinus recebeu uma descrição mais detalhada antes da apresentação das espécies. Transferiu para Antiteuchus as seguintes espécies: D. punctiger Westwood, D. variolosus Westwood, D. melanoleucus Westwood e C. piceus (Palisot de Beauvois). Considerou, ainda, E. renggerii Herrich-Schäffer sinônimo júnior de $A$. melanoleucus, e $D$. unicolor sinônimo júnior de A. piceus. Transferiu Dinocoris annulatus Hahn para o gênero Antiteuchus, considerando como sinônimo júnior dessa espécie Cataulax macraspis, sensu Amyot e Serville (non Spinola). Nesse caso, o autor errou pois, reconhecendo que as espécies de Spinola e Perty não eram sinônimos, deveria desfazer a homonimia e considerar A. macraspis (Perty) sinônimo sênior de $A$. annulatus Hahn, por ser o nome mais antigo. Ao tratar do gênero Cataulax, persistiu no erro de Amyot e Serville considerando Pentatoma macraspis Perty sinônimo júnior de Cataulax macraspis Spinola. Fieber (1852) descreveu Macrothyreus annulicornis, procedente do Brasil. Stål (1855) descreveu A. luctuosus com base em um exemplar sem dados de coleta. Stål (1859) descreveu $A$. josephi e $A$. nigricornis, considerando essa espécie próxima de $A$. renggeri (Herrich-Schäffer). Stål (1860) descreveu o gênero monotípico Hypata para a espécie H. eximia do Brasil. Walker (1867) descreveu Discocephala ampla, D. signata e Cataulax centralis, e listou Macrothyreus annulicornis Fieber. Seguiu Dallas no conceito do gênero Antiteuchus, acrescentando as espécies descritas por Stål em 1855 e 1859. Stål (1867) incluiu em sua chave para os pentatomídeos os gêneros Antiteuchus e Mecistorhinus. Stål (1868), em seu trabalho sobre as espécies de hemípteros descritas por Fabricius, transferiu para Antiteuchus as espécies E. sepulcralis Fabricius, 1803, E. guttatopunctata Fabricius, 1803, E. tripterus (Fabricius, 1787) e E. mixtus (Fabricius, 1787); considerou A. griseus Dallas sinônimo júnior de $A$. guttatopunctatus, e Cataulax apicalis Erichson sinônimo júnior de $A$. tripterus. Ainda nesse trabalho descreveu A. pallescens, comparando-a com A. sepulcralis. Uhler (1869) descreveu Antiteuchus fraternus, procedente das proximidades do rio Napo (Perú). Stål (1872) reconheceu três gêneros: Cataulax Spinola, Dinocoris Burmeister e Macrothyreus Fieber. Reformulou o conceito de Dinocoris reconhecendo dois subgêneros, o nominal e Mecistorhinus Dallas, a partir de então com status novo. Ao tratar do gênero Cataulax desfez o erro de Amyot e Serville considerando como válidas as espécies de Perty e Spinola: $P$. macraspis Perty e $C$. macraspis Spinola. Ao tratar do gênero Dinocoris, incluiu no subgênero nominal duas espécies: $D$. (D.) macraspis (Perty) e D. (D.) variegatus (Dallas). No subgênero Mecistorhinus incluiu dez espécies, divididas em dois grupos: grupo "Mecistorhinus" com D. (M.) tripterus (Fabricius), D. (M.) sepulcralis (Fabricius), D. (M.) melanoleucus (Westwood), D. (M.) piceus (Palisot de Beauvois), D. (M.) guttatopunctatus (Fabricius), D. (M.) marmoreus (Spinola), D. (M.) obscurus
(Dallas) e D. (M.) josephi (Stål); e o grupo “Antiteuchus" com D. (M.) mixtus (Fabricius) e D. (M.) variolosus (Westwood). Considerou ainda $A$. luctuosus Stål sinônimo júnior de $D$. (M.) tripterus e A. nigricornis Stål sinônimo júnior de $D$. (M.) melanoleucus. $\mathrm{O}$ autor relacionou, sem indicar o subgênero, as espécies D. marmoratus (Erichson), D. tesselatus (Westwood), D. punctiger (Westwood), D. rufescens (Dallas) e $D$. unicolor (Westwood), retirado da sinonímia de $D$. (M.) piceus. Transferiu Hypata eximia Stål para o gênero Cataulax e considerou essa espécie sinônimo sênior de $C$. macraspis Spinola. Propôs, incorretamente, H. eximia Stål, em substituição a $C$. macraspis Spinola por julgar esse último nomen nudum. Finalmente, considerou o gênero Macrothyreus seguindo o conceito de Fieber. Uhler (1886) listou Dinocoris obscurus (Dallas) e D. tripterus (Fabricius) para o México e $D$. piceus (Palisot de Beauvois) para as Índias Ocidentais. Distant $(1880,1889)$ não seguiu a proposta de Stål para o gênero Dinocoris, pois considerou os subgêneros e Antiteuchus como sinônimos de Dinocoris, e descreveu D. complanatus do Panamá. Relacionou dentro deste gênero as espécies: $D$. tripterus (Fabricius), D. piceus (Palisot de Beauvois), D. obscurus (Dallas) e D. macraspis (Perty). Considerou, ainda, $D$. punctiger (Westwood) e C. centralis Walker sinônimos de D. tripterus, e $D$. unicolor (Westwood) sinônimo júnior de $D$. piceus. Lethierry \& Severin (1893) relacionaram em seu catálogo o gênero Discocephala, com a espécie D. ampla Walker, e o gênero Macrothyreus, com M. annulicornis Fieber. Seguiram a proposta de Stål para o gênero Dinocoris, mas desconsideraram os subgêneros, acrescentaram também a espécie nova e as sinonímias propostas por Distant (1880, 1889). Distant (1899) continuou seu longo trabalho de revisão do catálogo de Walker (1867-1868). Nesse trabalho o autor enfocou os discocefalíneos, indicando os gêneros e espécies que eram válidas e os que deveriam ser sinonimizados ou transferidos para outros táxons. Ele transferiu Discocephala ampla Walker para Dinocoris. Kirkaldy (1904) propôs o nome Grimgerda em substituição a Macrothyreus Fieber, 1852 por este estar pré-ocupado por outro táxon de Heteroptera, Macrothyreus Westwood, 1842. Kirkaldy (1909) em seu catálogo restabeleceu o status de gênero para Mecistorhinus e considerou Antiteuchus como subgênero deste, nomeou $A$. variolosus como espécie-tipo de Antiteuchus (não designado por Dallas, 1851, e portanto, vago até este trabalho). A composição desses dois subgêneros seguiu basicamente a estrutura dos grupos de espécies propostas por Stål (1872) para o subgênero Mecistorhinus (grupo "Antiteuchus" e grupo "Mecistorhinus"). Kirkaldy elevou os grupos de espécies de Stål a subgêneros, adicionando a Mecistorhinus as espécies $M$. complanatus Distant, $M$. rufescens Dallas e $D$. unicolor (Westwood), sendo essa última retirada da sinonímia de D. piceus (Palisot de Beauvois). No subgênero Antiteuchus foi adicionada apenas $M$. marmoreus (Spinola). O autor relacionou como insertae sedis $M$. amplus (Walker) e $M$. tesselatus (Westwood). Finalmente, Kirkaldy propôs o gênero Neodine para incluir as espécies D. macraspis (Perty) e $D$. variegatus (Dallas), consideradas por Stål como pertencentes 
ao subgênero Dinocoris, designando a primeira como espécietipo. Ainda nesse catálogo manteve annulicornis (Fieber) no gênero Grimgerda. Costa Lima (1940) levantou a possibilidade de Mecistorhinus variolosus (Westwood) ser uma "variedade" de $M$. mixtus (Fabricius) e identificou como $M$. mixtus exemplares de uma espécie desconhecida naquela época, $A$. radians Ruckes, 1964. Ruckes (1958) descreveu Neodine tatei com base em uma fêmea proveniente da Venezuela. Ruckes (1959) descreveu Mecistorhinus (M.) lineatus, M. (M.) panamensis e M. (M.) fuscus. Ruckes (1961) redescreveu Antiteuchus, elevando-o novamente a gênero, e Mecistorhinus. Considerou como pertencentes a Mecistorhinus as espécies M. rufescens Dallas (espécie-tipo), M. complanatus (Distant), M. josephi (Stål) e M. obscurus (Dallas). Considerou como pertencentes a Antiteuchus as espécies $A$. variolosus Dallas, A. melanoleucus (westwood), A. piceus (Palisot de Beauvois), A. mixtus (Fabricius), $A$. marmoreus (Spinola), A. panamensis (Ruckes), A. tripterus (Fabricius), A. sepulcralis (Fabricius), A. peruensis (descrita apenas em 1964), A. marmoratus (Erichson), A. tesselatus (Westwood), A. punctiger (Westwood), retirado da sinonímia de $A$. tripterus, e A. annulicornis (Fieber), transferido do gênero Gringerda. Neodine Kirkaldy foi considerado subgênero de Antiteuchus contendo as espécies A. macraspis (Perty), A. variegatus Dallas, 1851 e A.tatei (Ruckes). O autor propôs também o gênero Callostethus para espécie $D$. guttatopunctatus (Fabricius). Ruckes (1964) realizou um amplo estudo sobre Antiteuchus onde descreveu várias espécies novas e propôs, com base na morfologia externa, dois grupos de espécies para o subgênero nominal. O grupo "parallela" para incluir as espécies $A$. variolosus (Westwood), A. fuscus (Ruckes), A. piceus (Palisot de Beauvois), A. marmoreus (Spinola), A. mixtus (Fabricius), A. panamensis (Ruckes), $A$. sepulcralis (Fabricius), A. tripterus (Fabricius), $A$. melanoleucus (Westwood), e as espécies novas $A$. radians, A. subimpunctatus, $A$. nigricans, $A$. fulvescens, $A$. pictus, $A$. costaricensis, A. maculosus e a subespécie $A$. tripterus limbativentris proposta para exemplares provenientes da Colômbia. O grupo "incurvaria" para incluir as espécies $A$. amplus (Walker), A. marmoratus (Erichson), A. tesselatus (Westwood), A. pallescens Stål e as novas espécies $A$. peruensis (descrita formalmente nesse trabalho), A. nebulosus, A. punctissimus, $A$. confinium, $A$. varians, $A$. guianensis, $A$. cuspidatus, $A$. bartletti e $A$. mimeticus. $\mathrm{O}$ autor considerou ainda $A$. annulicornis (Fieber) sinônimo júnior de $A$. tesselatus e A. punctiger (Westwood) sinônimo júnior de $A$. tripterus. Ruckes mencionou que a ilustração de M. mixtus (Fabricius) encontrada em Costa Lima (1940:54) tratava-se, de fato, da nova espécie $A$. (A.) radians, e que a ilustração de $A$. tripterus (Fabricius) encontrada em Distant (1880: pl. 5, fig. 3) tratavase na realidade da nova espécie $A$. costaricensis; Ruckes também se equivocou pois os exemplares de Distant são, de fato, A. innocens Engleman, 1983. A composição do subgênero Neodine seguiu a proposição feita por Ruckes (1961). Becker \& Grazia-Vieira (1971) incluíram em sua lista dos Pentatomoidea da Venezuela $A$. (A.) fuscus (Ruckes), A. (A.) sepulcralis
(Fabricius), A. (A.) tripterus tripterus (Fabricius), A. (A.) variolosus (Westwood) e $A$. (N.) macraspis (Perty). Engleman (1976) descreveu A. (A.). rolstoni do Perú e incluiu essa espécie no grupo "incurvaria". Froeschner (1979) considerou $A$. fraternus Uhler sinônimo júnior de Callostethus guttatopunctatus (Fabricius). Froeschner (1981) registrou $A$. maculosus Ruckes e A. marmoreus (Spinola) para o Equador. Engleman \& Rolston (1983) descreveram oito espécies novas de Antiteuchus. No subgênero Neodine foi descrita A. schuhi. No subgênero nominal, grupo "parallela" foram descritos $A$. subgibbus, $A$. minor, $A$. innocens; para o grupo "incurvaria" foram descritas $A$. ratcliffei, $A$. graziae, $A$. supinatus e $A$. geometricus. O autor descreveu ainda dois machos desconhecidos até então de $A$. variegatus Dallas e $A$. variolosus (Westwood); sendo a primeira espécie pertencente ao subgênero Neodine e a segunda no grupo "parallela" do subgênero nominal. Rolston (1991) descreveu A. ruckesi, incluindo essa espécie no grupo "incurvaria". Rolston (1993) descreveu três espécies novas: A. rufitarsus, A. englemani e A. rideri, incluídas no grupo "incurvaria", apresentou uma chave para identificação dos machos desse mesmo grupo e designou lectótipos e paralectótipos para A. sepulcralis (Fabricius) e A. pallescens Stål.

\section{MATERIAL E MÉTODOS}

Utilizou-se, neste trabalho, material das coleções relacionadas a seguir. AMNH- American Museum of Natural History, New York, EUA. BMNH- The Natural History Museum, Londres, Inglaterra. CASC- California Academy of Sciences, San Francisco, California, EUA. DZUP- Universidade Federal do Paraná, Curitiba, Paraná, Brasil. FIOC- Instituto Oswaldo Cruz, Rio de Janeiro, Rio de Janeiro, Brasil. IBSPInstituto Biológico de São Paulo, São Paulo, Brasil. IMLAFundacion Miguel Lillo, S. Miguel de Tucumán, Tucumán, Argentina. INPA- Instituto Nacional de Pesquisas da Amazônia, Manaus, Amazonas, Brasil. IZAV- Museo del Instituto de Zoologia Agrícola, Maracay, Venezuela. MCZN- Fundação Zoobotânica do RS, Porto Alegre, Rio Grande do Sul, Brasil. MGAP- Museu Anchieta, Porto Alegre, Rio Grande do Sul, Brasil. MLPA- Museu de La Plata, La Plata, Argentina. MNHNMuseum National d'Histoire Naturelle, Paris França. MNRJMuseu Nacional, Universidade Federal do Rio de Janeiro, Rio de Janeiro, Brasil. MPEG- Museu Paraense Emílio Goeldi, Belém, Pará, Brasil. MZSP- Museu de Zoologia da USP, São Paulo, Brasil. NHRS- Naturhistoriska Riksmuseet, Estocolmo, Suécia. NMNH - Smithsonian Institution, National Museum of Natural History, Washington, D. C., EUA. ORST- Office de la Recherche Scientifique et Technique d'Óutre-Mer, Bondy, França. OXUM- Hope Entomological Collections-Oxford University, Oxford, Inglaterra. RMNH- Nationaal Natuurhistorisch Museum, Naturalis. Leiden, Holanda. SEMCSnow Entomological Collection, Lawrence, Kansas, EUA. UFAM- Laboratório de Zoologia, Universidade Federal do Amazonas, Manaus, Amazonas. UFRG- Departamento de Zoologia, Universidade Federal do Rio Grande do sul, Porto 
Alegre, Rio Grande do Sul, Brasil. UFRRJ- Universidade Federal Rural do Rio de Janeiro, Seropédica, Rio de Janeiro, Rio de Janeiro, Brasil. UYIC- Instituto de Biologia, Montevidéu, Uruguai. ZMHB- Museum für Naturkunde, Humboldt Universität zu Berlin, Berlin, Alemanha. ZMUC- Zoological Museum, University of Copenhagen, Copenhague, Dinamarca. ZSMC- Zoologische Staatssammlung München, Munique, Alemanha.

Foram examinados os exemplares-tipo e/ou parátipos de todas as espécies, exceto $A$. macraspis (Perty), A. marmoreus (Spinola), A. piceus (Palisot de Beauvois) e A. tatei (Ruckes) que não foram localizados nas coleções onde deveriam estar depositados.

O número total de exemplares analisados por espécie foi muito variável. Algumas espécies tiveram apenas o tipo ou poucos exemplares estudados. Por outro lado, algumas espécies (por exemplo, A. mixtus e A. tripterus) tiveram milhares de exemplares examinados. De outras espécies foram analisados dezenas ou centenas de indivíduos. Para não aumentar o texto com dados incompletos ou pouco informativos, optou-se por não apresentar os nomes dos coletores nem as datas de coleta. Apenas os dados geográficos são apresentados. Estes dados incluem também os levantados da literatura. Dados completos de coleta são apresentados somente para as espécies descritas neste artigo.

Parte dos desenhos são contornos cobertos com nanquim e parte feitos a lápis para ressaltar detalhes e profundidade das estruturas. Uma espécie, de cada grupo de espécies, foi selecionada e todos os desenhos de pigóforo e parâmero foram feitos a lápis para ilustrar o padrão dos diferentes grupos.

São apresentadas apenas duas medidas, comprimento total e largura abdominal, com o objetivo de transmitir uma idéia do tamanho dos exemplares. O "n" utilizado nas medidas indica o número total de exemplares da amostra ou dez dentre os menores machos e dez dentre as maiores fêmeas escolhidos previamente da amostra de estudo. As medidas estão expressas em milímetros. A terminologia da genitália segue Dupuis (1970).

\section{RESULTADOS}

Este trabalho apresenta uma estrutura taxonômica para Antiteuchus bastante distinta daquela proposta por Ruckes (1964). Os subgêneros são abandonados e Neodine considerado sinônimo de Antiteuchus. As espécies anteriormente incluídas nestes subgêneros são distribuídas em seis grupos de espécies. Tais modificações são fruto de uma análise cladística do gênero que está sendo preparada para publicação. As fêmeas de uma grande parte das espécies apresentam dimorfismo sexual, sendo mais claras e apresentando um padrão de coloração variegado, enquanto os machos são uniformemente escuros. Esta variação na coloração associada a falta de características diagnósticas na morfologia externa, impede que as fêmeas da maioria das espécies sejam identificadas com segurança.

\section{Antiteuchus Dallas, 1851}

Antiteuchus Dallas, 1851: 152, 163. Stål, 1867: 501; Stål, 1868: 18; Walker, 1867: 198; Ruckes, 1961: 151, figs. 2-4; Ruckes, 1964: 5859.

Dinocoris; Stål (part.), 1872: 7; Lethierry \& Severin, 1893: 85; Distant, 1880: 45-46

Macrothyreus Fieber, 1852: 34; Lethierry \& Severin, 1893: 87; Walker, 1867: 191

Grimgerda Kirkaldy, 1904: 280; Kirkaldy, 1909: 218.

Neodine Kirkaldy, 1909: 218. SIN. NOV.

Espécie-tipo: Dinidor variolosus Westwood, sinônimo júnior de $A$. mixtus (Fabricius).

Diagnose: Corpo arredondado, brilhante e liso. Machos escuros e fêmeas claras, geralmente variegadas com manchas claras e escuras. Cabeça quase tão larga quanto longa antes dos olhos, margens sinuadas, subparalelas e planas com ápice arredondado e íntegro. Rostro atingindo o segmento abdominal V. Hemiélitro dos machos com a margem posterior da parte membranosa arredondada. Conexivo exposto e geralmente com áreas claras e escuras alternadas. Machos apresentando processo mediano dorsal no urotergito VII. Pigóforo com ângulos póstero-laterais semi-articulados; bordo dorsal com uma escavação que varia em profundidade; bordo ventral baixo e não fundido aos ângulos póstero-laterais. Cabeça do parâmero pequena e formada basicamente por quatro lobos. Segmento X parcialmente membranoso dorsalmente.

Redescrição: Cabeça ovalada, margens anteoculares sinuosas, subparalelas e não refletidas. Olhos bem desenvolvidos e protrusos. Ocelos na mesma linha da margem posterior dos olhos. Jugas mais longas que o clípeo e tocandose adiante deste, tornando arredondado o ápice da cabeça. Margens das jugas íntegras, margem externa escura. Coloração da cabeça igual ao da superfície dorsal, pontuação mais esparsa que a do corpo e interligada ou não por faixas mais escuras. Antena com 5 segmentos normalmente atingindo ou passando o meio do escutelo. Antenas recobertas por sétulas, pêlos de comprimento menor que o diâmetro do segmento e decumbentes. Tubérculo antenífero sem um pequeno dente. Segmento I não atingindo o ápice da cabeça. Búcula pouco elevada, subparalela, uniforme em altura e evanescente na base. Rostro atingindo no máximo o segmento abdominal V, com um pequeno esclerito intercalar entre os segmentos I e II. Segmento I atingindo as procoxas, II levemente arqueado, atingindo as mesocoxas e um pouco mais curto que III e IV juntos; IV mais curto que III. Pronoto apresentando um colar sobre a região de encaixe da cabeça. Pontuação do colar e das cicatrizes do pronoto menor que a do restante do corpo. Área evaporatória mais escura que o corpo, fosca, rugosa, com superfície áspera e estendendo-se sobre o mesoepímero e metaepisterno. Peritrema ostiolar digitiforme, reto e truncado no ápice; continuando esta estrutura existe uma longa prega fina, plana e lisa dorsalmente, inclinada anteriormente, quase atingindo a margem anterior da mesopleura. Mesosterno túmido, sulcado medianamente e com uma carena longitudinal baixa no $1 / 4$ posterior. Metasterno hexagonal, pouco mais longo que largo, plano, apresentando uma carena baixa, longitudinal e mediana. 
Meso e metacoxas eqüidistantes entre si. Hemiélitro com ápice agudo. Membrana do hemiélitro hialina, escura, margem posterior arredondada, com 6-8 veias e avançando na lateral externa do cório. Abdome sem pontuação com exceção do conexivo. Sulco abdominal mediano, largo, raso e sem pontuação. Margem anterior do esternito VII produzido anteriormente em um ângulo agudo que quase divide o segmento VI. Urotergito VII (VII) margeado por uma membrana (me) que une os conexivos VII (co) e apresentando um processo mediano (pm) dirigido posteriormente (fig. 4), este possui formas e graus de desenvolvimento distintos entre as espécies.

Pigóforo (figs. 5-7) globoso e de contorno retangular devido ao grande desenvolvimento dos ângulos póstero-laterais do pigóforo (apl). Bordo dorsal (bd) apresentando uma escavação em "U" com profundidade variável coberta por uma membrana. Bordo dorsal projetado dorsalmente junto à base do segmento $\mathrm{X}$ formando $1+1$ abas (pb) localizadas uma de cada lado deste (figs. 5, 7). Látero-dorsalmente ocorre um processo (pld) com diferentes graus de desenvolvimento, apresentando textura distinta do restante do pigóforo, recoberto por pêlos e localizado junto a base do ângulo póstero-lateral do pigóforo, podendo ou não atingi-lo (figs. 5, 7). Ângulos póstero-laterais do pigóforo livres, fundidos com o bordo ventral apenas na base, e com diferentes formas e graus de desenvolvimento (figs. 5-7). Bordo ventral (bv) com uma concavidade mediana de tamanho variável (fig. 22) e não projetado dorsalmente. Parâmero (pa) formado basicamente por quatro lobos que podem estar fundidos ou divididos em diferentes graus. Segmento $\mathrm{X}(\mathrm{x})$ com diferentes formas e parcialmente membranoso na superfície dorsal (fig. 5, 7).

O falo (fig. 1) apresenta uma faloteca (ph) ovalada e levemente achatada lateralmente. Margem dorsal reta com uma pequena área intumescida mediana. Região distal com uma pequena abertura quase totalmente ocupada pela vésica. Conjuntiva (cj) ausente ou reduzida a uma pequena aba membranosa localizada ao lado da vésica. Vésica (v) com ou sem um processo dorsal em forma de escudo (pv). Este processo pode variar desde uma pequena estrutura semimembranosa até uma placa desenvolvida, convexa e esclerotizada. Ductus seminis distalis (dsd) pelo menos duas vezes mais longo que a faloteca, podendo atingir mais de seis vezes este comprimento nos espécimes do grupo A. amplus. O tamanho do processo dorsal da vésica e o comprimento do ductus seminis distalis podem apresentar variação intraespecífica.

As placas (fig. 2) e vias genitais ectodérmicas (fig. 3), nas fêmeas de Antiteuchus não apresentam variações interespecíficas consideráveis. Gonocoxitos 8 (gc8) amplos, maiores que as outras placas, contorno arredondado ou subretangular, planos ou levemente convexos e com muitos sulcos na superfície dorsal; bordos suturais retilineos. Laterotergitos 8 (la8) curtos e subtriangulares, espiráculos reduzidos. Gonocoxitos 9 (gc9) subtrapezoidal e com braços curtos partindo de seus ângulos laterais. Esta placa fica recoberta pelos gonocoxitos 8 , sendo observável apenas em exemplares

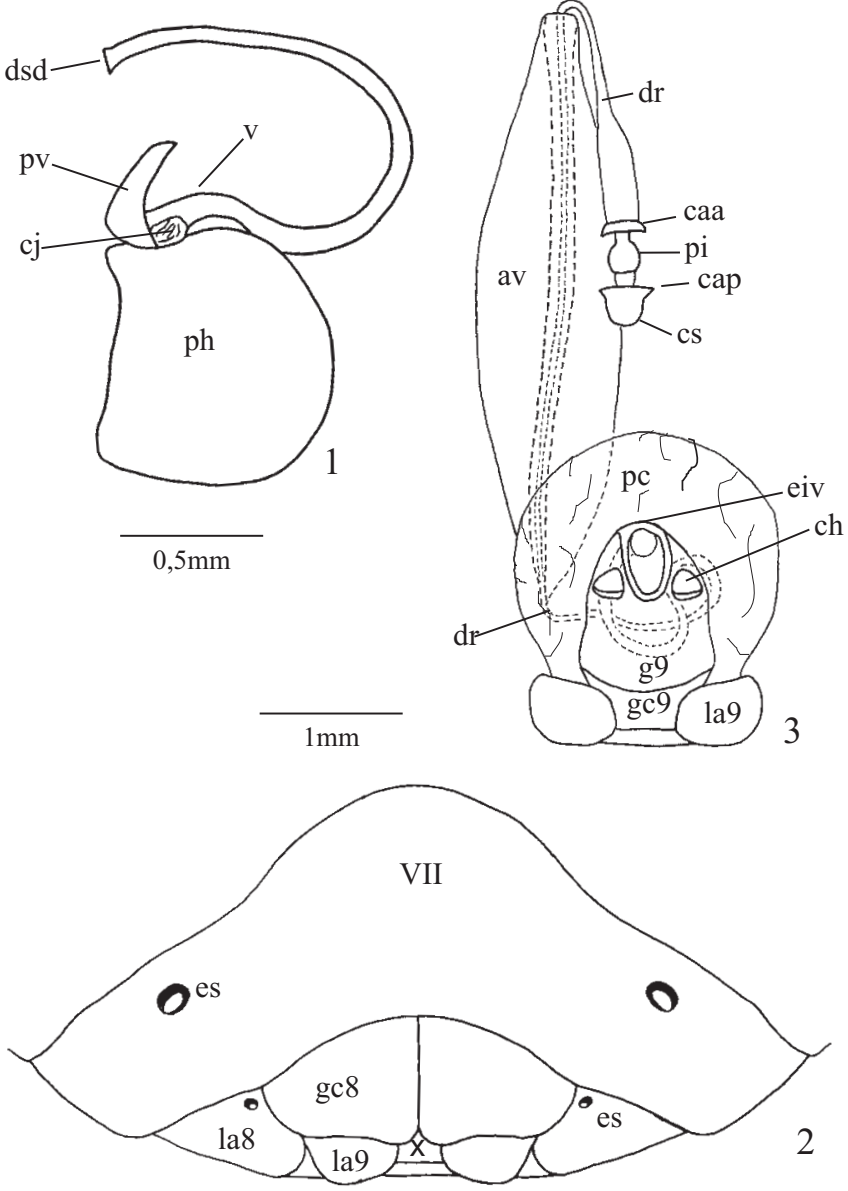

Figs. 1-3. Genitália interna de ambos os sexos e placas genitais de $A$. mixtus. 1, Falo em vista lateral, sem o aparelho articular; 2, Placas genitais; 3, Placas genitais e vias genitais ectodérmicas; vista ventral. (av- área vesicular do ducto do receptáculo; caa- crista anular anterior; cap- crista anular posterior; ch- chitinellipsen; cj- conjuntiva; cs- cápsula seminal; dr- ducto do receptáculo; dsd-ductus seminis distalis; eivespessamento da íntima vaginal; es- espiráculo; g9- gonapófise 9; gc8gonocoxito 8; gc9- gonocoxito 9; la8- laterotergito 8; la9- laterotergito 9; pc- pars comunis; ph- faloteca; pi- pars intermedialis; pv- processo da vésica; v-vésica; VII- sétimo segmento abdominal; X- décimo segmento abdominal).

dissecados (fig. 3). Laterotergitos 9 (la9) ovalados ou subretangulares, atingindo ou ultrapassando a banda que une os laterotergitos 8 (figs. 2-3). Gonapófises 9 (g9) ampla e longa; chitinellipsen (ch) ovaladas, espessas e colocadas junto ao espessamento da íntima vaginal (eiv). Esta estrutura, por sua vez, é espessa e ovalada, com a margem ventral projetada internamente, formando uma aba (fig. 3). Ducto do receptáculo seminal (dr) curto, região posterior à área vesicular mais longa que a região anterior a esta área (fig. 3). Área vesicular (av) longa, ocupando uma grande parte do ducto do receptáculo, canal mais interno com diâmetro constante e o intermediário aumentando de diâmetro em direção à região posterior. Região posterior do ducto do receptáculo alargando-se em direção à cápsula seminal. Cristas anulares (caa e cap) dirigidas uma para outra. Pars intermedialis (pi) com 3/4 anteriores ocupados 
por um cálice esclerotizado, 1/4 posterior membranoso (fig. 3). Cápsula seminal (cs) globosa, possuindo ou não projeções espiniformes ( 1 ou 2 ) dirigidas para a base das cristas anulares.

Comentários: Este gênero apresenta grandes semelhanças com outros gêneros de Discocephalinae. Entre os gêneros que podem ser confundidos com Antiteuchus é possível citar Callostethus Ruckes, 1961, cuja única espécie, $C$. guttatopunctatus, fez parte de Antiteuchus por muito tempo, Cataulax Spinola, 1837, Patronatus Ruckes, 1965, Ablaptus Stål, 1864, Mecistorhinus Dallas, 1851 e Parantiteuchus Ruckes, 1962. Mecistorhinus sempre foi considerado "próximo" de Antiteuchus pelos sistematas que trabalharam com estes gêneros, mas uma comparação direta entre estes dois gêneros revela características muito distintas. Mecistorhinus, por exemplo, possui a proporção entre largura e comprimento da cabeça, bem como a do corpo, diferentes de Antiteuchus; seu rostro é bastante longo, atingindo o terço distal do abdome enquanto em Antiteuchus ele atinge o terço proximal do abdome; a forma e estrutura dos pigóforos são diferentes, entre outras características. Dos gêneros relacionados acima, apenas Callostethus compartilha características exclusivas com Antiteuchus: presença de um processo mediano no urotergito VII bem desenvolvido e segmento X parcialmente membranoso na superfície dorsal. Somente uma análise cladística dos gêneros de Discocephalinae poderá esclarecer a posição de Antiteuchus e suas relações de parentesco.

Distribuição: México, Belize, guatemala, república dominicana, Costa Rica, Panamá, Colômbia, Venezuela, trinidad e tobago, Guiana, Suriname, Guiana Francesa, Brasil, Equador, Perú, Bolívia, Paraguai e Argentina.

\section{Chave de identificação para os machos dos grupos de espécies de Antiteuchus.}

1. Margem do urotergito VII com membrana completa e larga (pode estar dobrada ventralmente no grupo amplus), e não margeada por pêlos. Bordo dorsal do pigóforo com uma escavação tão ou mais profunda que larga (figs. 4-5, 62-63) 2

Margem do urotergito VII com uma membrana completa e estreita, margeada por pêlos. Bordo dorsal do pigóforo com uma escavação rasa, nitidamente mais larga que profunda (figs. 196-197, 210-211) .......... grupo A. mixtus

2(1). Parâmero com o lobo dorsal muito grande em relação aos demais, delgado, projetado posteriormente e apresentando uma série de carenas altas na margem (figs. 31-33, 38-40) ......................... grupo A. amplus

Parâmero sem grandes variações entre o tamanho dos lobos; lobo dorsal geralmente projetado dorsalmente, podendo curvar-se posteriormente; carenas ausentes ou com cristas baixas que parecem um enrugamento da parede do lobo (figs. 8-10, 66-68) ... 3

3(2). Ângulos póstero-laterais do pigóforo achatados lateralmente, retos ou curvados, divergentes em sua metade anterior e sem uma prega na face dorsal. Segmento X grande, ocupando a maior parte da taça genital (figs. 13-14, 21-22) ........... grupo A. supinatus

Ângulos póstero-laterais do pigóforo não achatados, retos ou fortemente curvados, convergentes ou paralelos e com uma prega na face dorsal. Segmento $\mathrm{X}$ pequeno em relação à taça genital (figs. 63-64, 183184)

4(3). Ângulos póstero-laterais do pigóforo curvados e convergentes. Lobo dorsal do parâmero com um número variável de pequenas cristas que mais parecem um enrugamento da parede lateral do lobo (figs. 66, 151) grupo $A$. peruensis

Ângulos póstero-laterais do pigóforo retos e paralelos. Face dorsal do parâmero sem carenas ou cristas (figs. $162,165,183,186)$ 5

5(4). Superfície ventral do pigóforo com $1+1$ grandes áreas intumescidas próximas aos ângulos póstero-laterais. Lobo dorsal do parâmero muito desenvolvido e projetado ventralmente, ocultando o lobo lateral interno em vista posterior (figs. 163, 165-167, 179-181) grupo $A$. tesselatus

Superfície ventral do pigóforo sem áreas intumescidas. Lobo dorsal do parâmero curto e curvado lateralmente (figs. 184, 186-188) grupo A. marmoratus

\section{Grupo A. supinatus}

(Figs. 4-26, 302)

Corpo achatado dorso-ventralmente, coloração variegada e brilhante, os machos normalmente são mais escuros que as fêmeas. Pontuação densa distribuída em linhas sinuosas e geralmente transversais ou formando manchas irregulares, principalmente sobre o hemiélitro e escutelo; os pontos são recobertos por faixas castanhas a castanho-escuras.

Jugas com as margens externas negras. Hemiélitro com ápice atingindo a metade posterior do conexivo VII, pontuação irregularmente distribuída. Escutelo com ápice arredondado e atingindo a metade distal do urotergito VII. Ventralmente o corpo é amarelo com manchas castanhas a castanho-escuras. Área evaporatória castanha. Ruga ostiolar amarelo-pálida. Mesopleura com um pequeno calo amarelo-pálido. Metapleura com um grande calo amarelo-pálido junto a margem lateral. Coxas e trocânteres amarelos e imaculados. Fêmures e tíbias amarelas recobertas por manchas castanhas a castanhoescuras. Tíbias com pêlos mais curtos que o diâmetro do segmento. Conexivo exposto, áreas intersegmentares escuras separadas por áreas claras; pontuação esparsa. Coloração dorsal do abdome castanho-escura. Região calosa interna a cada espiráculo amarelo-pálido. Margem lateral e ângulo póstero-lateral, de cada segmento, escuros. Uma linha imaginária tangente à margem posterior do conexivo VII não secciona o ângulo póstero-lateral do urotergito VII (figs. 4, 11, 
19). Urotergito VII com um par de áreas membranosas elípticas e com coloração diferenciada do restante da membrana do tergito, laterais ao processo mediano. Margem posterior do urotergito VII sem um processo espessado. Processo mediano do urotergito VII sem uma lígula membranosa na extremidade posterior. Membrana bem desenvolvida, sem pêlos e estendendo-se por toda margem posterior do segmento.

Pigóforo amarelo-escuro com um tufo de pêlos longos na lateral, junto ao ângulo póstero-lateral do pigóforo. Ângulo póstero-lateral do pigóforo ogival, em vista lateral, achatado, sem prega transversal sobre a face dorsal e sem carena na margem ventral interna; ápice intumescido (figs. 21, 23). Ângulo mais longo que a parte esclerotizada do segmento $\mathrm{X}$ e implantado obliquamente em relação ao plano longitudinal do pigóforo. Processo látero-dorsal muito desenvolvido, arredondado e parcialmente fundido com $1 / 3$ basal do ângulo póstero-lateral do pigóforo (figs. 7, 15, 23). Bordo dorsal sem áreas intumescidas laterais ao segmento X. Escavação do bordo dorsal tão profunda quanto larga (figs. 5, 13, 21). Diafragma sem processos membranosos. Superfície ventral não apresenta projeções ou tufos de pêlos característicos.

Parâmero apresentando a cabeça perpendicular ao seu eixo longitudinal (figs. 8-9, 17-18, 25-26). Margem lateral interna do lobo dorsal sem carenas.

Segmento X semicilíndrico, recoberto por pêlos esparsos na face posterior, tubérculos e margem ventral, sem áreas dorsolaterais intumescidas (figs. 5, 13, 21). Tubérculos (tx) implantados transversalmente sobre o segmento X (fig. 5). Face posterior com carenas laterais (cx) convergentes e sem uma área intumescida na base (fig. 5). Membrana dorsal terminando adiante dos tubérculos.

Comentários: Este grupo de espécies é composto por $A$. supinatus, A. geometricus e A. exiguus, facilmente reconhecidas pela presença de uma área elíptica e membranosa sobre o urotergito VII, junto à margem lateral; pelo ângulo póstero-lateral do pigóforo achatado, com ápice intumescido, presença de um tubérculo na margem interna da face ventral e ausência de uma prega sobre a face dorsal; pelo processo látero-dorsal muito desenvolvido e projetado sobre o ângulo póstero-lateral do pigóforo, com o qual funde-se parcialmente; e pelo segmento $\mathrm{X}$ muito grande em relação à taça genital $\mathrm{e}$ apresentando tubérculos implantados transversalmente.

\section{Chave de identificação para os machos das espécies do grupo}

\section{A. supinatus.}

1. Urosternito VII com um processo retangular mediano projetado posteriormente. Ápice do processo mediano do urotergito VII dilatado (figs. 11-12, 19-20)

Urosternito VII sem este processo. Ápice do processo mediano do urotergito VII não dilatado (fig. 4)

A. supinatus

2(1). Ângulo póstero-lateral do pigóforo reto e com um tubérculo no $1 / 3$ mediano. Segmento $X$ com uma grande área intumescida ao longo de suas laterais (figs. 11, 13, 14) A. geometricus

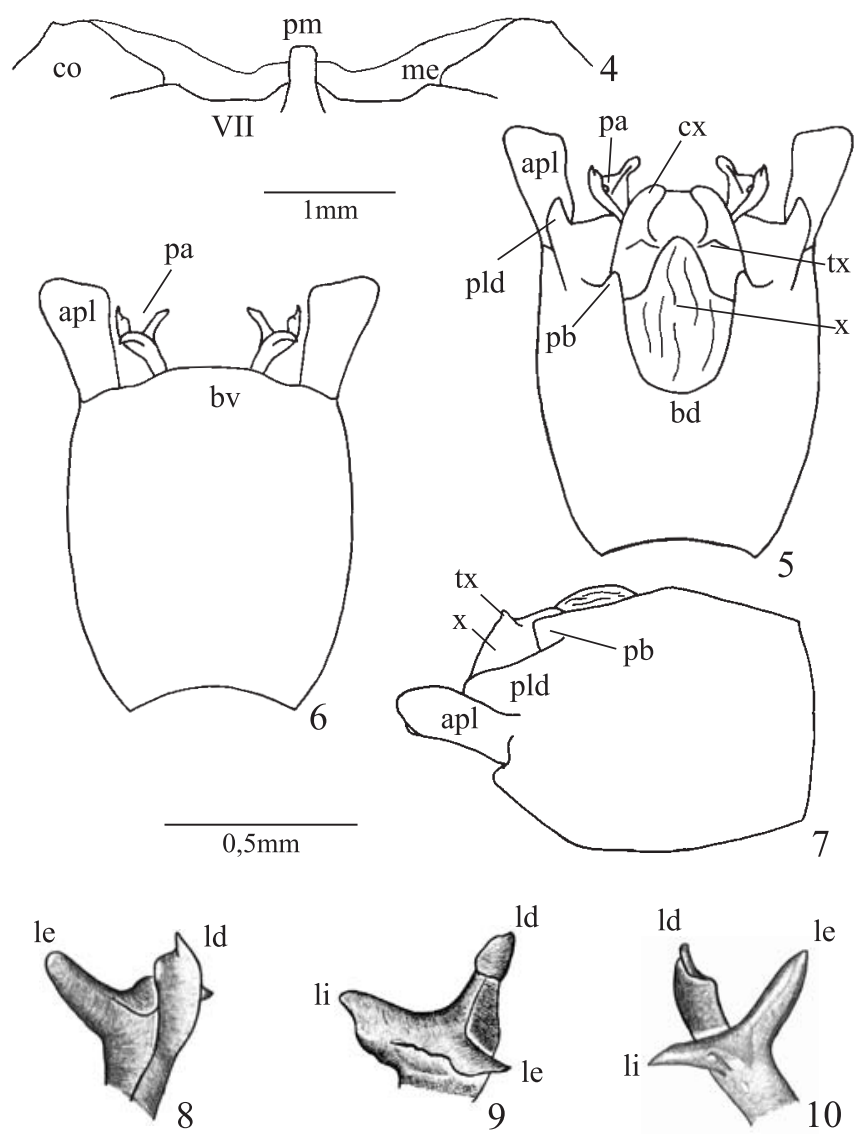

Figs. 4-10. Antiteuchus supinatus. 4, Processo mediano do tergito VII; 5-7, Pigóforo em vistas dorsal, ventral e lateral, respectivamente; 8-10, Parâmero em vistas dorsal, posterior e ventral, respectivamente. (aplângulo póstero-lateral do pigóforo; bd- bordo dorsal; bv- bordo ventral; co- conexivo do segmento VII; cx- carena lateral do segmento X; ld- lobo dorsal; le- lobo lateral externo; li- lobo lateral interno; lv- lobo ventral; memembrana do tergito VII; pa- parâmero; pb- projeções do bordo dorsal; pld- processo látero-dorsal; pm- processo mediano do tergito VII; txtubérculo do segmento X; VII- tergito VII; $\mathrm{x}$ - segmento X).

Ângulo póstero-lateral do pigóforo curvado internamente e com um tubérculo junto ao ápice. Segmento X sem áreas intumescidas nas laterais (fig. 21) A. exiguus sp. nov.

Antiteuchus supinatus Engleman, 1983

(Figs. 4-10, 302)

Antiteuchus (Antiteuchus) supinatus Engleman, 1983 (in Engleman \& Rolston, 1983): 187-188, figs. 16, 21; Rolston, 1993: 109 (chave), 122 .

Medidas ( $\mathrm{n}=2)$ : comprimento total- 12-12,8; largura total7,9-8,2.

Segmentos antenais I-IV variegados de castanho-escuro com áreas negras e algumas manchas amarelas. Segmento V desconhecido. Segmentos em ordem crescente de comprimento: I; II; III; IV. 
Urotergito VII sem impressões ou elevações laterais ao processo mediano. Processo mediano bem desenvolvido, parte livre retangular, curta, estreita, levemente convexa transversalmente, reta e dirigida póstero-ventralmente; ápice com a margem posterior inteira e curvada ventralmente (fig. 4). Membrana sem áreas esclerotizadas junto à margem posterior de cada conexivo VII. Margem posterior do processo praticamente coincidindo com o final da membrana. Urosternito VII sem um processo retangular na margem posterior.

Pigóforo. Projeções do bordo dorsal, laterais ao segmento $\mathrm{X}$, dentiformes e não projetadas em direção aos tubérculos deste (fig. 5). Bordo ventral trapezoidal, baixo, largo, côncavo transversalmente, margem superior convexa, dobrada dorsalmente e mais larga que a extremidade do segmento $\mathrm{X}$ (fig. 6). Superfície ventral, logo abaixo do bordo ventral, apresentando uma grande área escavada longitudinal e mediana, recoberta por pêlos esparsos. Ângulo póstero-lateral do pigóforo quase 3,5 vezes mais longo que largo, em vista lateral (fig. 7). Ângulos achatados, retos, divergentes e com um tubérculo junto ao ápice. Face interna levemente convexa, ápice com muitas manchas castanho-escuras. Face externa plana com pontos rasos interligados por faixas castanho-claras e apresentando muitos sulcos longitudinais; margem interna castanho-escura.

Cabeça do parâmero composta por 4 lobos visíveis (figs. 8-10). Dorsal longo, estreito, triangular e aparentando ter o ápice dobrado lateralmente, tal impressão é causada pela carena dorsal alta que termina sobre o lobo lateral. Lobo lateral interno grande, achatado, espatular e dirigido pósterolateralmente. Lobo lateral externo curto, reto e lingüiforme ou subquadrado. Lobo ventral reduzido, papiliforme ou triangular e localizado junto ao lobo lateral externo.

Segmento $X$ (figs. 5, 7) sem áreas túmidas ventrais. Tubérculos pouco desenvolvidos, triangulares, em vista posterior, e dirigidos dorsalmente. Face posterior muito inclinada, quase perpendicular ao plano frontal do pigóforo; carenas laterais muito desenvolvidas; crista mediana elevada no $1 / 3$ ventral, nos $2 / 3$ superiores ela é substituída por uma área convexa e estreita.

Holótipo macho. "Trop. Research Station New York Zool. Society no", "Brit. Mus. 1954-631" (BMNH). Examinado. Engleman (in Engleman \& Rolston, 1983) afirma que, segundo o livro de registro do Museu Britânico, o exemplar foi coletado por Mrs. M. D. Brindley nee Haviland; ela coletou em Kartabu e ao longo dos rios Demara e Berbice, Guiana, entre junho e setembro de 1922.

Distribuição: Guiana. Brasil, Amazonas: Manaus.

Comentários: Espécie é conhecida pelo holótipo e por outro exemplar da UFRG. A. supinatus é facilmente reconhecida pelo processo mediano do urotergito VII com as margens paralelas e ápice curvado ventralmente; pelo ângulo pósterolateral do pigóforo quase 3,5 vezes mais longo que largo; pelo lobo ventral do parâmero reduzido e localizado junto ao lobo lateral externo; pelos tubérculos do segmento $\mathrm{X}$ triangulares, em vista posterior, pequenos e dirigidos dorsalmente. $A$. supinatus e A. geometricus possuem algumas semelhanças
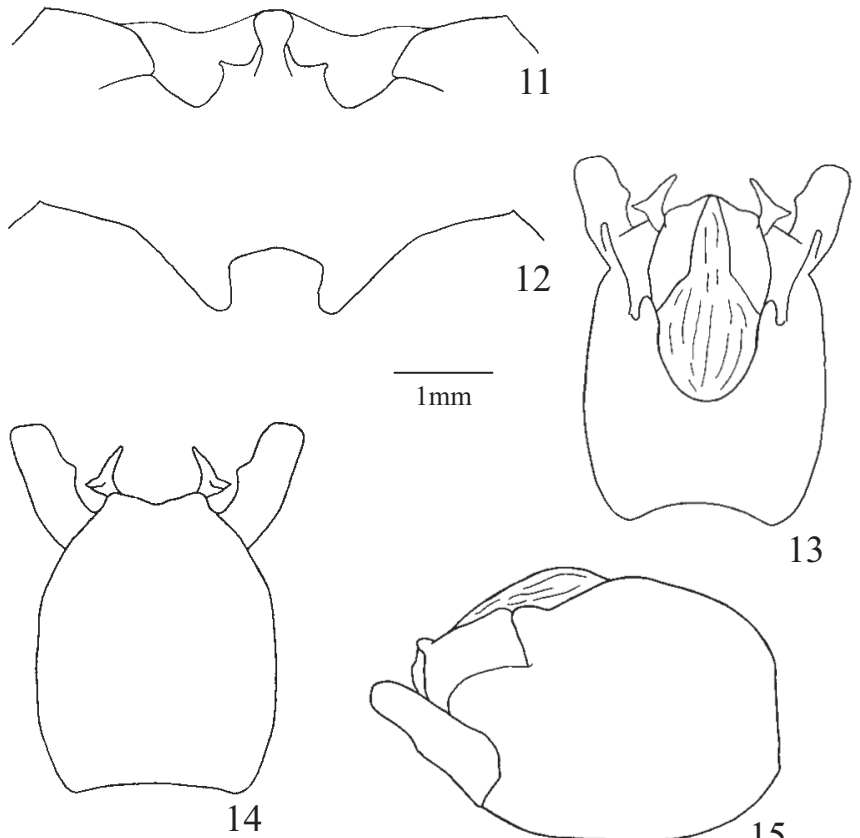

13
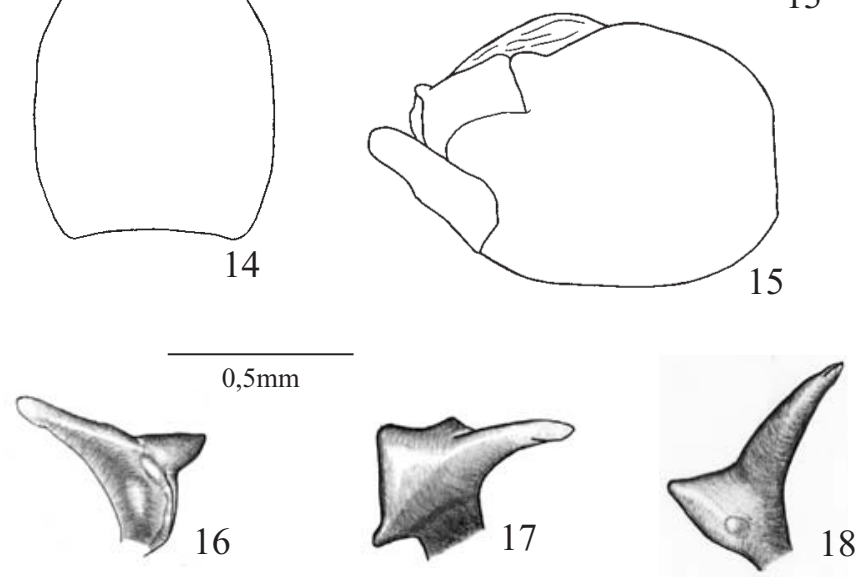

Figs. 11-18. Antiteuchus geometricus. 11, Processo mediano do tergito VII; 12, Processo mediano do urosternito VII; 13-15, Pigóforo em vistas dorsal, ventral e lateral, respectivamente; 16-18, Parâmero em vistas dorsal, posterior e ventral, respectivamente.

importantes como o bordo ventral convexo transversalmente e dobrado dorsalmente e a forma reta de cada ângulo pósterolateral do pigóforo. A. supinatus e A. exiguus têm como característica comum mais importante a posição subapical do tubérculo de cada ângulo póstero-lateral do pigóforo.

Antiteuchus geometricus Engleman, 1983 (Figs. 11-18, 302)

Antiteuchus (Antiteuchus) geometricus Engleman, 1983 (in Engleman \& Rolston, 1983): 188, figs. 14, 18-19; Rolston, 1993: 109 (chave), 118 , figs. $36-40$.

Medidas ( $\mathrm{n}=2)$ : comprimento total- 12,6-13,5; largura total$8,2-8,7$.

Segmentos antenais I e II amarelos com manchas negras e áreas castanhas. Segmento III negro. Segmento IV negro, com exceção de um anel estreito e amarelo na base. Segmento V negro, com exceção do $1 / 3$ basal e ápice que são amarelos. Segmentos em ordem crescente de comprimento: I; II; III; IV e V subiguais.

Urotergito VII com um par de pequenas impressões e um par de grandes áreas membranosas laterais ao processo 
mediano (fig. 11). Processo mediano bem desenvolvido, parte livre curta, larga, convexa transversalmente, reta e dirigida póstero-ventralmente; ápice expandido e margem posterior inteira. Membrana apresentando um par de áreas parcialmente esclerotizadas e negras, localizadas junto à margem posterior do conexivo VII. Margem posterior do processo coincidindo com o final da membrana. Margem posterior do urosternito VII com um processo retangular (fig. 12).

Pigóforo. Projeções do bordo dorsal, laterais ao segmento $\mathrm{X}$, arredondadas e não projetadas em direção aos tubérculos deste (fig. 13, 15). Bordo ventral trapezoidal, alto, largo, côncavo, margem superior convexa, dobrada dorsalmente e mais larga que a extremidade do segmento X (fig. 14). Superfície ventral do pigóforo, logo abaixo do bordo ventral, apresentando uma pequena área escavada longitudinal e mediana, localizada entre duas grandes áreas intumescidas, recoberta por pêlos esparsos. Ângulo póstero-lateral do pigóforo quase 3 vezes mais longo que largo, em vista lateral. Ângulos retos, divergentes e com um tubérculo no 1/3 médio; face interna plana; face externa plana com pontos rasos interligados por faixas castanho-claras e apresentando muitos sulcos longitudinais; margem interna castanho-clara.

Cabeça do parâmero composta por 3 lobos visíveis (figs. 16-18). Dorsal inconspícuo; carena dorsal baixa e evanescente na altura da base dos lobos laterais. Lobo lateral interno longo, estreito, levemente curvado, dirigido látero-dorsalmente e com o ápice reto. Lobo lateral externo pequeno, triangular, reto e com o ápice truncado. Lobo ventral pequeno e cônico.

Segmento X (figs. 13,15) apresentando duas áreas túmidas ventrais que ocupam uma parte considerável da taça genital. Tubérculos desenvolvidos, auriculares, em vista posterior, e dirigidos dorso-posteriormente. Margens internas dos tubérculos projetadas obliquamente, em direção à linha media longitudinal, dando forma triangular ao ápice do segmento $\mathrm{X}$ e fundindo-se à carena mediana da face posterior. Face posterior convexa e perpendicular ao plano frontal do pigóforo; carenas laterais pouco desenvolvidas, quase inconspícuas; crista mediana elevada, percorrendo toda face.

Holótipo macho. "Brasil: Amazonas, 26 Km Norte Manaus, 14III-1970 col. D. Engleman", "Hemip 021” (INPA). Examinado.

Distribuição: Brasil, Amazonas: Manaus, Juruá (0334'85"S 66 59'15"W).

Comentários: Os dois exemplares conhecidos pertencem ao INPA. A. geometricus distingue-se das outras espécies pela presença de um par de pequenas impressões laterais ao processo mediano do urotergito VII; pela membrana do urotergito VII com um par de grandes áreas parcialmente esclerotizadas e negras junto às margens laterais; pela margem interna de cada ângulo póstero-lateral do pigóforo com um tubérculo no 1/3 mediano; pelo segmento X com duas grandes áreas túmidas que percorrem suas laterais. A. geometricus e $A$. exiguus compartilham o processo mediano do urotergito VII expandido no ápice; a presença de um processo retangular no urosternito VII; o bordo ventral alto e largo; o ângulo póstero-
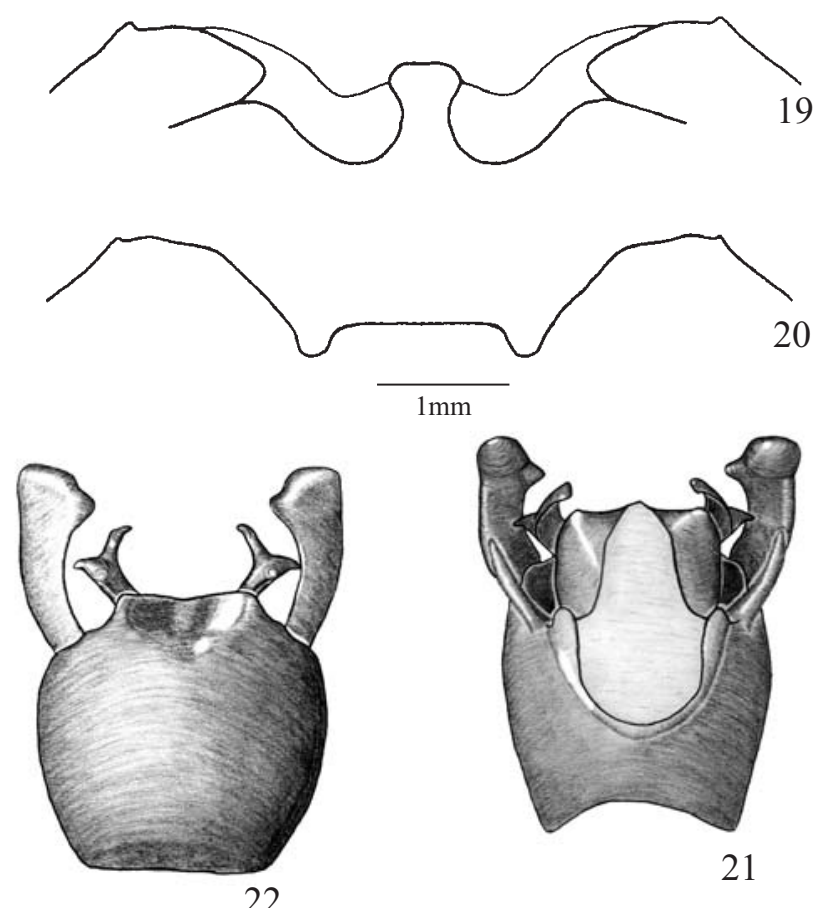

21

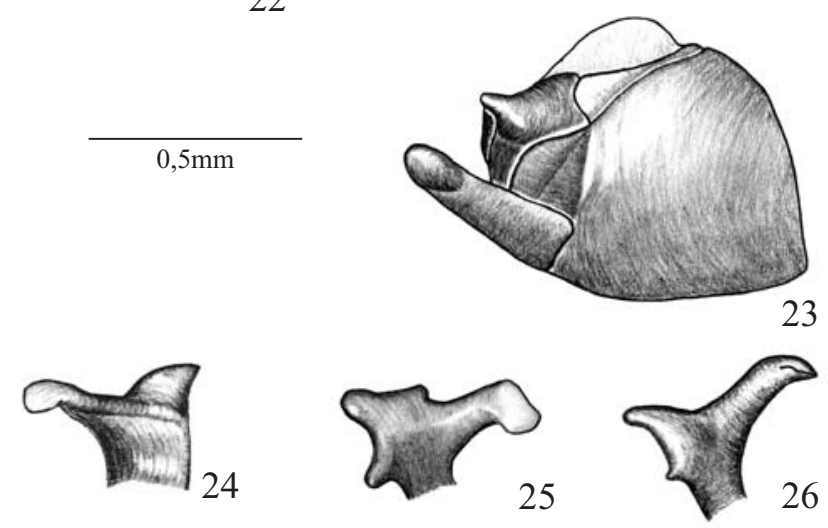

Figs. 19-26. Antiteuchus exiguus sp. nov. 19, Processo mediano do tergito VII; 20, Processo mediano do urosternito VII; 21-23, Pigóforo em vistas dorsal, ventral e lateral, respectivamente; 24-25, Parâmero em vistas dorsal, posterior e ventral, respectivamente.

lateral do pigóforo quase 3 vezes mais longo que largo; o lobo dorsal do parâmero inconspícuo; os tubérculos do segmento $\mathrm{X}$ auriculares, em vista posterior, e dirigidos dorsoposteriormente; e a face posterior do segmento X com carenas laterais quase inconspícuas.

\section{Antiteuchus exiguus sp. nov.} (Figs. 19-26, 302)

Etimologia. Latim-exiguus $=$ pequeno. Referência ao pequeno tamanho dos exemplares em comparação com as outras espécies do grupo.

Medidas $(n=9)$ : comprimento total- 10,3-11,8; largura total$6,7-7,2$. 
Segmento antenal I amarelo com manchas negras e áreas castanhas. Segmento II negro com a face lateral externa recoberta por manchas castanhas e castanho-escuras. Segmento III negro. Segmento IV negro, com exceção de um anel estreito e amarelo na base. Segmento V negro, com exceção do $1 / 3$ basal e ápice que são amarelos. Segmentos em ordem crescente de comprimento: I; II; III; IV e V subiguais.

Urotergito VII com um par de elevações divergentes laterais ao processo mediano. Processo mediano bem desenvolvido, parte livre curta, larga, fortemente convexa transversalmente, reta e dirigida póstero-ventralmente; ápice expandido e margem posterior inteira (fig. 19). Membrana não apresentando um par de áreas esclerotizadas junto à margem posterior de cada conexivo VII. Margem posterior do processo praticamente coincidindo com o final da membrana. Margem posterior do urosternito VII com um processo retangular (fig. 20).

Projeções do bordo dorsal, laterais ao segmento $\mathrm{X}$, arredondadas e não projetadas em direção aos tubérculos deste (figs. 21, 23). Bordo ventral trapezoidal, alto, largo, côncavo, margem superior reta, plana e mais larga que a extremidade do segmento X (fig. 22). Superfície ventral do pigóforo, logo abaixo do bordo ventral, apresentando uma pequena área escavada longitudinal, mediana e recoberta por pêlos esparsos. Ângulo póstero-lateral do pigóforo quase 3 vezes mais longo que largo, em vista lateral. Ângulos curvados internamente, sendo as metades anteriores divergentes, e apresentando um tubérculo junto ao ápice; face interna plana; face externa plana com pontos rasos interligados por faixas castanho-escuras e apresentando muitos sulcos longitudinais; margem interna castanho-escura.

Cabeça do parâmero composta por 3 lobos visíveis (figs. 24-26). Dorsal inconspícuo; carena dorsal baixa e evanescente na altura da base dos lobos laterais. Lobo lateral interno longo, estreito, levemente curvado, dirigido látero-dorsalmente e com o ápice achatado, levemente alargado e curvado ventrolateralmente. Lobo lateral externo pequeno, lingüiforme e reto. Lobo ventral pequeno e reduzido a uma convexidade da parede ou papiliforme.

Segmento X (figs. 21, 23) sem áreas túmidas ventrais. Tubérculos desenvolvidos, auriculares, em vista posterior, e dirigidos dorso-posteriormente. Margens internas dos tubérculos projetam-se obliquamente, em direção à linha média longitudinal, dando forma triangular ao ápice do segmento $\mathrm{X}$ e fundindo-se à carena mediana da face posterior. Face posterior convexa e perpendicular ao plano frontal do pigóforo; carenas laterais pouco desenvolvidas, quase inconspícuas; crista mediana elevada e percorrendo toda face.

Holótipo macho: Brasil, Amazonas: Coari, Rio Urucu, Loc-18,

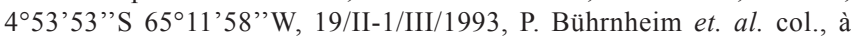
luz mista de mercúrio (INPA). Parátipos: Brasil, Amazonas: Juruá, Mineruazinho, 334'35'S 6659'15' W, 13-25/I/1996, P. Bührnheim, N. O. Aguiar et. al. col., à luz mista de mercúrio, 1 fêmea (INPA); Coari, Rio Urucu, Loc-18, 453'53”'S 6511'58'W, 19/II-1/III/1993, P. Bührnheim et. al. col., à luz mista de mercúrio, 1 fêmea (UFRG);

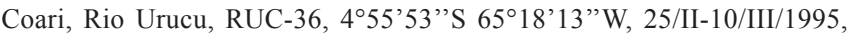
P. Bührnheim et. al. col., à luz mista de mercúrio, 1 fêmea e 1 macho

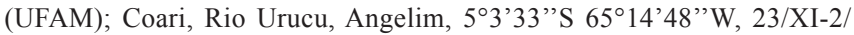

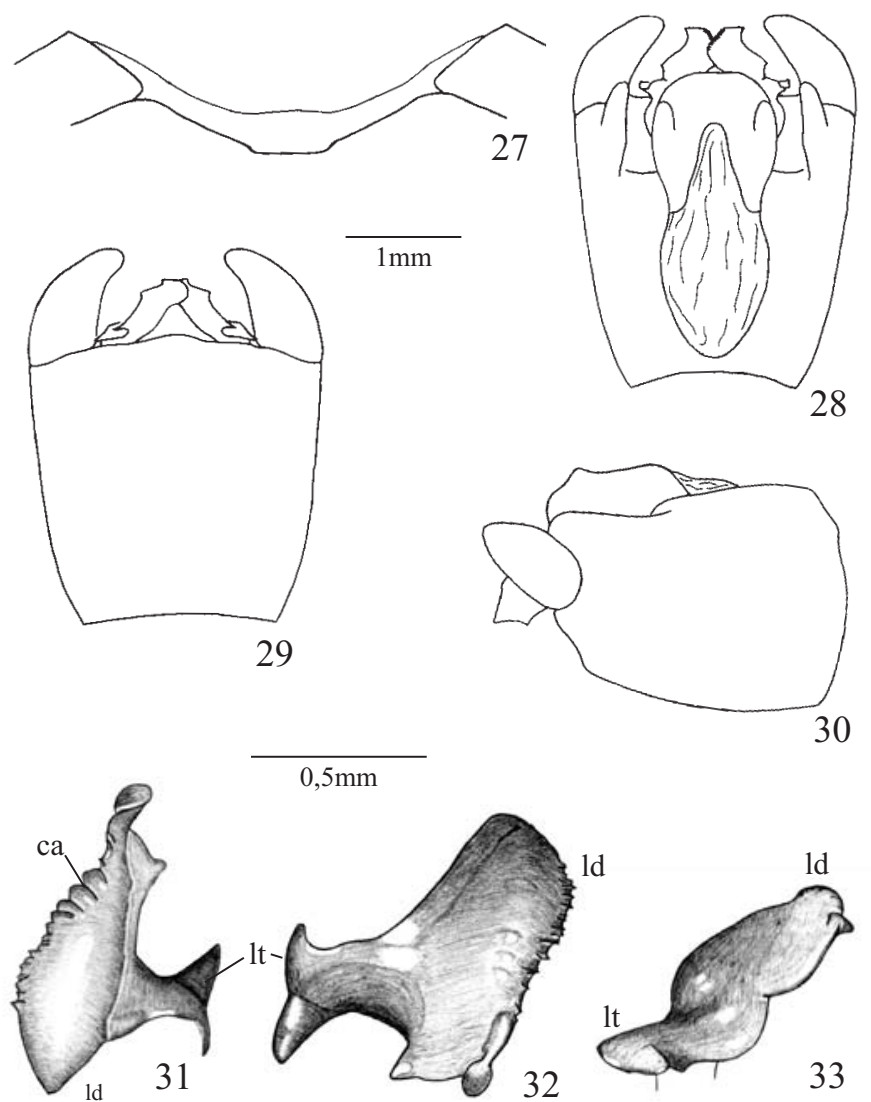

Figs. 27-33. Antiteuchus graziae. 27, Processo mediano do tergito VII; 28-30, Pigóforo em vistas dorsal, ventral e lateral, respectivamente; 31-33, Parâmero em vistas dorsal, posterior e ventral, respectivamente. (ca- carena; ld- lobo dorsal; lt- lobo lateral).

XII/1992, P. Bührnheim e N. O. Aguiar col., à luz mista de mercúrio, 1 macho e 1 fêmea (UFAM); Coari, Rio Urucu, Petrobrás RUC-29, 5-10/II/ 1992, P. Bührnheim, N. O. Aguiar e N. Fé col., 1 macho (UFRG) e 1 macho (MPEG).

Distribuição: Brasil, Amazonas: Juruá, Coari.

Comentários: Os exemplares analisados pertenciam à coleção do UFAM, o holótipo e os parátipos foram distribuídos com autorização da curadora. Esta espécie nova distingue-se das outras do grupo supinatus por ser a menor em tamanho; por apresentar um par de elevações laterais ao processo mediano do urotergito VII; pelos ângulos póstero-laterais do pigóforo curvados internamente; pelo parâmero com ápice do lobo lateral interno achatado, levemente alargado e curvado ventro-lateralmente.

Grupo A. amplus

(Figs. 27-61, 302)

Corpo achatado dorso-ventralmente, amarelo a amareloescuro e brilhante. Jugas com a margem externa castanhoescura. Hemiélitro com ápice agudo atingindo a metade posterior do conexivo VII, com exceção de $A$. graziae. Escutelo com ápice arredondado. Ventralmente o tórax apresenta 
pontuação castanha. Metapleura com um calo grande e amarelo junto à área evaporatória. Coxas e trocânteres amarelos e imaculados. Fêmures com muitas manchas escuras que aumentam de densidade em direção ao ápice. Tíbias geralmente avermelhadas e com pêlos de comprimento menor que o diâmetro do segmento. Tarsos geralmente avermelhados. Conexivo exposto. Coloração ventral do abdome amarela com manchas castanho-claras que diminuem de concentração da margem lateral para região mediana. Ângulos laterais de cada segmento com áreas castanho-escuras ou negras. Uma linha imaginária tangente à margem posterior do conexivo VII, não secciona o ângulo póstero-lateral do urotergito VII (figs. 27, 34). Processo mediano do urotergito VII sem uma lígula membranosa na extremidade posterior. Urotergito VII com um par de depressões que delimitam a base do processo mediano e sem processos espessados na margem; membrana desenvolvida e dobrada ventralmente, reduzida junto ao processo mediano, sem pêlos e estendendo-se por todo segmento, mesmo estando parcialmente encoberta pelo conexivo. Urosternito VII com a margem inteira, sem um processo retangular mediano.

Pigóforo com $1+1$ tufo de pêlos longos na lateral, junto aos ângulos póstero-laterais. Escavação do bordo dorsal três vezes mais profunda que larga (figs. 28, 35). Expansões do bordo dorsal, laterais ao segmento $\mathrm{X}$, não projetadas em direção aos tubérculos deste. Diafragma sem processos membranosos. Bordo ventral do pigóforo recoberto por uma fileira de pêlos longos concentrados junto ao ápice (fig. 57); biconvexo, com exceção de $A$. graziae, sendo cada elevação achatada e localizada próximo ao ângulo póstero-lateral do pigóforo; apresentando uma projeção membranosa dorsal e espessa, geralmente restrita à base das elevações. Superfície ventral do pigóforo, logo abaixo do bordo ventral, apresentando uma concavidade mediana com uma área central elevada (fig. 57). Ângulo póstero-lateral do pigóforo pelo menos três vezes mais longo que largo em vista lateral; convergentes, não obstruindo a visão da taça genital em vista posterior; mais longo que a área esclerotizada do segmento X; e implantados no plano longitudinal do pigóforo (figs. 37, 58). Face dorsal deste Ângulo sem uma prega transversal.

Cabeça e corpo do parâmero subparalelos ao eixo longitudinal do pigóforo (figs. 35, 56). Cabeça bem desenvolvida e composta por dois lobos: um dorsal (ld), grande, delgado e com várias carenas (ca) transversais na margem; e outro lateral (lt), pequeno e dividido em dois pequenos processos (figs. 31-33, 59-61).

Segmento $\mathrm{X}$ sem áreas látero-dorsais intumescidas, recoberto por pêlos esparsos na face posterior, tubérculos e margem ventral. Face posterior estriada transversalmente, sem crista mediana e com uma área mediana intumescida junto à margem ventral. Ductus seminis distalis muito mais longo que o falo.

Comentários: Este grupo é formado por A. amplus, $A$. graziae, A. nebulosus, A. ruckesi e A. rufitarsus. O grupo pode ser caracterizado pela presença de um par de depressões laterais à base do processo mediano do urotergito VII; pela

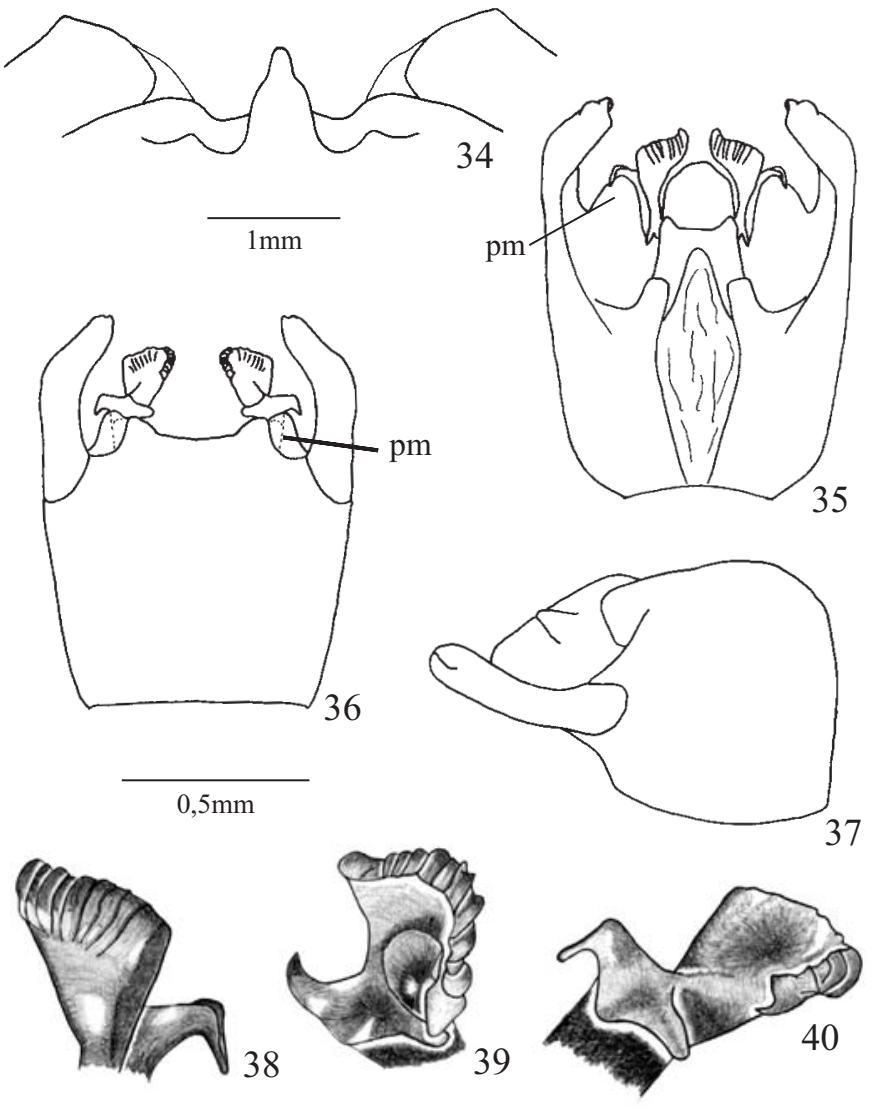

Figs. 34-40. Antiteuchus amplus. 34, Processo mediano do tergito VII; 35-37, Pigóforo em vistas dorsal, ventral e lateral, respectivamente; 38-40, Parâmero em vistas dorsal, posterior e ventral, respectivamente. pm- projeções membranosas do bordo ventral.

membrana do urotergito VII larga, dobrada ventralmente e reduzida junto ao processo mediano; pela escavação do bordo dorsal do pigóforo pelo menos três vezes mais profunda que larga; pelo bordo ventral do pigóforo com duas fileiras de pêlos longos sobre expansões (exceto A. graziae), e com uma projeção membranosa dorsal espessa; pelo ângulo pósterolateral do pigóforo pelo menos três vezes mais longo que largo em vista lateral; pela face dorsal deste ângulo sem uma prega transversal; pela cabeça e corpo do parâmero subparalelos ao eixo longitudinal do pigóforo; pela forma do parâmero, principalmente a presença de carenas bem desenvolvidas sobre a margem do lobo dorsal; pela presença de uma área intumescida sobre a face posterior do segmento X; pelo ductus seminis distalis muito mais longo que o falo, pelo menos quatro vezes mais.

\section{Chave de identificação para os machos das espécies do grupo A. amplus}

1. Processo mediano do urotergito VII ausente, no lugar ocorre uma concavidade rasa. Processo látero-dorsal do pigóforo muito desenvolvido, projetando-se sobre a base do ângulo póstero-lateral do pigóforo. Lobo 
dorsal do parâmero com muitas carenas baixas na margem (figs. 27, 30, 32) ........................... A. graziae

Processo mediano do urotergito VII presente. Processo látero-dorsal do pigóforo inconspícuo, no local a parede do pigóforo é intumescida, recoberta por pêlos e com textura própria. Lobo dorsal do parâmero com carenas altas na margem (figs. $34,37,39,55,58,60$ ) ...

2(1). Processo mediano do urotergito VII desenvolvido e afilado no ápice. Lobo dorsal do parâmero com mais de 10 carenas na margem (figs. 34, 39) ......... A. amplus

Processo mediano do urotergito VII reduzido a uma pequena convexidade da margem. Lobo dorsal do parâmero com menos de oito carenas na margem (figs. $48,53,55,60)$ ... 3

3(2). Bordo dorsal com um par de áreas intumescidas laterais ao segmento X. Lobo dorsal do parâmero sem expansão após as carenas (figs. $49,53,56,60)$......... 4

Bordo dorsal do pigóforo sem um par de áreas intumescidas laterais ao segmento X. Lobo dorsal do parâmero com uma expansão apical longa, após as carenas (figs. 42, 46) A. nebulosus

4(3). Ângulo póstero-lateral do pigóforo com uma área achatada e escura próxima ao ápice. Tubérculos do segmento X retos e paralelos (fig. 56, 58) .. A. rufitarsus

Ângulo póstero-lateral do pigóforo sem uma área achatada próxima ao ápice. Tubérculos do segmento X curvados e convergentes (fig. 49, 51) ......... A. ruckesi

Antiteuchus graziae Engleman, 1983

(Figs. 27-33, 302)

Antiteuchus (Antiteuchus) graziae Engleman, 1983 (in Engleman \& Rolston, 1983): 185-187, figs. 12, 15, 20; Rolston, 1991: 235 (chave); Rolston, 1993: 109 (chave), 110, figs. 1-2.

Medidas ( $\mathrm{n}=10)$ : comprimento total- 12,3-13,6; largura total$8,0-8,2$.

Pontuação dorsal densa, distribuída homogeneamente, alguns pontos são recobertos por linhas sinuosas castanhoescuras ou claras. Segmento antenal I amarelo com muitas manchas escuras. Segmentos II e III castanho-escuros a negros com manchas amarelas. Segmento IV com 1/4 basal amarelo-escuro e o restante negro. Segmento V amarelo-claro. Segmentos antenais em ordem crescente de comprimento: II; I; III; IV; V.

Disco do pronoto com coloração uniforme. Hemiélitro ultrapassando o final do abdome nos machos, pontuação distribuída regularmente, apresentando uma mancha castanha na metade posterior. Escutelo sem manchas, mas com a pontuação do $1 / 3$ basal maior que a do restante do escutelo. Ápice do escutelo ultrapassando o final do segmento VII. Ventralmente tórax com pontuação castanho-escura ou negra. Mesopleura com um pequeno calo amarelo. Fêmures amarelos com muitas manchas negras. Tíbias amarelas ou levemente
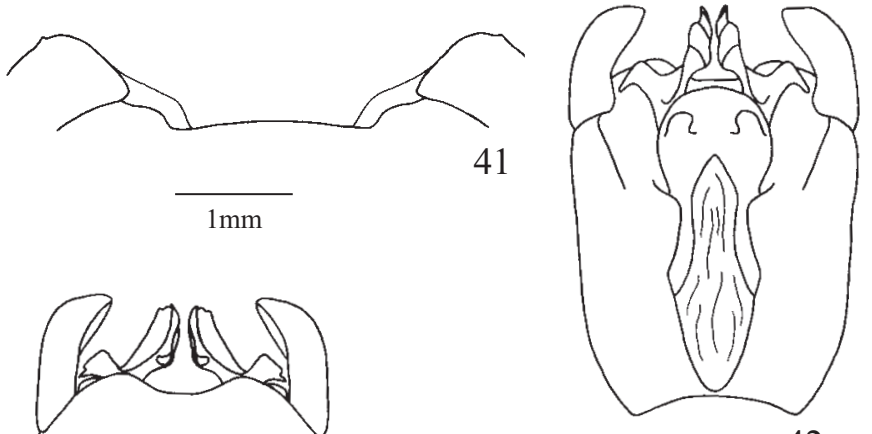

42

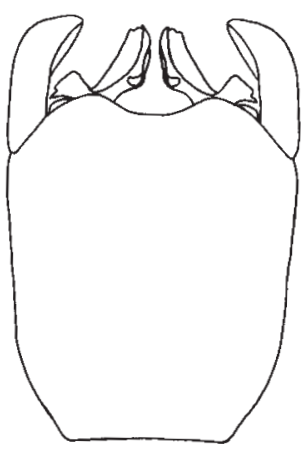

43
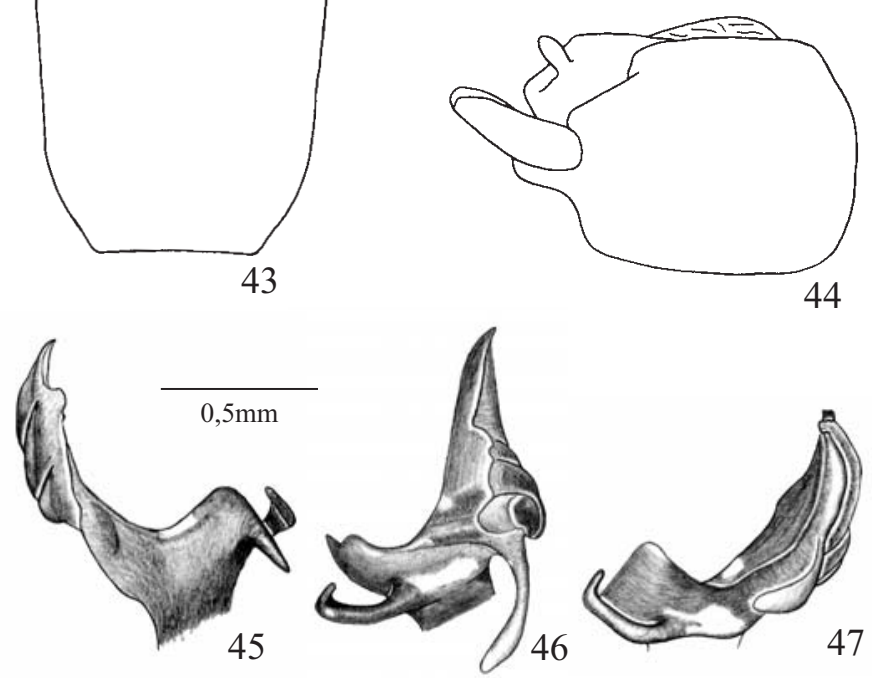

Figs. 41-47. Antiteuchus nebulosus. 41, Processo mediano do tergito VII; 42-44, Pigóforo em vistas dorsal, ventral e lateral, respectivamente; 45-47, Parâmero em vistas dorsal, posterior e ventral, respectivamente.

avermelhadas com muitas manchas negras. Tarsos claros. Conexivo amarelo com os ângulos laterais externos negros. Coloração dorsal do abdome castanho-clara e ventral amarela. Região calosa interna aos espiráculos mais clara que o restante do abdome. Urotergito VII com um par de pequenos sulcos quase imperceptíveis laterais à concavidade mediana. Processo mediano ausente, no local existe uma concavidade rasa (fig. 27).

Pigóforo amarelo-escuro. Bordo dorsal com projeções laterais ao segmento $\mathrm{X}$ arredondadas e sem áreas intumescidas. Processo látero-dorsal muito desenvolvido, arredondado, projetado sobre o $1 / 3$ basal do ângulo póstero-lateral do pigóforo, sem fusionar-se a ele (figs. 28, 30). Bordo ventral levemente convexo; as elevações do bordo estão reduzidas a carenas baixas, espessadas, escuras e recobertas por uma fileira de pêlos concentrados junto as laterais (fig. 29). Bordo ventral com projeção membranosa reduzida a uma prega na margem do próprio bordo. Ângulo póstero-lateral do pigóforo ogival em vista lateral, quase três vezes mais longo que largo, em vista lateral, e curvado para o lado interno. Face lateral interna deste ângulo plana; face dorsal com uma área plana no 1/3 basal e uma concavidade rasa na metade superior; face ventral e lateral externa convexa e com muitas manchas castanho-claras. 
Cabeça do parâmero (figs. 31-33) apresentando o lobo dorsal extremamente desenvolvido e ovalado, parte superior curvada lateralmente sobre o segmento $\mathrm{X}$, margem dorsal apresentando mais de dez carenas pequenas e transversais; margem posterior com duas pequenas projeções, uma ventral triangular e outra dorsal arredondada e achatada. Lobo lateral achatado ântero-posteriormente composto por dois processos achatados, triangulares e opostos, sendo um dirigido dorsoanteriormente e o outro ventralmente.

Segmento X arredondado, tubérculos desenvolvidos, paralelos, achatados lateralmente, dirigidos dorsoposteriormente e implantados longitudinalmente sobre o segmento X (fig. 28). Face posterior com carenas laterais pouco desenvolvidas, pouco inclinada em relação ao plano transversal do pigóforo e sem uma área intumescida mediana. Área membranosa dorsal terminando na base dos tubérculos.

Holótipo fêmea. "Brazil, Mato Gr.; 10²5'S 59²8'W; 17-22.III.77, 300m, Col: D. Engleman” (INPA). Examinado. O parátipo macho também foi examinado.

Distribuição: Colômbia, Vaupés: Raudal do Chiribiquete (104'19”N 72 40’05”W). Brasil, Amazonas: Manaus; Pará: Medicilândia; Rondônia: Ouro Preto d'Oeste; Mato Grosso: Aripuanã ( $\left.10^{\circ} 25^{\prime} \mathrm{S} 59^{\circ} 28^{\prime} \mathrm{W}\right)$. Equador, Napo: Coca. Perú, Junin: Junin. Bolívia, La Paz: Caranavi.

Comentários: Os exemplares analisados pertencem às coleções do AMNH, BMNH, MCNZ, MLPA e UFRG. A. graziae pode ser facilmente distinguida pelo ápice do escutelo ultrapassando o final do segmento VII; pelo urotergito VII com uma concavidade mediana em vez de um processo; pelo bordo ventral levemente convexo; pelo processo látero-dorsal muito desenvolvido, arredondado, projetado sobre a base do ângulo póstero-lateral do pigóforo; pela forma do parâmero; pelo segmento $\mathrm{X}$ sem área intumescida mediana na face posterior. Esta espécie compartilha com A. amplus a oposição entre os processos que formam o lobo lateral do parâmero. $A$. graziae tem como característica comum com A. nebulosus a presença de carenas laterais pouco desenvolvidas sobre a face posterior do segmento X. A. graziae assemelha-se com A. nebulosus e A. ruckesi na forma do ápice de cada ângulo póstero-lateral do pigóforo. Esta espécie tem como características comuns com $A$. nebulosus, A. ruckesi e $A$. rufitarsus a projeção membranosa do bordo ventral do pigóforo reduzida a uma prega na margem do próprio bordo, e o lobo lateral do parâmero achatado ântero-posteriormente.

\section{Antiteuchus amplus (Walker, 1867)}

(Figs. 34-40, 302)

Discocephala ampla Walker, 1867: vol. 1, 187-188; Lethierry \& Severin, 1893: 83 (catálogo).

Dinocoris amplus; Distant, 1899: 444

Mecistorhinus amplus; Kirkaldy, 1909:218 (catálogo); Costa Lima, 1940: 54

Antiteuchus (Antiteuchus) amplus; Ruckes, 1964: 84 (chave), 86-87, figs. 42-44; Rolston, 1993: 109 (chave), 115-116, figs. 25-27.

Antiteuchus (Antiteuchus) englemani Rolston, 1993: 109 (chave), 118121, figs. 41-44. SIN. NOV.
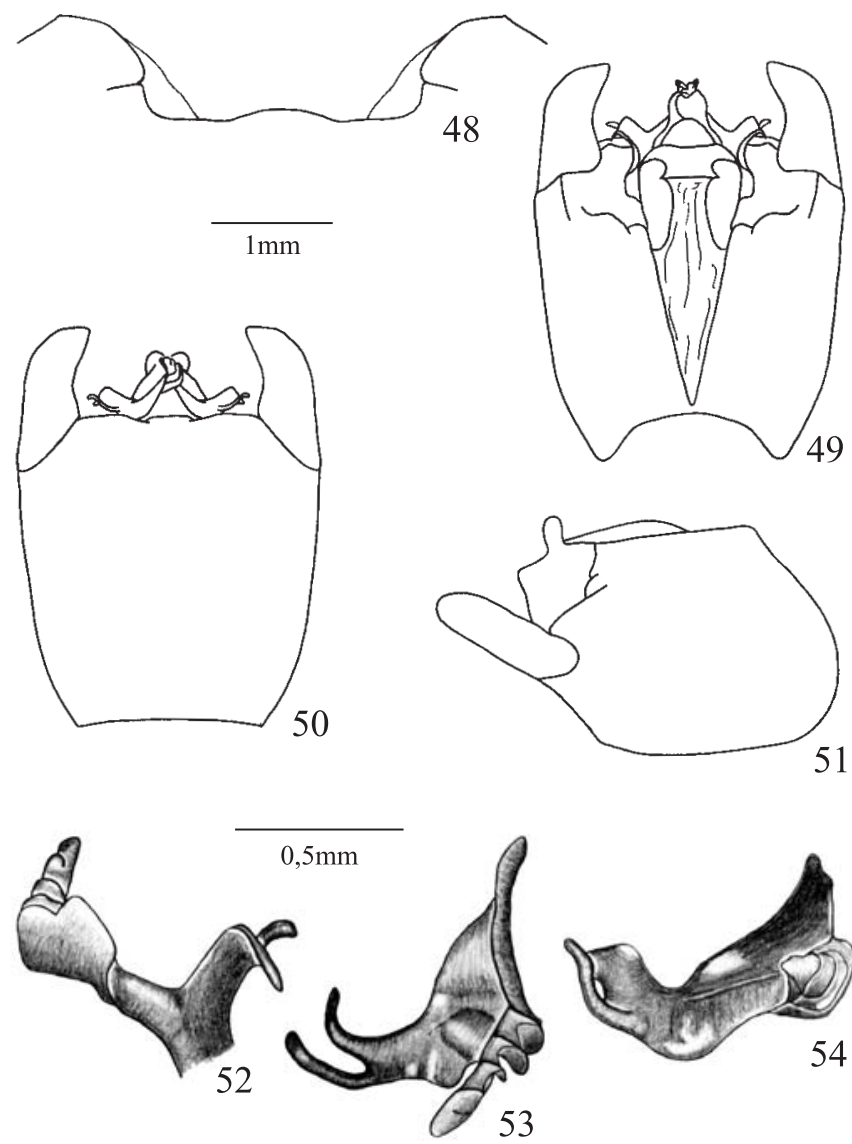

Figs. 48-54. Antiteuchus ruckesi. 48, Processo mediano do tergito VII; 49-51, Pigóforo em vistas dorsal, ventral e lateral, respectivamente; 52-54, Parâmero em vistas dorsal, posterior e ventral, respectivamente.

Medidas ( $\mathrm{n}=5)$ : comprimento total- $12,0-15,2$; largura total7,7-9,0.

Superfície dorsal com pontuação densa e envolvida por linhas sinuosas e manchas, coloração variegada. Metade posterior do pronoto mais escura que a anterior. Segmentos antenais I e II amarelo-escuros com muitas manchas negras. Segmento III negro com manchas amarelo-escuras. Segmento IV negro com $1 / 3$ basal amarelo. Segmento V negro com metade basal e ápice amarelo-escuro. Segmentos antenais em ordem crescente de comprimento: I; II; III; IV e V subiguais.

Ápice do escutelo atingindo a metade do segmento VII. Ventralmente o tórax é mais claro e apresenta pontuação da margem posterior do metasterno mais escura. Mesopleura com um pequeno calo amarelo. Fêmures amarelo-escuros com manchas negras. Tíbias avermelhadas com manchas negras. Tarsos avermelhados. Conexivo com regiões intersegmentares escuras separadas por áreas amarelas. Coloração dorsal do abdome castanho-clara e ventral amarela. Região calosa interna aos espiráculos inconspícua. Urotergito VII (fig. 34) com 1+1 projeções mais escuras, triangulares e um pouco elevadas, laterais as depressões largas e profundas que delimitam a base do processo mediano. Processo mediano, bem desenvolvido, estreitado apicalmente, margem posterior inteira. Ápice do processo ultrapassando muito a margem da membrana. 
Pigóforo amarelo. Bordo dorsal sem áreas intumescidas e com projeções laterais ao segmento X dentiformes (fig. 37). Processo látero-dorsal inconspícuo devido ao intumescimento de toda região lateral, mas a textura, presença de pêlos e uma pequena elevação na base de cada ângulo póstero-lateral do pigóforo assinalam tal região (fig. 35). Elevações do bordo ventral triangulares e recobertas por uma fileira de pêlos concentrados na margem lateral externa. Região mediana do bordo ventral com uma projeção retangular; projeções membranosas (pm) ultrapassando os limites das elevações triangulares (figs. 35-36). Ângulo póstero-lateral do pigóforo sub-retangular em vista lateral, quatro vezes mais longo que largo e inclinado para o lado interno na metade apical. Ápice truncado com uma aba transversal achatada na margem, castanho-escuro e com uma carena negra longitudinal mediana bem desenvolvida. Face lateral interna levemente côncava; face dorsal plana na metade basal; face ventral e lateral externa convexas e com muitas manchas castanho-claras, sendo a última estreitada em direção ao ápice.

Cabeça do parâmero (figs. 38-40) apresentando o lobo dorsal extremamente desenvolvido, arredondado, côncavo em vista ventral e com aproximadamente dez carenas bem desenvolvidas e transversais localizadas sobre a margem do lobo dorsal, projeção ventral estreitando-se progressivamente em direção ao ápice. Lobo lateral achatado dorso-ventralmente e composto por dois processos pequenos e opostos, sendo o menor plano e ventral, e o maior curvado dorso-anteriormente.

Segmento X semicilíndrico, estriado transversalmente, tubérculos desenvolvidos, dirigidos posteriormente, achatados e implantados transversalmente sobre o segmento $\mathrm{X}$ (fig. 35, 37). Face posterior sem carenas laterais, pouco inclinada em relação ao plano transversal do pigóforo e com a área intumescida mediana bem desenvolvida. Área membranosa dorsal terminando antes da base dos tubérculos.

D. ampla: Holótipo fêmea. "26. Discocephala ampla", "Villa Nova", "type", "Brit. Mus. Type n Hem 673" (BMNH). Examinado. Ruckes (1964) acrescenta mais dados de localização, Villa Nova, Amazonas, Brasil.

A. englemani: Holótipo macho. "ECUADOR; Napo, Coca. 250m iii-iv-1982. G. Onore", “Amazonian Rain Forest”, "Brit. Mus. 1982246" (BMNH). Examinado.

Distribuição: Guiana Francesa, Cayenne. Brasil, Amazonas: Vila Nova; Bahia: Ilhéus; Rio de Janeiro: Rio de Janeiro. Equador, Napo: Coca. PERÚ, Loreto: Rio Ucayali. BOLÍVIA, Cochabamba: Rio Cristal ( $50 \mathrm{Km}$ NE de Cochabamba).

Comentários: Os exemplares examinados pertencem às coleções do AMNH, BMNH e MNRJ. Os indivíduos mencionados por Ruckes (1964) como sendo provenientes de Ilhéus e Rio de Janeiro provavelmente foram identificados erroneamente ou houve um erro na indicação do local de origem do material, pois a espécie possui uma distribuição amazônica. Esta espécie pode ser reconhecida pelo urotergito VII com um par de áreas mais escuras, triangulares e um pouco elevadas, laterais ao processo mediano; pelo processo mediano bem desenvolvido e estreitado no ápice; pelas elevações do bordo ventral do pigóforo triangulares; pelas projeções membranosas

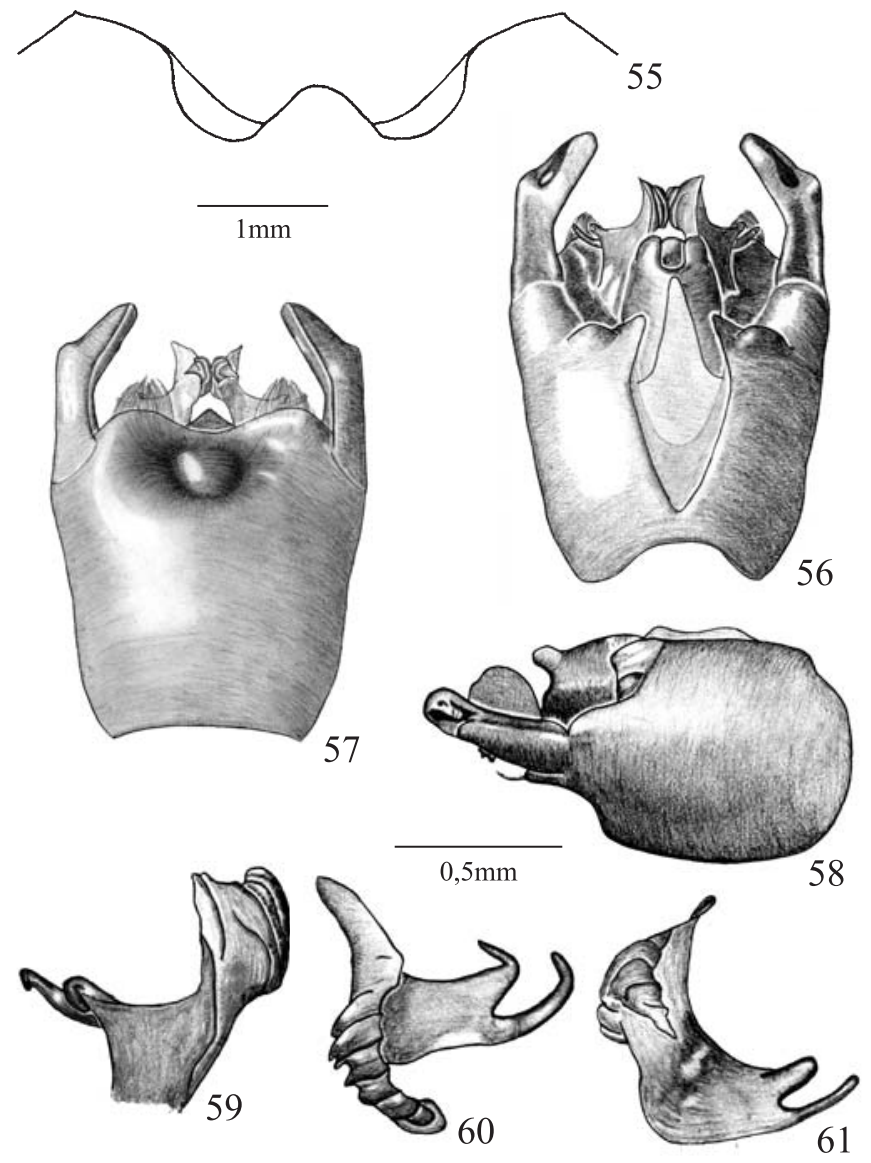

Figs. 55-61. Antiteuchus rufitarsus. 55, Processo mediano do tergito VII; 56-58, Pigóforo em vistas dorsal, ventral e lateral, respectivamente; 59-61, Parâmero em vistas dorsal, posterior e ventral, respectivamente.

do bordo ventral do pigóforo ultrapassando os limites das elevações triangulares; pelo ápice de cada ângulo pósterolateral do pigóforo com uma carena negra longitudinal e mediana; pela forma do parâmero; pela face posterior do segmento X sem carenas laterais e com uma área intumescida mediana bem desenvolvida. A. amplus e A. nebulosus têm como característica comum mais importante a presença de depressões largas e profundas que delimitam a base do processo mediano do urotergito VII. A. amplus compartilha com $A$. nebulosus, $A$. ruckesi e $A$. rufitarsus o processo láterodorsal quase inconspícuo, reconhecido devido à textura, presença de pêlos e uma pequena elevação na base de cada ângulo póstero-lateral do pigóforo. Esta espécie possui em comum com $A$. rufitarsus o ângulo póstero-lateral do pigóforo quatro vezes mais longo que largo, em vista lateral, e bruscamente inclinado para o lado interno na metade distal; ápice truncado com uma aba transversal achatada na margem.

Antiteuchus nebulosus Ruckes, 1964

(Figs. 41-47, 302)

Antiteuchus (Antiteuchus) nebulosus Ruckes, 1964: 84 (chave), 8991, figs. 10, 53-55; Rolston, 1991: 235 (chave); Rolston, 1993: 109 (chave), 111-112, figs. 6-8. 

8,7 .

Medidas do holótipo: comprimento total-15,6; largura total-

Superfície dorsal com pontuação densa envolvida por linhas sinuosas e manchas, coloração variegada. Metade posterior do pronoto mais escura que a anterior. Segmentos antenais I e II amarelos com muitas manchas escuras. Segmento III com metade distal negra e metade basal clara. Segmento IV negro com 1/3 basal amarelo. Segmento V perdido, mas Ruckes (1964) afirmou que este segmento possuia coloração igual a do segmento IV. Segmentos antenais em ordem crescente de comprimento: I e II subiguais; III; IV. Segundo Ruckes (1964) os artículos IV e V eram subiguais em comprimento.

Ápice do escutelo quase atingindo o final do segmento VII. Ventralmente tórax com pontuação negra na margem posterior do metasterno. Mesopleura com um amplo calo amarelo. Fêmures amarelos com manchas castanho-escuras. Tíbias avermelhadas com manchas escuras. Tarsos avermelhados. Conexivo com regiões intersegmentares escuras separadas por áreas amarelas. Coloração dorsal do abdome castanho-claro e ventral amarelo-escura. Região calosa interna aos espiráculos inconspícua. Urotergito VII com depressões largas e profundas que delimitam a base do processo mediano. Processo mediano do urotergito VII pouco desenvolvido, formado apenas por uma leve convexidade da margem posterior (fig. 41).

Pigóforo amarelo. Bordo dorsal com projeções laterais ao segmento $\mathrm{X}$ arredondadas e sem áreas intumescidas (figs. 42, 44). Processo látero-dorsal inconspícuo devido ao intumescimento de toda região lateral, mas a textura, presença de pêlos e uma pequena elevação na base de cada ângulo póstero-lateral do pigóforo assinalam tal região (fig. 44). Elevações do bordo ventral arredondadas e recobertas por uma fileira de pêlos concentrados na margem lateral junto ao ápice, diminuindo de densidade ao longo da margem interna; região mediana côncava, sem uma projeção retangular (fig. 43). Bordo ventral com projeção membranosa limitada à base das elevações arredondadas. Ângulo póstero-lateral do pigóforo sub-retangular em vista lateral, três vezes mais longo que largo e curvado para o lado interno. Ápice truncado com uma aba transversal pouco achatada na margem. Face lateral interna levemente côncava; face dorsal sulcada na metade basal e próximo ao ápice; face ventral e lateral externa convexa.

Cabeça do parâmero (figs. 45-47) apresentando o lobo dorsal extremamente desenvolvido, arredondado e com quatro carenas transversais bem desenvolvidas, apresenta também uma projeção ventral que se estreita progressivamente e é levemente torcida no ápice. Lobo lateral achatado ânteroposteriormente e composto por dois processos pequenos e sobrepostos, sendo o inferior digitiforme, com ápice achatado e dirigido dorso-posteriormente; processo superior mais longo que o inferior, achatado, afilado em direção ao ápice e curvado ântero-lateralmente.

Segmento X semicilíndrico, estriado transversalmente, tubérculos muito desenvolvidos, digitiformes, curvados, convergentes, dirigidos dorso-posteriormente e implantados transversalmente sobre o segmento X (figs. 42, 44). Face

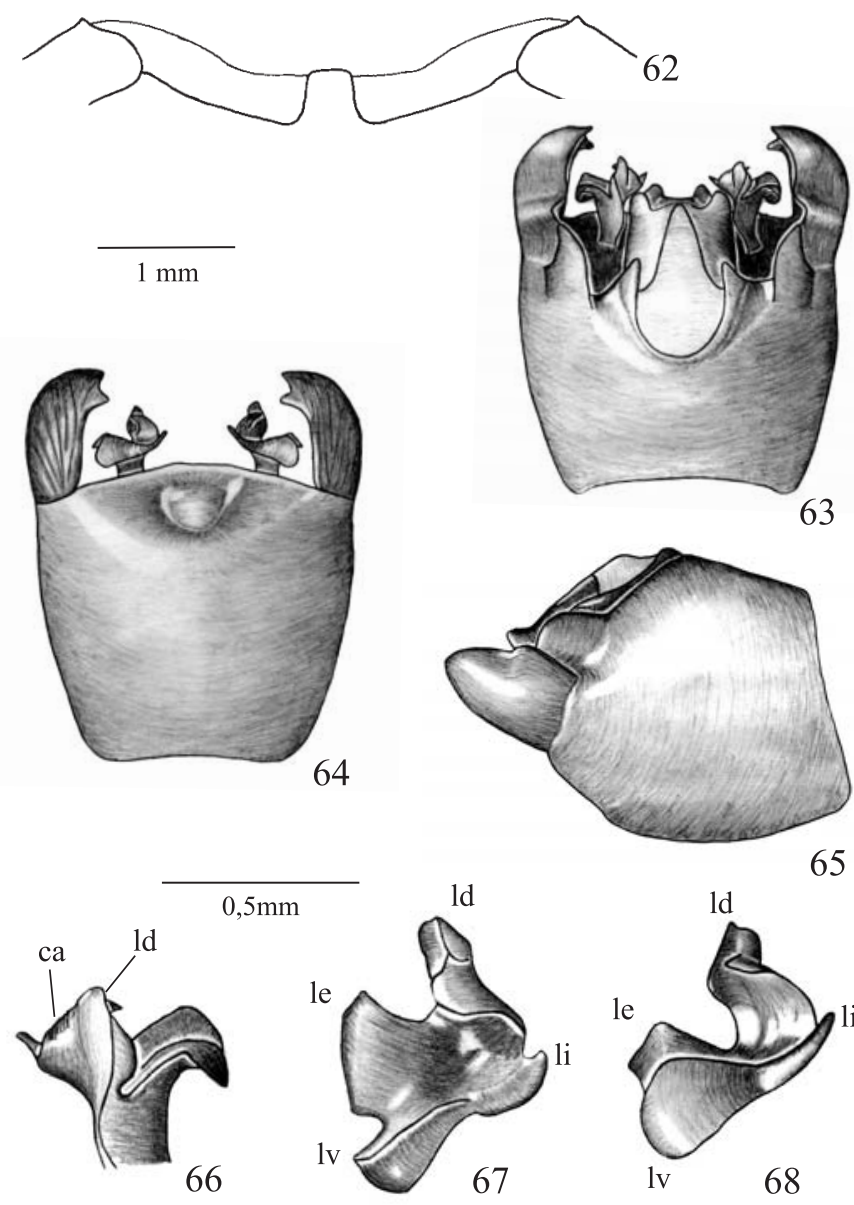

Figs. 62-68. Antiteuchus pallescens. 62, Processo mediano do tergito VII; 63-65, Pigóforo em vistas dorsal, ventral e lateral, respectivamente; 66-68, Parâmero em vistas dorsal, posterior e ventral, respectivamente. (ca- carenas; ld- lobo dorsal; le- lobo lateral externo; li- lobo lateral interno; lv- lobo ventral).

posterior com carenas laterais pouco desenvolvidas, pouco inclinada em relação ao plano frontal do pigóforo e com a área intumescida mediana bem desenvolvida. Área membranosa dorsal terminando antes da base dos tubérculos.

Holótipo macho. "Nova Teutonia, Santa Catarina, Brazil; July 1948; A. Maller coll.” (AMNH). Examinado.

Distribuição: Brasil, Rio de Janeiro: Rio de Janeiro; Paraná: Ouro Preto; Santa Catarina: Nova Teutônia.

Comentários: Somente o holótipo foi examinado. Esta espécie pode ser distinguida das demais apenas pela forma do parâmero, sendo o lobo dorsal arredondado, com quatro carenas transversais bem desenvolvidas na margem e projeção ventral estreita e levemente torcida no ápice; extremidade do processo inferior do lobo lateral do parâmero com o ápice achatado e processo superior mais longo que o inferior. Esta espécie tem em comum com $A$. ruckesi e $A$. rufitarsus o lobo lateral do parâmero formado por dois processos sobrepostos, e o processo mediano do urotergito VII pouco desenvolvido, 
formado apenas por uma convexidade da margem. A. nebulosus é semelhante a $A$. ruckesi pois os tubérculos do segmento $\mathrm{X}$ são muito desenvolvidos, digitiformes e curvados um para o outro.

Antiteuchus ruckesi Rolston, 1991

(Figs. 48-54, 302)

Antiteuchus (Antiteuchus) ruckesi Rolston, 1991: 235 (chave), 235239, figs. 1-6; Rolston, 1993: 109 (chave), 110-111, figs. 3-5.

Medidas ( $\mathrm{n}=3)$ : comprimento total- 12,8-14,8; largura total$8,0-8,7$.

Superfície dorsal com pontuação densa recoberta por linhas sinuosas e manchas, coloração variegada. Segmentos antenais I e II amarelos com manchas. Metade distal dos segmentos III e IV negros com um anel amarelo na base. Segmento V amarelo com um anel negro na metade distal. Segmentos antenais em ordem crescente de comprimento: I; II; III; IV e V subiguais.

Ápice do escutelo quase atingindo o final do segmento VII. Ventralmente o tórax apresenta pontuação negra na margem posterior do metasterno. Mesopleura com um amplo calo amarelo. Fêmures amarelos com manchas escuras. Tíbias avermelhadas com manchas negras. Tarsos avermelhados. Conexivo alternando áreas escuras nas regiões intersegmentares com áreas amarelo-claras. Coloração dorsal do abdome castanho-escuro e ventral amarelo-clara. Região calosa interna aos espiráculos inconspícua. Urotergito VII com as depressões que delimitam a base do processo mediano estreitas e rasas. Processo mediano do urotergito VII pouco desenvolvido, formado apenas por uma convexidade da margem posterior (fig. 48).

Pigóforo amarelo. Bordo dorsal com um par de áreas intumescidas laterais ao segmento $\mathrm{X}$ e projeções dentiformes. Processo látero-dorsal inconspícuo devido ao intumescimento de toda região lateral, mas a textura, presença de pêlos e uma pequena elevação na base de cada ângulo póstero-lateral do pigóforo assinalam tal região (figs. 49, 51). Elevações do bordo ventral truncadas, recobertas por uma fileira de pêlos concentrados no ápice, diminuindo de densidade ao longo da margem interna; região mediana plana (fig. 50). Bordo ventral com projeção membranosa limitada à base das elevações truncadas. Ângulo póstero-lateral do pigóforo sub-retangular, em vista lateral, três vezes mais longo que largo e curvado para o lado interno. Ápice truncado com uma aba transversal pouco achatada na margem. Face lateral interna plana; face dorsal levemente sulcada na metade basal e apresentando uma concavidade na metade superior; face ventral e lateral externa convexa.

Cabeça do parâmero (figs. 52-54) com o lobo dorsal extremamente desenvolvido, triangular e recoberto por quatro carenas transversais bem desenvolvidas, apresenta também uma projeção ventral que se estreita progressivamente em direção ao ápice. Lobo lateral achatado ântero-posteriormente e composto por dois processos sobrepostos, sendo o inferior digitiforme, tão longo quanto o anterior, curvado e com ápice
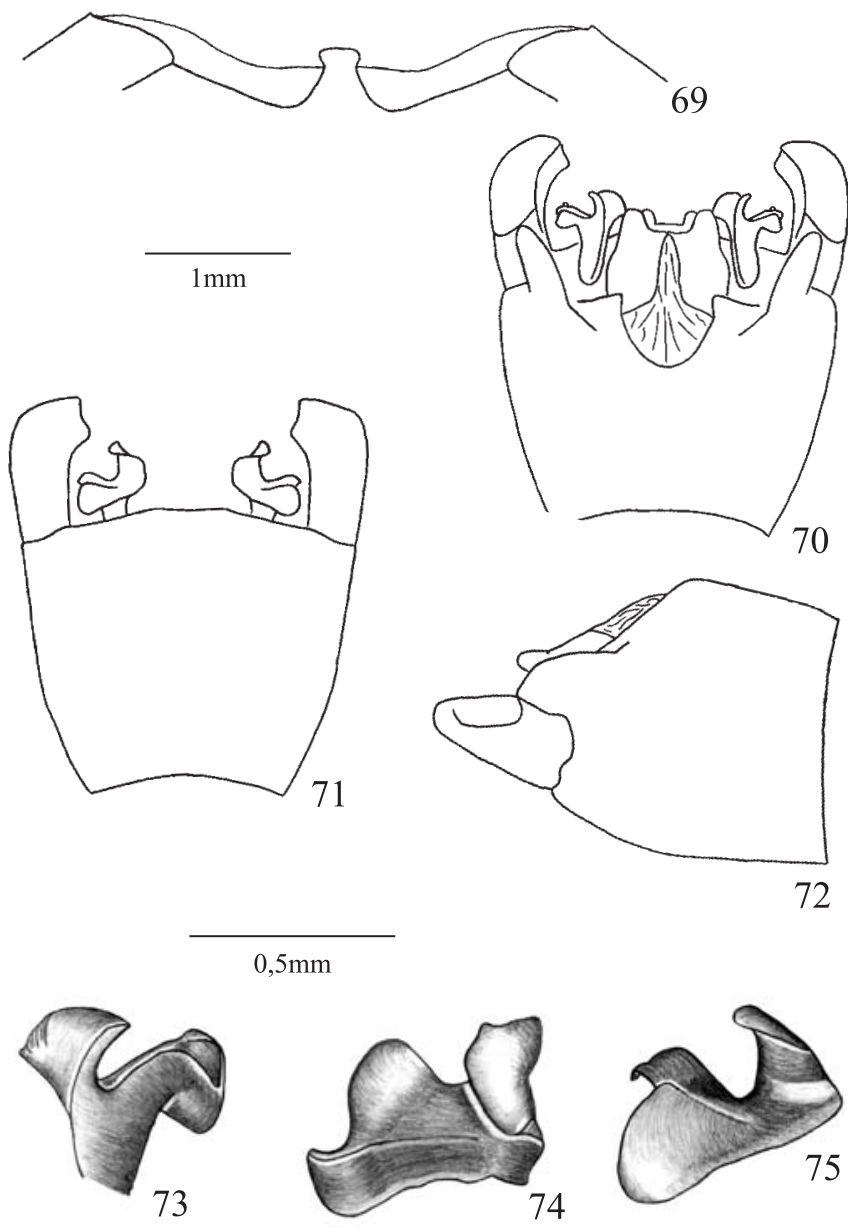

Figs. 69-75. Antiteuchus rideri. 69, Processo mediano do tergito VII; 70-72, Pigóforo em vistas dorsal, ventral e lateral, respectivamente; 73-75, Parâmero em vistas dorsal, posterior e ventral, respectivamente.

dirigido anteriormente, e o superior achatado e fortemente curvado anteriormente.

Segmento $\mathrm{X}$ semicilíndrico, tubérculos muito desenvolvidos, convergentes, digitiformes, com ápice curvado em direção ao do outro e implantados transversalmente sobre o segmento X (figs. 49, 51). Face posterior perpendicular em relação ao plano frontal do pigóforo, com carenas laterais bem desenvolvidas e com a área intumescida mediana desenvolvida. Área membranosa dorsal terminando na base dos tubérculos.

Holótipo macho. "PERU: Madre de Dios, Manu National Park; at UV light trap, 15 Aug. 1980-30 Nov. 1981, Charles H. Janson cllr., gift from Burke Museum mounted from alcohol 1986", "California Academy of Sciences Type no 16649" (CASC). Examinado.

Distribuição: Perú, Madre de Dios: Parque Nacional Manú.

Comentários: Os exemplares analisados pertencem à coleção do CASC. Esta espécie distingue-se das demais pela forma truncada das elevações do bordo ventral do pigóforo; pelo lobo lateral do parâmero com processo inferior tão longo 
quanto o superior. A. ruckesi e A. rufitarsus apresentam o bordo dorsal com um par de áreas intumescidas laterais ao segmento X; o urotergito VII com depressões estreitas e rasas que delimitam a base do processo mediano; e a face posterior do segmento $\mathrm{X}$ com carenas laterais bem desenvolvidas.

Antiteuchus rufitarsus Rolston, 1993

(Figs. 55-61, 302)

Antiteuchus (Antiteuchus) rufitarsus Rolston, 1993: 109 (chave), $113-$ 115, figs. 19-22. 7,4 .

Medidas do holótipo: comprimento total- 11,0; largura total-

Superfície dorsal com pontuação densa geralmente recoberta por linhas sinuosas e manchas, coloração variegada. Segmentos antenais I e II amarelo-escuros com manchas escuras. Segmento III com 2/3 basal amarelo com manchas escuras, 1/3 apical negro. Segmentos IV $+\mathrm{V}$, coloração amareloescura com um anel largo e mediano castanho-escuro. Segmentos antenais em ordem crescente de comprimento: I; II; III; IV e V fundidos.

Ápice do escutelo atingindo o final do segmento VII. Ventralmente tórax sem pontuação negra. Mesopleura com um amplo calo amarelo. Fêmures e tíbias amarelo-escuros com manchas castanho-escuras. Tarsos avermelhados. Conexivo alternando áreas escuras nas regiões intersegmentares com amarelas. Coloração dorsal do abdome castanho-escuro e ventral amarela. Região calosa interna aos espiráculos inconspícua. Urotergito VII com as depressões que delimitam a base do processo mediano estreitas e rasas. Processo mediano do urotergito VII pouco desenvolvido, formado apenas por uma convexidade da margem posterior (fig. 55).

Pigóforo amarelo-escuro. Bordo dorsal com um par de áreas intumescidas laterais ao segmento $\mathrm{X}$ e projeções dentiforme (figs. 56, 58). Processo látero-dorsal inconspícuo devido ao intumescimento de toda região lateral, mas a textura, presença de pêlos e uma pequena elevação na base de cada ângulo póstero-lateral do pigóforo assinalam tal região. Elevações do bordo ventral arredondadas e recobertas por uma fileira de pêlos concentrados no ápice, diminuindo de densidade ao longo da margem interna; região mediana côncava, sem uma projeção retangular (fig. 57). Bordo com projeção membranosa limitada à base das elevações arredondadas. Ângulo pósterolateral do pigóforo sub-retangular em vista lateral, cerca de quatro vezes mais longo que largo em vista lateral, e abruptamente inclinado para o lado interno na metade posterior. Ápice truncado com uma aba transversal muito achatada na margem. Face lateral interna levemente convexa; face dorsal sinuosa e com uma mancha castanho-escura no 1/ 3 posterior; face ventral e lateral externa convexa.

Cabeça do parâmero (figs. 59-61) com o lobo dorsal extremamente desenvolvido, arredondado e recoberto por seis ou sete carenas transversais bem desenvolvidas, apresentando também uma projeção ventral que se estreita progressivamente em direção ao ápice. Lobo lateral achatado ântero-

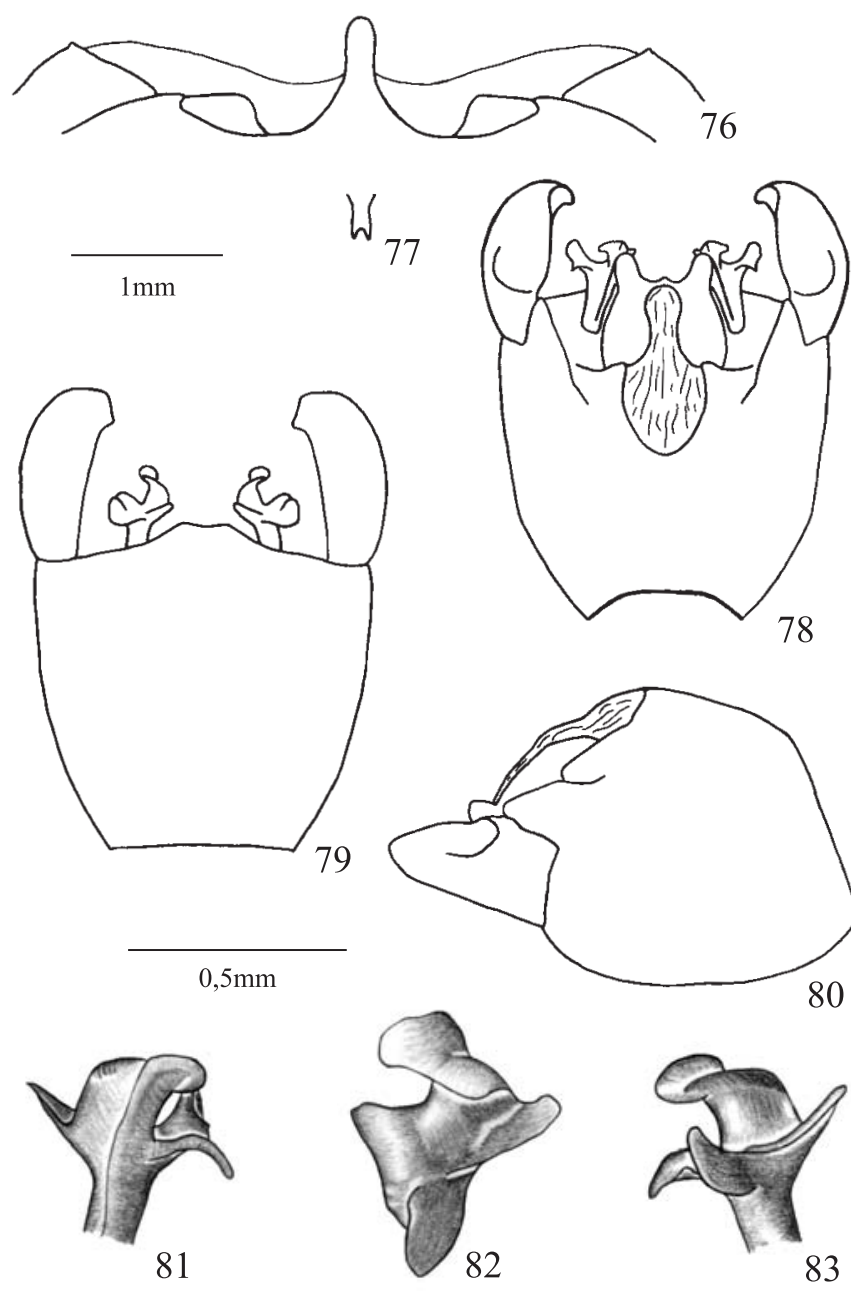

Figs. 76-83. Antiteuchus punctissimus. 76, Processo mediano do tergito VII; 77, Ápice do processo mediano em vista posterior; 78-80, Pigóforo em vistas dorsal, ventral e lateral, respectivamente; 81-83, Parâmero em vistas dorsal, posterior e ventral, respectivamente.

posteriormente e composto por dois processos sobrepostos, digitiformes, alongados e com ápice dirigido dorsalmente, sendo o inferior mais longo e curvado no ápice, e o superior curvado na metade distal.

Segmento X semicilíndrico, tubérculos muito desenvolvidos, retos, paralelos, achatados lateralmente, dirigidos dorso-posteriormente e implantados obliquamente sobre o segmento X (figs. 56, 58). Face posterior com carenas laterais bem desenvolvidas, perpendicular em relação ao plano frontal do pigóforo e com a área intumescida mediana bem desenvolvida. Área membranosa dorsal terminando na base dos tubérculos.

Holótipo macho. "Venezuela, T. F. Amazonas, Cerro da Neblina, Base Camp. 140 M 0 $50^{\prime} \mathrm{N}$ 6699'W, 24-Nov.-1 Dec, 1984, R. L. Brown" (BMNH). Examinado.

Distribuição: VENEZUELA, Amazonas: Cerro da Neblina. 
Comentários: Espécie conhecida apenas pelo holótipo. Esta espécie pode ser reconhecida por apresentar o lobo dorsal do parâmero alongado e recoberto por seis ou sete carenas transversais bem desenvolvidas; pelos tubérculos do segmento $\mathrm{X}$ alongados, retos, paralelos e achatados lateralmente.

\section{Grupo A. peruensis}

(Figs. 62-160, 303-304)

Corpo ovalado, achatado dorso-ventralmente, de cor amarela a castanho-clara e brilhante. Pontuação dorsal muito densa, distribuída em linhas sinuosas e transversais recobertas por faixas castanhas a castanho-escuras. Tais faixas podem cobrir quase totalmente a superfície dorsal do corpo, tornando o exemplar escuro.

Jugas com as margens externas negras. Pontuação do $1 / 3$ basal do pronoto mais rasa e de menor tamanho que nos $2 / 3$ distais. Hemiélitro atingindo a metade distal ou ultrapassando a margem do conexivo VII; pontuação regularmente distribuída. Escutelo com ápice arredondado e atingindo a metade distal do segmento VII. Ventralmente o tórax é amarelo com manchas castanhas a castanho-escuras de tamanho variável, estas manchas recobrem os pontos e podem escurecer quase toda superfície ventral; ocorrem áreas com manchas negras na margem posterior da metapleura e eventualmente sobre o pronoto ventral e mesopleura. Margem lateral do pronoto ventral sem pontuação e com manchas mais claras que no restante do segmento. Área evaporatória castanha. Ruga ostiolar amarela. Mesopleura com um pequeno calo amarelopálido próximo à margem lateral. Metapleura com um grande calo amarelo junto à margem lateral. Coxas, trocânteres e tarsos amarelos a castanhos e imaculados. Fêmures e tíbias amarelos a negros, dependendo da concentração e cor das manchas que os recobrem. Tíbias com pêlos mais curtos que o diâmetro do segmento.

Coloração dorsal do abdome castanho-escura. Conexivo amarelo a amarelo-escuro, pontos recobertos por manchas castanhas e interligados por faixas de mesma cor que variam de densidade, podendo ocupar todo segmento; áreas intersegmentares com manchas negras; margem lateral externa amarela ou não. Face ventral do abdome amarela a castanhoclara e recoberta por manchas castanhas que diminuem de densidade da margem lateral em direção à região mediana. Ângulos póstero-laterais de cada segmento geralmente escuros. Pode ou não ocorrer uma faixa lateral escura e de largura variável que engloba os espiráculos; geralmente ocorre uma pequena região sub-calosa e amarela, localizada na lateral interna de cada espiráculo. Urotergito VII sem um par de processos convexos e espessados na margem. Uma linha imaginária tangente à margem posterior do conexivo VII não secciona o ângulo póstero-lateral do urotergito VII, com exceção de A. puctissimus e A. amapensis. Margem posterior do processo mediano sem uma lígula membranosa. Membrana do urotergito VII desenvolvida, estendendo-se por toda margem posterior e sem pêlos (figs. 62, 69).

Bordo dorsal do pigóforo sem áreas intumescidas laterais
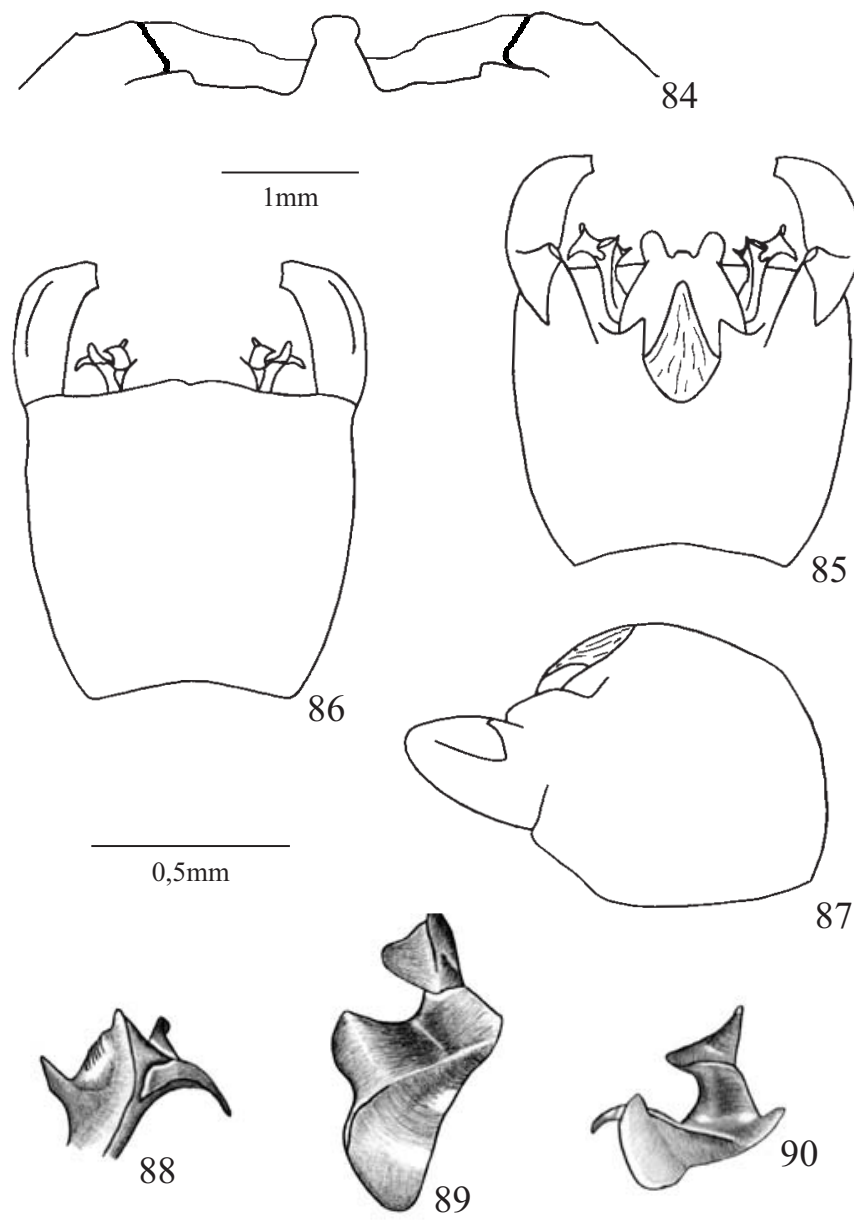

Figs. 84-90. Antiteuchus amapensis sp. nov. 84, Processo mediano do tergito VII; 85-87, Pigóforo em vistas dorsal, ventral e lateral, respectivamente; 88-90, Parâmero em vistas dorsal, posterior e ventral, respectivamente.

ao segmento X. Escavação do bordo dorsal quase ou tão larga quanto profunda (figs. 63, 99). Projeções do bordo dorsal, laterais ao segmento $\mathrm{X}$, dentiformes, com exceção de $A$. confinium, A. mimeticus e $A$. cuspidatus onde elas são arredondadas. Diafragma sem processos membranosos. Ângulos póstero-laterais do pigóforo convergentes (figs. 63, 92). Face lateral e ventral pontuadas, sendo os pontos interligados por faixas castanho-escuras a negras, e apresentando muitos sulcos longitudinais. Ângulo pósterolateral do pigóforo mais longo que a área esclerotizada do segmento X e implantado no plano longitudinal do pigóforo.

Parâmero apresentando a cabeça perpendicular ao seu eixo longitudinal (figs. 67, 110). Margem lateral do parâmero, entre o lobo dorsal e lobo lateral interno, com uma série de carenas curtas e baixas que parecem um enrugamento da parede do parâmero (figs. 66, 102).

Segmento X semicilíndrico, recoberto por pêlos esparsos na face posterior, tubérculos e margem ventral e sem áreas dorso-laterais intumescidas. Tubérculos desenvolvidos. Face posterior sem uma área intumescida na extremidade posterior; 
carenas laterais convergentes em direção ventral, com exceção de A. punctissimus e A. amapensis, onde elas são paralelas; carena média presente (figs. 63, 106).

Comentários: Este grupo inclui as espécies $A$. bartletti, $A$. confinium, A. cuspidatus, A. guianensis, A. mimeticus, A. rideri, A. pallescens, $A$. peruensis, $A$. punctissimus, A. rolstoni, A. doesburgi, A. beckerae, A. amapensis e A. ledeburi. As características compartilhadas pelas espécies do grupo são a presença na margem lateral do parâmero, entre o lobo dorsal e lobo lateral interno, de uma série de carenas curtas e baixas que mais parecem um enrugamento da parede; uma carena longitudinal sobre a face posterior do segmento $\mathrm{X}$; e uma prega sobre a face dorsal de cada ângulo póstero-lateral do pigóforo. O grupo A. peruensis pode ser dividido em dois outros grupos de espécies. O primeiro formado por $A$. confinium, A. mimeticus, A. rideri, A. pallescens, $A$. punctissimus, $A$. doesburgi e $A$. amapensis pode ser facilmente reconhecido pela presença de um dente subapical, associado a uma carena negra, sobre a margem ventral interna de cada ângulo póstero-lateral do pigóforo. $\mathrm{O}$ outro grupo de espécies, formado pelas espécies $A$. bartletti, A. cuspidatus, A. guianensis, A. peruensis, A. rolstoni, A. beckerae e A. ledeburi, pode ser reconhecido pela a margem do urotergito VII com um par de impressões largas e profundas, uma de cada lado da projeção mediana; pela região posterior de cada ângulo póstero-lateral do pigóforo fortemente curvada internamente, embora não obstrua, necessariamente, a visão da taça genital em vista posterior; pela forma sub-retangular do ângulo póstero-lateral do pigóforo em vista lateral; e pela prega da face dorsal do ângulo póstero-lateral do pigóforo descendente. A forma do segmento $\mathrm{X}$ é semelhante a das espécies $A$. confinium, A. mimeticus e A. doesburgi.

\section{Chave para os machos das espécies do grupo $A$. peruensis}

1. Presença de um dente subapical associado a uma carena achatada e negra sobre a margem ventral interna de cada ângulo póstero-lateral do pigóforo (figs. 64, 100)

Ângulo póstero-lateral do pigóforo sem carena ou dente apical, pode ocorrer um tubérculo subapical com a mesma cor e textura da própria margem ventral interna (figs. 142, 149) 8

2(1). Processo látero-dorsal do pigóforo muito desenvolvido e fundido ao $1 / 3$ basal do ângulo póstero-lateral do pigóforo. Ângulo póstero-lateral do pigóforo curto, cerca de 1,5 vezes mais longo que largo em vista lateral. Presença de uma prega ascendente sobre a face dorsal deste ângulo (figs. 63, 72) .... 3

Processo látero-dorsal do pigóforo pouco desenvolvido e não fundido ao ângulo póstero-lateral do pigóforo. Ângulo póstero-lateral do pigóforo longo, cerca de 2 vezes mais longo que largo em vista lateral. Presença de uma prega descendente sobre a face dorsal deste ângulo (figs. 92, 106)

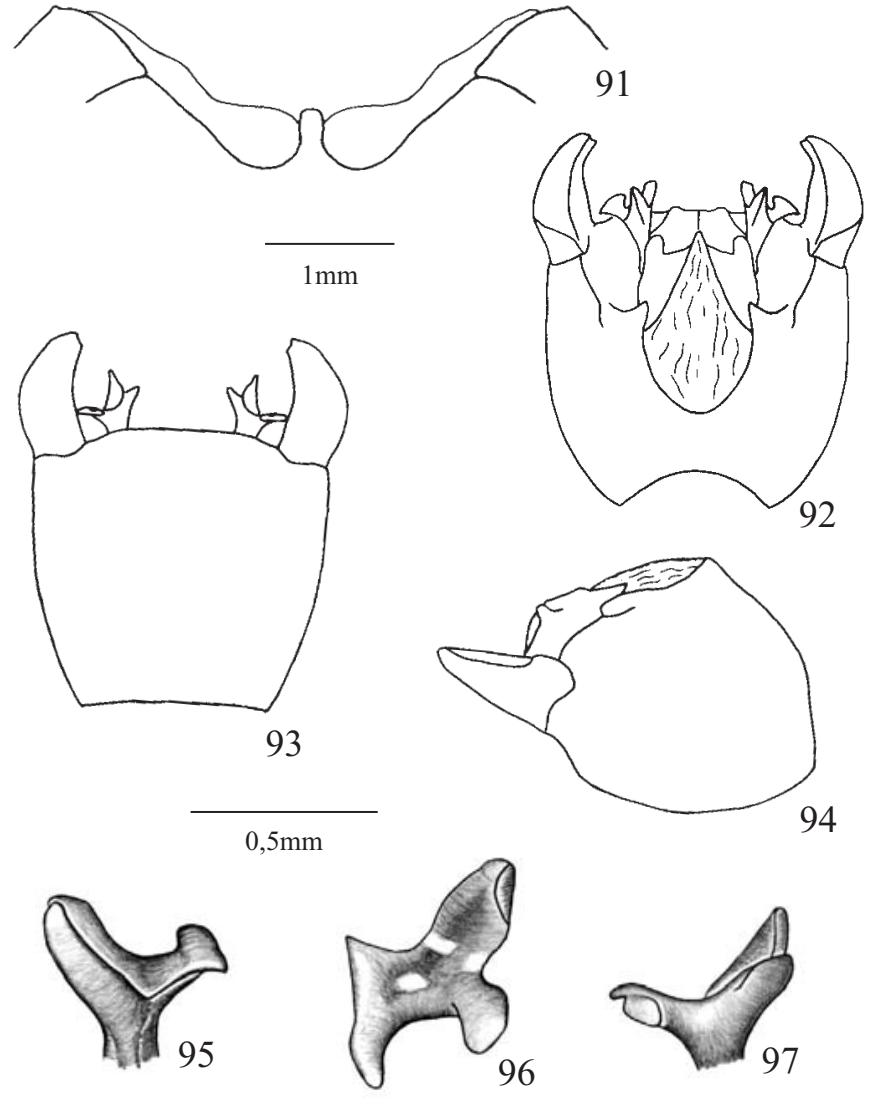

Figs. 91-97. Antiteuchus confinium. 91, Processo mediano do tergito VII; 92-94, Pigóforo em vistas dorsal, ventral e lateral, respectivamente; 95-97, Parâmero em vistas dorsal, posterior e ventral, respectivamente.

3(2). Uma linha imaginária tangente à margem posterior do conexivo VII, não secciona o ângulo póstero-lateral do urotergito VII. Carenas das margens laterais da face posterior do segmento $\mathrm{X}$ convergentes em direção ventral (figs. 63, 70)

Uma linha imaginária tangente à margem posterior do conexivo VII, secciona o ângulo póstero-lateral do urotergito VII e forma uma pequena área membranosa sobre a membrana que percorre o urotergito VII. Carenas das margens laterais da face posterior do segmento X paralelas (figs. 76, 84)

4(3). Margem posterior do processo mediano do urotergito VII curvada ventralmente envolvendo ou não a margem da membrana. Lobo lateral interno do parâmero desenvolvido (figs. 62, 67) ...... A. pallescens

Margem posterior do processo mediano do urotergito VII plana. Lobo lateral interno ausente ou limitado a uma pequena convexidade da parede (figs. 69, 74) ...

A. rideri

5(3). Processo mediano do urotergito VII estreito, digitiforme e fortemente convexo no ápice. Lobo ventral do 
parâmero estreito e quase plano em vista posterior (figs. 76-77, 82) A. punctissimus

Processo mediano do urotergito VII largo e com ápice plano. Lobo ventral do parâmero amplo e côncavo em vista posterior (figs. 84, 89) ..... A. amapensis sp. nov.

6(2). Processo mediano do urotergito VII expandido no ápice, margem posterior sulcada. Carena da margem ventral interna de cada ângulo póstero-lateral do pigóforo restrita ao $1 / 3$ apical (figs. 105)

A. doesburgi sp. nov.

Processo mediano do urotergito VII retangular ou levemente expandido no ápice, margem posterior inteira. Carena de cada ângulo póstero-lateral do pigóforo percorrendo toda margem ventral interna (figs. 91, 98). . .7

7(6). Processo mediano do urotergito VII retangular. Ângulo póstero-lateral do pigóforo triangular em vista lateral. Lobo dorsal do parâmero com uma pequena projeção curvada posteriormente. Carenas entre os lobos dorsal e lateral interno do parâmero quase inconspícuas (figs. 91, 94, 96). A. confinium

Processo mediano do urotergito VII levemente expandido no ápice. Ângulo póstero-lateral do pigóforo subretangular em vista lateral. Lobo dorsal do parâmero curvado posteriormente. Carenas entre os lobos dorsal e lateral interno do parâmero facilmente visíveis (figs. 98, 101-103). A. mimeticus

8(1). Processo mediano do urotergito VII reduzido ao uma convexidade da parede. Lobo lateral interno do parâmero ausente ou fundido ao lobo dorsal. (figs. $112,117)$ A. bartletti

Processo mediano do urotergito VII desenvolvido. Lobo lateral interno do parâmero desenvolvido, podendo ser o maior do parâmero (figs. 119, 126) . ... 9

9(8). Margem posterior do processo mediano do urotergito VII inteira. Processo látero-dorsal do pigóforo muito desenvolvido e parcialmente fundido com a base do ângulo póstero-lateral do pigóforo. Prega da face dorsal do ângulo póstero-lateral do pigóforo ausente (figs. 119, 122) A. guianensis

Margem posterior do processo mediano do urotergito VII sulcada. Processo látero-dorsal do pigóforo desenvolvido ou não e livre em relação à base do ângulo póstero-lateral do pigóforo. Prega da face dorsal do ângulo póstero-lateral do pigóforo presente (figs. 126, 140, 143, 150) 10

10(9). Ápice do processo mediano do urotergito VII expandido no ápice, margem posterior levemente sulcada. Processo látero-dorsal desenvolvido. Ápice de cada ângulo póstero-lateral do pigóforo com um grande processo bicúspide (figs. 126, 127) ....... A. cuspidatus

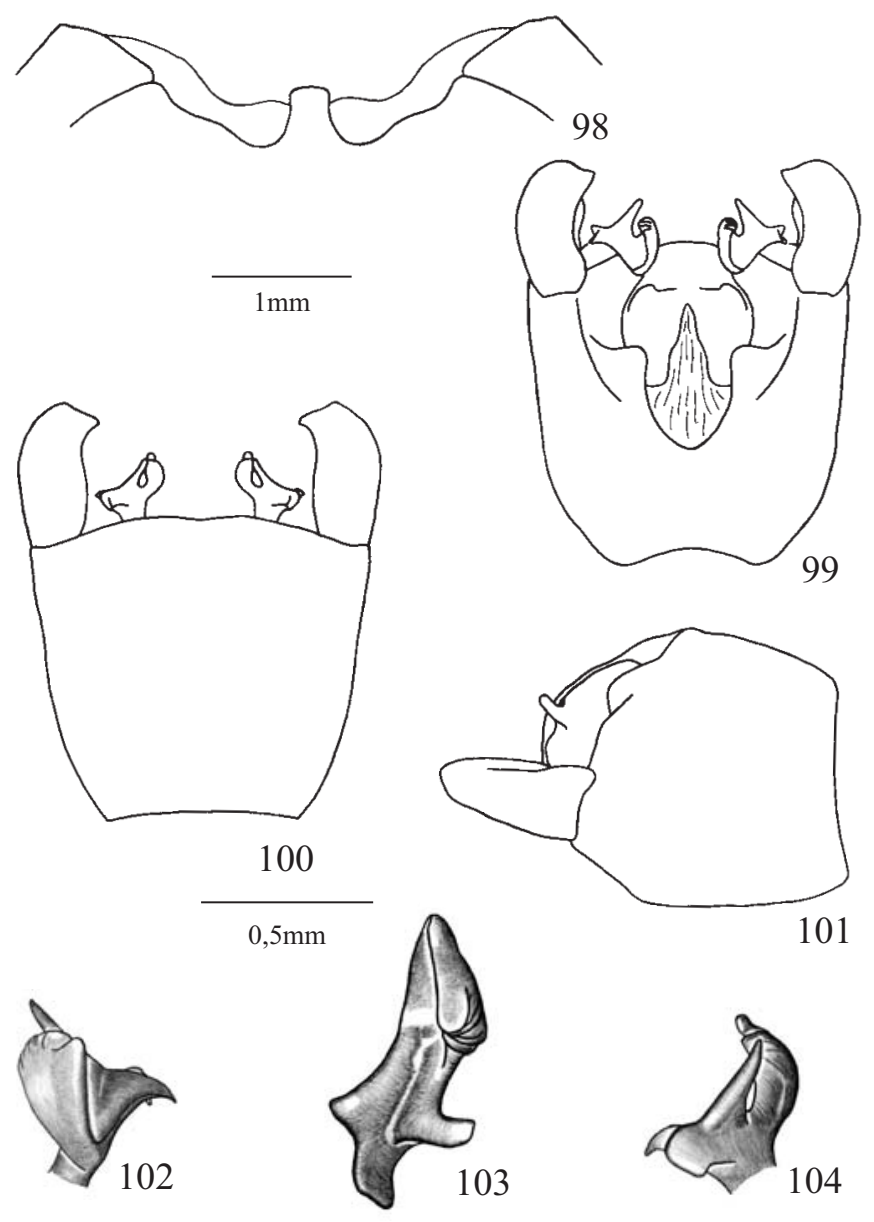

Figs. 98-104. Antiteuchus mimeticus. 98, Processo mediano do tergito VII; 99-101, Pigóforo em vistas dorsal, ventral e lateral, respectivamente; 102-104, Parâmero em vistas dorsal, posterior e ventral, respectivamente.

Ápice do processo mediano do urotergito VII não expandido, margem sulcada. Processo látero-dorsal do pigóforo pouco desenvolvido. Ápice de cada ângulo póstero-lateral do pigóforo truncado e com uma aba transversal pouco achatada (figs. 147, 150) ..

11

11(10). Margem posterior do processo mediano do urotergito VII com um sulco raso e largo, resultando em dois pequenos lobos sobre as laterais. Ângulo pósterolateral do pigóforo sem um tubérculo sobre a margem ventral interna (figs. 133-135) ...... A. ledeburi sp. nov.

Margem posterior do processo mediano do urotergito VII com um sulco profundo, resultando em dois grandes lobos sobre as laterais. Ângulo pósterolateral do pigóforo com um tubérculo sobre a margem ventral interna (figs. 147, 149) 12

12(11). Bordo ventral com duas saliências recoberta por pêlos. Ângulo póstero-lateral do pigóforo com um pequeno tubérculo próximo ao ápice. Lobo ventral do parâmero 
ausente ou reduzido a uma pequena convexidade da parede (figs. 148-149, 152). 13

Bordo ventral sem saliências recobertas por pêlos. Ângulo póstero-lateral do pigóforo com um grande tubérculo próximo ao ápice. Lobo ventral do parâmero espiniforme (figs. 142, 145) ....... A. beckerae sp. nov.

13(12). Ângulo póstero-lateral do pigóforo muito largo em vista dorsal, ápice com aba transversal estreita. Lobo dorsal do parâmero estreito em vista posterior. Lobo lateral interno estreito, reto e com ápice expandido (figs. 148, 152-153) A. peruensis

Ângulo póstero-lateral do pigóforo mais estreito que na espécie anterior, ápice com aba transversal larga e direcionada posteriormente. Lobo dorsal do parâmero largo em vista posterior. Lobo lateral interno largo, curvado e com ápice arredondado (figs. 155, 159-160) A. rolstoni

Antiteuchus pallescens Stål, 1868

(Figs. 62-68, 303)

Antiteuchus pallescens Stål, 1868: 18.

Antiteuchus (Antiteuchus) pallescens; Ruckes, 1964: 101; Rolston, 1993: 109, 121-122 (determinação de lectótipo e paralectótipos), figs. 45-48.

Antiteuchus (Antiteuchus) varians Ruckes, 1964: 85 (chave), 91-92, figs. 56-59; Rolston, 1993: 110 (chave), 128, figs. 60-62. SIN. NOV.

Medidas (n=20): comprimento total- 11,3-13,1; largura total7,7-8,2.

Segmentos antenais I e II amarelos a amarelo-escuros com manchas escuras. Segmentos III e IV negros. Segmento V amarelo. Segmentos em ordem crescente de comprimento: I; II; III; IV e V subiguais.

Urotergito VII com um par de impressões largas, profundas e laterais a projeção mediana. Processo mediano do urotergito VII bem desenvolvido, parte livre curta, larga, convexa transversalmente e curvada ventralmente, ápice levemente expandido, margem posterior inteira, curvada ventralmente envolvendo ou não a margem da membrana. Margem posterior do processo mediano praticamente coincidindo com a margem da membrana (fig. 62).

Pigóforo amarelo-escuro e com um tufo de pêlos longos na lateral, junto ao ângulo póstero-lateral do pigóforo. Processo látero-dorsal muito desenvolvido, formado por uma elevação da parede do pigóforo achatada lateralmente, e fundida com o $1 / 3$ basal do ângulo póstero-lateral do pigóforo (fig. 65). Projeções do bordo dorsal, laterais ao segmento X, não avançam em direção aos tubérculos deste (fig. 63). Bordo ventral trapezoidal, largo, plano, margem dobrada posteriormente em ambos os 1/3 laterais, margem superior reta ou levemente côncava e tão larga quanto à extremidade do segmento X (fig. 64). Superfície ventral do pigóforo, logo abaixo do bordo ventral, apresentando uma área mediana côncava com uma protuberância ampla e baixa no centro, recoberta por

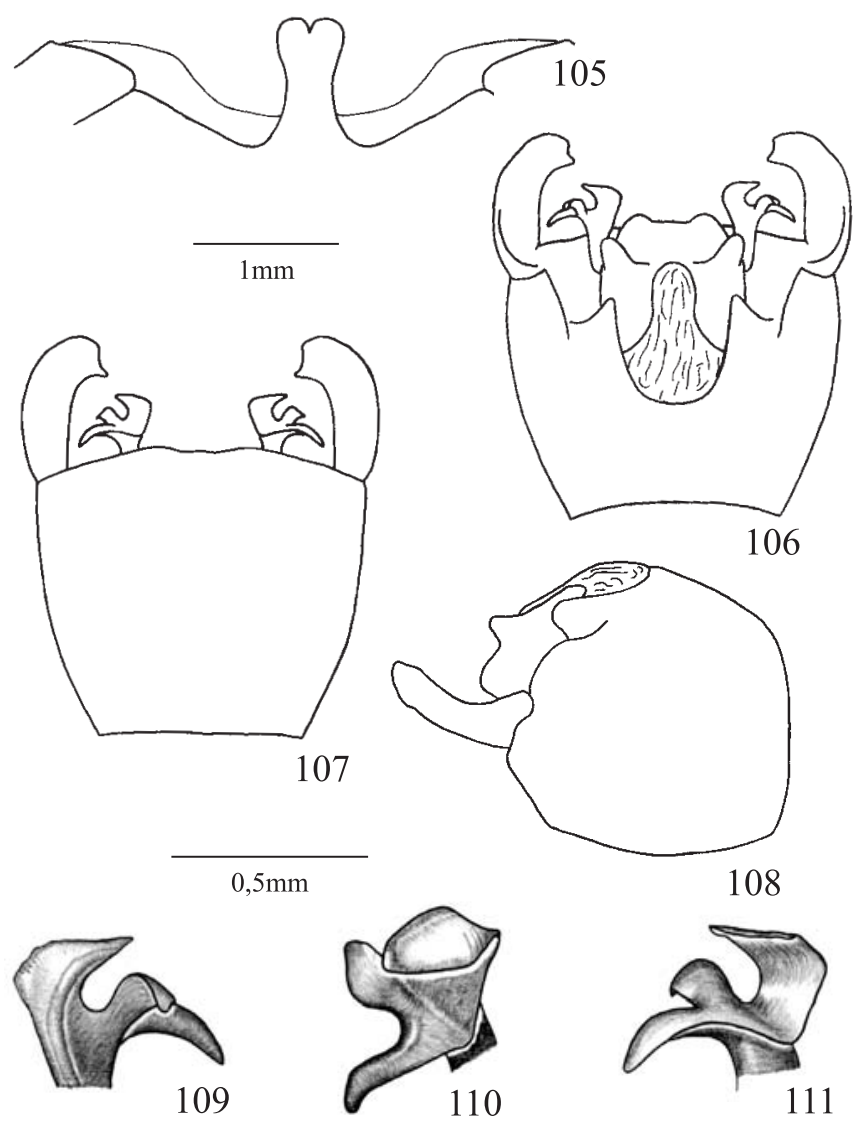

Figs. 105-111. Antiteuchus doesburgi sp. nov. 105, Processo mediano do tergito VII; 106-108, Pigóforo em vistas dorsal, ventral e lateral, respectivamente; 109-111, Parâmero em vistas dorsal, posterior e ventral, respectivamente.

pêlos esparsos e margeada por uma larga faixa castanha. Ângulo póstero-lateral do pigóforo, ogival, cerca de 1,5 vezes mais longo que largo, em vista lateral, e não obstruindo a visão da taça genital em vista posterior. Face interna deste ângulo levemente côncava e apresentando uma carena negra na margem ventral interna, que inicia próximo à base e estende-se até o ápice do ângulo póstero-lateral. Associado a tal carena ocorre um dente achatado, negro, dirigido lateralmente e localizado próximo ao ápice do ângulo. Face dorsal convexa com exceção de uma grande depressão mediana localizada após uma prega em aclive, observando-a da margem externa para interna; 1/4 apical com uma grande mancha escura. Face ventral levemente convexa.

Cabeça do parâmero (figs. 66-68) composta por 4 lobos: Dorsal (ld) amplo, delgado, curvado lateralmente e parcialmente dividido em duas partes, uma superior e outra inferior, sendo a inferior mais curvada que a superior; parte inferior com uma série de carenas baixas (ca); carena dorsal alta e terminando próximo à margem da parte superior do lobo. Lobo lateral interno (li) desenvolvido, triangular e dirigido pósterolateralmente. Lobo lateral externo (le) desenvolvido, amplo, sub-retangular, delgado e curvado anteriormente. Lobo ventral 
(lv) arredondado, côncavo, torcido, quase perpendicular aos outros lobos; sua margem posterior apresenta-se levemente rebatida lateralmente e projeta-se sobre o corpo do parâmero, sob a forma de uma pequena carena negra, podendo ou não fundir-se a margem do lobo lateral interno.

Segmento X com tubérculos digitiformes, dirigidos dorsoposteriormente e implantados obliquamente sobre o segmento $\mathrm{X}$ (fig. 63). Face posterior plana, perpendicular ao plano frontal do pigóforo; carenas laterais bem desenvolvidas; crista mediana percorrendo toda face. Área membranosa dorsal terminando entre os tubérculos.

A. pallescens: Lectótipo macho. "pallescens Stål" "America Meridionalis, Schimidt, Dom. Schestadt", "Lectotype Antiteuchus pallescens Stål” (ZMUC). Examinado.

A. varians: Holótipo macho. "Tumatumari, Potaro Rios, June-241927, Brit. Guiana” (AMNH). Examinado.

Distribuição: Guiana, Essequibo: Tumatumari-Potaro River. Suriname, Nickerie: Avanavero, Sipaliwini. Brasil, Amazonas: Cachoeira Balbina, Manaus, Borba; Pará: Benevides, Belém, Jacareacanga, Castanhal.

Comentários: Os exemplares examinados pertencem às coleções do AMNH, INPA, MCNZ, MPEG, NHRS, RMNH, MNRJ e UFRG. Esta espécie pode ser identificada pelo processo mediano do urotergito VII com o ápice levemente expandido e margem posterior curvada ventralmente envolvendo ou não a margem da membrana; pelas seguintes características do parâmero: lobo dorsal amplo e com região apical dividida em duas partes; carena dorsal terminando próximo à margem da parte superior do lobo; lobo lateral externo amplo e subretangular; lobo ventral arredondado e côncavo, com a margem posterior levemente rebatida lateralmente, projetando-se sobre o parâmero sob a forma de uma pequena carena negra que pode ou não fundir-se a margem do lobo lateral interno.Compartilha com $A$. rideri as carenas laterais da face posterior do segmento $\mathrm{X}$ convergentes em direção ventral. Assemelha-se a $A$. punctissimus e $A$. amapensis pela forma triangular do lobo dorsal do parâmero. Compartilha com $A$. rideri, $A$. punctissimus e $A$. amapensis a presença no urotergito VII de um par de impressões largas, profundas e laterais a projeção mediana; pigóforo com um tufo de pêlos longos na lateral, junto ao ângulo póstero-lateral do pigóforo; processo látero-dorsal muito desenvolvido e avançando sobre o $1 / 3$ basal do ângulo póstero-lateral do pigóforo, fundindo-se totalmente a ele; face dorsal do ângulo póstero-lateral com uma prega em aclive, observando-se da margem externa para interna; lobo ventral do parâmero arredondado e torcido, ficando quase perpendicular aos outros lobos; tubérculos do segmento $\mathrm{X}$ bem desenvolvidos e cilíndricos; face posterior do segmento X plana e perpendicular ao plano frontal do pigóforo.

Antiteuchus rideri Rolston, 1993

(Figs. 69-75, 303)

Antiteuchus (Antiteuchus) rideri Rolston, 1993: 110 (chave), 122126, figs. 66-71.

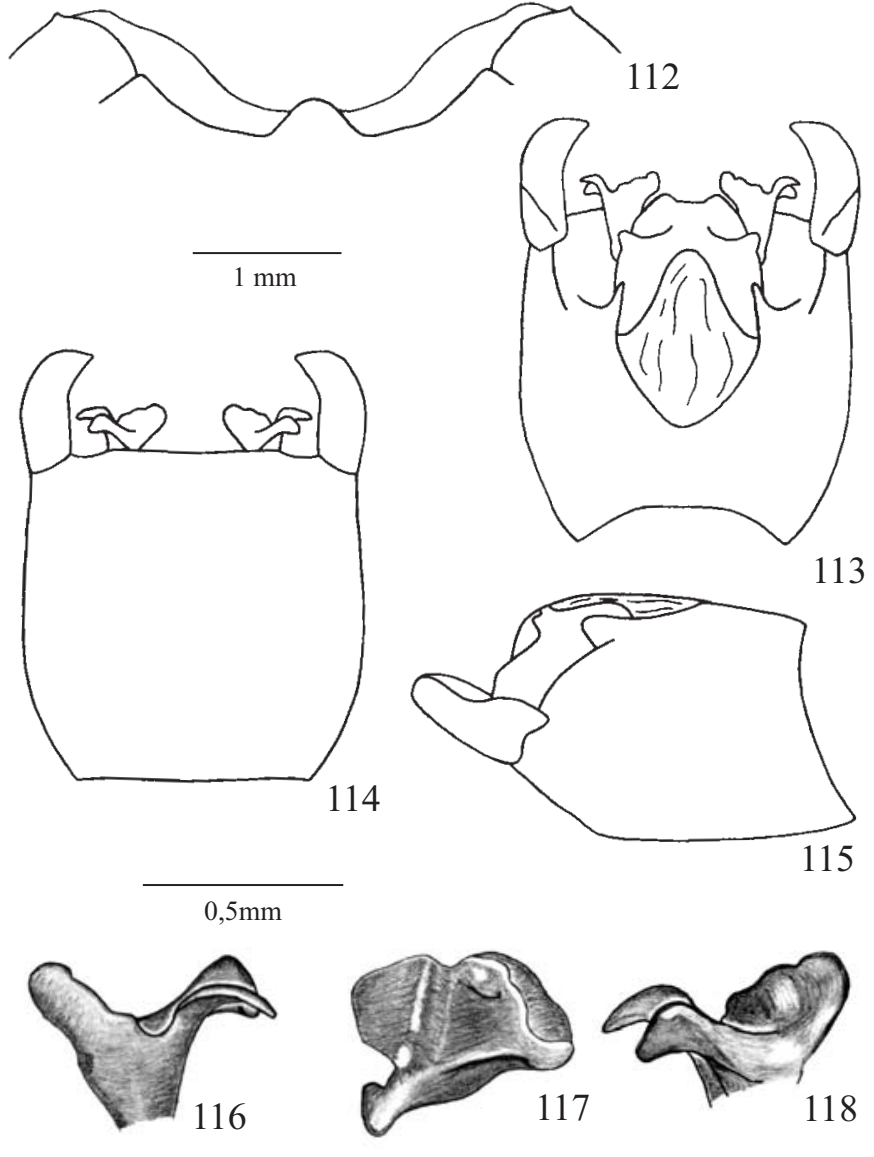

Figs. 112-118. Antiteuchus bartletti. 112, Processo mediano do tergito VII; 113-115, Pigóforo em vistas dorsal, ventral e lateral, respectivamente; 116-118, Parâmero em vistas dorsal, posterior e ventral, respectivamente.

Medidas $(\mathrm{n}=20)$ : comprimento total- 11,5-13,0; largura total- 7,4-8,0.

Segmentos antenais I e II amarelos com manchas escuras. Segmentos III e IV negros. Segmento V amarelo. Segmentos em ordem crescente de comprimento: I e II subiguais; III; IV e $\mathrm{V}$ subiguais.

Urotergito VII com um par de impressões largas, profundas e laterais a projeção mediana. Processo mediano do urotergito VII bem desenvolvido, parte livre curta, larga, pouco convexa transversalmente e curvada ventralmente; ápice expandido, margem posterior inteira e plana. Margem posterior do processo mediano ultrapassando pouco a margem da membrana; apenas a parte expandida ultrapassa a membrana (fig. 69).

Pigóforo amarelo-escuro e com um tufo de pêlos longos na lateral, junto ao ângulo póstero-lateral do pigóforo. Processo látero-dorsal desenvolvido, formado por uma elevação da parede do pigóforo achatada lateralmente, e fundida com o 1/3 basal do ângulo póstero-lateral do pigóforo (fig. 72). Projeções do bordo dorsal, laterais ao segmento X, dentiformes e não avançando em direção aos tubérculos deste (fig. 70). Bordo ventral trapezoidal, largo, plano, margem 
dobrada posteriormente em ambos os 1/3 laterais, margem superior reta ou levemente côncava e tão larga quanto a extremidade do segmento X (fig. 71). Superfície ventral do pigóforo, logo abaixo do bordo ventral, apresentando uma área mediana côncava com uma protuberância ampla e baixa no centro, recoberta por pêlos esparsos e margeada por uma larga faixa castanha. Ângulo póstero-lateral do pigóforo ogival, cerca de 1,5 vezes mais longo que largo, em vista lateral, e não obstruindo a visão da taça genital, em vista posterior. Face interna deste ângulo levemente côncava e apresentando uma carena negra na margem ventral interna, que inicia próximo à base e estende-se até o ápice do ângulo póstero-lateral. Associado a tal carena ocorre um dente achatado, negro, levemente curvado anteriormente e localizado próximo ao ápice do ângulo. Face dorsal convexa com exceção de uma grande área mediana plana localizada após uma prega em aclive, observando-a da margem externa para interna; 1/3 apical com uma grande mancha castanho-escura. Face ventral levemente convexa.

Cabeça do parâmero (figs. 73-75) composta por 4 lobos: Dorsal amplo, delgado, inteiro, curvado ventro-lateralmente e com as margens um pouco rebatidas dorsalmente; carena dorsal alta prolongando-se pela margem lateral do lobo. Lobo lateral interno pouco desenvolvido, triangular e delgado ou quase inconspícuo, não passando de uma pequena convexidade da parede. Lobo lateral externo desenvolvido, amplo, triangular, delgado, e curvado anteriormente. Lobo ventral arredondado, levemente côncavo, torcido, estando quase perpendicular aos outros lobos; sua margem posterior apresenta-se rebatida lateralmente e projeta-se pouco sobre o corpo do parâmero, sob a forma de uma pequena carena negra, mas continua-se como uma dobra da parede do parâmero até a base do lobo lateral interno.

Segmento X com tubérculos desenvolvidos, digitiformes, dirigidos dorso-posteriormente e implantados obliquamente sobre o segmento X (fig. 70). Face posterior plana, perpendicular ao plano frontal do pigóforo; carenas laterais bem desenvolvidas e convergentes; crista mediana percorrendo toda face. Área membranosa dorsal terminando entre os tubérculos.

Holótipo macho. "Santarém, July 1919, S. M. Krages Acc. 6324" (BMNH). Examinado.

Distribuição: Brasil, Amazonas: Manaus (Rod. ManausItacoatiara Km 30); Pará: Soure (ilha de Marajó), Castanhal, Belém, Santarém, Tomé-Açú, Belterra, Paragominas, Piratuba, Ilha Grande, Altamira e Medicilândia (Rod. Transamazônica Kms 70/90/97); Rondônia: Ouro Preto d'Oeste.

Comentários: Os exemplares examinados pertencem às coleções do BMNH, FIOC, UFRRJ, INPA, MPEG, MZSP, UFRG e NMNH. Esta espécie pode ser caracterizada pelo lobo dorsal do parâmero inteiro; pela carena dorsal alta prolongando-se pela margem lateral do lobo; pelo lobo lateral interno pouco desenvolvido e triangular ou quase inconspícuo; pelo lobo ventral com a margem posterior rebatida lateralmente,

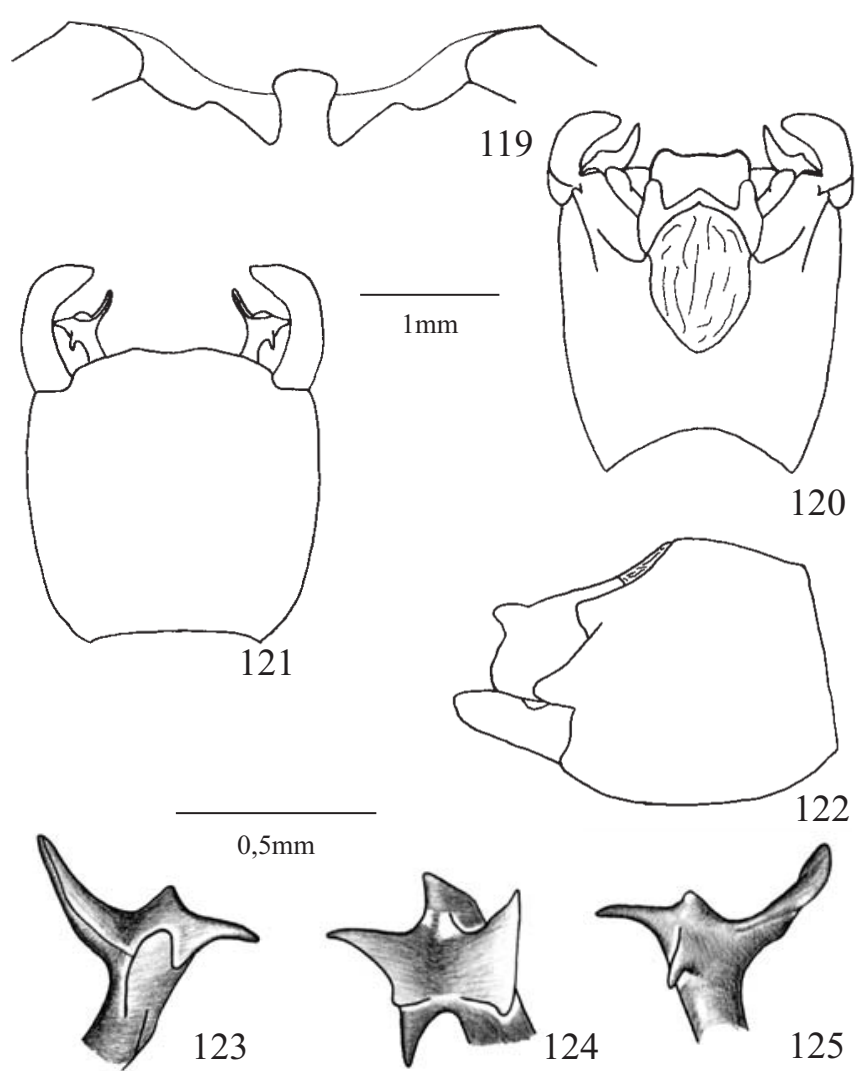

Figs. 119-125. Antiteuchus guianensis. 119, Processo mediano do tergito VII; 120-122, Pigóforo em vistas dorsal, ventral e lateral, respectivamente; 123-125, Parâmero em vistas dorsal, posterior e ventral, respectivamente.

projetando-se pouco sobre o corpo do parâmero sob a forma de uma pequena carena negra. A. rideri e $A$. amapensis têm como característica comum o processo mediano do urotergito VII curto e largo, ápice expandido e ultrapassando pouco a membrana. Esta espécie compartilha com A. punctissimus e $A$. amapensis o lobo lateral externo do parâmero amplo, triangular e curvado anteriormente.

Antiteuchus punctissimus Ruckes, 1964

(Figs. 76-83, 303)

Antiteuchus (Antiteuchus) punctissimus Ruckes, 1964: 84 (chave), 9294, figs. 60-62; Rolston, 1993: 110 (chave), 127-128, figs. 57-59.

Medidas ( $\mathrm{n}=20)$ : comprimento total- 9,9-12,3; largura total6,9-7,7.

Segmentos antenais I e II amarelos com manchas escuras. Segmento III com o 1/3 basal negro e o restante amarelo com manchas escuras. Segmento IV negro com um anel basal largo variando do amarelo ao castanho. Segmento $\mathrm{V}$ amarelo a castanho com a metade distal mais escura que o restante. Segmentos em ordem crescente de comprimento: I e II subiguais; III; IV e V subiguais.

Uma linha imaginária tangente à margem posterior do 
conexivo VII, secciona o ângulo póstero-lateral do urotergito VII; associada a esta projeção está uma segunda área membranosa localizada sobre a membrana que percorre a margem posterior. Urotergito VII com um par de impressões largas, profundas e laterais a projeção mediana. Processo mediano do urotergito VII bem desenvolvido, parte livre longa, digitiforme, fortemente convexa transversalmente e curvada ventralmente; ápice expandido e com a margem posterior inteira, devido à convexidade acentuada do processo a parte expandida do ápice fica dirigida ventralmente não permitindo a observação em vista dorsal (fig. 77). Margem posterior do processo mediano ultrapassando muito a margem da membrana, cerca de duas vezes mais longo (fig. 76).

Pigóforo amarelo-escuro e com um tufo de pêlos longos na lateral, junto ao ângulo póstero-lateral do pigóforo. Processo látero-dorsal desenvolvido, formado por uma elevação da parede do pigóforo achatada lateralmente, e fundida com o $1 / 3$ basal do ângulo póstero-lateral do pigóforo (fig. 80). Projeções do bordo dorsal, laterais ao segmento X, não avançam em direção aos tubérculos deste (fig. 78). Bordo ventral trapezoidal, largo, plano, margem dobrada posteriormente em ambos os 1/3 laterais, margem superior reta ou levemente côncava e tão larga quanto a extremidade do segmento X (fig. 79). Superfície ventral do pigóforo, logo abaixo do bordo ventral, apresentando uma área mediana côncava com uma protuberância ampla e baixa no centro, recoberta por pêlos esparsos e margeada por uma larga faixa castanha. Ângulo póstero-lateral do pigóforo, ogival, cerca de 1,6 vezes mais longo que largo, em vista lateral, e não obstruindo a visão da taça genital, em vista posterior. Face interna deste ângulo levemente côncava e apresentando uma carena negra na margem ventral interna, que inicia próximo à base e estendese até o ápice do ângulo póstero-lateral. Associado a esta carena, ocorre um dente achatado, negro, curvado anteriormente e localizado junto ao ápice do ângulo. Face dorsal convexa com exceção de uma grande depressão mediana localizada após uma prega em aclive, observando-a da margem externa para interna; apresenta ainda uma grande mancha escura no 1/4 apical. Face ventral levemente convexa.

Cabeça do parâmero (figs. 81-83) composta por 4 lobos: Dorsal amplo, inteiro, delgado, curvado ventro-lateralmente e expandido no ápice; carena dorsal alta projetando-se sobre a área expandida do lobo onde dobra-se lateralmente atingindo a margem. Lobo lateral interno desenvolvido, triangular, delgado e dirigido póstero-lateralmente. Lobo lateral externo reduzido, triangular, delgado, dirigido ântero-lateralmente e com uma pequena projeção junto ao lobo ventral. Lobo ventral arredondado, quase plano, levemente torcido, estando quase perpendicular aos outros lobos; sua margem posterior apresenta-se levemente rebatida lateralmente e projeta-se pouco sobre o corpo do parâmero, sob a forma de uma pequena carena negra.

Segmento X com tubérculos digitiformes, dirigidos posteriormente e implantados transversalmente sobre o segmento X (fig. 78). Margem lateral expandida formando uma borda que inicia na base do tubo e prolonga-se até a base dos

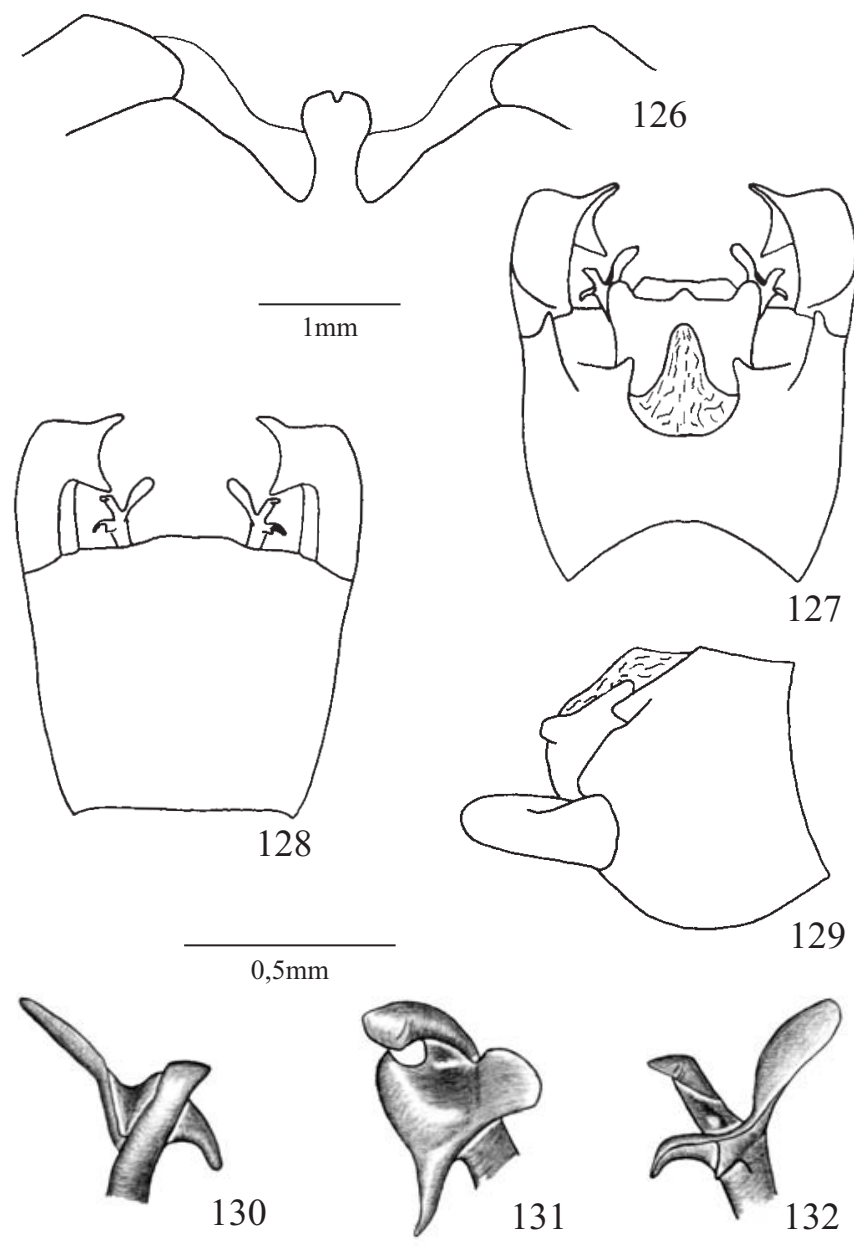

Figs. 126-132. Antiteuchus cuspidatus. 126, Processo mediano do tergito VII; 127-129, Pigóforo em vistas dorsal, ventral e lateral, respectivamente; 130-132, Parâmero em vistas dorsal, posterior e ventral, respectivamente.

tubérculos. Face posterior plana, perpendicular ao plano frontal do pigóforo, com carenas laterais bem desenvolvidas e paralelas; crista mediana percorrendo toda face. Área membranosa dorsal terminando entre os tubérculos.

Holótipo macho. "Para, Dr. Churchill, 1902-260" (BMNH). Examinado.

Distribuição: Brasil, Pará: Belém, Castanhal, Óbidos, Acará, Tomé-Açú.

Comentários: Os exemplares examinados pertencem às coleções do BMNH, MPEG, MNRJ, RMNH e UFRG. Esta espécie é facilmente reconhecida pelo processo mediano do urotergito VII bem desenvolvido, digitiforme e fortemente convexo transversalmente; pelo ápice e fortemente convexo, seguindo a forma digitiforme do processo quando observado em vista dorsal; pelo lobo dorsal do parâmero expandido no ápice; pela carena dorsal do parâmero alta projetando-se sobre a área expandida do lobo onde se dobra lateralmente atingindo a margem. A. punctissimus compartilha com A. amapensis o seccionamento do ângulo póstero-lateral do urotergito VII por 
uma linha imaginária tangente à margem posterior do conexivo VII e carenas laterais da face posterior do segmento X paralelas; presença de uma segunda área membranosa localizada sobre a membrana que percorre a margem posterior.

\section{Antiteuchus amapensis sp. nov.}

(Figs. 84-90, 303)

Etimologia. Referência ao local de coleta dos exemplares conhecidos.

Medidas $(n=8)$ : comprimento total-10,3-11,2; largura total$6,6-6,9$

Segmentos antenais I e II amarelos com manchas escuras. Segmento III com o 1/3 basal negro e o restante amarelo com manchas escuras. Segmento IV negro com um anel basal largo variando do amarelo ao castanho. Segmento V amarelo a castanho com a metade distal mais escura que o restante. Segmentos em ordem crescente de comprimento: I e II subiguais; III; IV e V subiguais.

Uma linha imaginária tangente à margem posterior do conexivo VII, secciona o ângulo póstero-lateral do urotergito VII; associada a esta projeção está uma segunda área membranosa localizada sobre a membrana que percorre a margem posterior. Urotergito VII com um par de impressões largas, profundas e laterais a projeção mediana. Processo mediano do urotergito VII bem desenvolvido, parte livre larga, curta, curvada ventralmente e levemente convexa transversalmente; ápice expandido e com a margem posterior inteira. Margem posterior do processo mediano ultrapassando pouco a margem da membrana, apenas a parte expandida ultrapassa a membrana (fig. 84).

Pigóforo amarelo-escuro e com um tufo de pêlos longos na lateral, junto ao ângulo póstero-lateral do pigóforo. Processo látero-dorsal desenvolvido, formado por uma elevação da parede do pigóforo achatada lateralmente, e fundida com o 1/3 basal do ângulo póstero-lateral do pigóforo (fig. 87). Projeções do bordo dorsal, laterais ao segmento X, não avançando em direção aos tubérculos deste (fig. 85). Bordo ventral trapezoidal, largo, plano, margem dobrada posteriormente em ambos os 1/3 laterais, margem superior reta ou levemente côncava e tão larga quanto a extremidade do segmento X (fig. 86). Superfície ventral do pigóforo, logo abaixo do bordo ventral, apresentando uma área mediana côncava com uma protuberância ampla e baixa no centro da concavidade, recoberta por pêlos esparsos e margeada por uma larga faixa castanha. Ângulo póstero-lateral do pigóforo ogival, cerca de 1,4 vezes mais longo que largo, em vista lateral, e não obstruindo a visão da taça genital, em vista posterior. Face interna deste ângulo levemente côncava e apresentando uma carena negra na margem ventral interna, que inicia próximo à base e estende-se até o ápice do ângulo póstero-lateral. Associado a tal carena ocorre um dente achatado, negro, curvado anteriormente e localizado junto ao ápice do ângulo. Face dorsal convexa com exceção de uma grande depressão mediana localizada após uma prega em aclive, observando-a da margem externa para interna; ocorre ainda uma grande

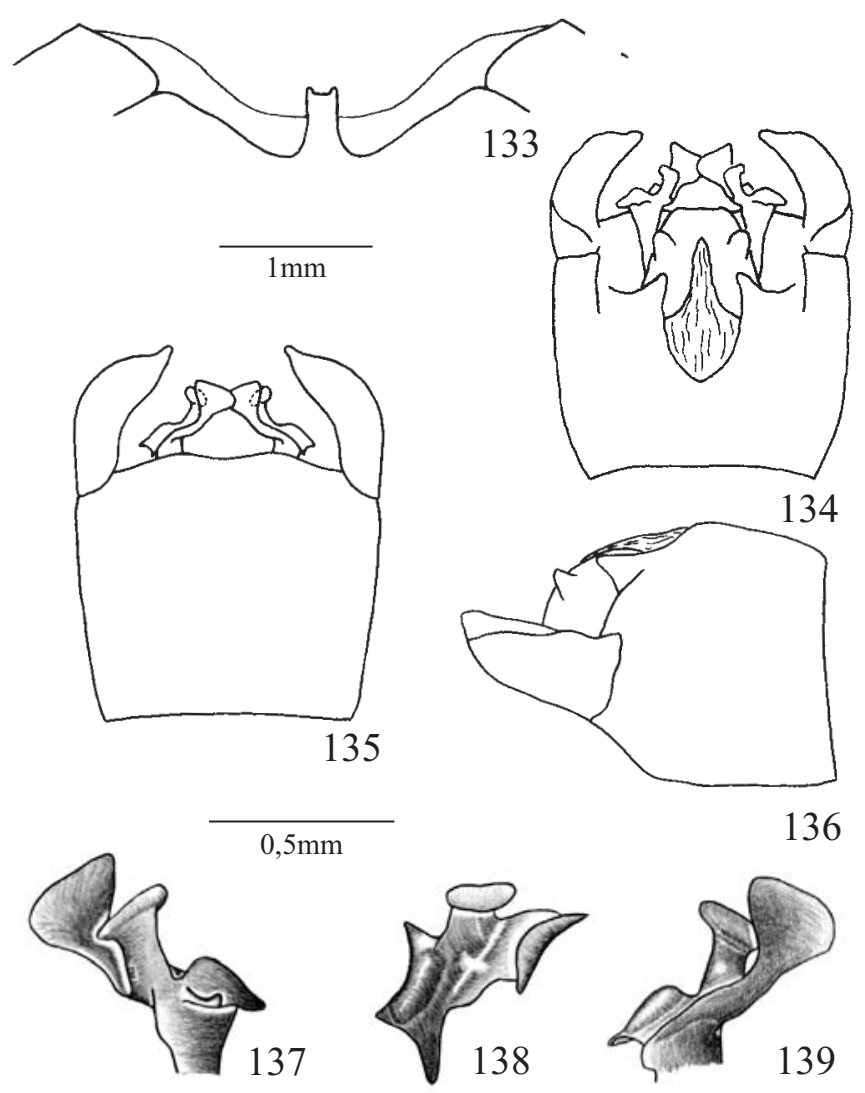

Figs. 133-139. Antiteuchus ledeburi sp. nov. 133, Processo mediano do tergito VII; 134-136, Pigóforo em vistas dorsal, ventral e lateral, respectivamente; 137-139, Parâmero em vistas dorsal, posterior e ventral, respectivamente.

mancha escura no 1/4 apical. Face ventral levemente convexa.

Cabeça do parâmero (figs. 88-90) composta por 4 lobos: dorsal estreito, inteiro, delgado, projetado posteriormente, levemente curvado ventralmente e expandido no ápice; carena dorsal muito alta, cruzando o lobo dorsal e terminando sobre o ângulo interno da área expandida. Lobo lateral interno triangular, delgado e dirigido póstero-lateralmente. Lobo lateral externo estreito, triangular, delgado e curvado láteroanteriormente. Lobo ventral arredondado, levemente côncavo, torcido, estando quase perpendicular aos outros lobos; sua margem posterior apresenta-se levemente rebatida lateralmente e projeta-se pouco sobre o corpo do parâmero, sob a forma de uma pequena carena negra.

Segmento X com tubérculos digitiformes, dirigidos posteriormente e implantados obliquamente sobre o segmento X (fig. 85). Margem lateral expandida formando uma borda que inicia na base do tubo e prolonga-se até a base dos tubérculos. Face posterior plana, perpendicular ao plano frontal do pigóforo; carenas laterais bem desenvolvidas e paralelas; crista mediana percorrendo toda face. Área membranosa dorsal terminando entre os tubérculos.

Holótipo macho: BRASIL, Amapá: Mazagão, 21-XI-1983, I. S. Gorayeb e equipe col., com rede (MPEG). Parátipos: BRASIL, Amapá: 
Macapá, Paroval, 14-XII-1982, W. França, 1 fêmea (MPEG); Macapá, 29-II-2004, R. Adaime, sobre gramínea, 1 fêmea (UFRG); Macapá, 12II-2004, R. Adaime, sobre gramínea, 1 macho e 1 fêmea (UFRG); Macapá, 21-II-2004, R. Adaime, sobre Castanholeira, 1 fêmea (UFRG); Macapá, 16-V-2004, R. Adaime, sobre Castanholeira, 1 macho (UFRG); Porto Santana, 2-IV-1961, Dr. Egler, 1 macho (MPEG).

Distribuição: Brasil, Amapá: Macapá, Porto Santana, Mazagão.

Comentários: Os exemplares examinados pertencem à coleção do MPEG e UFRG. Esta espécie pode ser identificada pelo lobo dorsal do parâmero estreito, projetado posteriormente, levemente curvado ventralmente e expandido no ápice; pela carena dorsal muito alta, cruzando o lobo dorsal e terminando sobre o ângulo interno da área expandida.

Antiteuchus confinium Ruckes, 1964

(Figs. 91-97, 303)

Antiteuchus (Antiteuchus) confinium Ruckes, 1964: 85 (chave), 9495, figs. 63-65; Rolston, 1993: 110 (chave), 122, figs. 49-51.

Medidas (n=3): comprimento total- 11,0-11,8; largura total6,7-7,4.

Segmentos antenais I e II amarelos com manchas escuras. Segmentos III e IV negros, sendo que o IV possui um anel amarelo na base. Segmento V amarelo e escurecido na metade distal. Segmentos em ordem crescente de comprimento: I; II; III; IV; V.

Urotergito VII sem impressões laterais a projeção mediana. Processo mediano do urotergito VII bem desenvolvido, parte livre alargada na base, retangular no restante, curta, estreita, convexa transversalmente, reta e dirigida ventralmente; ápice dobrado ventralmente, margem posterior inteira. Margem da membrana quase coincidindo com a margem posterior do processo mediano (fig. 91).

Pigóforo amarelo-escuro e sem um tufo de pêlos longos na lateral, junto ao ângulo póstero-lateral do pigóforo. Processo látero-dorsal desenvolvido, caracterizado por uma elevação intumescida da margem dorsal que não se funde ao ângulo póstero-lateral do pigóforo (fig. 94). Projeções do bordo dorsal, laterais ao segmento $\mathrm{X}$, arredondadas e não projetadas em direção aos tubérculos deste (fig. 92). Bordo ventral trapezoidal, dobrado posteriormente nos 1/3 laterais e plano no 1/3 médio; margem superior levemente côncava e mais estreita que a extremidade do segmento X (fig. 93). Superfície ventral do pigóforo, logo abaixo do bordo ventral, apresentando uma área mediana côncava recoberta por pêlos esparsos, com uma protuberância ampla e baixa no centro e algumas manchas grandes castanho-escuras. Ângulo póstero-lateral do pigóforo triangular, em torno de 2 vezes mais longo que largo, em vista lateral, e não obstruindo a visão da taça genital; ápice triangular associado ao final da carena. Face interna de cada ângulo póstero-lateral do pigóforo levemente côncava na metade basal e plana no restante, margem ventral interna com uma carena negra desenvolvida e com um dente achatado, dirigido lateralmente, negro e localizado junto ao ápice; coloração castanha. Face dorsal convexa com exceção de uma área
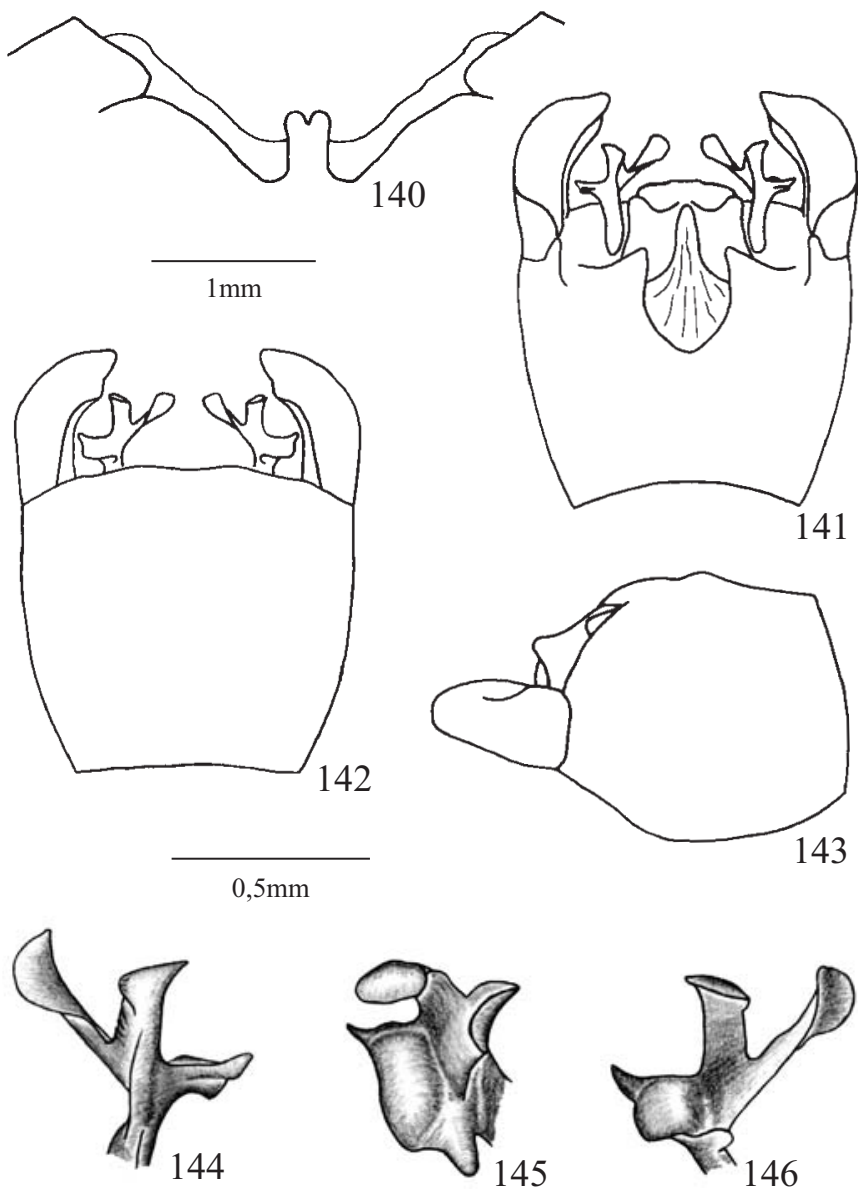

Figs. 140-146. Antiteuchus beckerae sp. nov. 140, Processo mediano do tergito VII; 141-143, Pigóforo em vistas dorsal, ventral e lateral, respectivamente; 144-146, Parâmero em vistas dorsal, posterior e ventral, respectivamente.

escavada localizada adiante de uma prega em declive, observando-a da margem externa para interna; ápice e margens interna e externa castanho-escuras. Face ventral levemente convexa e castanha.

Cabeça do parâmero (figs. 95-97) composta por 4 lobos: Dorsal convexo transversalmente, estreito, longo, afilado em direção ao ápice e levemente inclinado posteriormente, margem lateral interna levemente curvada em direção à lateral externa; carena dorsal alta e terminando no ápice do processo. Lobo lateral interno longo, reto, largo, delgado, sub-retangular, ápice arredondado e dirigido póstero-ventralmente. Lobo lateral externo pouco desenvolvido, triangular e levemente curvado lateralmente. Lobo ventral espiniforme, achatado, ápice truncado e dirigido ventralmente.

Tubérculos do segmento X pequenos, achatados, dirigidos dorsalmente e implantados obliquamente sobre o segmento $\mathrm{X}$ (fig. 92). Face posterior plana, muito inclinada, quase perpendicular ao plano frontal do pigóforo; carenas laterais pouco desenvolvidas; crista mediana percorrendo toda face. Área membranosa dorsal terminando antes da base dos tubérculos. 
Holótipo macho. "Peru-Brazil frontier; February 14, 1928; Harvey Bassler coll." (AMNH). Examinado.

Distribuição: Equador, Napo: Coca. PERÚ, Loreto: Fronteira entre Brasil-Perú.

Comentários: Os exemplares analisados pertencem às coleções do AMNH, BMNH e MCNZ. Esta espécie pode ser reconhecida pelo processo mediano do urotergito VII retangular com o ápice dobrado ventralmente; pelo ângulo póstero-lateral do pigóforo triangular em vista lateral; pelo lobo dorsal do parâmero estreito, afilado em direção ao ápice e levemente inclinado posteriormente; e pelos tubérculos do segmento X pequenos e dirigidos dorsalmente. A. confinium e $A$. mimeticus são semelhantes quanto ao urotergito VII liso e sem impressões; as projeções do bordo dorsal, laterais ao segmento X, arredondadas e não projetadas em direção aos tubérculos deste; o lobo lateral externo do parâmero pouco desenvolvido, triangular e levemente curvado lateralmente. Esta espécie tem em comum com A. doesburgi o processo látero-dorsal do pigóforo desenvolvido.

\section{Antiteuchus mimeticus Ruckes, 1964}

(Figs. 98-104, 303)

Antiteuchus (Antiteuchus) mimeticus Ruckes, 1964: 85 (chave), 100101, figs. 75-77; Rolston, 1993: 110 (chave), 128, figs. 63-65.

Medidas $(n=2)$ : comprimento total- 10,8-11,3; largura total$6,7-7,2$

Segmentos antenais I e II amarelos com manchas escuras. Segmentos III e IV negros, sendo que o IV possui um anel claro na base. Segmento V amarelo e escurecido na metade distal. Segmentos em ordem crescente de comprimento: I e II subiguais; III; IV; V.

Urotergito VII sem impressões laterais a projeção mediana. Processo mediano do urotergito VII bem desenvolvido, parte livre curta, larga, levemente convexa transversalmente, reta e dirigida ventralmente; ápice expandido, margem posterior inteira. Margem posterior do processo mediano praticamente coincidindo com a margem da membrana (fig. 98).

Pigóforo amarelo-escuro e sem um tufo de pêlos longos na lateral, junto ao ângulo póstero-lateral do pigóforo. Processo látero-dorsal pouco desenvolvido, caracterizado pela ausência de uma elevação na parede do pigóforo em vista lateral, e não atingindo a base do ângulo póstero-lateral do pigóforo (fig. 101). Projeções do bordo dorsal, laterais ao segmento $X$, arredondadas e não projetadas em direção aos tubérculos deste (fig. 99). Bordo ventral trapezoidal, largo e plano; margem superior tão larga quanto a extremidade do segmento X (fig. 100). Superfície ventral do pigóforo, logo abaixo do bordo ventral, apresentando uma área mediana côncava recoberta por pêlos esparsos, com uma protuberância ampla e baixa no centro e algumas manchas grandes castanho-escuras. Ângulo póstero-lateral do pigóforo ogival, em vista lateral, cerca de 2 vezes mais longo que largo, em vista lateral, e não obstruindo a visão da taça genital, em vista posterior. Face interna de cada ângulo póstero-lateral levemente côncava, margem ventral
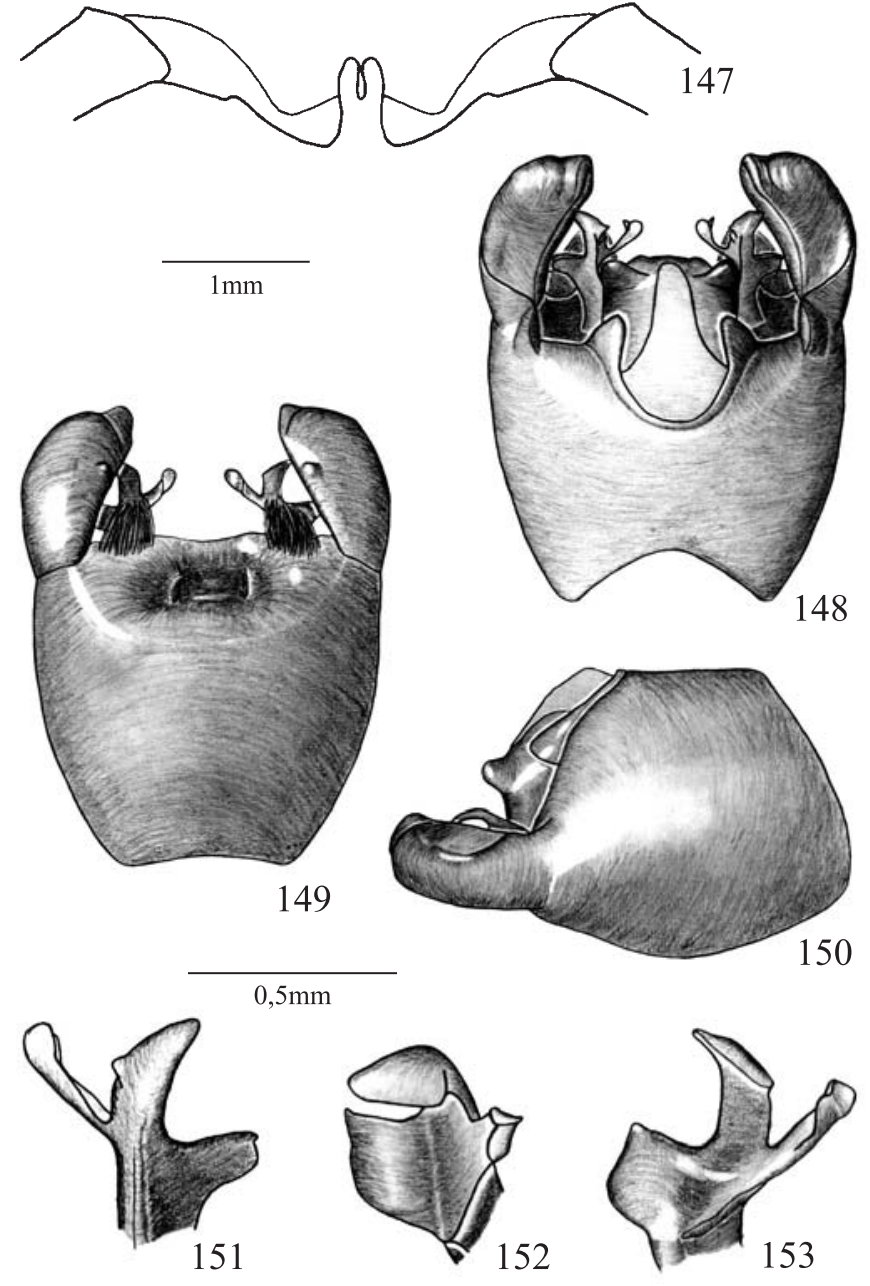

Figs. 147-153. Antiteuchus peruensis. 147, Processo mediano do tergito VII; 148-150, Pigóforo em vistas dorsal, ventral e lateral, respectivamente; 151-153, Parâmero em vistas dorsal, posterior e ventral, respectivamente.

interna com uma carena negra desenvolvida, com exceção de uma área próxima ao ápice, e com um dente achatado, dirigido lateralmente, negro e localizado junto ao ápice. Face dorsal convexa com exceção de uma grande área plana localizada adiante de uma prega em declive, observando-a da margem externa para interna; ápice com uma grande mancha negra ou castanho-escura.

Cabeça do parâmero (figs. 102-103) composta por 4 lobos: Dorsal grande, convexo transversalmente, longo e suavemente curvado posteriormente, margem lateral interna curvada para lateral externa; carena dorsal inconspícua. Lobo lateral interno digitiforme, longo, estreito, levemente achatado e dirigido póstero-lateralmente. Lobo lateral externo pouco desenvolvido, triangular, levemente achatado, com uma pequena área intumescida na base e curvado ânterolateralmente. Lobo ventral sub-retangular, achatado lateralmente e dirigido ventralmente.

Tubérculos do segmento $\mathrm{X}$ achatados, dirigidos dorso- 
posteriormente e implantados obliquamente sobre o segmento $\mathrm{X}$ (figs. 99). Face posterior plana, muito inclinada quase perpendicular ao plano frontal do pigóforo; carenas laterais pouco desenvolvidas; crista mediana percorrendo toda face. Área membranosa dorsal terminando entre os tubérculos.

Holótipo macho. "Tingo Maria, Peru, XI-1949, H. A. Allard" (NMNH). Examinado.

Distribuição: Brasil, Rondônia. Perú, Huánuco: Tingo Maria.

Comentários: Espécie conhecida apenas pelo holótipo e por um exemplar da UFRG. Esta espécie pode ser caracterizada pelo processo látero-dorsal do pigóforo pouco desenvolvido; pela margem ventral interna do ângulo póstero-lateral com uma carena negra percorrendo quase toda sua extensão; pelo lobo dorsal do parâmero suavemente curvado posteriormente e apresentando as carenas da margem lateral muito desenvolvidas, quando comparado às demais espécies do grupo; pelo lobo ventral do parâmero sub-retangular, achatado lateralmente e dirigido ventralmente.

\section{Antiteuchus doesburgi sp. nov.}

(Figs. 105-111, 303)

Etimologia: Homenagem ao Dr. Pieter H. van Doesburg que fez grandes contribuições ao atual conhecimento de alguns grupos de Heteroptera.

Medidas ( $\mathrm{n}=10)$ : comprimento total- 10,2-11,2; largura total$6,4-7,1$.

Coloração geral castanho-escura na face dorsal e castanho nas pernas, conexivo e face ventral do abdome. Ventralmente o tórax apresenta coloração castanha com pontuação castanhoescura e sem manchas negras. Calos da meso e metapleura castanhos. Artículos antenais I, II e III castanhos com manchas castanho-escuras. Artículos IV e V castanho-escuros com anel basal amarelo. Segmentos em ordem crescente de comprimento: II; I; III; IV; V.

Urotergito VII com um par de impressões largas e pouco profundas laterais à projeção mediana. Processo mediano do urotergito VII bem desenvolvido, parte livre longa, estreita, convexa transversalmente e curvada ventralmente; ápice expandido, margem posterior levemente sulcada. Margem posterior do processo mediano ultrapassando muito a margem da membrana (fig. 105).

Pigóforo castanho-claro e sem um tufo de pêlos longos na lateral, junto ao ângulo póstero-lateral do pigóforo. Processo látero-dorsal desenvolvido, caracterizado por uma convexidade na margem dorsal, não atingindo à base do ângulo póstero-lateral do pigóforo (fig. 108). Projeções do bordo dorsal, laterais ao segmento $\mathrm{X}$, projetadas em direção aos tubérculos deste (fig. 106). Bordo ventral trapezoidal, estreito e sinuoso; margens dos 1/3 laterais levemente dobrados posteriormente, margem do $1 / 3$ mediano biconvexa e tão larga quanto a extremidade do segmento $X$ (fig. 107). Superfície ventral do pigóforo, logo abaixo do bordo ventral,

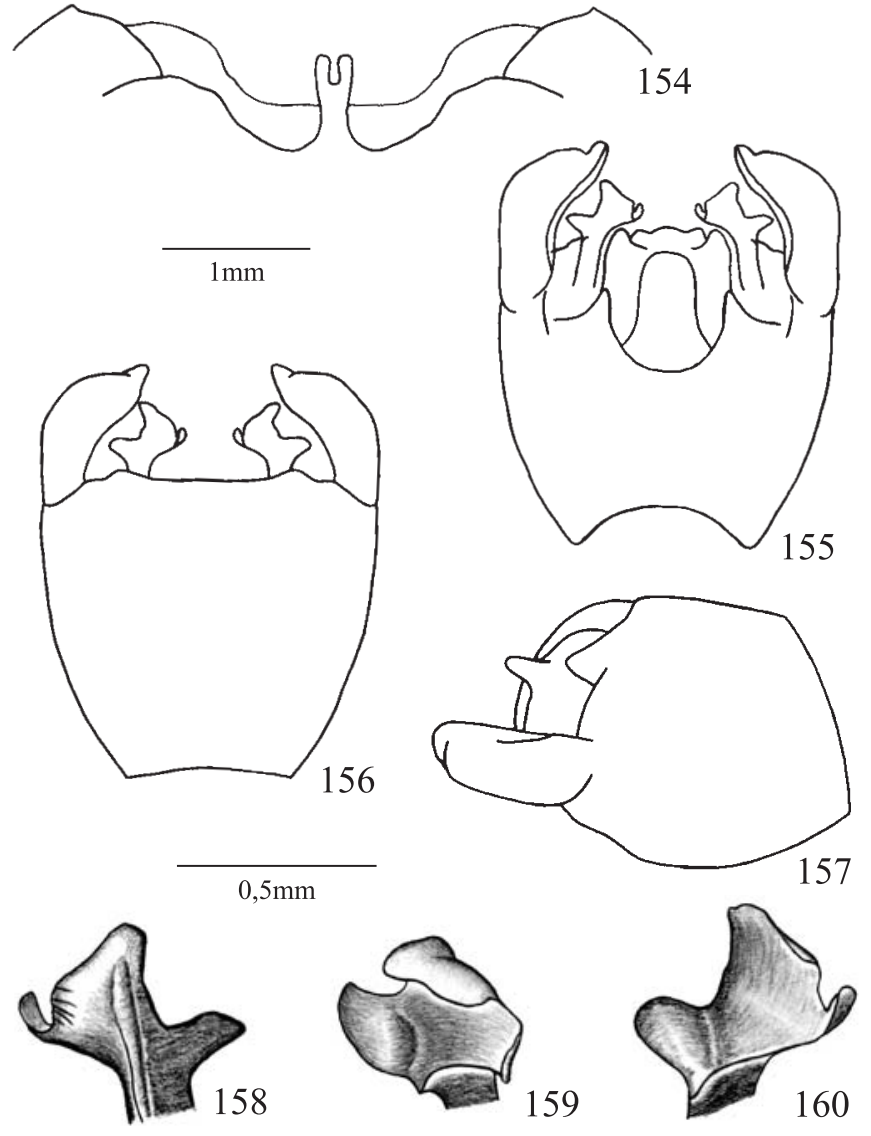

Figs. 154-160. Antiteuchus rolstoni. 154, Processo mediano do tergito VII; 155-157, Pigóforo em vistas dorsal, ventral e lateral, respectivamente; 158-160, Parâmero em vistas dorsal, posterior e ventral, respectivamente.

apresentando uma área mediana côncava recoberta por pêlos esparsos e com uma protuberância pequena e baixa no centro. Ângulo póstero-lateral do pigóforo, em vista lateral, subretangular e cerca de 3 vezes mais longo que largo; achatado lateralmente, bastante curvados internamente, mas não obstruindo a visão da taça genital, em vista posterior. Face interna plana e castanho escura, margem ventral interna com uma carena negra, desenvolvida, restrita à metade superior do ângulo póstero-lateral. Associado a esta carena, ocorre um dente negro, achatado, dirigido ântero-lateralmente e localizado junto ao ápice. Face dorsal estreita, castanho-clara e plana, com exceção da base, convexa, e de um sulco profundo e curto junto à prega em declive, observando-a da margem externa para interna. Face ventral plana e castanha, margem castanhoescura.

Cabeça do parâmero (figs. 109-111) composta por 3 lobos e levemente girada no sentido horário. Lobo dorsal amplo, delgado, curvado ventralmente e expandido no ápice; carena dorsal baixa terminando sobre a área expandida onde curva-se lateralmente atingindo a margem externa do lobo. Lobo lateral interno ausente ou reduzido a uma pequena saliência da parede entre os lobos dorsal e ventral. Lobo lateral externo bem 
desenvolvido, lingüiforme, delgado e curvado anteriormente. Lobo ventral afilado, longo, levemente achatado e dirigido para base do ângulo póstero-lateral do pigóforo.

Tubérculos do segmento $\mathrm{X}$ achatados, dirigidos dorsoposteriormente e implantados obliquamente sobre o segmento $\mathrm{X}$ (fig. 106). Face posterior plana, muito inclinada, quase perpendicular ao plano frontal do pigóforo; carenas laterais pouco desenvolvidas; crista mediana percorrendo toda face. Área membranosa dorsal terminando antes dos tubérculos.

Holótipo macho: SURINAME, Nickerie: Kabelstation, 22-VII1963, P. H. van Doesburg (RMNH). Parátipos: SURINAME, Brokopondo: Zanderij, 20-IV-1939, Geÿskes, op Mauritius Palm richten, 1 macho (UFRG) e 2 fêmeas (MCNZ); Nickerie: Kabelstation, 22-VII-1963, P. H. van Doesburg, 4 fêmeas (RMNH) e 1 fêmea (UFRG) BRASIL, Amazonas: Manaus, Tarumã, 9-IV-1988, Ribeiro, J. col., 1 macho (INPA)

Distribuição: SURINAME, Brokopondo: Zanderij; Nickerie: Kabelstation. BRASIL, Amazonas: Manaus.

Comentários: Os exemplares examinados pertencem às coleções do UFRG, INPA, MCZN e RMNH. Esta espécie pode ser reconhecida pelo processo mediano do urotergito VII com ápice expandido e margem posterior levemente sulcada; pelas projeções do bordo dorsal, laterais ao segmento X, projetadas em direção aos tubérculos deste; pelo ângulo póstero-lateral do pigóforo sub-retangular, em vista lateral, e achatado lateralmente; pela margem ventral interna deste ângulo com uma carena restrita à metade apical; pelo lobo dorsal do parâmero curvado ventralmente e expandido no ápice; pelo lobo lateral interno inconspícuo.

\section{Antiteuchus bartletti Ruckes, 1964} (Figs. 112-118, 304)

Antiteuchus (Antiteuchus) bartletti Ruckes, 1964: 85 (chave), 97-98, figs. 72-74; Rolston, 1993: 109 (chave), 115, figs. 23-24

Medidas (n=2): comprimento total- 10,3-11,2; largura total$6,6-6,7$.

Segmento antenal I amarelo com manchas escuras. Segmentos antenais II-V desconhecidos.

Margem do urotergito VII com um par de impressões largas e profundas, uma de cada lado da projeção mediana. Membrana do urotergito VII reduzida junto ao processo mediano. Processo mediano do urotergito VII reduzido a uma convexidade da margem posterior. Ápice do processo mediano quase coincidindo com a margem da membrana (fig. 112).

Pigóforo mutilado em ambos os exemplares conhecidos. Devido a seu estado não foi possível constatar a presença ou ausência de um tufo de pêlos na lateral, junto ao ângulo póstero-lateral do pigóforo. Processo látero-dorsal desenvolvido formado por uma pequena elevação da parede do pigóforo, não atingindo a base do ângulo póstero-lateral do pigóforo (fig. 115). Projeções do bordo dorsal, laterais ao segmento $\mathrm{X}$, não projetadas em direção aos tubérculos deste (fig. 113). Não foi possível estabelecer a relação entre a largura e profundidade da escavação do bordo dorsal, mas parece ser

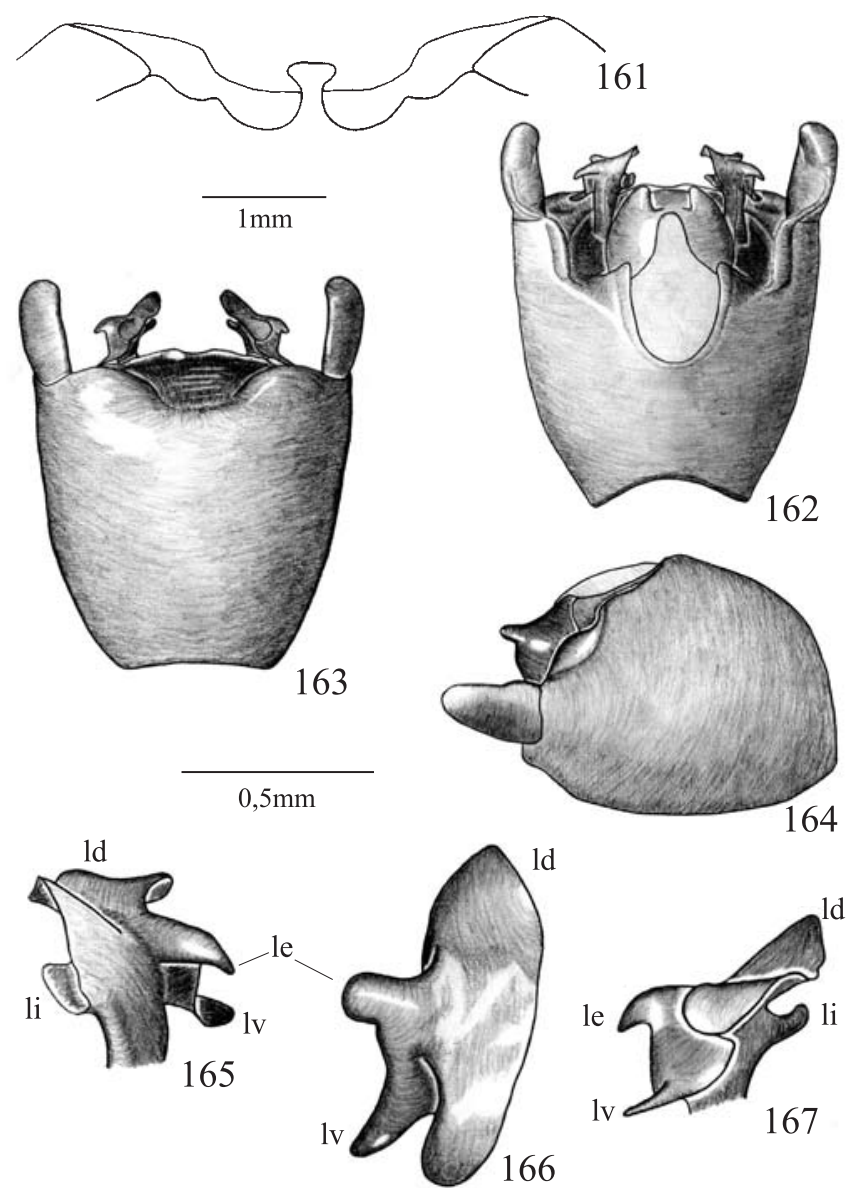

Figs. 161-167. Antiteuchus tesselatus. 161, Processo mediano do tergito VII; 162-164, Pigóforo em vistas dorsal, ventral e lateral, respectivamente; 165-167, Parâmero em vistas dorsal, posterior e ventral, respectivamente. (ld- lobo dorsal; le- lobo lateral externo; lilobo lateral interno; lv- lobo ventral).

tão larga quanto profunda. Bordo ventral trapezoidal, dobrado posteriormente nos 1/3 laterais e plano no 1/3 médio; margem superior levemente côncava e mais estreita que a extremidade do segmento X (fig. 114). Superfície ventral do pigóforo, logo abaixo do bordo ventral, apresentando uma área mediana côncava, profunda, margeada por uma faixa pontuada castanha, recoberta por pêlos esparsos e sem uma área mediana elevada. Ângulo póstero-lateral do pigóforo sub-retangular, em vista lateral, cerca de 2 vezes mais longo que largo, em vista lateral, e não obstruindo a visão da taça genital, em vista posterior; ápice cônico. Face interna de cada ângulo póstero-lateral do pigóforo convexa na metade basal e plana no restante, sem um tubérculo na margem ventral interna. Face dorsal convexa com exceção de uma área escavada acima da prega em declive, observando-a da margem externa para interna, e outra na linha mediana longitudinal que estende-se até próximo ao ápice; margem interna e ápice castanho-escuros.

Cabeça do parâmero (figs. 116-118) composta por 3 lobos aparentes. Dorsal curto, largo, inteiro, curvado posteriormente 
e sem expansão no ápice; carena dorsal inconspícua. Lobo lateral interno inconspícuo, talvez reduzido a uma pequena área dobrada quase ventral. Lobo lateral externo triangular, amplo, delgado e curvado látero-anteriormente. Lobo ventral longo, afilado e dobrado ântero-lateralmente.

Tubérculos do segmento $\mathrm{X}$ achatados, dirigidos posteriormente e implantados obliquamente sobre o segmento $\mathrm{X}$ (fig. 113). As bases dos tubérculos projetam-se obliquamente, em direção à linha mediana longitudinal, onde fundem-se formando uma região intumescida que prolongase até a metade da face posterior. Face posterior levemente convexa, muito inclinada, quase perpendicular ao plano frontal do pigóforo; carenas laterais pouco desenvolvidas; crista mediana substituída por uma pequena e estreita área intumescida. Área membranosa dorsal terminando antes da linha dos tubérculos.

Holótipo macho. "B. Guiana, Bartlett coll., B. M. 1943-60" (BMNH). Examinado.

Distribuição: Guiana.

Comentários: Os únicos dois exemplares conhecidos estão mutilados, sendo o parátipo o que está em piores condições. O tipo não possui o hemiélitro direito e apenas o primeiro artículo antenal esquerdo, seu pigóforo está amassado e bastante quebrado ventralmente, o parâmero esquerdo está montado em triângulo de papel. O parátipo possui apenas o primeiro artículo antenal, em ambas as antenas; seu pigóforo está totalmente mutilado sendo possível reconhecer o segmento $\mathrm{X}$ e o ângulo póstero-lateral do pigóforo direito. Rolston (1993) se equivocou ao afirmar que, segundo Ruckes (1964), o segundo segmento antenal era 4/10 do terceiro. Ruckes apenas mencionou que as antenas estavam mutiladas. Os exemplares analisados pertencem ao BMNH e AMNH. Esta espécie pode ser reconhecida pelo processo mediano do urotergito VII reduzido a uma convexidade da margem posterior; pelo ângulo póstero-lateral do pigóforo não obstruindo a visão da taça genital em vista posterior; pelo lobo lateral interno do parâmero inconspícuo, talvez reduzido a uma pequena área dobrada quase ventral; pelo lobo ventral longo e dobrado ânterolateralmente. Esta espécie e $A$. guianensis têm em comum a membrana do urotergito VII estreitando-se junto ao processo mediano e o ápice de cada ângulo póstero-lateral do pigóforo cônico. A. bartletti tem em comum com A. guianensis e A. cuspidatus as projeções do bordo dorsal, laterais ao segmento $\mathrm{X}$, não projetadas em direção aos tubérculos deste; as bases dos tubérculos do segmento $\mathrm{X}$ projetados obliquamente em direção à linha mediana longitudinal, conferindo uma forma triangular ao ápice do segmento. A. bartletti e A. cuspidatus possuem a forma do processo látero-dorsal semelhante.

Antiteuchus guianensis Ruckes, 1964

(Figs. 119-125, 304)

Antiteuchus (Antiteuchus) guianensis Ruckes, 1964: 85 (chave), 9596, figs. 66-68; Rolston, 1993: 110 (chave), 127, figs. 54-56.

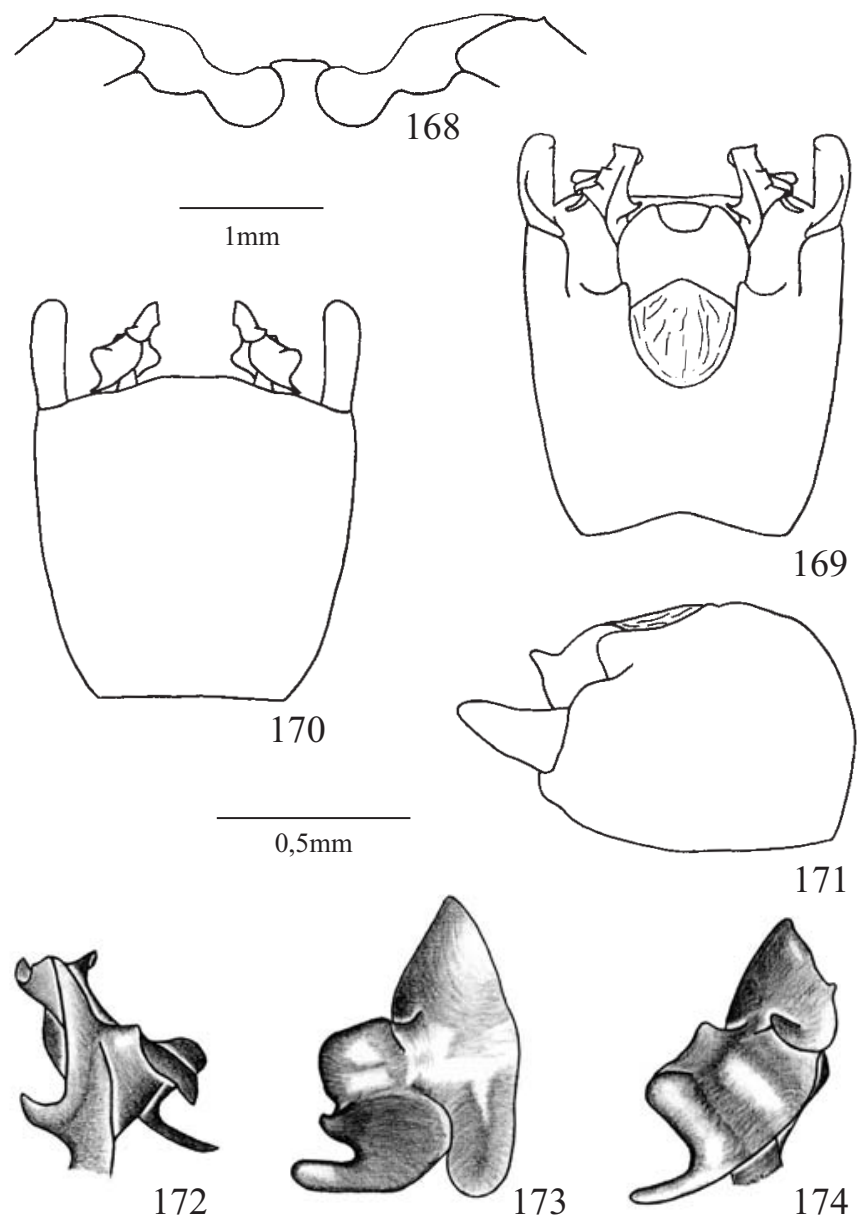

Figs. 168-174. Antiteuchus marini sp. nov. 168, Processo mediano do tergito VII; 169-171, Pigóforo em vistas dorsal, ventral e lateral, respectivamente; 172-174, Parâmero em vistas dorsal, posterior e ventral, respectivamente.

Medidas ( $\mathrm{n}=5$ ): comprimento total- 11,2-11,6; largura total7,2-7,9.

Segmentos antenais I e II amarelos com manchas escuras. Segmentos III e IV negros com a base amarela. Segmento V amarelo com a metade superior mais escura que a inferior. Segmentos em ordem crescente de comprimento: I; II; III; IV e $\mathrm{V}$ subiguais.

Margem do urotergito VII com um par de projeções subtriangulares no ápice e um par de impressões largas e profundas, uma de cada lado da projeção mediana. Membrana do urotergito VII reduzida junto ao processo mediano. Processo mediano do urotergito VII bem desenvolvido, parte livre pouco mais longa que larga, convexa transversalmente, reta e dirigida póstero-ventralmente; ápice expandido, margem posterior inteira. Margem posterior do processo mediano ultrapassando pouco a margem da membrana (fig. 119).

Pigóforo amarelo e com um tufo de pêlos longos na lateral, junto ao ângulo póstero-lateral do pigóforo. Processo láterodorsal muito desenvolvido, formado por uma elevação da 
parede do pigóforo achatada lateralmente, e parcialmente fundido com o $1 / 3$ basal do ângulo póstero-lateral do pigóforo (fig. 122). Projeções do bordo dorsal, laterais ao segmento X, pouco desenvolvidas e não projetadas em direção aos tubérculos deste (fig. 120). Bordo ventral estreito e plano, margem lateral com uma área convexa junto ao ângulo pósterolateral do pigóforo, margem superior biconvexa e mais estreita que a extremidade do segmento X (fig. 121). Superfície ventral do pigóforo, logo abaixo do bordo ventral, apresentando uma área mediana côncava, profunda, recoberta por pêlos esparsos e sem uma área mediana elevada. Ângulo póstero-lateral do pigóforo, em vista lateral, sub-retangular e cerca de 2 vezes mais longo que largo; em vista posterior, fortemente curvado internamente na metade posterior obstruindo a visão da taça genital; ápice cônico. Face interna de cada ângulo pósterolateral levemente convexa, de coloração castanha e sem carena, dente ou tubérculo na margem ventral interna. Face dorsal convexa com exceção de uma área escavada adiante da extremidade do processo látero-dorsal, prega dorsal ausente e $1 / 3$ apical de cor castanha.

Cabeça do parâmero (figs. 123-125) composta por 5 lobos aparentes. Dorsal curto, estreito, inteiro, delgado, e curvado posteriormente; carenas da margem lateral interna inconspícuas Devido à inclinação lateral do lobo dorsal; carena dorsal baixa e evanescente antes da base do lobo. Lobo lateral interno longo, delgado, alargando-se progressivamente em direção ao ápice e dirigido póstero-lateralmente. Lobo lateral externo triangular, delgado e levemente curvado látero-anteriormente. Região ventral com dois lobos distintos, um piramidal, pequeno, dirigido ventralmente, mais claro que os demais e margeado ou não de negro; o outro espiniforme, maior que o anterior, com a metade posterior negra e dirigido para base do ângulo póstero-lateral do pigóforo. Comparando com outras espécies do mesmo grupo e considerando a posição e forma dos lobos, concluímos que provavelmente o pequeno lobo piramidal seja uma projeção da base do lobo espiniforme maior.

Tubérculos do segmento $\mathrm{X}$ achatados, dirigidos posteriormente e implantados obliquamente sobre o segmento $\mathrm{X}$. As bases dos tubérculos projetam-se obliquamente, em direção à linha mediana longitudinal, onde fundem-se formando uma região intumescida que prolonga-se ventralmente até a metade da face posterior (fig. 120). Face posterior levemente convexa, muito inclinada, quase perpendicular ao plano frontal do pigóforo; carenas laterais pouco desenvolvidas; crista mediana substituída por uma área intumescida pequena e estreita. Área membranosa dorsal terminando junto aos tubérculos.

Holótipo macho. "Museum Paris, Guiane Franc., env. de Cayenne, Bas. Mahury F. Geay 1898" (AMNH). Examinado.

Distribuição: Guiana, Moraballi Creek - rio Essequibo. Guiana Francesa, Cayenne, Montjoly. Brasil, Amapá: Porto Platon.

Comentários: Os exemplares analisados pertencem às coleções do AMNH, BMNH, CASC, MNHN e UFRG. Esta espécie pode ser reconhecida pela presença de um par de
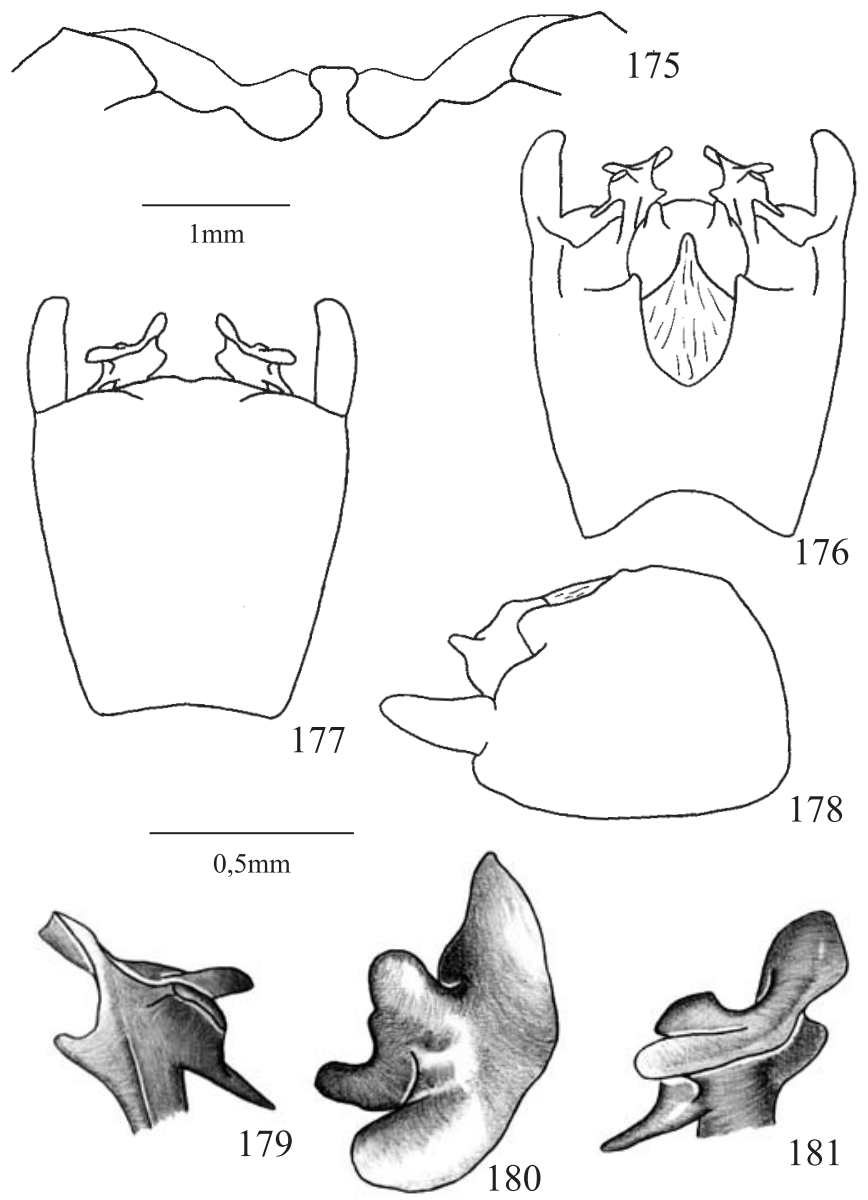

Figs. 175-181. Antiteuchus simulatus sp. nov. 175, Processo mediano do tergito VII; 176-178, Pigóforo em vistas dorsal, ventral e lateral, respectivamente; 179-181, Parâmero em vistas dorsal, posterior e ventral, respectivamente.

projeções na margem posterior do urotergito VII; pelo processo látero-dorsal muito desenvolvido e parcialmente fundido com o 1/3 basal do ângulo póstero-lateral do pigóforo; pela face dorsal de cada ângulo póstero-lateral do pigóforo com uma área escavada adiante da extremidade do processo láterodorsal; pela cabeça do parâmero composta por 5 lobos aparentes; lobo dorsal do parâmero curto e estreito. Carenas da margem lateral interna do parâmero inconspícuas, Devido à inclinação lateral do lobo dorsal. Esta espécie compartilha com A. cuspidatus, A. peruensis, A. rolstoni, A. beckerae e A. ledeburi o ângulo póstero-lateral do pigóforo fortemente curvado internamente na metade posterior obstruindo a visão da taça genital em vista posterior. Estas espécies apresentam semelhanças quanto ao lobo lateral interno do parâmero que é longo, alargado em direção ao ápice (exceto $A$. rolstoni), delgado e dirigido póstero-lateralmente.

Antiteuchus cuspidatus Ruckes, 1964

(Figs. 126-132, 304)

Antiteuchus (Antiteuchus) cuspidatus Ruckes, 1964: 85 (chave), 98-100, figs. 69-71; Rolston, 1993: 109 (chave), 116-117, figs. 28-31. 
Medidas (n=2): comprimento total- 11,3-11,6; largura total7,2-7,5.

Segmentos antenais I e II amarelos com manchas escuras. Segmento III negro. Segmento IV negro com anel basal amarelo. Segmento V amarelo na metade basal e ápice sendo o restante negro. Segmentos em ordem crescente de comprimento: II; I; III; IV e V subiguais.

Margem do urotergito VII com um par de impressões largas e profundas, uma de cada lado da projeção mediana. Processo mediano do urotergito VII bem desenvolvido, parte livre longa, estreita, plana e curvada ventralmente; ápice expandido, margem posterior levemente sulcada. Margem posterior do processo mediano ultrapassando pouco a margem da membrana (fig. 126).

Pigóforo amarelo-escuro e com um tufo de pêlos longos na lateral, junto ao ângulo póstero-lateral do pigóforo. Processo látero-dorsal desenvolvido formado por uma elevação da parede do pigóforo achatada lateralmente e não fundida com a base do ângulo póstero-lateral do pigóforo (fig. 129). Projeções do bordo dorsal, laterais ao segmento $X$, arredondados e não projetados em direção aos tubérculos deste (fig. 127). Bordo ventral trapezoidal, estreito, plano no $1 / 3$ médio e dobrado posteriormente nos $1 / 3$ laterais, margem superior reta e tão larga quanto a extremidade do segmento $\mathrm{X}$ (fig. 128). Superfície ventral do pigóforo, logo abaixo do bordo ventral, apresentando uma área mediana côncava, recoberta por pêlos esparsos e sem uma área mediana elevada. Ângulo póstero-lateral do pigóforo sub-retangular, em vista lateral, cerca de 2 vezes mais longo que largo, em vista lateral, e curvados internamente na metade posterior obstruindo a visão da taça genital, em vista posterior; ápice com um grande processo bicúspide projetado internamente. Face interna de cada ângulo póstero-lateral do pigóforo plana e com a metade superior ocupada pelo processo bicúspide. Face dorsal convexa com exceção de uma área escavada acima da prega em declive, observando-a da margem externa para interna; margem interna e algumas manchas no ápice castanho-escuras.

Cabeça do parâmero (figs. 130-132) composta por 4 lobos aparentes. Dorsal estreito, longo, inteiro, transversalmente convexo, curvado em direção ventral e com uma pequena área expandida no ápice; carena dorsal baixa e evanescente no 1/3 basal do processo. Lobo lateral interno longo, retangular, largo, levemente alargado em direção ao ápice, suavemente curvado e dirigido póstero-lateralmente, ápice arredondado. Lobo lateral externo triangular e curvado ântero-lateralmente. Lobo ventral espiniforme, achatado, reto e dirigido ventralmente.

Tubérculos do segmento $\mathrm{X}$ achatados, dirigidos posteriormente e implantados obliquamente sobre o segmento $X$ (figs. 127). As bases dos tubérculos projetam-se obliquamente, em direção à linha mediana longitudinal, onde fundem-se com a carena mediana da face posterior. Face posterior levemente convexa, muito inclinada, quase perpendicular ao plano frontal do pigóforo; carenas laterais pouco desenvolvidas; crista mediana percorrendo toda face. Área membranosa dorsal terminando na linha dos tubérculos.

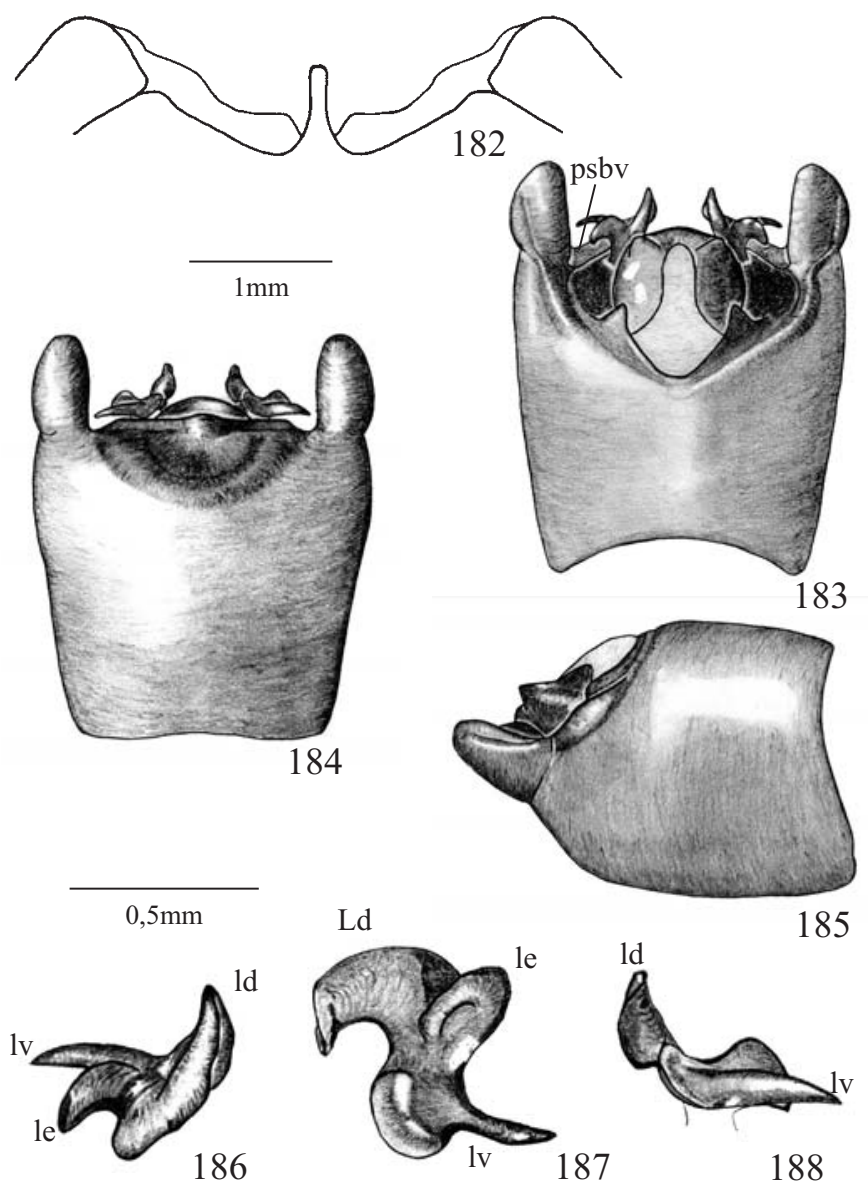

Figs. 182-188. Antiteuchus marmoratus. 182, Processo mediano do tergito VII; 183-185, Pigóforo em vistas dorsal, ventral e lateral, respectivamente; 186-188, Parâmero em vistas dorsal, posterior e ventral, respectivamente. (ld- lobo dorsal; le- lobo lateral externo; lvlobo ventral; psbv- processo superior do bordo ventral).

Holótipo macho. "Cundinamarca, Colombia" (AMNH). Examinado.

Distribuição: Panamá, Canal Zone: Pipeline road. Colômbia, Cundinamarca: Bogotá.

Comentários: Os exemplares analisados pertencem à coleção do AMNH. Esta espécie pode ser reconhecida pelo processo mediano do urotergito VII expandido no ápice e com a margem posterior levemente sulcada; pelo ápice de cada ângulo póstero-lateral do pigóforo com um grande processo bicúspide projetado internamente. Esta espécie compartilha com $A$. rolstoni, $A$. peruensis, $A$. beckerae e A. ledeburi a margem posterior do urotergito VII sulcada; a presença de uma expansão no lobo dorsal do parâmero; lobo lateral externo do parâmero triangular e curvado ântero-lateralmente.

Antiteuchus ledeburi sp. nov.

(Figs. 133-139, 304)

Etimologia. Homenagem póstuma a Ernst-Joachim Freiherr von Ledebur. 
Medidas (n=5): comprimento total- 9,8-10,8; largura total$6,1-6,7$.

Segmentos antenais I e II amarelos com manchas escuras. Segmento III negro com manchas amarelas. Segmento IV negro com o 1/3 basal amarelo. Segmento V amarelo com ápice mais escuro. Segmentos em ordem crescente de comprimento: II; I; III, IV e V subiguais.

Margem do urotergito VII com um par de impressões largas e profundas, uma de cada lado da projeção mediana. Processo mediano do urotergito VII bem desenvolvido, parte livre retangular, longa, estreita, levemente convexa transversalmente na base, achatada na metade distal e curvada ventralmente; margem posterior com sulco pouco profundo e largo, resultando em dois pequenos lobos afastados no ápice. Margem posterior do processo mediano ultrapassando pouco a margem da membrana (fig. 133).

Pigóforo amarelo-escuro e sem um tufo de pêlos longos na lateral, junto ao ângulo póstero-lateral do pigóforo. Processo látero-dorsal pouco desenvolvido, caracterizado pela ausência de uma elevação na parede do pigóforo quando se observa em vista lateral, e não projetado sobre a base do ângulo pósterolateral do pigóforo (fig. 136). Projeções do bordo dorsal, laterais ao segmento $\mathrm{X}$, avançando em direção aos tubérculos deste (fig. 134). Bordo ventral trapezoidal, estreito, plano, margem superior levemente côncava e tão larga quanto a extremidade do segmento X (fig. 135). Superfície ventral do pigóforo, logo abaixo do bordo ventral, apresentando uma área mediana côncava, profunda, recoberta por pêlos esparsos e apresentando uma área mediana elevada. Ângulo pósterolateral do pigóforo sub-retangular, em vista lateral, cerca de 2 vezes mais longo que largo, em vista lateral, e curvado internamente na metade posterior obstruindo a visão da taça genital, em vista posterior; ápice com uma aba transversal pouco achatada, estreita, triangular e projetada láterodorsalmente. Face interna de cada ângulo póstero-lateral do pigóforo com um tubérculo grande próximo ao ápice e plana, com exceção da área junto ao tubérculo que é intumescida. Face dorsal convexa com exceção de uma área escavada acima da prega em declive, observando-a da margem externa para interna, e apresentando alguns sulcos longitudinais; margem interna e algumas manchas no ápice castanho-escuras.

Cabeça do parâmero (figs. 137-139) composta por 4 lobos aparentes. Dorsal estreito, delgado, inteiro, curvado ventralmente e com uma área expandida, ovalada e plana no ápice, sendo que o corpo do lobo está fundido a região mediana desta área; carena dorsal baixa terminando na base do processo. Lobo lateral interno longo, reto, largo, delgado e dirigido póstero-lateralmente; ápice alargado e convexo. Lobo lateral externo retangular com uma projeção espiniforme no ângulo látero-dorsal e outra no ângulo látero-ventral, apresenta também uma grande área intumescida e longitudinal que ocupa a maior parte do lobo. Lobo ventral delgado, afilado, reto, dirigido ventralmente e com o ápice negro.

Tubérculos do segmento $\mathrm{X}$ achatados, dirigidos dorsoposteriormente e implantados obliquamente sobre o segmento $\mathrm{X}$ (fig. 134). Face posterior levemente convexa, muito inclinada,

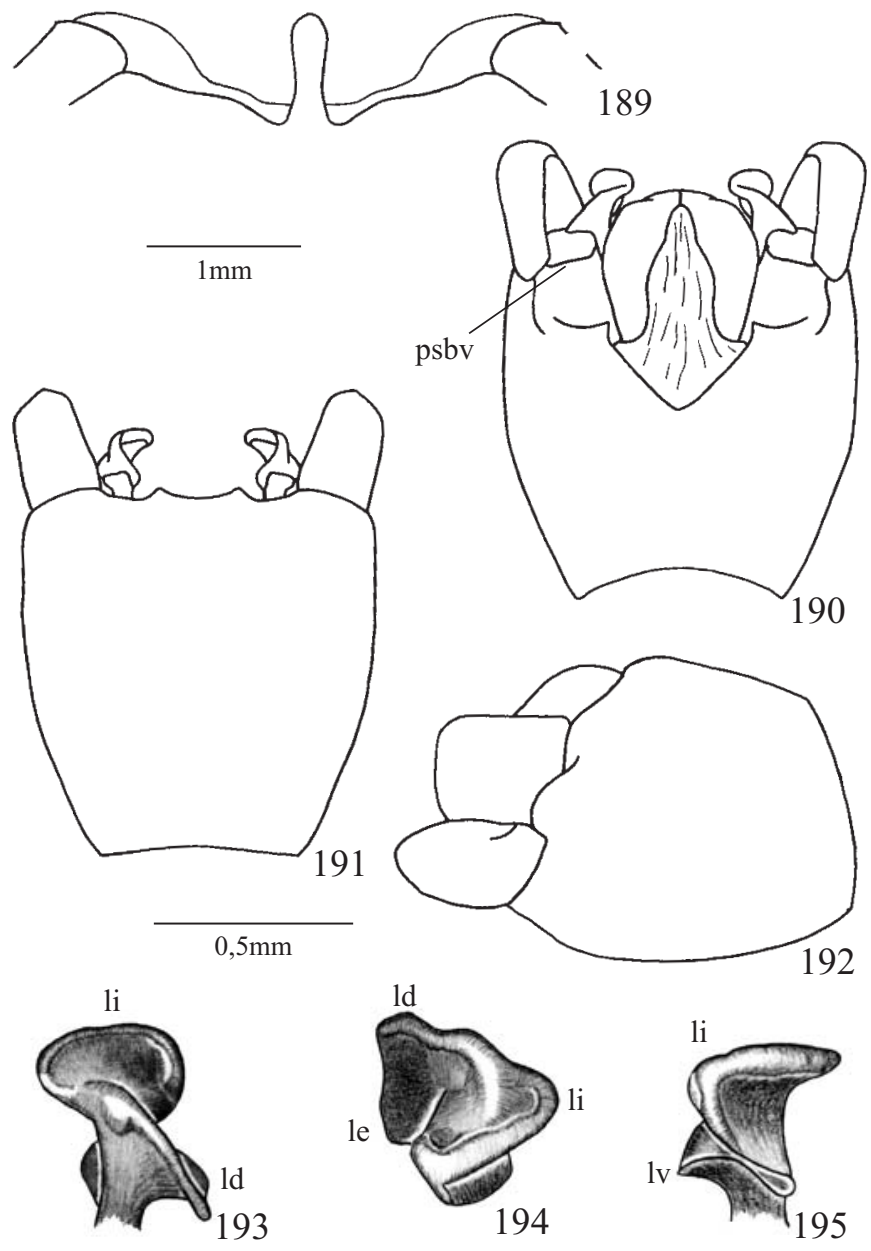

Figs. 189-195. Antiteuchus sepulcralis. 189, Processo mediano do tergito VII; 190-192, Pigóforo em vistas dorsal, ventral e lateral, respectivamente; 193-195, Parâmero em vistas dorsal, posterior e ventral, respectivamente. (ld- lobo dorsal; le- lobo lateral externo; li- lobo lateral interno; lv- lobo ventral; psbv- processo superior do bordo ventral).

quase perpendicular ao plano frontal do pigóforo; carenas laterais pouco desenvolvidas; crista mediana limitada ao 1/4 superior, nos 3/4 restantes ocorre uma área convexa. Área membranosa dorsal terminando adiante da base dos tubérculos.

Holótipo macho: BRASIL, Amazonas: Manaus, Ilha da terra nova, 12-I-1997, Fernandes, J. A. M. col. (MPEG). BRASIL, Amazonas: Manaus, Ilha da terra nova, 12-I-1997, Fernandes, J. A. M. col., 1 macho e 1 fêmea (UFRG); Pará: Belém, no 72452 e 72470 , respectivamente, 1 macho (MZSP) e 1 fêmea (MZSP).

Distribuição: BRASIL, Amazonas: Manaus; Pará: Belém.

Comentários: Os exemplares examinados pertenciam às coleções do MZSP e UFRG. Esta espécie pode ser facilmente reconhecida pela margem posterior do processo mediano do urotergito VII com dois pequenos lobos afastados um do outro; pelo ápice de cada ângulo póstero-lateral do pigóforo com uma aba triangular e projetada látero-dorsalmente; pelo lobo dorsal do parâmero com uma área expandida, ovalada e plana no ápice, estando o corpo do parâmero fundido à região 
mediana desta área; pelo lobo lateral externo do parâmero retangular com uma projeção espiniforme no ângulo láteroventral. Esta espécie tem em comum com $A$. peruensis e $A$. beckerae a presença de uma projeção espiniforme no ângulo látero-dorsal do lobo lateral externo do parâmero. Esta espécie compartilha com $A$. rolstoni, A. peruensis e A. beckerae a forma retangular do processo mediano do urotergito VII; as projeções do bordo dorsal, laterais ao segmento $\mathrm{X}$, avançando em direção aos tubérculos deste; a face interna de cada ângulo póstero-lateral do pigóforo apresentando um tubérculo junto a margem ventral; o ápice do ângulo com uma aba transversal pouco achatada; o processo látero-dorsal pouco desenvolvido; o lobo lateral externo do parâmero apresentando uma grande área intumescida e longitudinal que ocupa a maior parte do lobo.

\section{Antiteuchus beckerae sp. nov.} (Figs. 140-146, 304)

Etimologia: Homenagem a Dra. Miriam Becker que contribuiu muito para o atual estado de conhecimento de Discocephalinae.

Medidas ( $n=14)$ : comprimento total- 10,2-11,5; largura total6,9-7,4.

Segmentos antenais I e II amarelos com manchas escuras. Segmento III com a metade distal negra e basal castanhoescura. Segmento IV negro com um anel basal amarelo, ápice com um anel amarelo-escuro. Segmento V amarelo com ápice mais escuro. Segmentos em ordem crescente de comprimento: II; I; III; IV e V subiguais.

Margem do urotergito VII com um par de impressões largas e profundas, uma de cada lado da projeção mediana. Processo mediano do urotergito VII bem desenvolvido, parte livre retangular, longa, estreita, levemente convexa transversalmente na base, achatada na metade distal e curvada ventralmente; ápice não expandido, margem posterior profundamente sulcada. Margem posterior do processo mediano ultrapassando pouco a margem da membrana (fig. 140).

Pigóforo amarelo e sem um tufo de pêlos longos na lateral, junto ao ângulo póstero-lateral do pigóforo. Processo láterodorsal pouco desenvolvido, caracterizado pela ausência de uma elevação na parede do pigóforo quando se observa em vista lateral, e não projetado sobre a base do ângulo pósterolateral do pigóforo (fig. 143). Projeções do bordo dorsal, laterais ao segmento $\mathrm{X}$, avançando em direção aos tubérculos deste (fig. 141). Bordo ventral trapezoidal, estreito, plano, margem superior reta e tão larga quanto a extremidade do segmento $\mathrm{X}$ (fig. 142). Superfície ventral do pigóforo, logo abaixo do bordo ventral, apresentando uma área mediana côncava, profunda, recoberta por pêlos esparsos e apresentando uma área mediana elevada. Ângulo póstero-lateral do pigóforo sub-retangular, em vista lateral, cerca de 2 vezes mais longo que largo, em vista lateral, e curvado internamente na metade posterior obstruindo a visão da taça genital, em vista posterior; ápice com uma aba transversal pouco achatada, larga e projetada látero-dorsalmente. Face interna de cada ângulo póstero-lateral

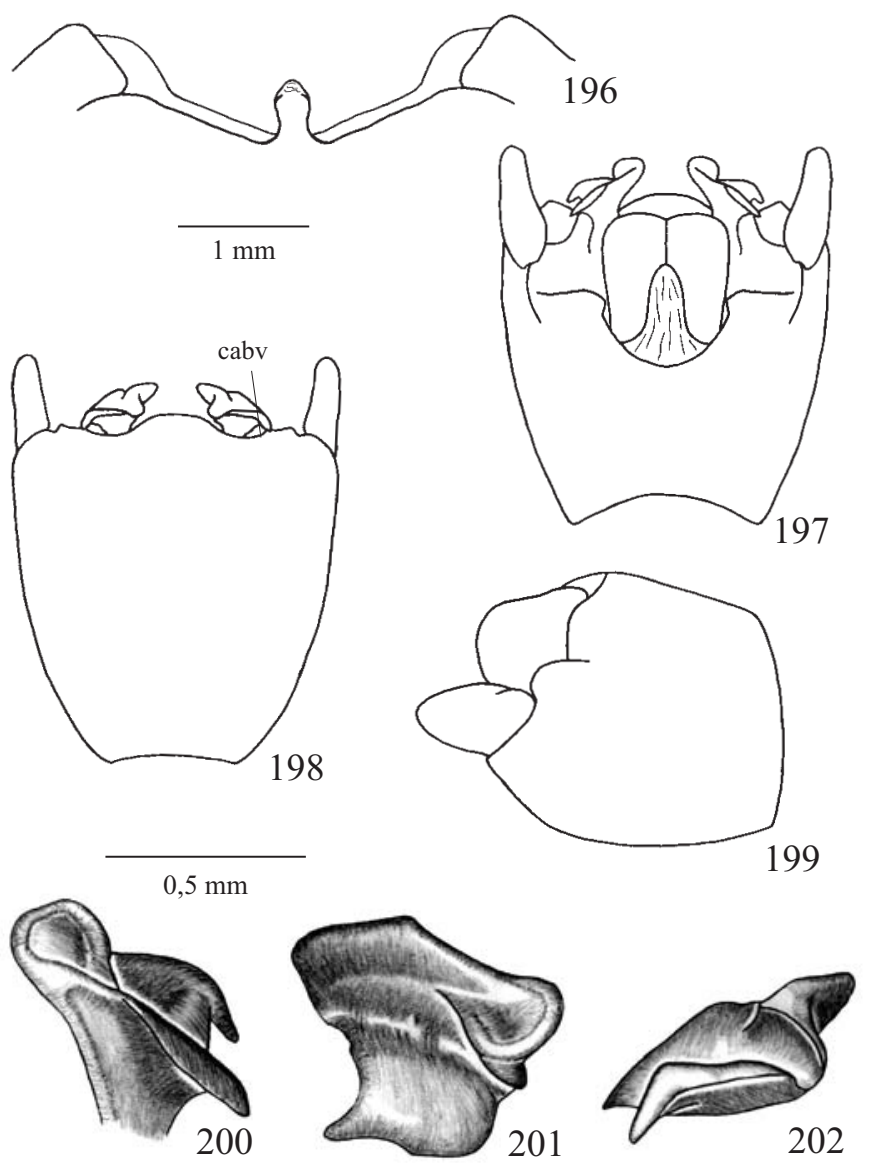

Figs. 196-202. Antiteuchus nigricans. 196, Processo mediano do tergito VII; 197-199, Pigóforo em vistas dorsal, ventral e lateral, respectivamente; 200-202, Parâmero em vistas dorsal, posterior e ventral, respectivamente. (cabv- carena do bordo ventral)

do pigóforo plana e com um grande tubérculo próximo ao ápice. Face dorsal convexa com exceção de uma área escavada acima da prega em declive, observando-a da margem externa para interna, e apresentando alguns sulcos longitudinais; margem interna e algumas manchas no ápice castanho-escuras.

Cabeça do parâmero (figs. 144-146) composta por 4 lobos aparentes. Dorsal estreito, delgado, inteiro, curvado ventralmente e com uma área expandida no ápice; carena dorsal baixa e curvada lateralmente atingindo a margem do parâmero antes da área expandida. Lobo lateral interno longo, reto, estreito, delgado e dirigido póstero-lateralmente; ápice pouco alargado e convexo. Lobo lateral externo retangular com uma projeção espiniforme no ângulo látero-dorsal e apresentando uma grande área intumescida junto a base. Lobo ventral espiniforme delgado, reto, dirigido ventralmente e com o ápice negro.

Tubérculos do segmento $\mathrm{X}$ achatados, dirigidos dorsoposteriormente e implantados obliquamente sobre o segmento X (fig. 141). Face posterior levemente convexa, muito inclinada, quase perpendicular ao plano frontal do pigóforo; carenas laterais pouco desenvolvidas; crista mediana limitada ao $1 / 4$ 
superior, nos 3/4 restantes ocorre uma área convexa. Área membranosa dorsal terminando adiante da base dos tubérculos.

Holótipo macho: BRASIL, Pará: Tomé-Açú, 1978, Mendes, A. C. col. (MPEG). Parátipos: BRASIL, Amazonas: Manaus, Rod. ManausItacoatiara Km 30, XII-1980, Mendes, A. C. col., 1 macho e 1 fêmea (INPA), 1 fêmea (MZSP), 1 fêmea (UFAM), 1 fêmea (NMNH); Manaus, Rod. Manaus-Itacoatiara Km 30, X-1979, 1 macho (MZSP); Pará: Castanhal, 1978, Mendes, A. C. col., 2 fêmeas (MPEG); Rondônia: Ouro Preto d'Oeste, 1980, A. C. Mendes col., 1 macho (UFAM), 1 macho e 1 fêmea (UFRG); Ouro Preto d'Oeste, VII-1979, 1 macho (MPEG). BOLÍVIA, Beni: Cavinas, I-1922, W. M. Mann/Mulford Biological Exploration, 1 macho (NMNH).

Distribuição: Brasil, Amazonas: Manaus; Pará: Castanhal, Tomé-Açú; Rondônia: Ouro Preto d'Oeste. BOLÍVIA, Beni: Cavinas.

Comentários: Os exemplares analisados pertenciam às coleções da UFRG e NMNH. Esta espécie pode ser diferenciada das outras pelo lobo dorsal do parâmero alongado, curvado ventralmente e com uma pequena área expandida no ápice, pouco mais larga que o lobo; lobo lateral interno com ápice pouco alargado e convexo; pela face interna de cada ângulo póstero-lateral do pigóforo com um grande tubérculo próximo ao ápice. Esta espécie compartilha com $A$. rolstoni e $A$. peruensis a presença de um sulco profundo na margem posterior do processo mediano do urotergito VII.

Antiteuchus peruensis Ruckes, 1961

(Figs. 147-153, 304)

Antiteuchus (Antiteuchus) peruensis Ruckes, 1961: 152 (não descrito) Ruckes, 1964: 84 (chave), 85-86 (descrição), figs. 3, 47-49; Rolston, 1993: 109 (chave), 112-113, figs. 9-13.

Medidas (n=3): comprimento total- 10,6-11,6; largura total6,7-7,9.

Segmentos antenais I e II amarelos com manchas escuras. Segmentos III e IV negros. Segmento V amarelo a castanhoclaro. Segmentos em ordem crescente de comprimento: II; I; III, IV e V subiguais.

Margem do urotergito VII com um par de impressões largas e profundas e um par de pequenos processos triangulares dirigidos posteriormente, ambos, um de cada lado da projeção mediana. Membrana do urotergito VII reduzida próximo ao processo mediano. Processo mediano do urotergito VII bem desenvolvido, parte livre retangular, longa, estreita, convexa transversalmente na base, achatada na metade distal e curvada ventralmente; margem posterior profundamente sulcada formando um processo bilobado no ápice (fig. 147). Margem posterior do processo mediano ultrapassando pouco a margem da membrana.

Pigóforo amarelo-escuro e sem um tufo de pêlos longos na lateral, junto ao ângulo póstero-lateral do pigóforo. Processo látero-dorsal pouco desenvolvido, caracterizado pela ausência de uma elevação na parede do pigóforo quando se observa em vista lateral, e não projetado sobre a base do ângulo póstero-lateral do pigóforo (fig. 150). Projeções do bordo dorsal, laterais ao segmento $\mathrm{X}$, avançando em direção aos

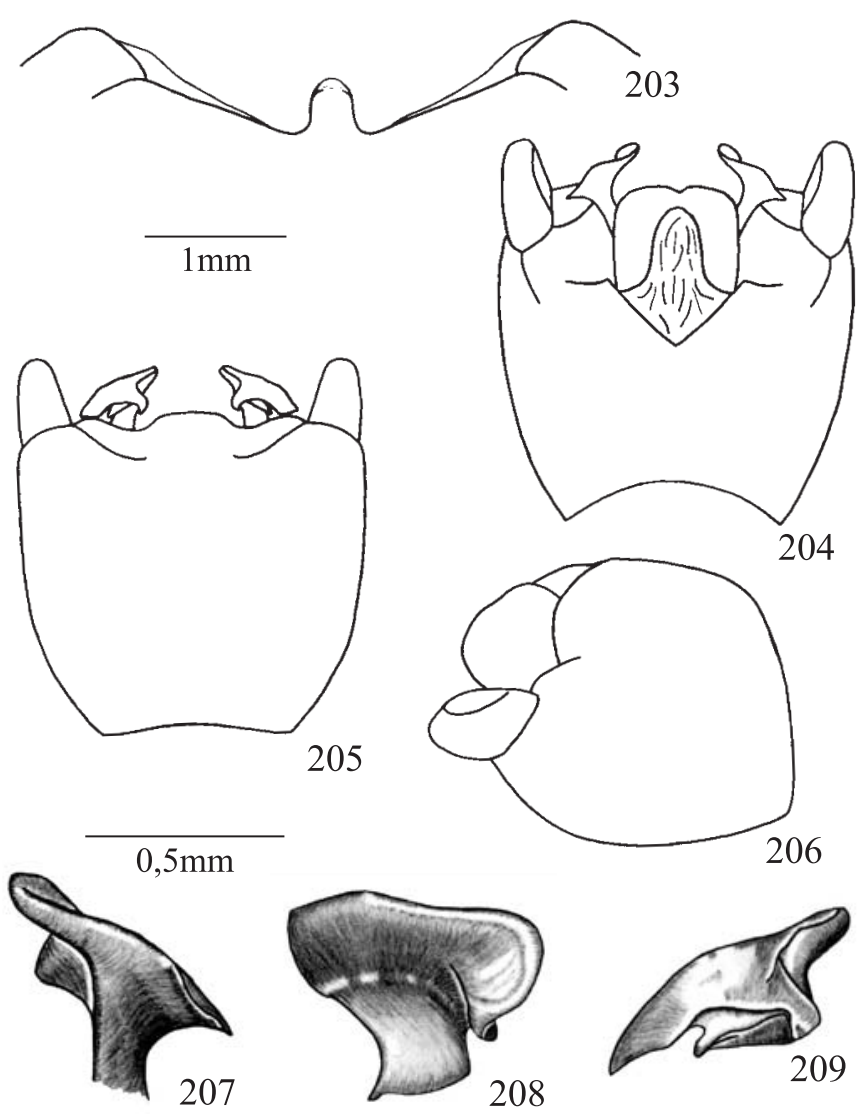

Figs. 203-209. Antiteuchus pictus. 203, Processo mediano do tergito VII; 204-206, Pigóforo em vistas dorsal, ventral e lateral, respectivamente; 207-209, Parâmero em vistas dorsal, posterior e ventral, respectivamente.

tubérculos deste (fig. 148). Bordo ventral trapezoidal, estreito, plano, margem superior côncava e tão larga quanto a extremidade do segmento $X$, em cada margem lateral se encontra uma área pouco elevada e plana com textura diferente do restante do pigóforo, recoberta por um tufo de pêlos longos (fig. 149). Superfície ventral do pigóforo, logo abaixo do bordo ventral, apresentando uma área mediana côncava, profunda, recoberta por pêlos esparsos e apresentando uma área mediana pouco elevada. Ângulo póstero-lateral do pigóforo subretangular, em vista lateral, cerca de 2 vezes mais longo que largo, em vista lateral, muito largo quando comparado ao das outras espécies e curvado internamente na metade posterior obstruindo a visão da taça genital, em vista posterior; ápice com uma aba transversal pouco achatada, larga e projetada látero-dorsalmente. Face interna de cada ângulo póstero-lateral do pigóforo levemente convexa, com um tubérculo pequeno, quase inconspícuo, no 1/3 médio. Face dorsal convexa com exceção de uma área escavada acima da prega em declive, observando-a da margem externa para interna, e apresentando alguns sulcos longitudinais; margem interna e algumas manchas no ápice castanho-escuras.

Cabeça do parâmero (figs. 151-153) composta por 3 lobos aparentes. Dorsal estreito, delgado, inteiro, curvado 
ventralmente e com uma área expandida no ápice; carena dorsal baixa e terminando sobre a área expandida. Lobo lateral interno longo, retangular, estreito, delgado e dirigido pósterolateralmente; ápice arredondado, alargado e com uma parte dorsal colocada perpendicularmente ao resto. Lobo lateral externo semi-oval com uma pequena projeção espiniforme no ângulo látero-dorsal, reto, dirigido lateralmente e apresentando uma área intumescida junto a base. Lobo ventral inconspícuo.

Tubérculos do segmento $\mathrm{X}$ achatados, dirigidos dorsoposteriormente e implantados obliquamente sobre o segmento $\mathrm{X}$ (figs. 148). Face posterior levemente convexa, muito inclinada, quase perpendicular ao plano frontal do pigóforo; carenas laterais pouco desenvolvidas; crista mediana limitada ao 1/4 superior, nos 3/4 restantes ocorre uma área convexa. Área membranosa dorsal terminando adiante da base dos tubérculos.

Holótipo macho. "Tingo Maria, Huan., Peru, Nov. 23. 1946, Alt. 2200 ft.", “J. C. Pallister coll., Frank Donor Johnson" (AMNH). Examinado.

Distribuição: Perú, Huanuco: Tingo Maria; Madre de Dios: Parque Nacional Manú; Junin: San Ramón de Pagoa.

Comentários: Os exemplares analisados pertencem às coleções do AMNH, BMNH e CASC. Esta espécie pode ser reconhecida pela forma truncada de cada elevação recoberta por pêlos da superfície ventral do pigóforo; pelo ângulo póstero-lateral do pigóforo muito largo quando comparado ao das outras espécies; pela face interna de cada ângulo pósterolateral do pigóforo levemente convexa e com um tubérculo pequeno, quase inconspícuo, no 1/3 médio; pelo lobo lateral interno do parâmero com ápice arredondado, alargado e com uma parte dorsal colocada perpendicularmente ao resto do lobo, conferindo ao ápice uma forma de "T" em vista posterior; pelo lobo ventral do parâmero inconspícuo. A. peruensis e $A$. rolstoni compartilham a área lateral da superfície ventral com 1+1 elevações recobertas por pêlos longos.

\section{Antiteuchus rolstoni Engleman, 1976}

(Figs. 154-160, 304)

Antiteuchus (Antiteuchus) rolstoni Engleman, 1976: 533-536, figs. 16; Rolston, 1993: 109 (chave), 113, figs. 19-22.

Medidas (n=6): comprimento total- 10,8-11,8; largura total6,9-7,5.

Segmentos antenais I e II amarelos com manchas escuras. Segmentos III e IV negros, sendo que o ápice do último possui um anel mais claro. Segmento V amarelo a castanho-claro. Segmentos em ordem crescente de comprimento: II; I; III; IV e $\mathrm{V}$ subiguais.

Margem do urotergito VII com um par de impressões largas e profundas e um par de dentes dirigidos posteriormente (algumas vezes quase inconspícuo), ambos laterais à projeção mediana. Processo mediano do urotergito VII bem desenvolvido, parte livre retangular, longa, estreita, convexa transversalmente na base, achatada na metade distal e curvada

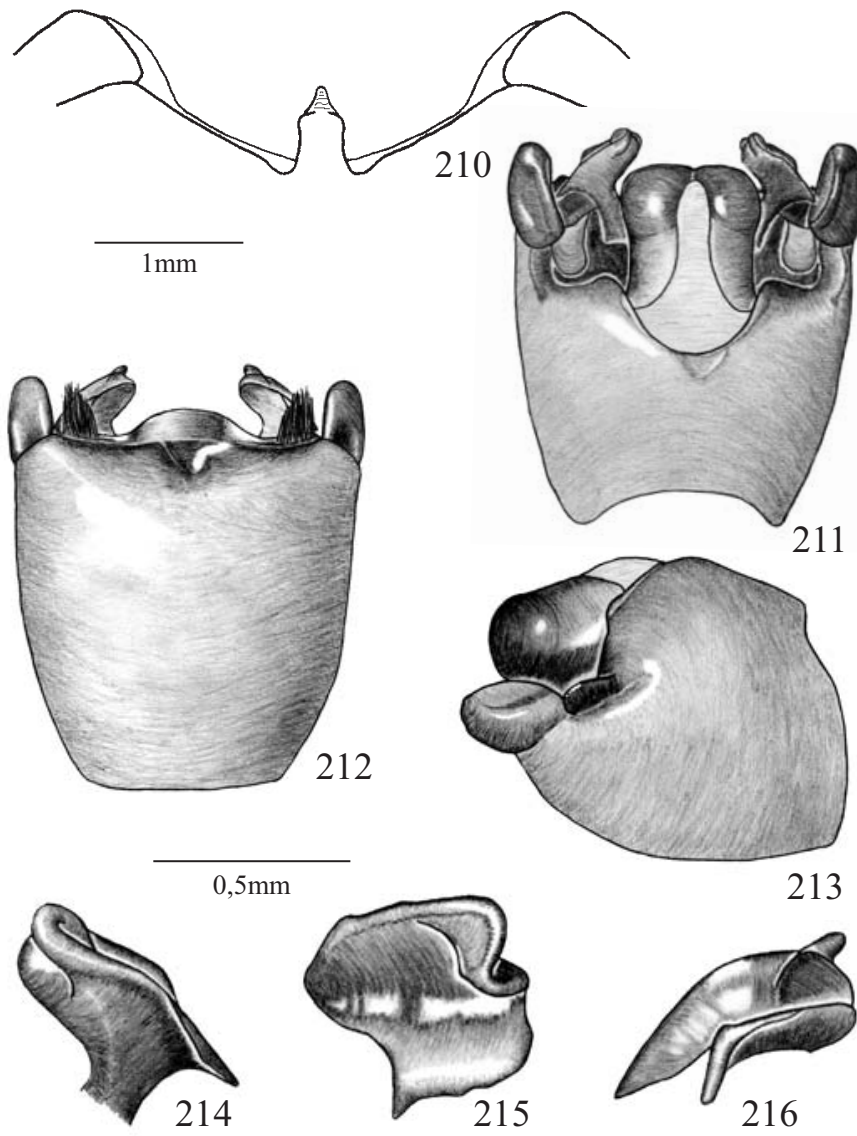

Figs. 210-216. Antiteuchus melanicus sp. nov. 210, Processo mediano do tergito VII; 211-213, Pigóforo em vistas dorsal, ventral e lateral, respectivamente; 214-216, Parâmero em vistas dorsal, posterior e ventral, respectivamente.

ventralmente; ápice não expandido, margem posterior profundamente sulcada formando um processo bilobado no ápice. Processo mediano ultrapassando pouco a margem da membrana (fig. 154).

Pigóforo amarelo-escuro e sem um tufo de pêlos na lateral, junto ao ângulo póstero-lateral do pigóforo. Processo láterodorsal pouco desenvolvido, caracterizado pela ausência de uma elevação na parede do pigóforo quando se observa em vista lateral, e não projetado sobre a base do ângulo pósterolateral do pigóforo (fig. 157). Projeções do bordo dorsal, laterais ao segmento $\mathrm{X}$, avançando em direção aos tubérculos deste (fig. 155). Bordo ventral trapezoidal, estreito, plano, margem superior reta e mais larga que extremidade do segmento $\mathrm{X}$, em cada margem lateral se encontra uma elevação com textura diferente do restante e recoberta por um tufo de pêlos longos (figs. 156). Superfície ventral do pigóforo, logo abaixo do bordo ventral, apresentando uma área mediana côncava, margeada por pontuação castanha, recoberta por pêlos esparsos e apresentando uma área mediana pouco elevada. Ângulo póstero-lateral do pigóforo, em vista lateral, sub-retangular e cerca de 2 vezes mais longo que largo; curvado internamente na metade posterior obstruindo a visão da taça genital; ápice 
com uma aba transversal pouco achatada, larga e projetada látero-dorsalmente. Face interna de cada ângulo póstero-lateral do pigóforo plana e apresentando na margem ventral interna um tubérculo grande próximo ao ápice. Face dorsal convexa com exceção de uma área escavada acima da prega em declive, observando-a da margem externa para interna, e apresentando alguns sulcos longitudinais; ápice e margem interna castanhoescuras.

Cabeça do parâmero (figs. 158-160) composta por 4 lobos aparentes. Dorsal largo, delgado, inteiro e curvado, ápice apresentando uma área expandida dividida em duas partes, uma interna, curvada ventralmente e colocada em um plano mais baixo que a externa, que é também menos curvada; carena dorsal baixa e terminando sobre a área expandida. Lobo lateral interno curto, retangular, delgado, estreito e curvado posteriormente. Lobo lateral externo pouco desenvolvido, ovalado, com uma pequena projeção látero-dorsal, apresentando uma grande área intumescida junto a base e levemente curvado lateralmente. Lobo ventral reduzido a um pequeno processo espiniforme com a margem negra.

Tubérculos do segmento $\mathrm{X}$ achatados, dirigidos dorsoposteriormente e implantados obliquamente sobre o segmento $\mathrm{X}$ (figs. 155). Face posterior levemente convexa, muito inclinada, quase perpendicular ao plano frontal do pigóforo; carenas laterais pouco desenvolvidas; crista mediana percorrendo toda face. Área membranosa dorsal terminando adiante da base dos tubérculos.

Holótipo macho. "Leticia, Colombia, Prov. Amazonas, April 2-7, 1975, D. Engleman" (NMNH). Examinado.

Distribuição: Colômbia, Amazonas: Leticia. Equador, Pastaza: Puyo; Napo: Coca.

Comentários: Os exemplares analisados pertencem às coleções do AMNH, BMNH e NMNH. Esta espécie pode ser identificada pela forma convexa das áreas recobertas por pêlos da superfície ventral do pigóforo; pelo lobo dorsal do parâmero largo e curvado; pelo lobo lateral interno curto, retangular, estreito e curvado posteriormente; pelo lobo ventral reduzido a um pequeno processo espiniforme com a margem negra.

\section{Grupo A. tesselatus}

(Figs. 161-181,305)

Corpo ovalado, achatado dorso-ventralmente, amarelo a amarelo-escuro e brilhante. Pontuação distribuída em linhas sinuosas transversais, principalmente sobre pronoto e escutelo, ou formando agrupamentos irregulares, principalmente sobre o hemiélitro. Os pontos são recobertos por faixas castanhas a negras dando ao corpo um aspecto variegado.

Disco pronotal com manchas escuras entremeadas por manchas amarelas. Hemiélitro com ápice atingindo a metade posterior do conexivo VII; pontuação irregularmente distribuída, formando dois grandes agrupamentos laterais à linha mediana transversal e outros menores dispersos sobre

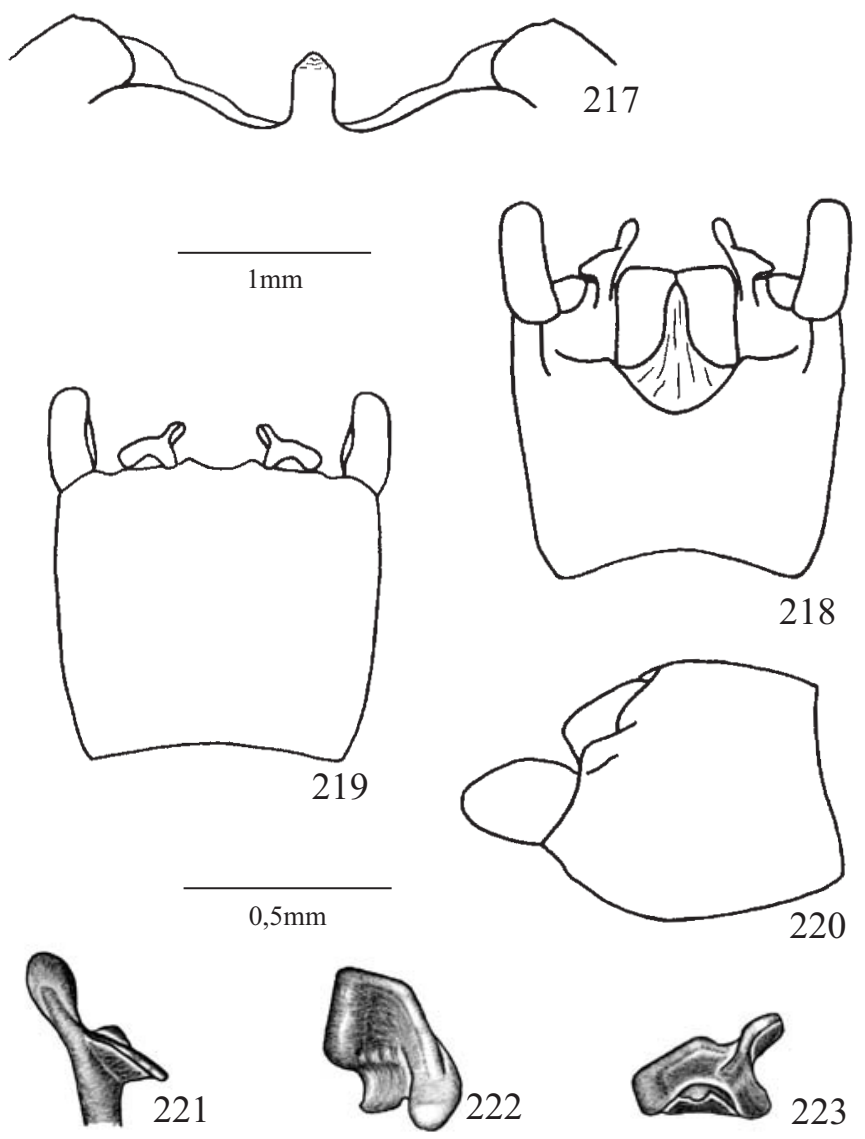

Figs. 217-223. Antiteuchus fulvescens. 217, Processo mediano do tergito VII; 218-220, Pigóforo em vistas dorsal, ventral e lateral, respectivamente; 221-223, Parâmero em vistas dorsal, posterior e ventral, respectivamente.

toda superfície. Estes agrupamentos de pontos são recobertos por manchas castanho-escuras. Escutelo com ápice arredondado e atingindo a metade distal do urotergito VII; possui uma mancha, variável em tamanho, castanha a castanhoescura localizada no 1/3 basal, entremeada por áreas amarelas. Ventralmente o tórax é amarelo com manchas escuras. Margem externa do pronoto ventral sem pontuação e com manchas mais claras que no restante. Área evaporatória castanho-clara. Ruga ostiolar amarelo-pálida. Meso e metapleura com um calo amarelo-pálido. Pernas amarelas a castanho-claras com manchas escuras nos fêmures e tíbias. Pêlos das tíbias com comprimento menor que o diâmetro do segmento. Coloração dorsal do abdome castanha com margem castanho-escura. Face ventral amarela recoberta por manchas castanho-claras que diminuem de densidade da margem lateral para região mediana.

Uma linha imaginária tangente à margem posterior do conexivo VII, não secciona o ângulo póstero-lateral do urotergito VII. Urotergito VII com um par de projeções triangulares laterais ao processo mediano, sem impressões ou processos espessados na margem. Processo mediano do urotergito VII com parte livre curta, estreita, muito convexa 
transversalmente, reta e dirigida póstero-ventralmente, ápice expandido, margem posterior inteira, curvada ventralmente e sem uma lígula membranosa. Membrana desenvolvida, sem pêlos, estendendo-se por todo segmento e com uma área escura em cada 1/3 lateral. Margem posterior da membrana coincidindo com o final do processo (figs. 161, 168, 171).

Pigóforo com um grupo de pêlos curtos na lateral, junto ao ângulo póstero-lateral. Processo látero-dorsal desenvolvido, arredondado e não fundido à base do ângulo póstero-lateral do pigóforo (figs. 164, 171, 178). Bordo dorsal sem áreas intumescidas laterais ao segmento $\mathrm{X}$. Bordo dorsal com expansões dentiformes, laterais ao segmento X, não projetadas em direção aos tubérculos deste (figs. 162, 169, 176). Diafragma sem processos membranosos. Bordo ventral estreito e com a margem levemente dobrada posteriormente. Sobre a superfície ventral ocorrem duas grandes áreas intumescidas, localizadas junto aos ângulos póstero-laterais do pigóforo (fig. 163); entre elas ocorre uma pequena concavidade sem uma área elevada central e recoberta por pêlos esparsos. Em vista dorsal é possível ver que o bordo ventral avança anteriormente sobre a taça genital, fundindo-se a base de cada ângulo pósterolateral do pigóforo e apresentando uma superfície plana ou levemente ondulada (figs. 162, 176). Ângulo póstero-lateral do pigóforo ogival, em vista lateral, em torno de 1,5 vezes mais longo que largo, em vista lateral, levemente achatado lateralmente, reto, paralelo ao outro processo e sem carenas ou tubérculos (fig. 164, 171, 178). Face externa levemente convexa, com poucos pontos recobertos por manchas castanhas e vários sulcos longitudinais. Ângulo pouco mais longo que a área esclerotizada do segmento X e implantado no plano longitudinal do pigóforo.

Parâmero apresentando a cabeça perpendicular ao seu eixo longitudinal. Cabeça composta por 4 lobos: dorsal, lateral externo, lateral interno e ventral. Lobo dorsal do parâmero (ld) projetado ventralmente formando uma área curvada, sinuosa e que atinge ou ultrapassa o nível dos lobos ventral (lv) e lateral externo (le), em vista posterior (figs. 166, 180). Lobo lateral interno (li) curvado e projetado ventralmente em direção ao segmento $\mathrm{X}$, sendo completamente encoberto pelo lobo dorsal em vista posterior (figs. 165-167). Margem lateral interna do lobo dorsal sem carenas.

Segmento X globoso, recoberto por pêlos esparsos na face posterior, tubérculos e margem ventral; sem áreas dorsolaterais intumescidas. Tubérculos bem desenvolvidos, digitiformes, levemente achatados, dirigidos posteriormente, implantados obliquamente sobre o segmento X. Face posterior plana, muito inclinada quase perpendicular ao plano frontal do pigóforo e sem área intumescida na extremidade posterior; carenas laterais pouco desenvolvidas, convergentes em direção a base; sem crista mediana ou área intumescida junto a base (figs. 162, 169, 176). Área membranosa terminando entre os tubérculos.

Comentários: Este grupo é composto por três espécies: $A$. tesselatus, $A$. marini sp. nov.e $A$. simulatus sp. nov., tendo como características diagnósticas a margem do urotergito VII com um par de projeções triangulares laterais ao processo

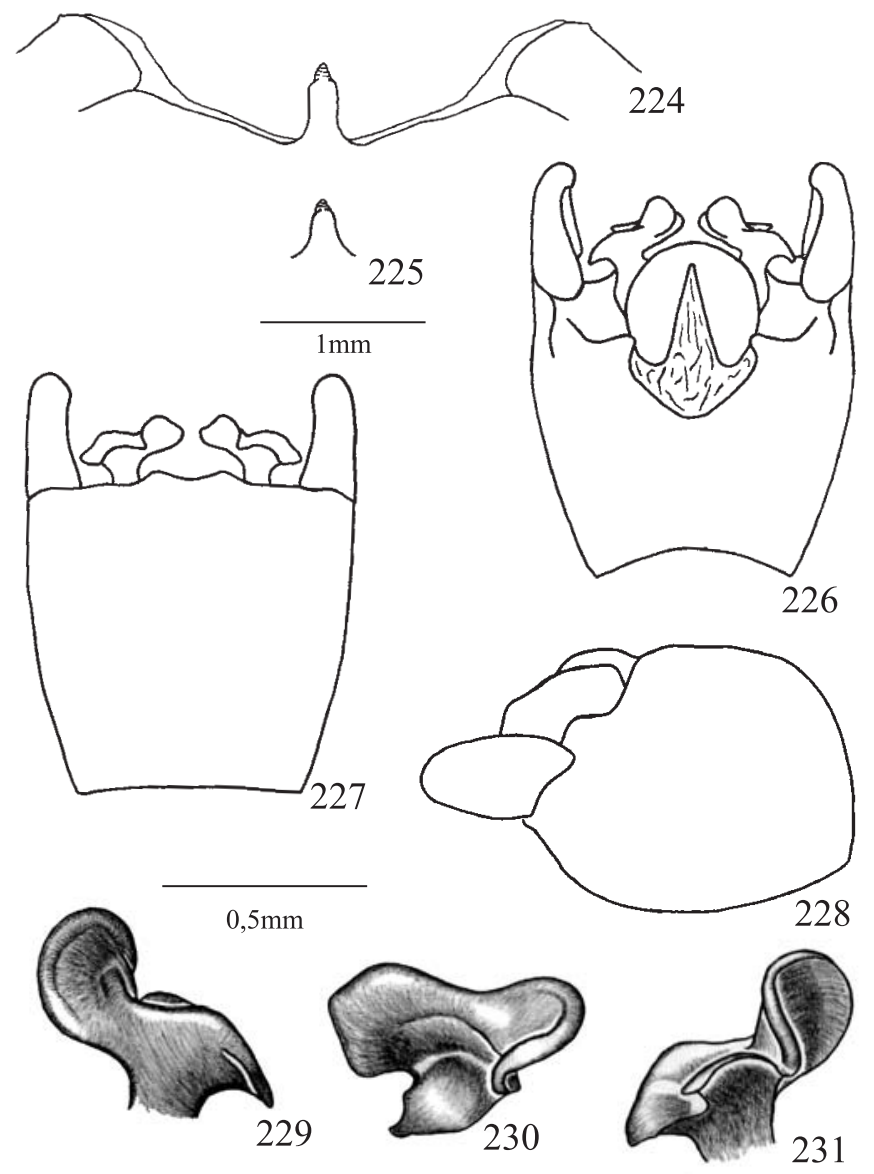

Figs. 224-231. Antiteuchus tripterus. 224-225, Duas formas do processo mediano do tergito VII; 226-228, Pigóforo em vistas dorsal, ventral e lateral, respectivamente; 229-231, Parâmero em vistas dorsal, posterior e ventral, respectivamente.

mediano; superfície ventral com um par de áreas intumescidas junto a cada ângulo póstero-lateral do pigóforo e bordo ventral (fig. 163); bordo ventral avançando anteriormente sobre a taça genital, fundindo-se a base de cada ângulo póstero-lateral do pigóforo e apresentando uma superfície plana ou levemente ondulada, em vista dorsal; ângulo póstero-lateral do pigóforo curto, cerca de 1,5 vezes mais longo que largo, em vista lateral, reto, com ápice levemente intumescido e sem carenas ou tubérculos; forma curvada e projetada do lobo dorsal do parâmero que recobre o lobo lateral interno em vista posterior; lobo ventral do parâmero longo, curvado lateralmente e achatado; segmento X globoso, recoberto por pêlos esparsos e sem crista mediana.

\section{Chave de identificação para os machos das espécies do grupo A. tesselatus}

1. Face dorsal do ângulo póstero-lateral do pigóforo com uma prega. Lobo ventral do parâmero curto e reto (figs. 162, 166)..... A. tesselatus

Face dorsal do ângulo póstero-lateral do pigóforo sem prega e com um sulco longitudinal. Lobo ventral do 
parâmero longo e curvado lateralmente (figs. 174, 176) 2

2(1). Processo mediano do urotergito VII plano. Projeção ventral do lobo dorsal do parâmero estreita e não ultrapassando o lobo ventral em vista posterior (figs. 173) A. marini sp. nov.

Processo mediano do urotergito VII fortemente convexo transversalmente. Projeção ventral do lobo dorsal do parâmero larga e ultrapassando muito o lobo ventral em vista posterior (figs. 180) .....A. simulatus sp. nov.

Antiteuchus tesselatus (Westwood, 1837)

(Figs. 161-167, 305)

Dinidor tesselatus Westwood, 1837: 24-25.

Macrothyreus annulicornis Fieber, 1852: 458; Stål, 1872: 9.

Dinocoris tesselatus; Stål, 1872: 9; Lethierry \& Severin, 1893: 86.

Mecistorhinus tesselatus; Kirkaldy, 1909: 218.

Gringerda annulicornis; Kirkaldy, 1909: 218.

Antiteuchus annulicornis; Ruckes, 1961: 152.

Antiteuchus tesselatus; Ruckes, 1961: 152.

Antiteuchus (Antiteuchus) tesselatus; Ruckes, 1964: 84 (chave), 88-

89, figs. 50-52; Rolston, 1993: 110 (chave), 117-118, figs. 32-35.

Medidas ( $\mathrm{n}=5)$ : comprimento total- 12,8-14,8; largura total7,4-7,9.

Segmento antenal I amarelo com manchas escuras. Segmentos II e III negros com uma pequena área lateral amarela. Segmento IV com o 1/3 basal amarelo e o restante negro. Segmento $\mathrm{V}$ amarelo com um anel negro próximo ao ápice, região apical amarelo-escura. Segmentos em ordem crescente de comprimento: II; I; III; IV e V subiguais.

Conexivo exposto, áreas intersegmentares negras alternadas com áreas amarelas; pontuação castanho-clara e não interligada. Processo mediano do urotergito VII com parte livre estreita e convexa (fig. 161).

Pigóforo amarelo. Escavação do bordo dorsal mais profunda que larga (fig. 162). Bordo ventral biconvexo, margem superior côncava e tão larga quanto a extremidade do segmento X (fig. 163). Face dorsal de cada ângulo póstero-lateral do pigóforo convexa, estreita e com uma prega descendente. Face interna plana, ápice levemente intumescido e com manchas castanhas, margem ventral interna castanho-escura.

Lobo dorsal do parâmero (figs 165-167) amplo, delgado, convexo transversalmente e projetado ventralmente; esta projeção é longa, lingüiforme, estreita e levemente côncava transversalmente, ultrapassando o lobo ventral em vista posterior. Carena dorsal baixa e evanescente na base do lobo dorsal. Lobo lateral externo pouco desenvolvido, lingüiforme, convexo transversalmente e curvado látero-anteriormente. Lobo ventral curto, delgado, afilado em direção ao ápice, plano ou levemente convexo transversalmente e dirigido para base do ângulo póstero-lateral do pigóforo.

Holótipo macho. "Brasilia", "tesselatus Hope", "Dinocoris tesselatus Westwood”, “Type Westwood (Hope) C. Hemipt. 1837 Part I, page 24; Distant, PZS, 1900, p. 807-825", Type Hem n 106 Dinidor tesselatus Westwood Hope Dept. Oxford" (OXUM). Examinado.

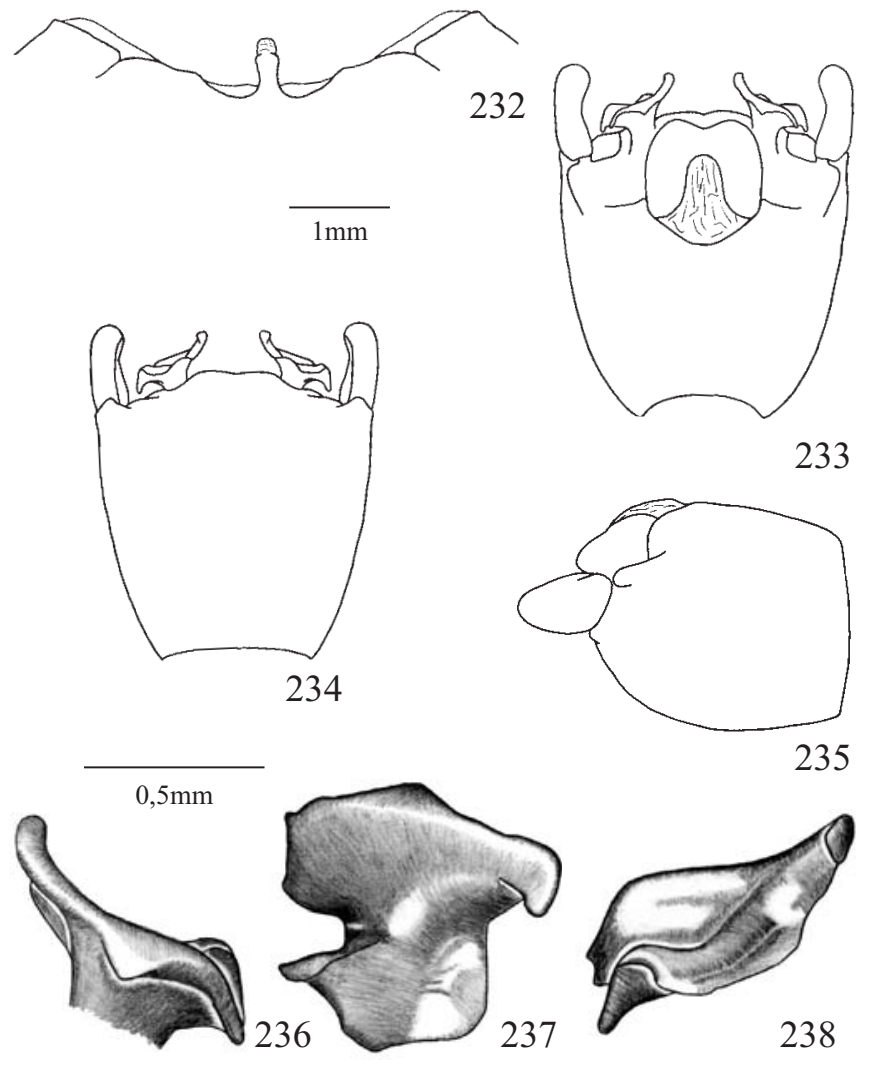

Figs. 232-238. Antiteuchus maculosus. 232, Processo mediano do tergito VII; 233-235, Pigóforo em vistas dorsal, ventral e lateral, respectivamente; 236-238, Parâmero em vistas dorsal, posterior e ventral, respectivamente.

Distribuição: Brasil, Espírito Santo: Linhares, Itapina; Rio de Janeiro: Rio de Janeiro.

Comentários: Os exemplares analisados pertencem às coleções do AMNH, CASC, DZUP e FIOC. Esta espécie distingue-se das outras do grupo pelo tamanho maior do artículo antenal I em relação ao II; pela presença de uma prega sobre a face dorsal de cada ângulo póstero-lateral do pigóforo; pela projeção ventral do lobo dorsal do parâmero levemente convexa transversalmente e ultrapassando pouco o lobo ventral, em vista posterior; pelo lobo lateral externo do parâmero pouco desenvolvido, lingüiforme e convexo transversalmente; pelo lobo ventral curto e dirigido para base do ângulo pósterolateral do pigóforo. A tesselatus e $A$. simulatus apresentam como característica comum o processo mediano do urotergito VII fortemente convexo transversalmente. A tesselatus e $A$. marini apresentam como característica comum o bordo ventral côncavo.

\section{Antiteuchus marini sp. nov.}

(Figs. 168-174, 305)

Etimologia. Homenagem póstuma a Augilio Marin.

Medidas ( $\mathrm{n}=8)$ : comprimento total- 11,5-12,6; largura total7,2-7,7. 
Segmento antenal I amarelo com manchas escuras. Segmento II negro com uma área lateral amarela. Segmento III negro. Segmento IV negro com o 1/3 basal amarelo. Segmento $\mathrm{V}$ amarelo com um anel negro próximo ao ápice, região apical amarelo-escura. Segmentos em ordem crescente de comprimento: I e II subiguais; III; IV e V subiguais.

Conexivo exposto, áreas intersegmentares negras alternadas com áreas amarelo-escuras; pontuação castanhoclara interligada por faixas de mesma cor. Processo mediano do urotergito VII com parte livre larga e plana (fig. 168).

Pigóforo amarelo-escuro. Escavação do bordo dorsal tão profunda quanto larga (fig. 169). Bordo ventral biconvexo, margem superior côncava e tão larga quanto a extremidade do segmento X (fig. 170). Face dorsal do ângulo póstero-lateral do pigóforo plana, estreita, com um sulco mediano longitudinal e sem uma prega. Face interna plana; ápice com uma pequena área intumescida, quase inconspícua, e castanho-escura; margem ventral interna castanho-escura.

Lobo dorsal do parâmero (figs. 172-174) amplo, delgado, convexo transversalmente e projetado ventralmente; esta projeção é longa, lingüiforme, estreita e côncava transversalmente, não ultrapassando o lobo ventral em vista posterior. Carena dorsal alta e evanescente na base do lobo dorsal. Lobo lateral externo desenvolvido e composto por duas partes, uma pequena, subtriangular, delgada e dirigida lateralmente; e outra maior, ampla, lingüiforme e dirigida láteroanteriormente. Lobo ventral longo, delgado, afilado em direção ao ápice, plano ou levemente convexo transversalmente e curvado lateralmente.

Holótipo macho: BRASIL, Pará: Soure (Ilha de Marajó), 25-II1979, P. Nolasco (MPEG). Parátipos: BRASIL, Pará: Soure (Ilha de Marajó), 24-II-1979, P. Nolasco, 1 fêmea (MPEG); Soure, 23-II-1979, 1 macho (UFRG); Peixeboi, 15-IV-1977, M. F. Torres, 1 fêmea (MPEG); Castanhal, 1978, Mendes, A. C., 1 fêmea (MPEG); Benevides, Morelândia, 7-VII-1988, J. Dias, 1 fêmea (MPEG); Belém, Mocambo, 11-III-1978, mata de terra firme, armadilha de Malaise, 1 macho (RMNH). Maranhão: São Luis, 24-X-1984, AL 11-8823, A. Brisolla col., 1 macho (IBSP).

Distribuição: BRASIL, Pará: Soure, Peixeboi, Castanhal, Belém, Benevides; Maranhão: São Luis.

Comentários: Os exemplares analisados pertencem às coleções do IBSP, MPEG e UFRG. Esta espécie distingue-se das outras do grupo por apresentar os artículos antenais I e II subiguais em comprimento; pelo processo mediano do urotergito VII plano; pela projeção ventral do lobo dorsal do parâmero estreita e não ultrapassando o lobo ventral em vista posterior; pelo lobo lateral externo desenvolvido e composto por duas partes. A. marini e A. simulatus compartilham a ausência de uma prega sobre a face dorsal de cada um dos ângulos póstero-laterais; a face dorsal do ângulo pósterolateral do pigóforo plana, estreita e com um sulco mediano longitudinal; o ápice de cada ângulo póstero-lateral do pigóforo com uma área intumescida quase inconspícua.

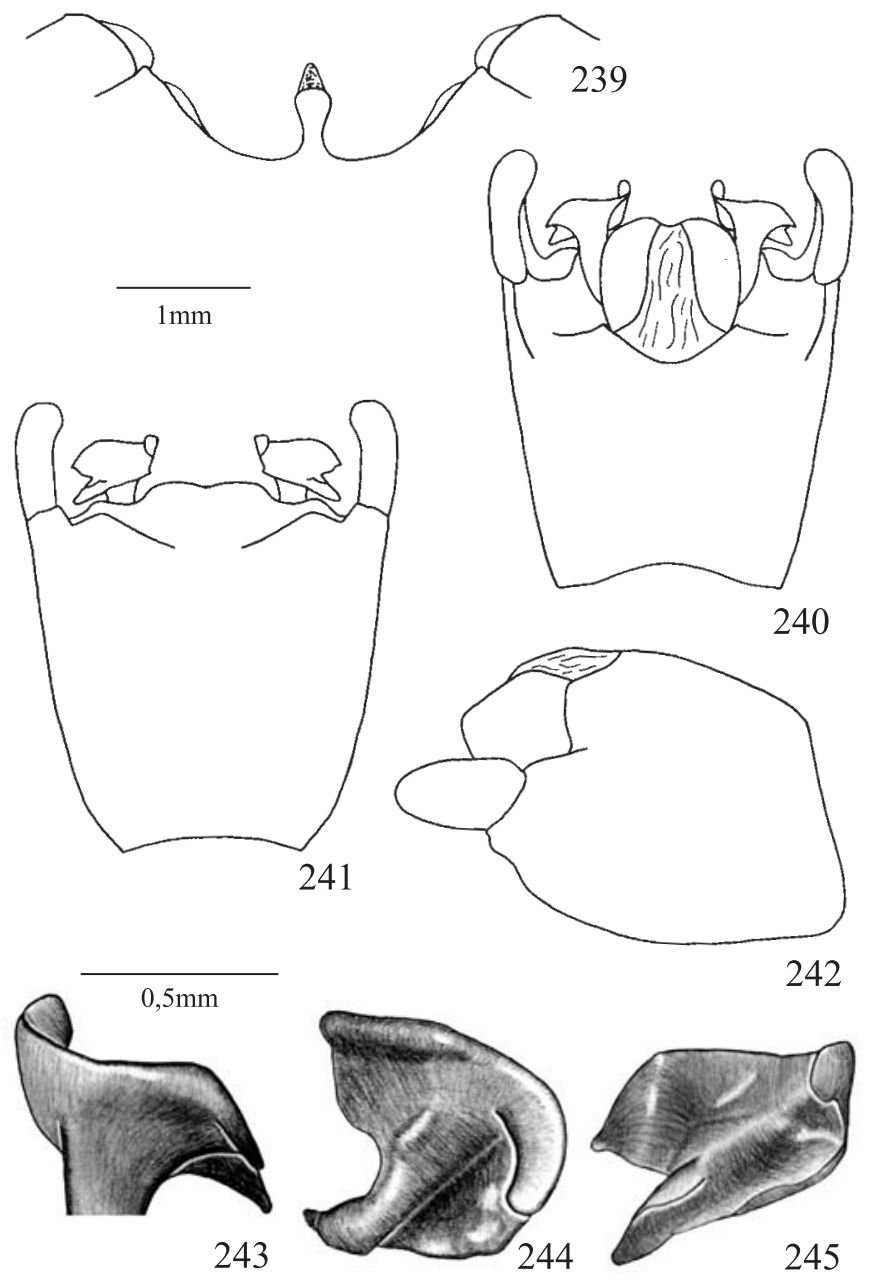

Figs. 239-245. Antiteuchus panamensis. 239, Processo mediano do tergito VII; 240-242, Pigóforo em vistas dorsal, ventral e lateral, respectivamente; 243-245, Parâmero em vistas dorsal, posterior e ventral, respectivamente.

Antiteuchus simulatus sp. nov.

(Figs. 175-181, 305)

Etimologia. Nome indica a grande semelhança com $A$. tesselatus e A. marini.

Medidas ( $\mathrm{n}=18)$ : comprimento total- 11,2-12,0; largura total7,2-7,9.

Segmento antenal I amarelo com manchas escuras. Segmento II amarelo-escuro com manchas negras. Segmentos III e IV negros com um anel amarelo na base. Segmento V amarelo com um anel negro próximo ao ápice, região apical amarelo-escura. Segmentos em ordem crescente de comprimento: I; II; III; IV e V subiguais.

Conexivo exposto, áreas intersegmentares negras alternadas com áreas amarelo-escuras; pontuação castanhoclara interligada por faixas de mesma cor. Processo mediano do urotergito VII com parte livre larga e muito convexa transversalmente (fig. 175). 
Pigóforo amarelo. Escavação do bordo dorsal quase tão larga quanto profunda (fig. 176). Bordo ventral trapezoidal, margem superior reta ou levemente côncava e mais larga que a extremidade do segmento X (fig. 177). Face dorsal do ângulo póstero-lateral do pigóforo convexa, estreita, com um sulco mediano longitudinal e sem uma prega. Face interna convexa; ápice com uma pequena área intumescida, quase inconspícua, e com manchas castanho-escuras na extremidade; margem ventral interna castanha.

Lobo dorsal do parâmero (figs. 179-181) amplo, delgado, convexo transversalmente e projetado ventralmente; esta projeção é longa, lingüiforme, larga e côncava transversalmente, ultrapassando muito o lobo ventral em vista posterior. Carena dorsal alta e evanescente na base do lobo dorsal. Lobo lateral externo desenvolvido, arredondado, levemente convexo e curvado látero-dorsalmente. Lobo ventral longo, delgado, afilado em direção ao ápice, plano ou levemente convexo transversalmente e curvado lateralmente.

Holótipo macho: Brasil, Pará: Medicilândia, Rodovia Transamazônica (BR 230), km 70-101, X-1980, A.C. Mendes (MPEG). Parátipos: Brasil, Amazonas: Manaus, Rod. Manaus-Itacoatiara km 30, X-1979, A. C. Mendes, 1 fềmea (INPA), 1 fềmea (MPEG); Pará: Melgaço, Floresta Nacional de Caxiuanã, Estação Científica Ferreira Pena, heliporto, XI-2003, J. A. M. Fernandes, 1 macho (MPEG); Altamira, Rodovia Transamazônica (BR 230) km 65, 28-II-1979, A. C. Mendes, 1 macho (AMNH); Medicilândia, Rodovia Transamazônica, km 79, XI-1982, Biccelli, 1 fêmea (MZSP); idem, km 95, 1979, Biccelli, 1 macho e 1 fêmea (MPEG), 1 macho e 1 fêmea (UFAM) 2 machos (UFRG), 1 macho (INPA); idem, km 100, VI-1979, A. C. Mendes, 1 fêmea (UFRG); Tucuruí, I-1979, M. Alvarenga, 1 macho (MZSP); Rondônia: Ouro Preto d'Oeste, 1980, A. C. Mendes, 1 macho (MPEG); Mato Grosso: Porto Velho, Rio Tapirapé, 30-XII-1964, R. T. Lima, 1 fêmea (MZSP); Sinop, 12³1'S 55³7’W, X-1974, M. Alvarenga, J. A. Slater collection, 1 fêmea (AMNH).

Distribuição: BRASIL, Amazonas: Manaus; Pará: Castanhal, Altamira, Medicilândia, Tucuruí; Rondônia: Ouro Preto d'Oeste; Mato Grosso: Porto Velho, Sinop.

Comentários: Os exemplares analisados pertenciam às coleções da UFRG, AMNH e MZSP. Esta espécie distingue-se das demais por apresentar o artículo antenal II maior que o I; bordo ventral do pigóforo trapezoidal; projeção ventral do lobo dorsal larga e ultrapassando muito o lobo ventral em vista posterior; lobo lateral externo do parâmero desenvolvido, arredondado e levemente convexo.

\section{Grupo A. marmoratus}

Este grupo é composto somente por A. marmoratus, portanto a descrição e comentários são apresentados apenas para espécie.

Antiteuchus marmoratus (Erichson, 1848)

(Figs. 182-188, 305)

Cataulax marmoratus Erichson, 1848: 609.

Dinocoris (Mecistorhinus) marmoratus; Stål, 1872: 8

Dinocoris marmoratus; Lethierry \& Severin, 1893: 86 (catálogo).

Mecistorhinus (Mecistorhinus) marmoratus; Kirkaldy, 1909: 217 (catálogo).

Antiteuchus marmoratus; Ruckes, 1961: 152.
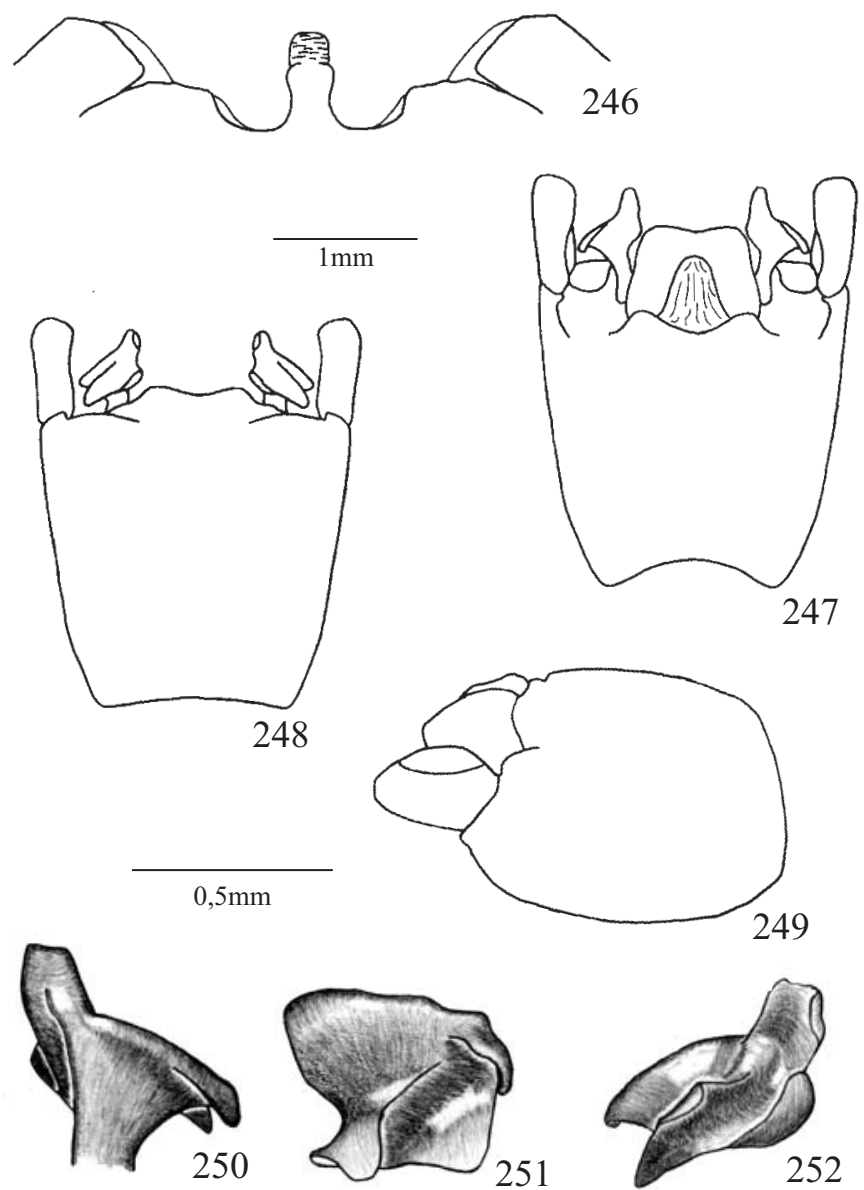

Figs. 246-252. Antiteuchus costaricensis. 246, Processo mediano do tergito VII; 247-249, Pigóforo em vistas dorsal, ventral e lateral, respectivamente; 250-252, Parâmero em vistas dorsal, posterior e ventral, respectivamente.

Antiteuchus (Antiteuchus) marmoratus; Ruckes, 1964: 84 (chave), 8788; Froeschner, 1981: 64 (lista); Rolston, 1993: 110 (chave), 126127 , figs. $52-53$

Antiteuchus (Antiteuchus) ratcliffei Engleman, 1983: 184, figs. 13, 17; Rolston, 1993: 126.

Medidas do holótipo: comprimento total- 11,5; largura total- 7,2.

Corpo ovalado, achatado dorso-ventralmente, amarelo escuro e brilhante. Pontuação densa e homogênea, distribuída em linhas sinuosas e transversais recobertas por faixas castanho-escuras que variam de largura entre uma e duas vezes o diâmetro do ponto. Presença de manchas mais escuras sobre pronoto, escutelo e hemiélitros. Segmentos I e II amareloescuros apresentando pequenas manchas negras. Segmentos III e IV negros com um anel amarelo-pálido na base. Artículos antenais em ordem crescente de comprimento: I; II; III; IV. Artículo V ausente, segundo Ruckes (1964) IV e V subiguais em comprimento.

Clípeo mais escuro que o restante da cabeça. Rostro amarelo. Disco pronotal apresentando a metade posterior mais escura que a anterior. Cicatrizes do pronoto pouco evidentes e 
delimitadas por pontuação. Hemiélitro com ápice atingindo a metade posterior do segmento VII do conexivo; apresenta uma mancha mediana na metade basal; pontuação esparsa e irregularmente distribuída. Escutelo com ápice arredondado, atingindo a metade posterior do segmento abdominal VII. Ventralmente o tórax apresenta pontuação mais concentrada nos $2 / 3$ laterais da pleura onde a coloração dos pontos e das faixas que os unem é mais escura. Mesopleura com um pequeno calo amarelado dentro da área evaporatória. Metapleura com um grande calo amarelado junto a margem lateral. Coxas e trocânteres amarelos e imaculados. Fêmures com muitas manchas castanho-escuras. Tíbias com muitas manchas na superfície dorsal e praticamente imaculadas na ventral; pêlos com comprimento menor que o diâmetro da tíbia. Tarsos amarelo-escuros e imaculados. Conexivo apresentando manchas negras nas regiões intersegmentares alternadas com manchas amarelo-escuras no disco dos segmentos. Coloração dorsal do abdome castanha. Face ventral do abdome amarela recoberta por manchas castanho-claras que diminuem de densidade da margem lateral para região mediana. Ângulos póstero-laterais de cada segmento escuros. Ocorre uma faixa lateral larga, que inclui os espiráculos, onde os pontos são negros. Região calosa, interna a cada espiráculo, amarelopálido. Uma linha imaginária tangente à margem posterior do conexivo VII, não secciona o ângulo póstero-lateral do urotergito VII. Urotergito VII sem impressões, projeções laterais ao processo mediano ou espessamentos no 1/4 lateral. Processo mediano bem desenvolvido, digitiforme, longo, estreito, reto e dirigido póstero-ventralmente, ápice levemente dilatado, inteiro, curvado ventralmente e sem uma lígula pouco esclerotizada na margem posterior. Membrana bem desenvolvida, estendendo-se de um lado a outro do segmento e sem pêlos. Processo ultrapassando muito a margem da membrana, pelo menos duas vezes seu comprimento (fig. 182).

Pigóforo (figs. 183-185) com um tufo de pêlos longos na lateral, junto ao ângulo póstero-lateral do pigóforo. Processo látero-dorsal desenvolvido, formado por uma pequena elevação que atinge a base do ângulo póstero-lateral do pigóforo. Bordo dorsal sem áreas intumescidas laterais ao segmento X. Projeções do bordo dorsal, laterais ao segmento $\mathrm{X}$, dentiformes e não projetadas em direção aos tubérculos deste. Escavação do bordo mais larga do que profunda. Diafragma sem processos membranosos. Folheto interno do bordo ventral projetado dorso-anteriormente formando um processo esclerotizado, escuro, arredondado no ápice e com uma protuberância basal localizado junto ao ângulo pósterolateral do pigóforo (processo superior do bordo ventral- psbv) (fig. 183). Bordo ventral côncavo, estreito e levemente convexo transversalmente; margem superior mais larga que a extremidade do segmento $X$; não ocorre nenhum tipo de projeção ou tufo de pêlos sobre a superfície ventral. Superfície ventral, logo abaixo do bordo ventral, apresentando uma concavidade mediana com uma área elevada central, recoberta por pêlos esparsos. Ângulo póstero-lateral do pigóforo ogival, em vista lateral, 1,5 vezes mais longo que largo, em vista lateral, retos, paralelos e com ápice intumescido. Face dorsal plana e com

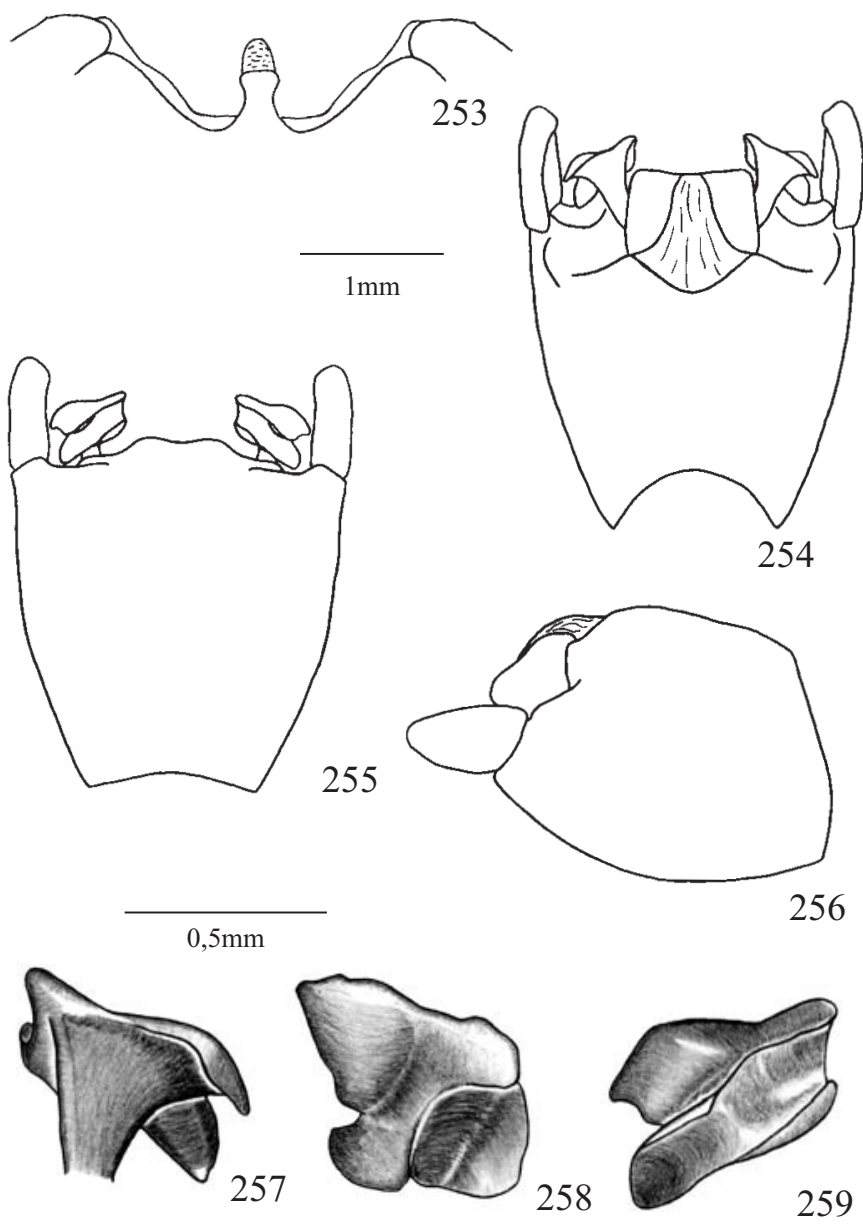

Figs. 253-259. Antiteuchus innocens. 253, Processo mediano do tergito VII; 254-256, Pigóforo em vistas dorsal, ventral e lateral, respectivamente; 257-259, Parâmero em vistas dorsal, posterior e ventral, respectivamente.

uma prega transversal descendente, observando-a da margem externa para interna. Face lateral interna plana e sem carenas, dentes ou tubérculos na margem interna. Face lateral externa e ventral convexas e com alguns pontos recobertos por manchas castanhas. Ângulo mais longo que a parte esclerotizada do segmento X e implantado na linha transversal do pigóforo.

Cabeça do parâmero (figs. 186-188) perpendicular ao eixo longitudinal do parâmero e composta por 3 lobos. Dorsal alongado, convexo transversalmente, largo, sem carenas e curvado posteriormente. Lobo lateral externo arredondado, levemente convexo e com uma escavação rasa na base. Lobo ventral, arredondado, côncavo e com uma projeção espiniforme, longa e dirigida para base do ângulo pósterolateral do pigóforo.

Segmento X (fig. 183) globoso, totalmente recoberto por pêlos, sem áreas intumescidas dorso-laterais. Tubérculos bem desenvolvidos, triangulares, achatados, dirigidos dorsoposteriormente e implantados obliquamente sobre o segmento $\mathrm{X}$. Face posterior plana, muito inclinada quase perpendicular ao plano longitudinal e sem carenas laterais, crista mediana ou 
área intumescida ventral. Área membranosa dorsal terminando adiante dos tubérculos.

C. marmoratus: Holótipo macho. "British Guiana, Schomh.”, "Zool Mus. Berlin" (ZMHB). Examinado.

A. ratcliffei: Holótipo macho. "Bartica Dist. Brit. Guiana" "Brit. Mus. 1954-631” (BMNH). Examinado.

Distribuição: Guiana.

Comentários: Espécie conhecida apenas pelos holótipos de $C$. marmoratus e A. ratcliffei. Esta espécie pode ser reconhecida por apresentar o processo mediano do urotergito VII digitiforme e longo, pelo menos duas vezes maior que a largura da membrana, ápice levemente dilatado e curvado ventralmente; pelos ângulos póstero-laterais do pigóforo cerca de 1,5 vezes mais longos que largos em vista lateral, retos, paralelos e com ápice intumescido; pela forma do parâmero; pelo segmento X globoso, recoberto por densa pubescência e com tubérculos triangulares; pela face posterior do segmento X plana, sem carenas laterais ou crista mediana. Ruckes (1964) considerou esta espécie como sendo "o meio da série filética" entre as espécies dos grupos "incurvaria" e "parallela", propostos por ele. O grupo marmoratus é composto apenas pela espécie nominal e, de fato, apresenta características comuns aos diferentes grupos de espécies aqui propostos. Por exemplo, compartilha com os grupos já apresentados a escavação do bordo dorsal do pigóforo mais larga que profunda; membrana do urotergito VII larga e sem pêlos; presença de tubérculos sobre o segmento X. A. marmoratus compartilha com as espécies do grupo mixtus o segmento $\mathrm{X}$ recoberto por densa pubescência; lobo ventral do parâmero apresentando uma projeção lateral; presença do processo superior do bordo ventral.

\section{Grupo A. mixtus}

(Figs. 189-301, 306-310)

Artículos antenais II e III apresentam setas, pêlos eriçados tão ou pouco mais longos que o diâmetro do segmento ao qual estão fixados, exceto $A$. mixtus e $A$. radians. Margem lateral do pronoto ventral sem pontuação e com manchas mais claras que no restante do segmento. Metapleura sem uma grande área calosa e amarela junto à margem externa, com exceção de e $A$. melanoleucus, $A$. mixtus, $A$. radians, $A$. macraspis, $A$. schuhi e $A$. variegatus. Tíbias com pêlos mais longos que o diâmetro do segmento, exceto $A$. mixtus e $A$. radians. Face ventral do abdome castanha a castanho-escura clareando em direção à região mediana. Uma linha imaginária tangente à margem posterior do conexivo VII, não secciona o ângulo póstero-lateral do urotergito VII. Margem do urotergito VII apresentando uma fileira de pêlos com distribuição variável entre as espécies. Processo mediano bem desenvolvido, margem posterior inteira e com uma lígula membranosa. Membrana pouco desenvolvida, estreita e estendendo-se por toda margem posterior. Ápice do processo ultrapassando muito a margem da membrana (figs. 267, 295).

Pigóforo com um tufo de pêlos longos na superfície lateral,

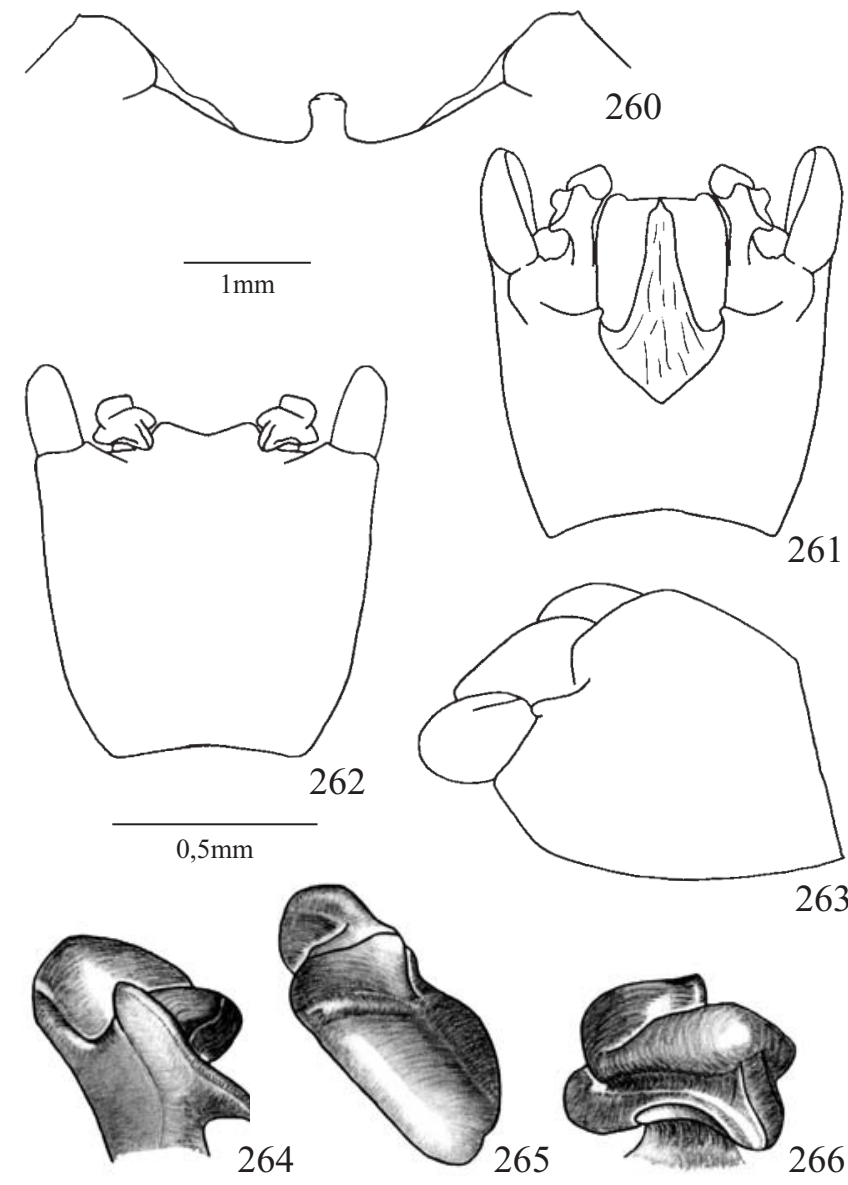

Figs. 260-266. Antiteuchus melanoleucus. 260, Processo mediano do tergito VII; 261-263, Pigóforo em vistas dorsal, ventral e lateral, respectivamente; 264-266, Parâmero em vistas dorsal, posterior e ventral, respectivamente.

junto à base do ângulo póstero-lateral. Processo látero-dorsal desenvolvido, recoberto por pêlos esparsos e atingindo a base do ângulo póstero-lateral do pigóforo, sem fundir-se a ele (figs. 192, 213). Bordo dorsal sem projeções laterais ao segmento X. Expansões do bordo dorsal, laterais ao segmento $\mathrm{X}$, pouco desenvolvidas e não avançando sobre o segmento X (figs. 190, 211). Escavação do bordo dorsal mais larga que profunda (figs. 190, 211). Diafragma com um grande processo membranoso arredondado. Folheto interno do bordo ventral projetado internamente sobre a taça genital onde forma um processo arredondado, saliente, plano, espesso e escuro processo superior do bordo ventral (psbv) - (figs. 190, 211). Superfície ventral com um tufo de pêlos longos junto a cada processo dos ângulos póstero-laterais do pigóforo, exceto $A$. sepulcralis. Ângulo póstero-lateral do pigóforo ogival, em vista lateral, reto, paralelo, menos de 1,5 vezes mais longo que largo, em vista lateral, e com o ápice intumescido (figs. 192, $211,213)$. Face interna do processo margeada por uma borda baixa, arredondada, com textura própria e apresentando uma fileira de pêlos longos. Processo implantado no plano longitudinal do pigóforo. 
Cabeça do parâmero perpendicular ao eixo longitudinal do pigóforo. Não ocorrem carenas sobre a margem do parâmero. Lobo ventral com formas diferentes, mas apresentando sempre uma projeção triangular ou espiniforme dirigida láteroventralmente (figs. 195, 201).

Segmento X recoberto por densa pubescência, exceto na base. Face posterior perpendicular ao plano longitudinal do segmento X, com exceção de $A$. tripterus e $A$. variegatus onde a face é quase perpendicular; sem carenas laterais, crista mediana ou área intumescida basal. Ductus seminis distalis tão ou pouco mais longo que o falo.

Comentários: Este grupo é facilmente reconhecido por possuir setas entre as sétulas que recobrem os artículos antenais II e III, exceto $A$. mixtus e $A$. radians; pela metapleura sem um grande calo junto à margem externa, com exceção de A. radians; pelo processo mediano do urotergito VII com uma lígula membranosa no ápice; pela margem do urotergito VII apresentando uma fileira de pêlos e uma membrana estreita; pelo ápice do processo ultrapassando muito a margem da membrana; pela escavação do bordo dorsal mais larga que profunda; pelo diafragma com um grande processo membranoso arredondado; pela presença do processo superior do bordo ventral esclerotizado e negro; pelo bordo ventral com um tufo de pêlos longos junto a cada processo dos ângulos póstero-laterais do pigóforo, exceto $A$. sepulcralis; pelo ângulo póstero-lateral do pigóforo ogival, em vista lateral, reto, paralelos e com o ápice intumescido; pela face interna do ângulo margeada por uma borda baixa, arredondada, com textura própria e apresentando uma fileira de pêlos longos; pelo lobo ventral do parâmero com formas diferentes, mas apresentando sempre uma projeção triangular ou espiniforme dirigida látero-ventralmente; pelo segmento $\mathrm{X}$ recoberto por densa pubescência, exceto na base.

\section{Chave de identificação para os machos das espécies do grupo \\ A. mixtus}

1. Corpo giboso. Segmentos antenais II e III recobertos apenas por sétulas, pêlos mais curtos que o diâmetro do segmento

Corpo achatado dorso-ventralmente. Segmentos antenais II e III apresentando setas, pêlos tão ou mais longos que o diâmetro do segmento, entre as sétulas

2(1). Superfície do corpo irregular, pontuação profunda. Machos totalmente escuros e fêmeas claras com manchas escuras sobre a superfície dorsal. Metapleura desprovida de um calo amarelo em seu ângulo ântero-lateral. Segmento X com a região láteroposterior apresentando uma pequena escavação A. mixtus

Superfície do corpo lisa, pontuação pouco profunda. Machos e fêmeas apresentando a mesma coloração e padrão de manchas sobre a superfície dorsal. Metapleura com um grande calo amarelo no ângulo ântero-lateral. Segmento X com a região láteroposterior levemente intumescida
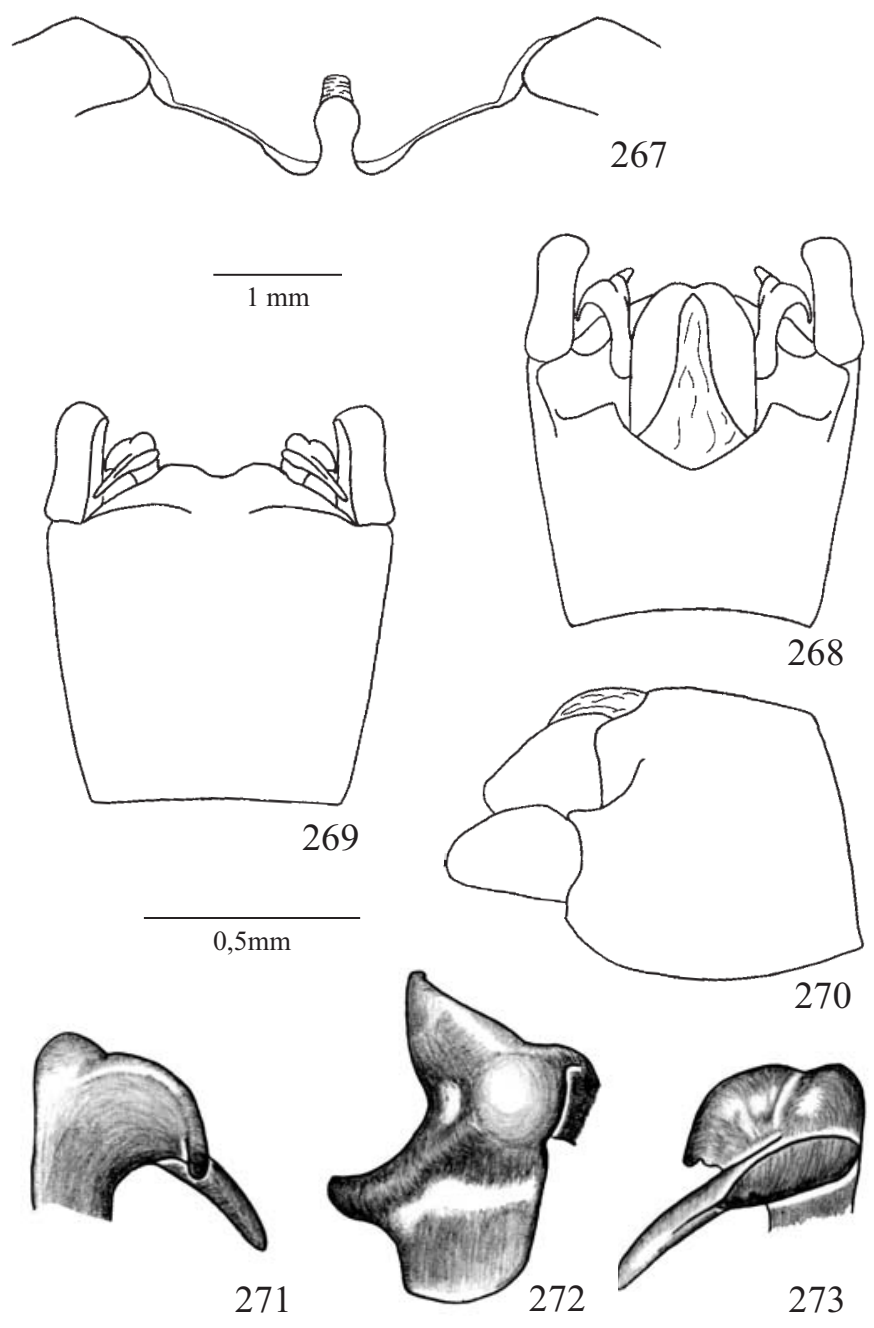

Figs. 267-273. Antiteuchus mixtus. 267, Processo mediano do tergito VII; 268-270, Pigóforo em vistas dorsal, ventral e lateral, respectivamente; 271-273, Parâmero em vistas dorsal, posterior e ventral, respectivamente.

3(1). Ápice do processo mediano do urotergito VII liso ...... 4 Ápice do processo mediano do urotergito VII enrugado

4(3). Segmento X globoso, face posterior muito inclinada, quase perpendicular em relação ao plano frontal do pigóforo (fig. 226) A. tripterus

Segmento X semicilíndrico, face posterior perpendicular em relação ao plano frontal do pigóforo (figs. 211, 218)

.5

5(4). Bordo ventral do pigóforo baixo e com a margem côncava. Base do processo superior do bordo ventral sem uma carena elevada. Ângulo póstero-lateral do pigóforo mais longo que a área esclerotizada do segmento X (figs. 190, 191, 218, 219) ....

Bordo ventral do pigóforo alto e com a margem posterior reta ou levemente convexa. Base do processo superior 
do bordo ventral elevado, em relação ao restante do bordo ventral, formando uma carena curta e recoberta por um tufo denso de pêlos longos. Ângulo pósterolateral do pigóforo mais curto que a região esclerotizada do segmento X (figs. 211,212) .......... 7

6(5). Processo mediano do urotergito VII curto e retangular (fig. 217). Superfície ventral do pigóforo com um tufo de pêlos longos junto ao ângulo póstero-lateral do pigóforo . A. fulvescens

Processo mediano do urotergito VII longo e expandido no ápice (fig. 189). Superfície ventral do pigóforo sem um tufo de pêlos junto ao ângulo póstero-lateral do pigóforo A. sepulcralis

7(5). Machos e fêmeas apresentam coloração dorsal clara, amarela ou castanha, com um padrão regular de manchas negras. Lobo ventral do parâmero estreito (figs. 208) . A. pictus

Machos negros e fêmeas negras ou claras com um padrão irregular de manchas castanho-escuras sobre a superfície dorsal. Lobo ventral do parâmero largo (figs. 201, 215)

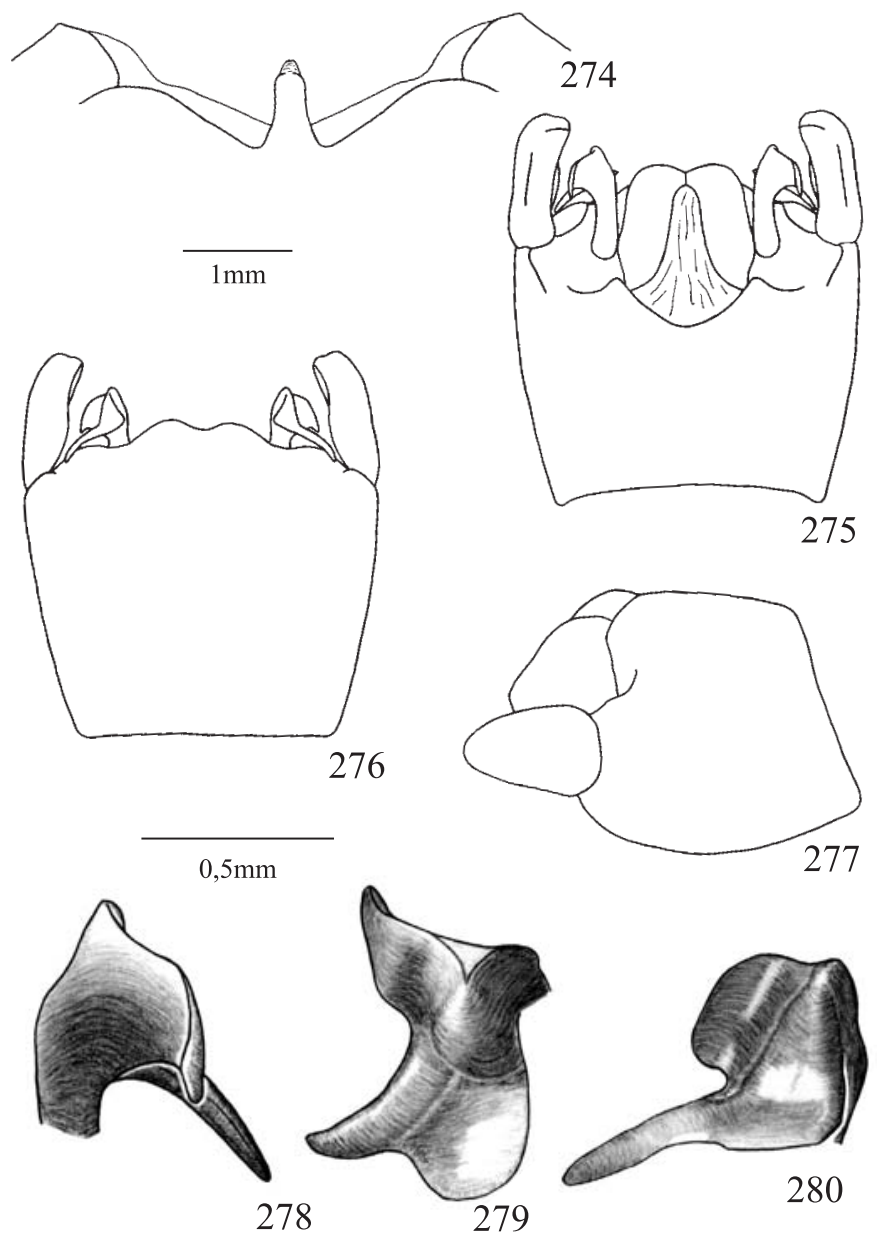

8(7). Corpo completamente negro. Ângulo póstero-lateral do pigóforo nitidamente mais curto que a área esclerotizada do segmento X. Lobo lateral interno do parâmero pequeno e muito inclinado lateralmente, lobo ventral não visível em vista dorsal (figs. 213, 214) A. melanicus sp. nov.

Coloração ventral amarela a castanha recoberto por manchas castanho-escuras. Ângulo póstero-lateral do pigóforo quase tão longo quanto a área esclerotizada do segmento X. Lobo lateral interno do parâmero amplo e pouco inclinado lateralmente, lobo ventral visível em vista dorsal (figs. 199, 200)

Figs. 274-280. Antiteuchus radians. 274, Processo mediano do tergito VII; 275-277, Pigóforo em vistas dorsal, ventral e lateral, respectivamente; 278-280, Parâmero em vistas dorsal, posterior e ventral, respectivamente.

A. nigricans

9(3). Pontuação dorsal distribuída em linhas sinuosas transversais recobertas por faixas e manchas castanhas. Presença de um tubérculo sobre a superfície ventral do pigóforo, junto à base de cada ângulo póstero-lateral do pigóforo (figs. 234, 248) ...

Pontuação dorsal agrupada em manchas ou faixas longitudinais castanhas, principalmente sobre o hemiélitro e escutelo. Superfície ventral do pigóforo sem nenhum tipo de processo sobre a superfície (figs. 290, 297)

10(9). Margem do urotergito VII com um par de projeções espessadas nas laterais. Margem dorsal do parâmero curvada internamente ou não. Lobo ventral do parâmero estreito e apresentando uma aba que se projeta-se sobre o lobo (figs. 251, 252)

12(11). Lobo lateral interno do parâmero longo e largo. Aba do lobo ventral estreita. Lobo ventral fortemente curvado (figs. 250-252) . A. costaricensis

Lobo lateral interno do parâmero curto e estreito. Aba do lobo ventral larga, cobrindo a extremidade do parâmero em vista posterior. Lobo ventral não tão curvado como acima (figs. 257-259) A. innocens 
13(9). Pontuação dorsal agrupada em manchas irregulares de coloração castanha à castanho-escura. Urotergito VII com pêlos distribuídos ao longo de toda margem e sem um par de projeções espessadas nas laterais. Ângulo póstero-lateral do pigóforo mais curto que a área esclerotizada do segmento X (figs. 260, 263) ......

A. melanoleucus

Pontuação dorsal agrupada em faixas longitudinais de coloração castanha. Urotergito VII com um par de projeções espessadas nas laterais que limitam a distribuição dos pêlos à região central. Ângulo póstero-lateral do pigóforo nitidamente mais longo que a área esclerotizada do segmento X (figs. 281, $284,288,291)$ .14

14(13). Processo mediano do urotergito VII levemente expandido no ápice. Segmento X com a região láteroposterior projetada posteriormente podendo formar um pequeno tubérculo (figs. 281, 282) ..... A. macraspis

Processo mediano do urotergito VII com os $2 / 3$ posteriores expandidos. Segmento X com tubérculos bem desenvolvidos (figs. 288, 289, 295, 296) ........ 15

15(14). Face posterior do segmento $X$ perpendicular a face dorsal. Lobo lateral interno do parâmero largo. Lobo ventral do parâmero com apenas um dos ângulos projetado (figs. 293-294) A. schuhi

Face posterior do segmento $\mathrm{X}$ quase perpendicular a face dorsal. Lobo lateral interno do parâmero estreito. Lobo ventral do pigóforo com ambos os ângulos desenvolvidos (figs. 300-301). A. variegatus

Antiteuchus sepulcralis (Fabricius, 1803)

(Figs. 189-195, 306)

Stoll, 1787, fig. 94 .

Edessa sepulcralis Fabricius, 1803: 152.

Antiteuchus luctuosus Stål, 1855: 182; Walker, 1867: vol. 1, 198 (lista). Antiteuchus sepulcralis; Stål, 1868: 19; Ruckes, 1961: 152.

Dinocoris (Mecistorhinus) sepulcralis; Stål, 1872: 8.

Dinocoris sepulcralis; Lethierry \& Severin, 1893: 86.

Mecistorhinus (Mecistorhinus) sepulcralis; Kirkaldy, 1909: 217.

Antiteuchus (Antiteuchus) sepulcralis; Ruckes, 1964: 63 (chave), 74,

76, figs. 32-33; Becker \& Grazia-Vieira, 1971: 21 (lista); Engleman

\& Rolston, 1983: 179 (chave); Rolston, 1993: 121-122

(determinação de lectótipo e paralectótipos).

Medidas ( $\mathrm{n}=20)$ : comprimento total- 9,5-11,6; largura total$5,9-7,1$

Corpo achatado dorso-ventralmente, coloração dorsal variando entre o amarelo com faixas longitudinais e manchas castanhas até totalmente negro com pequenas manchas amarelas dispersas sobre a superfície. Pontuação densa e distribuída em faixas transversais, sem formar agrupamentos irregulares; sobre o hemiélitro das fêmeas a pontuação concentra-se em faixas longitudinais.

Artículos antenais II e III apresentam setas entre as sétulas. Segmentos antenais I e II amarelos com manchas escuras.

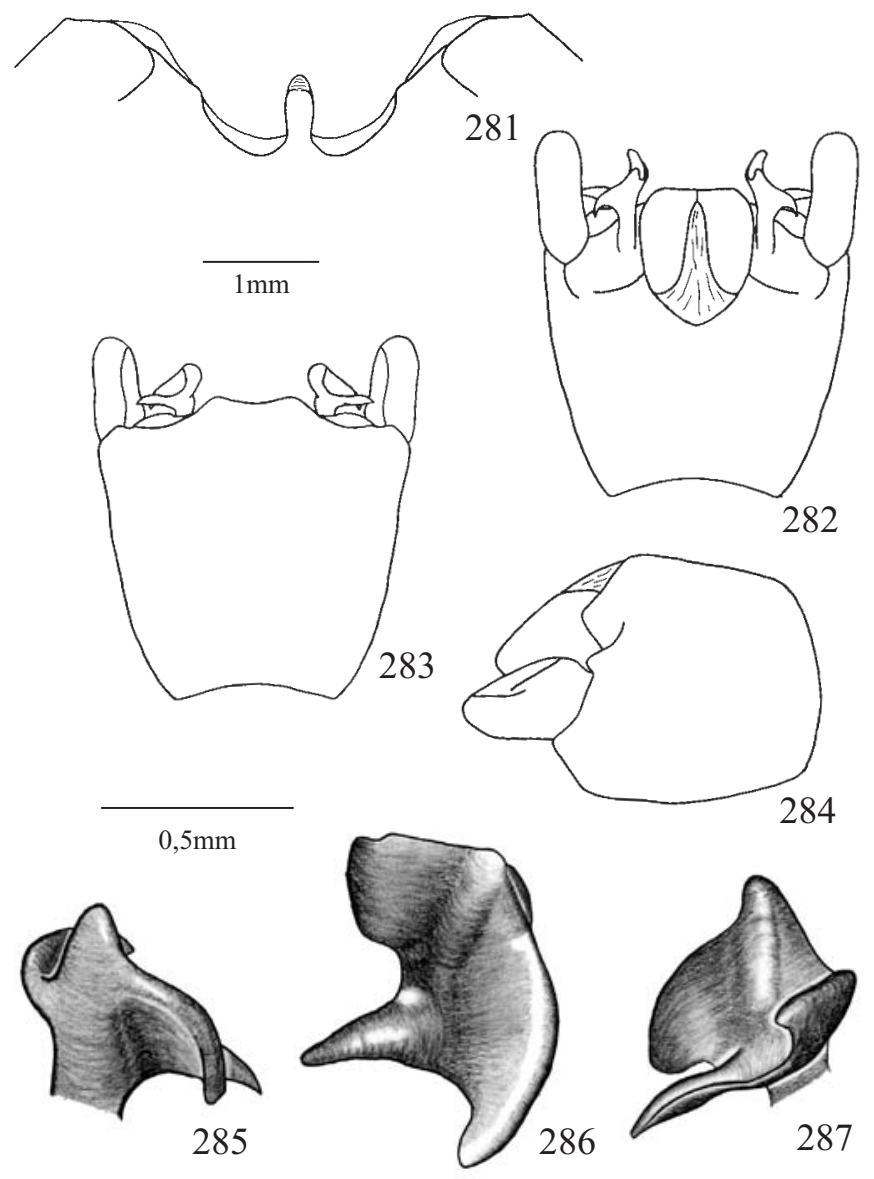

Figs. 281-287. Antiteuchus macraspis. 281, Processo mediano do tergito VII; 282-284, Pigóforo em vistas dorsal, ventral e lateral, respectivamente; 285-287, Parâmero em vistas dorsal, posterior e ventral, respectivamente.

Segmentos III e IV castanhos a negros. Segmento V amarelo com um anel basal negro. Segmentos em ordem crescente de comprimento: II; I; III, IV e V subiguais.

Rostro amarelo a castanho-escuro. Hemiélitro com ápice atingindo a metade posterior do conexivo VII. Escutelo com ápice arredondado atingindo a metade distal do urotergito VII. Ventralmente o tórax apresenta pontuação densa, castanha à negra. Área evaporatória castanha. Ruga ostiolar negra com o ápice amarelo. Mesopleura com ou sem um pequeno calo amarelo-pálido. Metapleura sem um grande calo junto à margem externa. Coxas, trocânteres, tíbias e tarsos amarelos a amareloescuros e imaculados. Fêmures amarelos a castanho-escuros e recobertos por manchas castanhas que aumentam de densidade em direção ao ápice. Tíbias com alguns pêlos mais longos que o diâmetro do segmento. Conexivo variando entre amarelo com pontuação castanha até uniformemente castanhoescura. Coloração dorsal do abdome amarela à castanho-escura. Face ventral do abdome amarela a castanho. Pode ou não ocorrer uma área amarela interna a cada espiráculo. Margem lateral com os ângulos póstero-laterais negros. Urotergito VII com um par de projeções arredondadas e espessadas junto à projeção mediana; pêlos distribuídos por toda margem. Parte 
livre do processo mediano longa, estreita, plana e curvada póstero-ventralmente; ápice expandido e liso, margem posterior com uma pequena lígula membranosa. Membrana estreita na região mediana, alargando-se a partir da projeção espessada (fig. 189).

Pigóforo amarelo-escuro com a superfície ventral castanhoescuro entremeado com manchas amarelas. Escavação do bordo dorsal cerca de duas vezes mais larga que profunda (fig. 190). Projeções laterais ao segmento X arredondadas. Processo superior do bordo ventral côncavo e negro. Em vista posterior, é possível ver uma pequena concavidade na margem do bordo, onde encaixa-se o parâmero. Região mediana baixa, plana e inclinada posteriormente, margem superior côncava e tão larga quanto a extremidade do segmento X (fig. 191). Superfície ventral sem um tufo denso de pêlos longos. Abaixo da região mediana ocorre uma área côncava sem elevação central e recoberta por pêlos esparsos. Ângulo póstero-lateral do pigóforo castanho-escuro e quase tão largo quanto longo em vista lateral (fig. 192). Ângulo tão longo quanto a área esclerotizada do segmento X. Face interna acentuadamente côncava devido ao grande desenvolvimento da borda que circunda a margem interna. Face dorso-lateral plana. Face ventral convexa podendo apresentar manchas amarelas.

Cabeça do parâmero (figs. 193-195) composta por 4 lobos. Dorsal fundido com o lateral externo, amplo e inclinado posteriormente, margem superior espessa, exceto na região anterior onde existe uma pequena área achatada e projetada anteriormente; carena dorsal inconspícua. Lobo lateral interno amplo, ovalado transversalmente, envolvendo parcialmente a margem do lobo dorsal, levemente convexo na face dorsal e pouco inclinado lateralmente; ventralmente une-se ao lobo ventral por uma parede delgada e côncava. Lobo lateral externo amplo, afilado em direção ao ápice, levemente convexo e dirigido látero-anteriormente. Lobo ventral pequeno, retangular e curvado posteriormente, ângulo póstero-lateral interno com uma pequena projeção triangular curvada ventralmente. Projeção ventral do lobo lateral interno quase tocando o lobo ventral, isto se deve à pequena curvatura da parede associado a inclinação dorsal do lobo ventral.

Segmento X semicilíndrico; região látero-posterior muito intumescida (fig. 190). Tubérculos ausentes. Face posterior levemente convexa transversalmente. Área membranosa dorsal atingindo o final da face dorsal.

Lectótipo macho. "America Meridionalis, Schimidt, Mus Schestadt, Edessa sepulcralis Fabricius", "Lectotype Edessa sepulcralis Fabricius" (ZMUC). Examinado.

Distribuição: Trinidad e Tobago, Trinidad: Arima. VEZUELA, Tachira: Pregonero. Suriname, Brokopondo: Paramaribo, Brokopondo. Brasil, Amazonas: Manaus, Itacoatiara; Pará: Belém, Óbidos, Tomé-Açú, Castanhal; Rondônia: Ouro Preto d'Oeste, Cacoal; Maranhão: São Luis, Bacabal; Piauí: Teresina; Ceará: Fortaleza; Paraíba: João Pessoa; Pernambuco: Recife; Bahia: Curaça, Utinga, Salvador; Rio de Janeiro: Campos, Rio de Janeiro, Seropédica. Bolívia, Cochabamba: Rio Chaparé; Beni: Rurrenabaque.

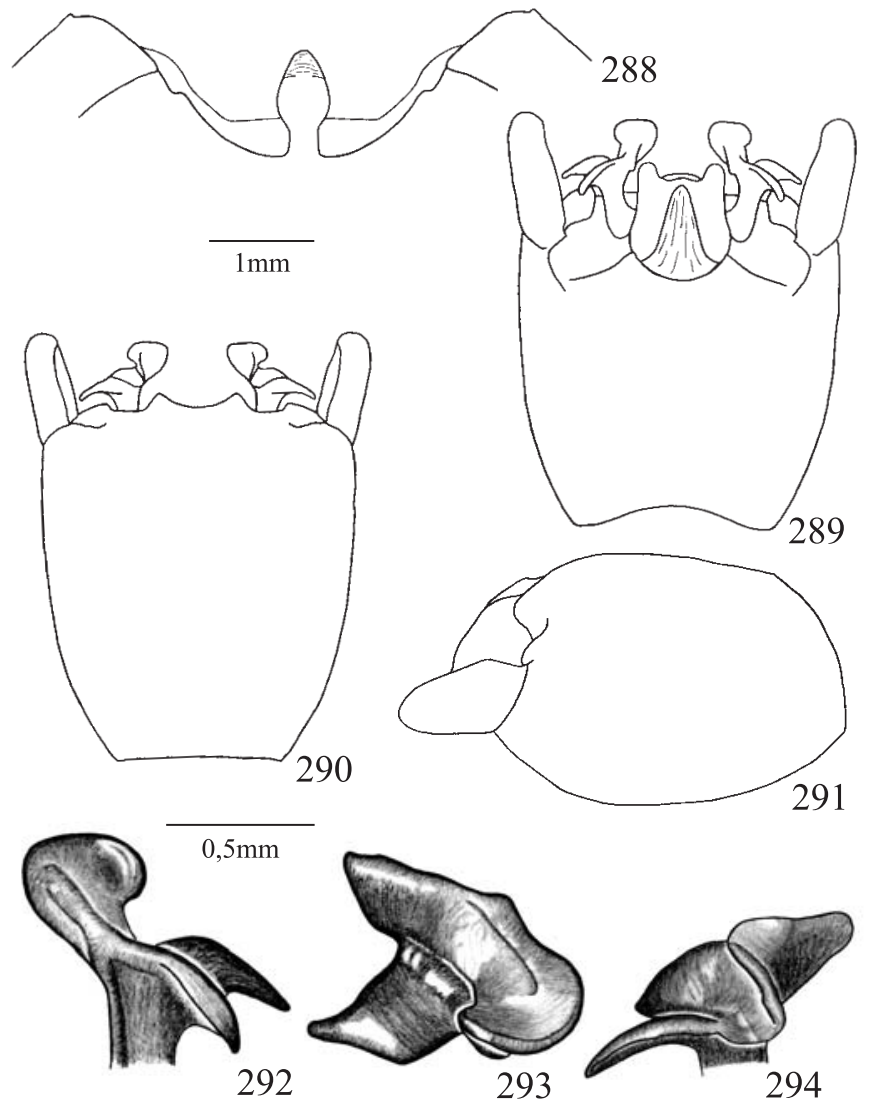

Figs. 288-294. Antiteuchus schuhi. 288, Processo mediano do tergito VII; 289-291, Pigóforo em vistas dorsal, ventral e lateral, respectivamente; 292-294, Parâmero em vistas dorsal, posterior e ventral, respectivamente.

Comentários: Os exemplares analisados pertencem às coleções do AMNH, BMNH, CASC, INPA, FIOC, MPEG, MZSP, MNHN, MNRJ, RMNH, UFRG e NMNH. As fêmeas de A. sepulcralis são facilmente reconhecidas por possuírem uma coloração dorsal amarelo-alaranjada com faixas longitudinais castanhas. Esta espécie pode ser reconhecida pela ausência de um tufo denso de pêlos longos em cada lateral da superfície ventral, junto aos ângulos póstero-laterais do pigóforo; pela face interna dos processos dos ângulos póstero-laterais do pigóforo acentuadamente côncava devido ao grande desenvolvimento da borda que circunda a margem interna; pelo lobo lateral interno amplo, ovalado transversalmente; pelo lobo ventral pequeno, retangular e curvado posteriormente, ângulo póstero-lateral interno pouco projetado. A. sepulcralis compartilha com $A$. nigricans, $A$. pictus e $A$. melanicus a região látero-posterior do segmento X muito intumescida e esférica, sem a formação de um pequeno tubérculo. A. sepulcralis compartilha com $A$. nigricans, A. pictus, A. melanicus, $A$. fulvescens, A. tripterus, A. maculosus, A panamensis, $A$. costaricensis, $A$. innocens e $A$. melanoleucus a presença de pêlos distribuídos por toda margem posterior do urotergito VII. Esta espécie apresenta em comum com nigricans, A. pictus, A. melanicus, A. maculosus e A. melanoleucus a ausência de 
um par de projeções arredondadas e espessadas na margem do urotergito VII. A. sepulcralis, A. fulvescens e A. tripterus apresentam em comum o bordo ventral baixo, plano, inclinado posteriormente e com a margem superior côncava.

Antiteuchus nigricans Ruckes, 1964

(Figs. 196-202, 306)

Antiteuchus (Antiteuchus) nigricans Ruckes, 1964: 63 (chave), 71-72, figs. 25-26; Engleman \& Rolston, 1983: 179 (chave).

Medidas ( $\mathrm{n}=20)$ : comprimento total- 10,8-12,0; largura total7,1-7,7.

Corpo achatado dorso-ventralmente, coloração dorsal variando entre amarelo com manchas castanhas até negro com pequenas manchas amarelas dispersas sobre a superfície dorsal. Pontuação densa e distribuída uniformemente.

Artículos antenais II e III apresentam setas entre as sétulas. Segmentos antenais I e II amarelos com manchas escuras. Segmentos III e IV negros. Segmento V amarelo com um anel basal negro. Segmentos em ordem crescente de comprimento: II; I; III e IV subiguais; V.

Rostro amarelo a negro. Hemiélitro com ápice atingindo a metade posterior do conexivo VII. Escutelo com ápice arredondado atingindo a metade distal do urotergito VII. Ventralmente o tórax apresenta-se amarelo com pontuação densa castanha. Área evaporatória castanha. Ruga ostiolar castanha com o ápice amarelo. Mesopleura com ou sem um pequeno calo amarelo-pálido. Metapleura sem um grande calo junto à margem externa. Coxas e trocânteres amarelo-escuros a castanhos e imaculados. Fêmures amarelos recobertos por manchas castanhas que aumentam de densidade em direção ao ápice. Tíbias amarelas com grandes manchas castanhoescuras a negras ou totalmente negras; alguns pêlos são mais longos que o diâmetro do segmento. Tarsos amarelos a negros. Conexivo apresentando áreas intersegmentares escuras; pontuação densa e castanha. Coloração dorsal do abdome castanho-escura. Face ventral do abdome amarela à castanha. Pode ou não ocorrer uma área amarela interna a cada espiráculo. Margem lateral com uma mancha amarela à castanha em cada segmento. Urotergito VII sem um par de projeções arredondadas e espessadas; pêlos distribuídos por toda margem. Parte livre do processo mediano curta, larga, plana e curvada póstero-ventralmente; ápice expandido e liso, margem posterior com uma pequena lígula membranosa. Membrana estreita na região mediana, alargando-se apenas no 1/4 lateral (fig. 196).

Pigóforo amarelo-escuro com a região posterior negra. Escavação do bordo dorsal cerca de duas vezes mais larga que profunda. Projeções laterais ao segmento X arredondadas (fig. 197). Processo superior do bordo ventral grande, arredondado, plano e negro. A base do processo superior está elevada, em relação ao restante do bordo ventral, formando uma carena (cabv) curta, recoberta por um tufo denso de pêlos longos (fig. 198). Em vista posterior, é possível ver uma grande concavidade na margem, onde encaixa-se o parâmero. Região

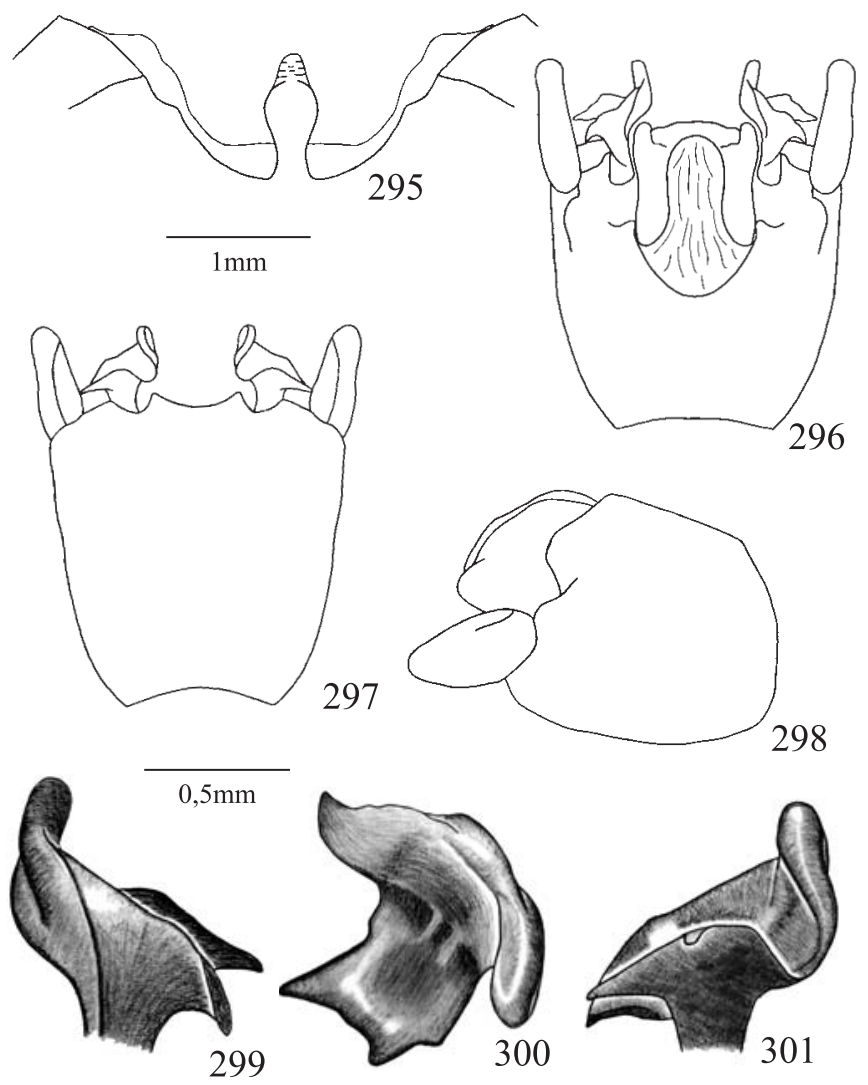

Figs. 295-301. Antiteuchus variegatus. 295, Processo mediano do tergito VII; 296-298, Pigóforo em vistas dorsal, ventral e lateral, respectivamente; 299-301, Parâmero em vistas dorsal, posterior e ventral, respectivamente.

mediana alta, levemente convexa transversalmente e inclinada posteriormente, margem superior reta ou levemente biconvexa e mais estreita que a extremidade do segmento X. Abaixo da região mediana ocorre uma área côncava com um par de áreas levemente túmidas laterais à linha mediana, sem elevação central e recoberta por pêlos esparsos. Ângulo póstero-lateral do pigóforo castanho-escuro a negro e pouco mais largo que longo em vista lateral (fig. 199). Ângulo mais curto que a área esclerotizada do segmento X. Face interna levemente côncava. Face dorso-lateral levemente côncava, apresentando uma elevação estreita e curta em continuação ao processo láterodorsal. Face ventral escavada junto à base e levemente convexa na metade apical.

Cabeça do parâmero (fig. 200-202) composta por 4 lobos. Dorsal fundido ao lateral externo, amplo, largo, alto e fortemente inclinado posteriormente, margem dorsal com uma grande área achatada e rebatida lateralmente; carena dorsal inconspícua. Lobo lateral interno pequeno, arredondado, plano na face dorsal, pouco inclinado lateralmente e dirigido pósterolateralmente, margem posterior espessa e fundida com a margem do lobo dorsal; ventralmente une-se ao lobo ventral por uma parede delgada e côncava. Lobo lateral externo pouco desenvolvido, formado por uma pequena convexidade da 
parede visível em vista posterior. Lobo ventral sub-retangular, amplo, largo, convexo e dirigido póstero-ventralmente, margem apresentando uma pequena projeção espiniforme no ângulo póstero-lateral externo dirigida látero-anteriormente.

Segmento X semicilíndrico; região látero-posterior muito intumescida (fig. 197). Tubérculos ausentes. Face posterior levemente convexa. Área membranosa dorsal atingindo o final da face dorsal.

Holótipo macho. "Palmira Valley, Colombia; May 5, 1948" (AMNH). Três parátipos com os mesmos dados do holótipo foram examinados.

Distribuição: Colômbia, Antioquia: Medellin; Huila: Gigante, Gallego; Valle del Cauca: Palmira Valley. Equador, Napo: Coca.

Comentários: Os exemplares analisados pertencem às coleções do AMNH, BMNH, MNHN e NMNH. Esta espécie pode ser diferenciada das outras do grupo pelo lobo dorsal do parâmero fortemente inclinado póstero-ventralmente, margem dorsal com uma grande área achatada e rebatida lateralmente; e pelo lobo lateral interno pouco inclinado lateralmente. $A$. nigricans compartilha com $A$. pictus e $A$. melanicus a presença de uma carena recoberta por pêlos sobre o bordo ventral do pigóforo; bordo ventral do pigóforo alto, levemente convexo transversalmente e inclinado posteriormente; e o ângulo póstero-lateral do pigóforo mais largo que longo, em vista lateral. Estas três espécies compartilham com A. melanoleucus o ângulo póstero-lateral do pigóforo mais curto que a área esclerotizada do segmento X. A. nigricans compartilha com $A$. melanicus o lobo ventral do parâmero largo.

Antiteuchus pictus Ruckes, 1964

(Figs. 203-209, 306)

Antiteuchus (Antiteuchus) pictus Ruckes, 1964: 64 (chave), 79-80, fig 39; Engleman \& Rolston, 1983: 179 (chave).

Medidas $(n=3)$ : comprimento total- 10,7-12,2; largura total$6,9-7,5$

Corpo achatado dorso-ventralmente, coloração dorsal amarela à amarelo-alaranjada. Esta espécie possui um padrão de coloração característico. Pronoto negro com a linha mediana e mais duas manchas posteriores amarelas a amareloalaranjadas. Hemiélitro com uma grande mancha escura na metade posterior. Escutelo com dois ou três pares de manchas escuras. As manchas do hemiélitro e as posteriores do escutelo, quando presentes, estão alinhadas formando uma faixa incompleta. O macho é pouco mais escuro que as fêmeas. Pontuação densa e distribuída uniformemente.

Artículos antenais II e III apresentam setas entre as sétulas. Segmentos antenais I e II amarelos. Segmento III amarelo com um anel negro próximo ao ápice. Segmento IV negro com dois anéis estreitos amarelos a alaranjados, um na base e outro no ápice. Segmento V amarelo. Segmentos em ordem crescente de comprimento: II; I; III e IV subiguais; V.

Rostro amarelo. Hemiélitro com ápice atingindo a metade

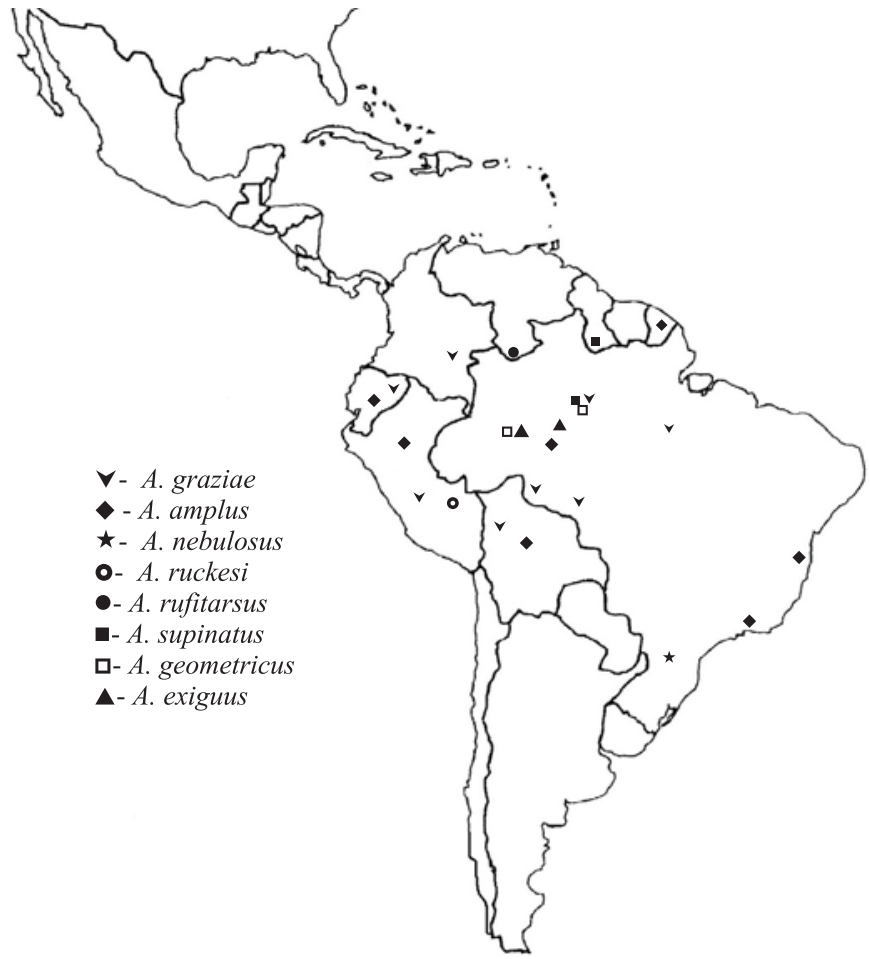

Fig. 302. Mapa de distribuição dos grupos de espécies $A$. supinatus e $A$. amplus.

posterior do conexivo VII. Escutelo com ápice arredondado atingindo a metade distal do urotergito VII. Ventralmente o tórax apresenta-se amarelo com pontuação densa, castanha à negra; metade lateral totalmente negra ou castanho-escura. Área evaporatória negra. Ruga ostiolar amarela. Mesopleura sem um pequeno calo amarelo-pálido. Metapleura sem um grande calo junto à margem externa. Coxas e trocânteres amarelos e imaculados. Fêmures amarelos a alaranjados com ou sem manchas castanho-claras. Tíbias amarelas a alaranjadas; alguns pêlos de comprimento maior que o diâmetro do segmento. Tarsos amarelos a alaranjados. Conexivo apresentando áreas intersegmentares negras alternadas com áreas amarelas; pontuação densa e castanha. Coloração dorsal do abdome castanha. Face ventral do abdome amarelo-escura na região mediana, escurecendo para as laterais. Margem lateral com ou sem uma pequena mancha amarela em cada segmento. Não ocorre uma área amarela interna a cada espiráculo. Urotergito VII sem um par de projeções arredondadas e espessadas; pêlos distribuídos por toda margem. Parte livre do processo mediano curta, larga, plana e curvada pósteroventralmente; ápice levemente expandido e liso, margem posterior com uma pequena lígula membranosa. Membrana estreita na região mediana, alargando-se apenas no 1/4 lateral (fig. 203).

Pigóforo amarelo-escuro com a região posterior escura. Escavação do bordo dorsal cerca de duas vezes mais larga que profunda (fig. 204). Projeções laterais ao segmento X arredondadas. Superfície ventral castanho-escuro com muitas 
manchas amarelas. Processo superior do bordo ventral grande, arredondado, plano e negro. A base do processo superior está elevada, em relação ao restante do bordo ventral, formando uma carena curta, recoberta por um tufo denso de pêlos longos. Em vista posterior, é possível ver uma grande concavidade na margem, onde encaixa-se o parâmero. Região mediana alta, plana e inclinada posteriormente, margem superior reta e mais estreita que a extremidade do segmento X (fig. 205). Abaixo da região mediana ocorre uma área côncava com um par de áreas levemente túmidas laterais à linha mediana, sem elevação central e recoberta por pêlos esparsos. Ângulo póstero-lateral do pigóforo castanho-escuro a negro e pouco mais largo que longo (fig. 206). Ângulo mais curto que a área esclerotizada do segmento X. Face interna amarela, levemente côncava. Face dorso-lateral plana, sem uma elevação estreita e curta na base e amarela com uma grande mancha castanha. Face ventral pouco escavada junto à base, levemente convexa na metade apical e negra.

Cabeça do parâmero (figs. 207-209) composta por 4 lobos. Dorsal fundido ao lateral externo, amplo, baixo, estreito e inclinado posteriormente, margem dorsal com uma pequena área achatada e rebatida lateralmente; carena dorsal inconspícua. Lobo lateral interno pequeno, arredondado, levemente côncavo na face dorsal, inclinado lateralmente e dirigido póstero-lateralmente, margem posterior espessa e perfeitamente fundida a margem do lobo dorsal; ventralmente une-se ao lobo ventral por uma parede delgada e côncava. Lobo lateral externo pouco desenvolvido, formado apenas por uma pequena convexidade da parede, visível em vista posterior. Lobo ventral sub-retangular, amplo, convexo, estreito e dirigido póstero-ventralmente, margem apresentando uma pequena projeção espiniforme no ângulo póstero-lateral externo dirigida látero-anteriormente.

Segmento X semicilíndrico; região látero-posterior muito intumescida (fig. 204). Tubérculos ausentes. Face posterior levemente convexa. Área membranosa dorsal atingindo o início da face posterior.

Holótipo fêmea. "Yarimaguas, Peru, 1866, Sallé col." (MNHN). Examinado.

Distribuição: Equador, Napo: Coca, Coyujo. Perú, Yarimaguas; Madre de Dios: New Pekitse (11 $\left.{ }^{\circ} 56^{\prime} \mathrm{S} 71^{\circ} 14^{\prime} \mathrm{W}\right)$.

Comentários: $\mathrm{O}$ macho desta espécie era desconhecido até este trabalho. Os exemplares analisados pertencem às coleções do AMNH, BMNH e Coleção particular de Eduardo Casini (Uruguai). Esta espécie é facilmente reconhecida pelo padrão de coloração dorsal. As fêmeas são amarelas e os machos amarelo-alaranjados, ambos os sexos possuem o pronoto e algumas manchas sobre o escutelo e hemiélitro negras. Lobo lateral interno do parâmero alongado, levemente côncavo na face dorsal e inclinado lateralmente. Lobo ventral do parâmero alongado. A. pictus compartilha com A. melanicus a margem do lobo dorsal do parâmero com uma pequena área achatada e rebatida lateralmente.

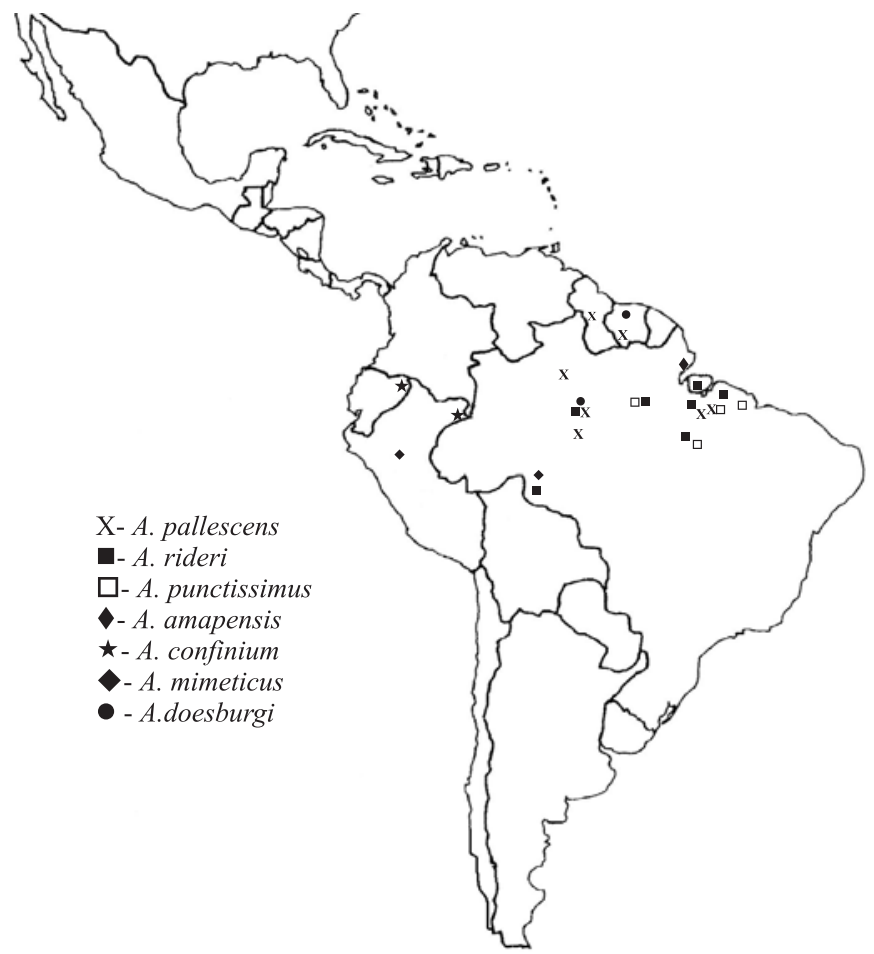

Fig. 303. Mapa de distribuição de parte das espécies do grupo $A$. peruensis: A. pallescens, A. rideri, A. punctissimus, A. amapensis, A. confinium, A. mimeticus e A. doesburgi.

\section{Antiteuchus melanicus sp. nov.}

(Figs. 210-216, 306)

Etimologia. Referência a coloração negra e uniforme de machos e fêmeas.

Medidas ( $\mathrm{n}=3)$ : comprimento total- 10,5-11,5; largura total$6,9-7,1$.

Corpo achatado dorso-ventralmente, coloração geral negra em ambos os sexos. Pontuação densa e distribuída uniformemente.

Artículos antenais II e III apresentam setas entre as sétulas. Segmentos antenais I e II castanho-escuros. Segmento III negro. Segmento IV negro com um anel amarelo na base. Segmento V negro com um anel amarelo no ápice. Segmentos em ordem crescente de comprimento: II; I; III; IV; V.

Disco pronotal, escutelo e margem do hemiélitro com pequenas manchas amarelas dispersas sobre a superfície. Hemiélitro com ápice atingindo a metade posterior do conexivo VII. Escutelo com ápice arredondado atingindo a metade distal do urotergito VII. Ventralmente o tórax apresenta-se totalmente negro ou com algumas manchas amarelas na região ventral. Coxas e trocânteres castanhos e imaculados. Fêmures amareloescuros a castanhos, recobertos por manchas castanhoescuras a negras que aumentam de densidade em direção ao ápice, região apical com uma mancha vermelha. Tíbias negras com algumas manchas amarelas; alguns pêlos são mais longos que o diâmetro do segmento. Tarsos negros. Conexivo negro com pontuação densa. Coloração dorsal e ventral do abdome 
negra. Urotergito VII sem um par de projeções arredondadas e espessadas; pêlos distribuídos por toda margem. Parte livre do processo mediano curta, larga, plana e curvada pósteroventralmente; ápice levemente expandido e liso, margem posterior com uma pequena lígula membranosa. Membrana estreita na região mediana, alargando-se apenas no 1/4 lateral (fig. 210).

Pigóforo amarelo-escuro com a região posterior castanhoescura. Escavação do bordo dorsal cerca de duas vezes mais larga que profunda (fíg. 211). Projeções laterais ao segmento $\mathrm{X}$ arredondadas. Processo superior do bordo ventral pequeno, arredondado, plano e negro. Em vista posterior, é possível ver uma grande concavidade na margem, onde encaixa-se o parâmero. Região mediana alta, levemente convexa transversalmente e inclinada posteriormente, margem superior reta ou levemente biconvexa e mais estreita que a extremidade do segmento X (fig. 212). A base do processo superior está elevada, em relação ao restante do bordo ventral, formando uma carena curta, recoberta por um tufo denso de pêlos longos. Abaixo da região mediana ocorre uma área levemente côncava com uma escavação central e recoberta por pêlos esparsos. Ângulo póstero-lateral do pigóforo castanho-escuro e pouco mais largo que longo em vista lateral (fig. 213). Ângulo mais curto que a área esclerotizada do segmento X. Face interna levemente côncava. Face dorso-lateral levemente côncava, apresentando uma elevação estreita e curta em continuação ao processo látero-dorsal. Face ventral escavada junto à base e levemente convexa na metade apical.

Cabeça do parâmero (figs. 214-216) composta por 4 lobos. Dorsal fundido ao lateral externo, amplo, baixo e inclinado posteriormente, margem dorsal espessada, exceto por uma pequena área achatada e rebatida lateralmente; carena dorsal inconspícua. Lobo lateral interno pequeno, ovalado, levemente côncavo na superfície dorsal, muito inclinado lateralmente e dirigido póstero-lateralmente, margem posterior espessa e perfeitamente fundida a margem do lobo dorsal; ventralmente une-se ao lobo ventral por uma parede delgada e côncava. Lobo lateral externo grande e triangular. Lobo ventral subretangular, amplo, largo, dirigido póstero-ventralmente e projetado posteriormente encobrindo parte da parede que o une ao lobo lateral interno, margem apresentando uma pequena projeção espiniforme no ângulo póstero-lateral externo dirigida látero-anteriormente.

Segmento X semicilíndrico; região látero-posterior muito intumescida. Tubérculos ausentes (fig. 211). Face posterior levemente convexa. Área membranosa dorsal atingindo o final da face dorsal.

Holótipo macho: PERÚ, Huánuco: Tingo Maria e Zungaro, IVIX-1991, S. Soria col., sobre Cacau (MCNZ). Parátipos: PERÚ, Huánuco: Tingo Maria e Zungaro, IV-IX-1991, S. Soria col., sobre Cacau, 1 macho (UFRG) e 1 fềmea (MCNZ).

Distribuição: Perú. Huánuco: Tingo Maria.

Comentários: Os exemplares analisados pertenciam à coleção da UFRG. Esta espécie pode ser facilmente reconhecida pela coloração negra do corpo, não só na superfície dorsal

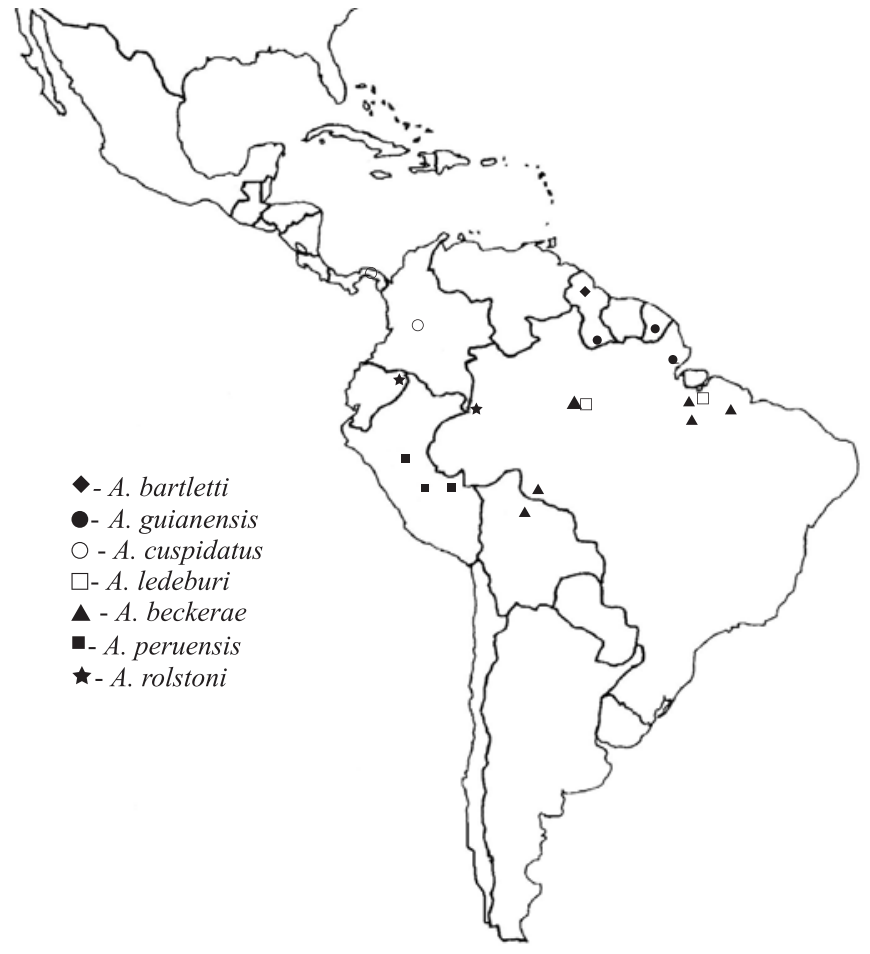

Fig. 304. Mapa de distribuição de parte das espécies do grupo A. peruensis: A. bartletti, A. guianensis, A. cuspidatus, A. ledeburi, A. beckerae, A. peruensis e $A$. rolstoni.

como em outras espécies. Lobo lateral interno do parâmero pequeno, menor que o de A. nigricans e A. pictus, ovalado, levemente côncavo na superfície dorsal e muito inclinado lateralmente. Lobo ventral projetado posteriormente encobrindo parte da parede que o une ao lobo lateral interno.

Antiteuchus fulvescens Ruckes, 1964

(Figs. 217-223, 307)

Antiteuchus (Antiteuchus) fulvescens Ruckes, 1964: 63 (chave), 7374, figs. 29-31. Engleman \& Rolston, 1983: 179 (chave).

Medidas do holótipo: comprimento total- 10,0; largura total5,6 .

Corpo achatado dorso-ventralmente, coloração dorsal castanho-clara. Pontuação densa e castanho-clara distribuída em linhas sinuosas transversais, principalmente sobre escutelo e pronoto, e não formando agrupamentos irregulares.

Artículos antenais II e III apresentam setas entre as sétulas. Segmentos antenais I-III castanho-claros. Segmentos em ordem crescente de comprimento: II; I; III. Segmentos IV-V desconhecidos.

Rostro castanho-claro. Hemiélitro com ápice atingindo a metade posterior do conexivo VII. Escutelo com ápice arredondado atingindo a metade distal do urotergito VII. Ventralmente o tórax apresenta-se amarelo-escuro com pontuação densa e castanha. Área evaporatória castanha. Ruga 
ostiolar amarelo-pálida. Mesopleura sem um pequeno calo amarelo-pálido. Metapleura sem um grande calo junto à margem externa. Coxas e trocânteres amarelos e imaculados. Fêmures, tíbias e tarsos castanho-claros. Tíbias com algumas manchas negras e alguns pêlos mais longos que o diâmetro do segmento. Conexivo amarelo-escuro com pontuação densa castanhoclara. Coloração dorsal do abdome castanho-clara. Face ventral do abdome amarelo-escura; junto a margem lateral ocorre uma faixa longitudinal onde as manchas são mais claras; existe ainda outra faixa, que engloba os espiráculos, onde as manchas são castanho-escuras. Cada espiráculo é quase totalmente circundado por uma linha amarela. Margem lateral sem manchas e com ângulos ântero e póstero-laterais de cada segmento negros. Urotergito VII sem um par de projeções arredondadas e espessadas; pêlos distribuídos ao longo de toda margem. Parte livre do processo mediano retangular, curta, larga, plana e curvada póstero-ventralmente; ápice não enrugado, margem posterior com uma grande lígula membranosa. Membrana alargando-se da região mediana para as laterais (fig. 217).

Pigóforo bastante mutilado. Coloração geral amareloescuro. Escavação do bordo cerca de duas vezes mais larga que profunda (fig. 218). Projeções laterais ao segmento $\mathrm{X}$ arredondadas. Processo superior do bordo ventral com a margem curvada e castanho. Em vista posterior, é possível ver uma grande concavidade na margem, onde encaixa-se o parâmero. Região mediana estreita, plana e inclinada posteriormente, margem superior côncava; não foi possível estabelecer a relação de largura entre a margem superior e a extremidade do segmento $\mathrm{X}$, devido ao deslocamento deste (fig. 219). Não foi possível estabelecer a presença dos pêlos na lateral do bordo, devido à mutilação. Não ocorrem processos sobre a superfície ventral. Abaixo da região mediana existe uma escavação mediana profunda. Ângulo póstero-lateral do pigóforo quase tão largo quanto longo em vista lateral (fig. 220). Ângulo tão ou pouco mais longo que a área esclerotizada do segmento X. Face interna levemente côncava e com a margem castanho-clara. Face dorso-lateral plana ou levemente côncava, ápice castanho-claro. Face ventral plana, levemente escavada junto a base e castanho-clara.

Cabeça do parâmero (figs. 221-223) composta por 4 lobos. Dorsal fundido com o lateral externo, amplo, alto e fortemente inclinado posteriormente, margem dorsal levemente achatada e rebatida lateralmente; carena dorsal inconspícua. Lobo lateral interno longo, estreito, ovalado, envolvendo parcialmente a margem do lobo dorsal, plano na superfície dorsal, pouco inclinado lateralmente e dirigido póstero-ventralmente; ventralmente une-se ao lobo ventral por uma parede delgada e côncava. Lobo lateral externo sub-retangular, curto, largo e convexo. Lobo ventral triangular, fortemente convexo e com ápice projetado látero-ventralmente.

Segmento X semicilíndrico; região látero-posterior muito intumescida e levemente projetada posteriormente sem formar pequenos tubérculos; face posterior plana (fig. 218). Área membranosa dorsal atingindo o início da face posterior.

Holótipo macho. "Rio Santiago, Peru, September 5, 1930, H. Bassler coll.” (AMNH). Examinado.

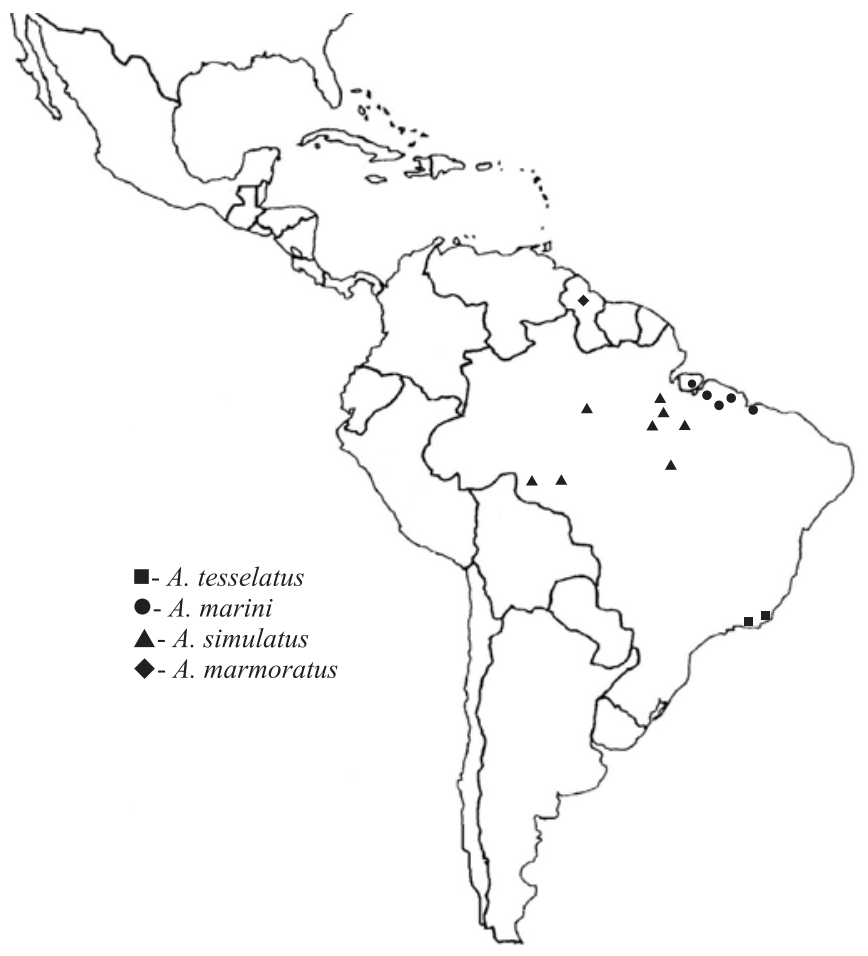

Fig. 305. Mapa de distribuição das espécies dos grupos A. tesselatus e $A$. marmoratus.

Distribuição: Perú, Amazonas: Rio Santiago.

Comentários: Espécie conhecida apenas pelo holótipo. O pigóforo do holótipo está bastante danificado devido à remoção do parâmero esquerdo e ao deslocamento lateral do segmento X. Esta espécie é facilmente reconhecida pelo seu pequeno tamanho; pela coloração dorsal castanho-clara e sem manchas escuras; pela parte livre do processo mediano do urotergito VII retangular, curta e larga, margem posterior com uma grande lígula membranosa; pelo lobo dorsal do parâmero fortemente inclinado posteriormente, margem dorsal levemente achatada e rebatida lateralmente; pelo lobo lateral interno alongado, ovalado, plano na superfície dorsal, pouco inclinado lateralmente e levemente curvado; pelo lobo ventral triangular, fortemente convexo e com ápice projetado látero-ventralmente; pelo segmento $\mathrm{X}$ com a região látero-posterior muito intumescida e levemente projetada posteriormente sem formar pequenos tubérculos. Esta espécie se diferencia de $A$. tripterus pela forma alongada do lobo lateral do parâmero e pela forma do segmento X. A. fulvescens, A. tripterus, A. maculosus, $A$. panamensis, $A$. costaricensis, $A$. innocens, $A$. melanoleucus, $A$. mixtus, $A$. radians e $A$. macraspis compartilham a região látero-posterior do segmento $\mathrm{X}$ intumescida e dirigida posteriormente, formando um pequeno tubérculo.

\section{Antiteuchus tripterus (Fabricius, 1787)}

(Figs. 224-231, 307)

Cimex tripterus Fabricius, 1787: 294; Gmelin, 1793: 2151; Fabricius, 1794: 116 .

Edessa triptera; Fabricius, 1803: 153. 
Dinidor punctiger Westwood, 1837: 25.

Cataulax apicalis Erichson, 1848: 609.

Antiteuchus punctiger; Dallas, 1851: 164; Walker, 1867: vol. 1, 199 (lista).

Antiteuchus tripterus; Stål, 1868: 19; Ruckes, 1961: 152.

Cataulax centralis Walker, 1867: 566.

Dinocoris (Mecistorhinus) tripterus; Stål, 1872: 8.

Dinocoris tripterus; Uhler, 1886: 5 (lista); Distant, 1880: 46, est. 5 fig. 3; Lethierry \& Severin, 1893: 86 (catálogo).

Mecistorhinus (Mecistorhinus) tripterus; Kirkaldy, 1909: 217 (catálogo). Mecistorhinus lineatus Ruckes, 1959: 2-4.

Antiteuchus (Antiteuchus) tripterus; Ruckes, 1964: 63 (chave), 76-77, figs. 8-9, 34-36; Becker \& Grazia-Vieira, 1971: 21 (lista); Engleman \& Rolston, 1983: 179 (chave).

Antiteuchus tripterus limbativentris; Ruckes, 1964: 63 (chave), 76-77, figs. 8-9, 34-36. SIN. NOV.

Antiteuchus (Antiteuchus) minor Engleman, 1983 (in Engleman \& Rolston, 1983): 179 (chave), 181-182, fig. 10. SIN. NOV.

Medidas ( $\mathrm{n}=20)$ : comprimento total- 8,5-11,8; largura total$5,1-7,2$.

Corpo achatado dorso-ventralmente, coloração dorsal variando entre o amarelo com linhas sinuosas transversais e manchas castanhas até totalmente negro com pequenas manchas amarelas dispersas sobre a superfície. Pontuação densa e distribuída em linhas transversais, principalmente sobre escutelo e pronoto, e agrupamentos irregulares sobre o hemiélitro.

Artículos antenais II e III apresentam setas entre as sétulas. Segmentos antenais I e II amarelos com pontos negros ou totalmente negros. Segmento III amarelo com manchas e 1/3 apical negros. Segmento IV negro. Segmento V amarelo com um anel proximal negro. Segmentos em ordem crescente de comprimento: II; I; III e IV subiguais; V.

Rostro amarelo a castanho-escuro. Hemiélitro com ápice atingindo a metade posterior do conexivo VII. Escutelo com ápice arredondado atingindo a metade distal do urotergito VII. Ventralmente o tórax apresenta-se amarelo com pontuação densa e escura. Área evaporatória amarela à castanho-escura. Ruga ostiolar amarela à negra. Mesopleura sem um pequeno calo amarelo-pálido. Metapleura sem um grande calo junto à margem externa. Coxas, trocânteres e tarsos amarelos a castanho-escuros e imaculados. Fêmures amarelos a amareloescuros, recobertos por manchas castanhas a negras que aumentam de densidade em direção ao ápice. Tíbias amarelas a castanho-escuras com manchas castanhas a negras; alguns pêlos são mais longos que o diâmetro do segmento. Conexivo com áreas intersegmentares negras alternadas com áreas amarelas. Coloração dorsal do abdome castanha à negra. Face ventral do abdome amarela à castanho-clara, sendo mais clara medianamente. Pode ou não ocorrer uma área amarela interna a cada espiráculo. Margem lateral sem manchas amarelas; ângulos póstero-laterais negros ou não. Exemplares provenientes da Colômbia, considerada por Ruckes (1964) como uma subespécie - A. tripterus limbativentris - possui uma faixa alaranjada longitudinal entre os tricobótrios e a margem lateral. Urotergito VII sem um par de projeções arredondadas e espessadas na margem do segmento; pêlos distribuídos por toda margem. Parte livre do processo mediano curta, estreita, plana e curvada póstero-ventralmente; ápice

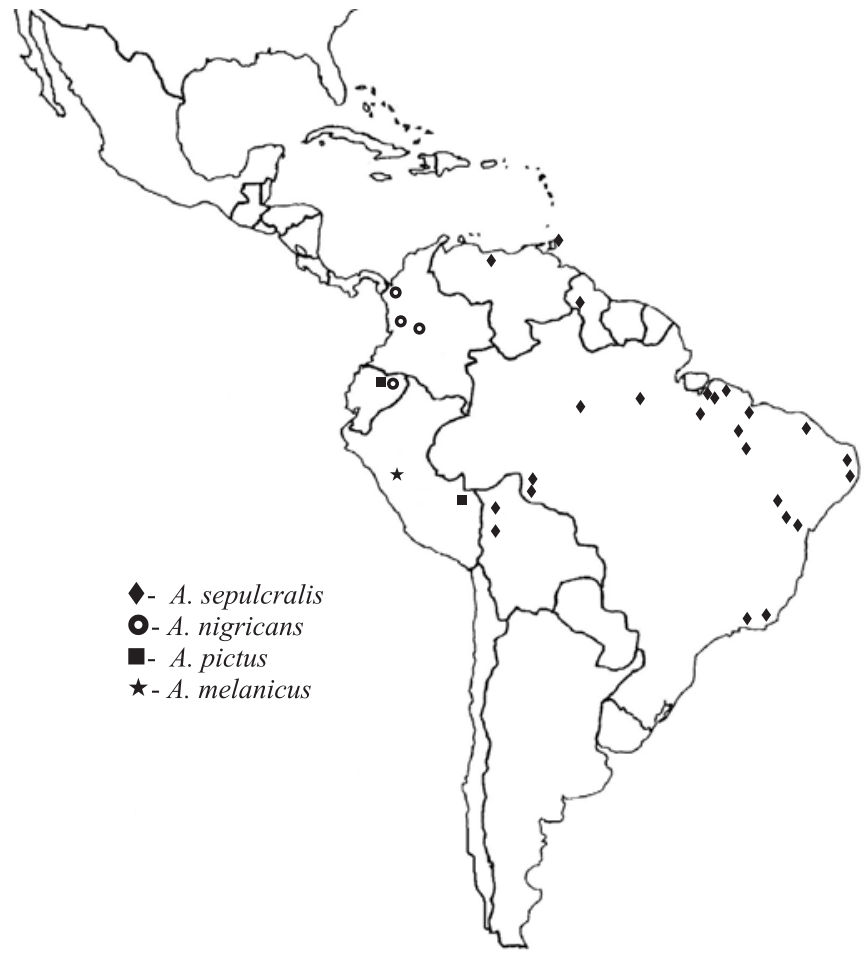

Fig. 306. Mapa de distribuição de parte das espécies do grupo A. mixtus: A. sepulcralis, A. nigricans, A. pictus e A. melanicus.

levemente expandido ou não e liso, margem posterior com uma pequena lígula membranosa (figs. 224-225). Membrana estreita na região mediana, alargando-se em direção às laterais.

Pigóforo amarelo-escuro com a superfície ventral castanhoescuro entremeado com manchas amarelas. Escavação do bordo cerca de duas vezes mais larga que profunda (fig. 226). Projeções laterais ao segmento X dentiformes ou arredondadas. Processo superior do bordo ventral arredondado, côncavo e negro, ângulo lateral interno elevado, formando uma pequena projeção arredondada fundida ao ângulo póstero-lateral do pigóforo. Em vista posterior, é possível ver uma grande concavidade na margem do bordo, onde encaixa-se o parâmero. Região mediana baixa, plana e inclinada posteriormente, margem superior côncava e tão larga quanto a extremidade do segmento X (fig. 227). Região lateral do bordo, junto ao ângulo póstero-lateral do pigóforo, com um tufo denso de pêlos longos. Abaixo da região mediana ocorre uma área côncava com uma escavação central profunda e recoberta por pêlos esparsos. Ângulo póstero-lateral do pigóforo castanhoescuro, em torno de 1,2 vezes mais longo que largo em vista lateral (fig. 228). Ângulo pouco mais longo que a área esclerotizada do segmento X. Face interna amarela e côncava. Face dorso-lateral levemente côncava e castanha com manchas amarelas. Face ventral convexa e castanha com manchas amarelas.

Cabeça do parâmero (figs. 229-231) composta por 4 lobos. Dorsal fundido com o lateral externo, alto, amplo e fortemente inclinado posteriormente, margem dorsal levemente achatada 
e rebatida na região anterior; carena dorsal inconspícua. Lobo lateral interno reniforme, amplo, envolvendo a margem do lobo dorsal, levemente convexo na face dorsal e pouco inclinado lateralmente, margem posterior espessa; ventralmente une-se ao lobo ventral por uma parede delgada, côncava e com a borda espessa. Lobo lateral externo amplo, trapezoidal, convexo e dirigido látero-anteriormente. Lobo ventral pequeno, em forma de paralelogramo e convexo, apresenta também uma pequena projeção triangular dirigida para base do ângulo póstero-lateral do pigóforo.

Segmento X globoso; região látero-posterior intumescida e dirigida posteriormente, formando ou não um pequeno tubérculo (fig. 226). Face posterior levemente convexa e muito inclinada, quase perpendicular ao plano frontal do pigóforo. Área membranosa dorsal atingindo o final da face dorsal.

C. tripterus: Holótipo fêmea. "tripterus" "Type" ( ZMUC). Examinado.

A. tripterus limbativentris: Holótipo macho. "Colombia, 6-6-1948", "Hol. S. f. Cali" "E. M. Paulsen", "24/1148" ( ZMUC ). Examinado. Ruckes (1964) acrescenta o primeiro nome do coletor, "Erik".

A. minor: Holótipo fêmea. "Madeira Mamore, Brazil, Mann." (AMNH). Examinado.

Distribuição: Panamá, Canal Zone: Ft. Clayton, Balboa. Trinidad, Trinidad: St. Augustine, Blue Range, Arima. Colômbia, Valle del Cauca: Buenaventura, Cali; Meta: Villavicencio. Venezuela, Distrito Federal: Caracas; Carabobo: Mariara; Amazonas: Puerto Ayacucho, delta do rio Amacuro. Brasil, Amazonas: Barcelos, Manaus, Benjamin Constant, Borba; Pará: Soure (Ilha de Marajó), Primavera, Belém, Sousa, Tomé-Açú, Altamira (Rod. Trans amazônica Km 70), Conceição do Araguaia; Acre: Rio Branco; Rondônia: Ouro Preto d'Oeste, Cacoal; Mato Grosso: Parque Nacional do Xingu, Utiariti, Chapada dos Guimarães; Goiás: Goiânia, Corumbá de Goiás; Minas Gerais: Uberlândia, Sete Lagoas, Divinópolis, Pouso Alegre; Mato Grosso do Sul: Corumbá, Três Lagoas, Dourados; Rio de Janeiro: Campos, Rio de Janeiro; São Paulo: Ribeirão Preto, Ibitinga, Jaú, Rio Claro, Piracicaba, Campinas, Jundiaí, São Paulo, São Sebastião, Barreira, Corumbataí; Paraná: Londrina, Curitiba; Santa Catarina: Florianópolis; Rio Grande do Sul: Barra do Quaraí, Pelotas. Equador, Napo: Coca. Perú, Amazonas: Montenegro; Huánuco: Tingo Maria, Zungaro; Cuzco: Quilabamba. Bolívia, Beni: Rurrenabaque; La Paz: Sapecho-Alto Beni. Paraguai, Central: Assunción. Argentina, Formosa: Laguna Oca; Misiones: Fracrón, Leandro Alem.

Comentários: Os exemplares analisados pertencem às coleções do AMNH, BMNH, CASC, DZUP, IBSP, UFRRJ, INPA, IZAV, MLPA, MPEG, MZSP, RMNH, UFRG, NMNH e UYIC. Esta espécie pode ou não apresentar o processo mediano do urotergito VII levemente expandido no ápice. Esta espécie pode ser reconhecida também pelo processo superior do bordo ventral do pigóforo com o ângulo lateral interno elevado, formando uma pequena projeção arredondada fundida ao ângulo póstero-lateral do pigóforo; pelo lobo dorsal do parâmero com a margem levemente achatada e rebatida; pelo lobo lateral interno reniforme, amplo e pouco inclinado

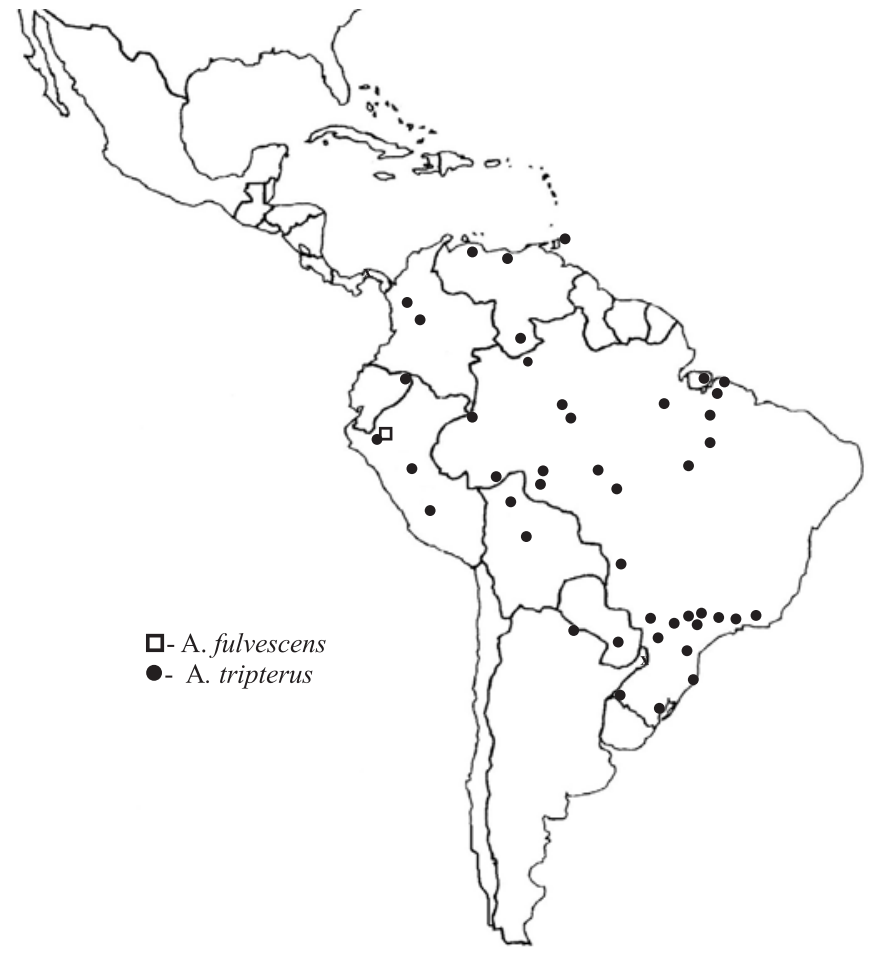

Fig. 307. Mapa de distribuição de parte das espécies do grupo A. mixtus: A. fulvescens e A. tripterus.

lateralmente; pelo lobo ventral pequeno e em forma de paralelogramo; pelo segmento X globoso. Devido ao tamanho e coloração desta espécie, ela pode ser confundida com várias espécies do grupo A. mixtus, principalmente A. sepulcralis. Todavia, a forma reniforme do lobo lateral do parâmero e a forma globosa do segmento $\mathrm{X}$ distinguem essas duas espécies.

\section{Antiteuchus maculosus Ruckes, 1964}

(Figs. 232-238, 308)

Antiteuchus (Antiteuchus) maculosus Ruckes, 1964: 64 (chave), 81, 83, figs. 45-46; Froeschner, 1981: 64 (lista); Engleman \& Rolston, 1983: 180 (chave).

Medidas ( $\mathrm{n}=14)$ : comprimento total- $12,8-13,1$; largura total8,2-8,7.

Corpo achatado dorso-ventralmente, amarelo com manchas escuras. Pontuação densa, distribuída em linhas sinuosas, geralmente transversais, e não formando agrupamentos irregulares. Os machos são mais escuros que as fêmeas.

Artículos antenais II e III apresentam setas entre as sétulas. Segmentos antenais I e II amarelos com manchas castanhoescuras. Segmento III negro com ápice e algumas manchas na metade basal amarelos. Segmento IV negro com um anel basal e ápice amarelos. Segmento V amarelo com um anel negro. Segmentos em ordem crescente de comprimento: I e II subiguais; III e IV subiguais; V.

Rostro amarelo a castanho-claro. Hemiélitro com ápice atingindo a metade posterior do conexivo VII. Escutelo com 
ápice arredondado atingindo a metade distal do urotergito VII. Ventralmente o tórax apresenta-se amarelo a amarelo-escuro com pontuação densa castanha à castanho-escura. Área evaporatória castanha. Ruga ostiolar amarelo-pálida. Mesopleura com um pequeno calo amarelo-pálido. Metapleura sem um grande calo junto à margem externa. Coxas e trocânteres amarelo-escuros e imaculados. Fêmures amarelos recobertos por manchas castanho-escuras que aumentam de densidade em direção ao ápice. Tíbias amarelas com grandes manchas negras, principalmente na superfície dorsal; alguns pêlos são mais longos que o diâmetro do segmento. Tarsos amarelos a castanho-claros. Áreas intersegmentares do conexivo castanho-escuras alternadas com áreas amarelas, pontuação densa e castanha. Coloração dorsal do abdome castanha à castanho-escura. Face ventral do abdome amarela à castanha. Ocorre uma área amarela interna a cada espiráculo. Margem lateral com uma mancha amarela em cada segmento. Urotergito VII com um par de projeções arredondadas e não espessadas; pêlos distribuídos por toda margem. Parte livre do processo mediano longa, larga, plana, elevada em relação ao tergito e curvada póstero-ventralmente; ápice expandido e levemente enrugado ou não, margem posterior com uma grande lígula membranosa. Membrana estreita na região mediana, alargandose apenas no 1/4 lateral (fig. 232).

Pigóforo amarelo com a região posterior castanho-escura entremeada com manchas amarelas. Escavação do bordo dorsal cerca de duas vezes mais larga que profunda (fig. 233). Projeções laterais ao segmento $\mathrm{X}$ arredondadas. Processo superior do bordo ventral pequeno, arredondado, plano e negro. Em vista posterior, é possível ver uma grande concavidade na margem, onde encaixa-se o parâmero. Região mediana alta, convexa transversalmente e inclinada posteriormente, margem superior côncava e mais larga que a extremidade do segmento X (fig. 234). Região lateral do bordo, junto ao ângulo póstero-lateral do pigóforo, com um tufo denso de pêlos longos. Margem do bordo, junto a extremidade ventral de cada ângulo póstero-lateral do pigóforo, apresentando um processo em forma de tubérculo (fig. 235). Abaixo da região mediana ocorre uma área côncava sem elevação central e recoberta por pêlos esparsos. Ângulo póstero-lateral do pigóforo em torno de 1,2 vezes mais longo que largo em vista lateral. Ângulo pouco mais longo que a área esclerotizada do segmento X. Face interna côncava e castanho-clara. Face dorso-lateral levemente côncava, apresentando uma pequena elevação em continuação ao processo látero-dorsal, e castanho-escura com várias manchas amarelas. Face ventral plana e castanho-escura.

Cabeça do parâmero (figs. 236-238) composta por 4 lobos. Dorsal fundido ao lateral externo, amplo, baixo e inclinado posteriormente, margem dorsal espessa e apresentando um grande processo triangular rebatido lateralmente, região anterior da margem achatada e levemente rebatida; carena dorsal inconspícua. Lobo lateral interno longo, estreito, delgado, curvado posteriormente e com ápice arredondado. Lobo lateral externo grande, triangular e curvado anteriormente. Lobo ventral amplo, sub-retangular, levemente côncavo e

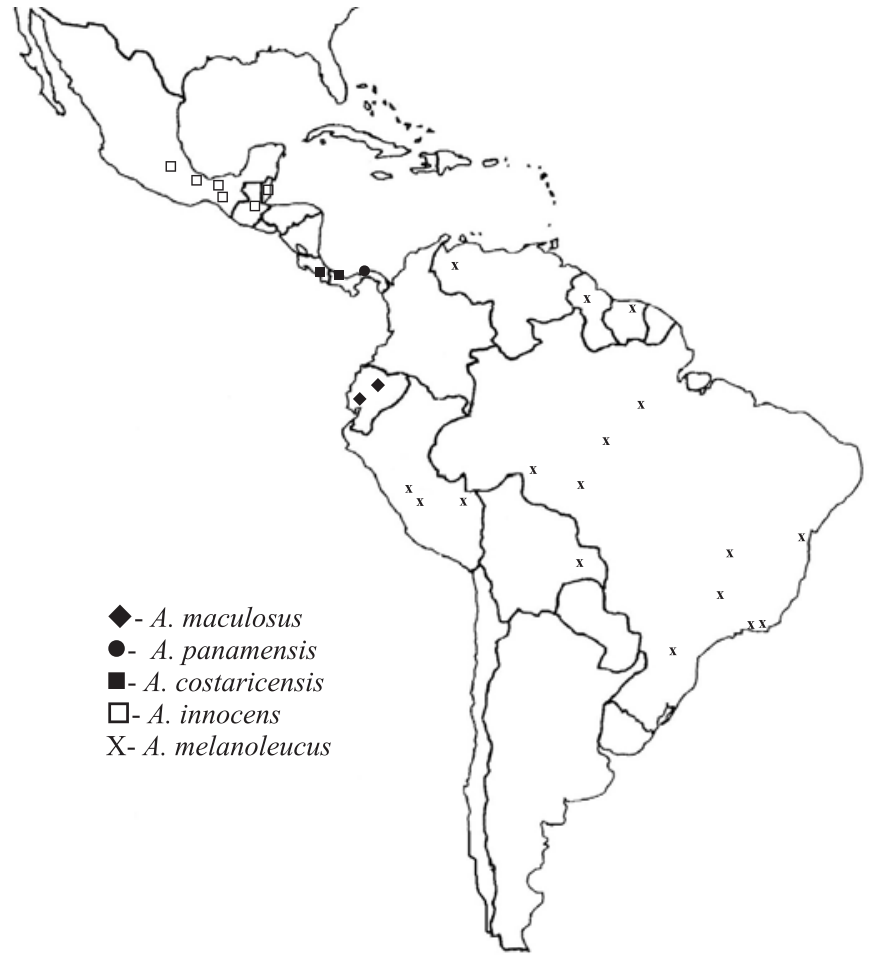

Fig. 308. Mapa de distribuição de parte das espécies do grupo A. mixtus: A. maculosus, A. panamensis, A. costaricensis, A. innocens e A. melanoleucus.

dirigido ventralmente, margem lateral com um grande processo espiniforme dirigido anteriormente.

Segmento X semicilíndrico; região látero-posterior intumescida e dirigida posteriormente, formando ou não um pequeno tubérculo (fig. 233). Face posterior convexa transversalmente. Área membranosa dorsal atingindo o final da face dorsal.

Holótipo macho. "Ecuador Occidental", "F. Campos collector" (NMNH). examinado.

Distribuição: Equador, Guayas: Guayaquil, Duran; Tungurahua: Baños.

Comentários: Os exemplares analisados pertencem às coleções do AMNH, BMNH, CASC, MCNZ, UFRG e NMNH. Esta espécie pode ser distinguida das demais por apresentar sobre o urotergito VII um par de projeções arredondadas e não espessadas; pelo processo superior do bordo ventral do pigóforo pequeno; pela margem do lobo dorsal do parâmero espessa com um grande processo triangular rebatido lateralmente em sua região mediana; pelo lobo ventral amplo e sub-retangular. A. maculosus apresenta em comum $\operatorname{com} A$. panamensis a parte livre do processo mediano do urotergito VII elevada em relação ao tergito; e o lobo lateral interno longo, e curvado posteriormente. A. maculosus, A panamensis e $A$. innocens apresentam em comum o lobo lateral interno do parâmero estreito e com ápice arredondado. A. maculosus 
compartilha com $A$. panamensis, $A$. costaricensis e $A$. innocens a presença de uma grande lígula membranosa na margem do processo mediano do urotergito VII, esta lígula é tão grande quanto a área expandida do processo mediano; a margem da superfície ventral, junto a extremidade ventral de cada ângulo póstero-lateral do pigóforo, apresentando um processo em forma de tubérculo; a região mediana do bordo ventral do pigóforo alta, convexa transversalmente, inclinada posteriormente e margem côncava; o lobo ventral do parâmero amplo, levemente côncavo e dirigido ventralmente. $A$. maculosus compartilha com A. panamensis, A. costaricensis, A. innocens, A. melanoleucus, A. mixtus, A. radians, $A$. macraspis, $A$. schuhi e $A$. variegatus, o ápice do processo mediano do urotergito VII enrugado.

Antiteuchus panamensis (Ruckes, 1959)

(Figs. 239-245, 308)

Mecistorhinus panamensis Ruckes, 1959: 4.

Antiteuchus panamensis; Ruckes, 1961: 152.

Antiteuchus (Antiteuchus) panamensis; Ruckes, 1964: 63 (chave), $72-$

73, figs. 1, 6, 27-28; Engleman \& Rolston, 1983: 179 (chave).

Medidas ( $\mathrm{n}=20)$ : comprimento total- 11,2-13,1; largura total7,1-8,5.

Corpo achatado dorso-ventralmente, coloração dorsal variegada com manchas amarelas e castanhas. Pontuação densa, distribuída em linhas sinuosas, geralmente transversais, e formando agrupamentos irregulares sobre o hemiélitro. Machos e fêmeas apresentam exemplares escuros e claros.

Artículos antenais II e III apresentam setas entre as sétulas. Estes mesmos artículos antenais apresentam pêlos muito longos e eriçados entre as sétulas e setas. Segmentos antenais I e II variando de cor entre amarelos com manchas castanhas até uniformemente castanho-escuros. Segmentos III, IV e V negros com a base e o ápice amarelos. Segmentos em ordem crescente de comprimento: I e II subiguais; III e IV subiguais; $\mathrm{V}$.

Rostro amarelo a castanho-escuro. Hemiélitro com ápice atingindo a metade posterior do conexivo VII. Escutelo com ápice arredondado atingindo a metade distal do urotergito VII. Ventralmente o tórax apresenta-se amarelo a castanho com pontuação castanho-escura. Área evaporatória castanha. Ruga ostiolar negra com ápice amarelo. Mesopleura com ou sem um pequeno calo amarelo-pálido. Metapleura sem um grande calo junto à margem externa. Coxas e trocânteres amarelos a castanho-escuros e imaculados. Fêmures amarelos recobertos por manchas castanhas a negras que aumentam de densidade em direção ao ápice. Tíbias amarelas com grandes manchas negras; alguns pêlos são mais longos que o diâmetro do segmento. Tarsos amarelos a negros. Conexivo com áreas intersegmentares castanho-claras a negras alternadas com áreas amarelas; pontuação densa e castanha. Coloração dorsal do abdome castanho-clara à castanho-escura. Face ventral do abdome amarela à castanho-escura. Ocorre ou não uma área amarela interna a cada espiráculo. Margem lateral com ou sem uma mancha amarela em cada segmento. Urotergito VII com

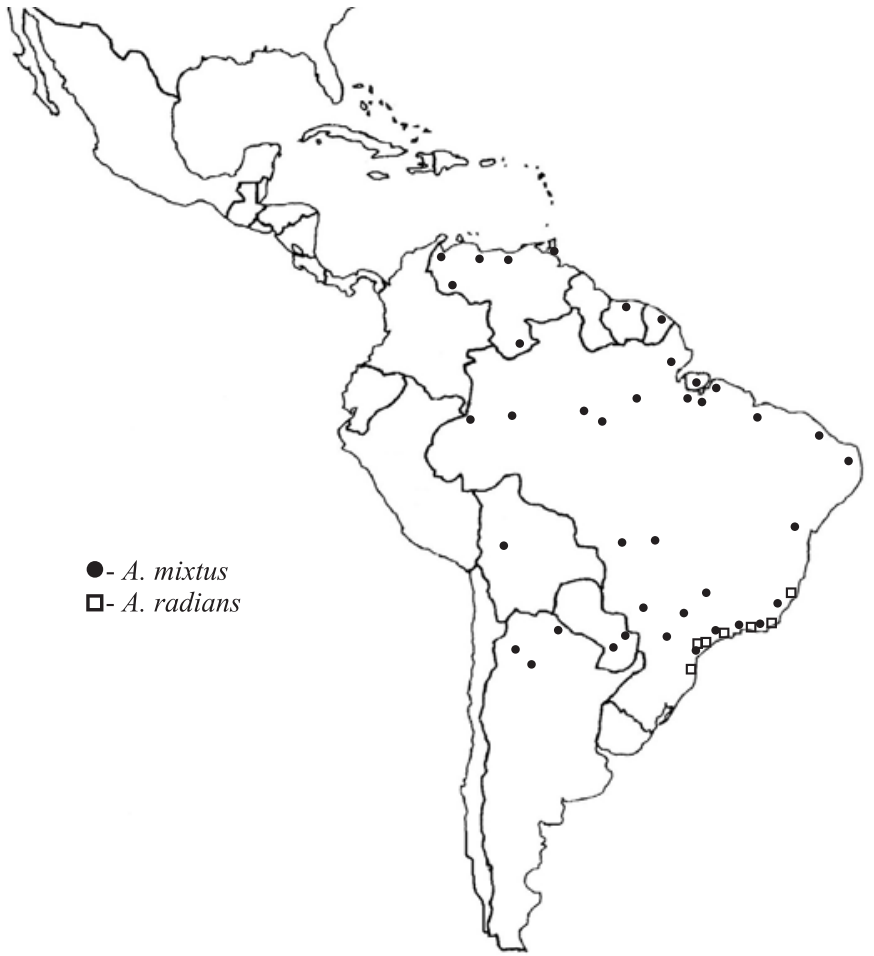

Fig. 309. Mapa de distribuição de parte das espécies do grupo A. mixtus: A. mixtus e $A$. radians.

um par de projeções arredondadas, espessadas e com textura diferenciada na região mediana entre o processo e a margem do urotergito VII; pêlos distribuídos ao longo de toda margem. Parte livre do processo mediano longa, estreita, plana, elevada em relação ao tergito e curvada póstero-ventralmente; ápice expandido e levemente enrugado, margem posterior com uma lígula membranosa grande. Membrana quase inconspícua na região mediana, alargando-se após a projeção espessada (fig. 239).

Pigóforo amarelo-escuro com a região posterior castanha entremeada com manchas amarelas. Escavação do bordo dorsal cerca de quatro vezes mais larga que profunda (fig. 240). Projeções laterais ao segmento $\mathrm{X}$ arredondadas. Processo superior do bordo ventral grande, arredondado, plano e negro. Em vista posterior é possível ver uma grande concavidade na margem, onde encaixa-se o parâmero. Região mediana alta, levemente convexa transversalmente e inclinada posteriormente, margem superior biconvexa e tão larga quanto a extremidade do segmento X (fig. 241). Região lateral do bordo, junto ao ângulo póstero-lateral do pigóforo, com um tufo denso de pêlos longos associado a uma protuberância. Margem do bordo, junto a extremidade ventral de cada ângulo pósterolateral do pigóforo, apresentando um processo em forma de tubérculo (fig. 242). Abaixo da região mediana ocorre uma área côncava sem elevação central e recoberta por pêlos esparsos. Ângulo póstero-lateral do pigóforo em torno de 1,3 vezes mais longo que largo em vista lateral. Ângulo mais longo que a área esclerotizada do segmento X. Face interna côncava. Face dorso- 
lateral côncava, apresentando uma pequena elevação em continuação ao processo látero-dorsal. Face ventral plana.

Cabeça do parâmero (figs. 243-245) composta por 4 lobos. Dorsal fundido ao lateral externo, amplo, baixo e inclinado posteriormente, margem superior levemente espessada e rebatida lateralmente, anteriormente ocorre uma pequena área achatada e projetada látero-anteriormente; carena dorsal inconspícua. Lobo lateral interno longo, estreito, delgado e curvado póstero-ventralmente, ápice arredondado. Lobo lateral externo grande, subtriangular e curvado láteroanteriormente. Lobo ventral amplo, subtriangular, levemente côncavo e dirigido ventralmente, ângulo póstero-lateral externo formando uma projeção triangular curvada em direção à base do ângulo póstero-lateral do pigóforo; margem lateral do lobo projeta-se internamente sobre a projeção triangular formando uma pequena aba delgada e convexa.

Segmento X semicilíndrico; região látero-posterior intumescida e dirigida posteriormente, formando ou não um pequeno tubérculo (fig. 240). Face posterior levemente convexa. Área membranosa dorsal atingindo o final da face dorsal.

Holótipo macho. "Barro Colorado, C. Z., I.24.41, K. W. Cooper" (AMNH). Examinado.

Distribuição: Panamá, Canal Zone: Ancon, Coco Solo Hospital ( $\left.9^{\circ} 21^{\prime} \mathrm{N} 79^{\circ} 51^{\prime} \mathrm{W}\right)$, Corozal, Ft. Gulish, Ilha Barro Colorado, lago Gatún, Paraíso, Rio Trinidad, Taboga I.

Comentários: Os exemplares analisados pertencem às coleções do AMNH, BMNH, CASC, SEMC, MCNZ e NMNH. Esta espécie é facilmente reconhecida por possuir pêlos muito longos e eriçados entre as sétulas e setas dos artículos antenais II e III; pela membrana do urotergito VII quase inconspícua na região mediana, alargando-se após a projeção espessada do urotergito VII; pela região lateral da superfície ventral, junto ao ângulo póstero-lateral do pigóforo, com um tufo denso de pêlos longos associado a uma protuberância; pela margem do lobo dorsal do parâmero levemente espessado e rebatido lateralmente; pelo lobo ventral subtriangular; pela margem lateral do lobo ventral se projetando internamente sobre a projeção triangular formando uma pequena aba delgada e convexa. A. panamensis, A. costaricensis e A.innocens apresentam em comum uma escavação rasa na margem do bordo dorsal do pigóforo; uma aba que se origina na margem do lobo ventral do parâmero e projeta-se sobre o próprio lobo; o processo superior do bordo ventral do pigóforo grande e plano; e o lobo ventral subtriangular. A. panamensis compartilha com A. costaricensis, A.innocens, A. mixtus, $A$. radians, $A$. macraspis, $A$. schuhi e $A$. variegatus, a presença, sobre o urotergito VII, de um par de projeções arredondadas, espessadas e com textura própria, cada uma localizada na região mediana entre o processo e a margem do urotergito VII.

Antiteuchus costaricensis Ruckes, 1964 (Figs. 246-252, 308)

Antiteuchus (Antiteuchus) costaricensis Ruckes, 1964: 64 (chave), 80-

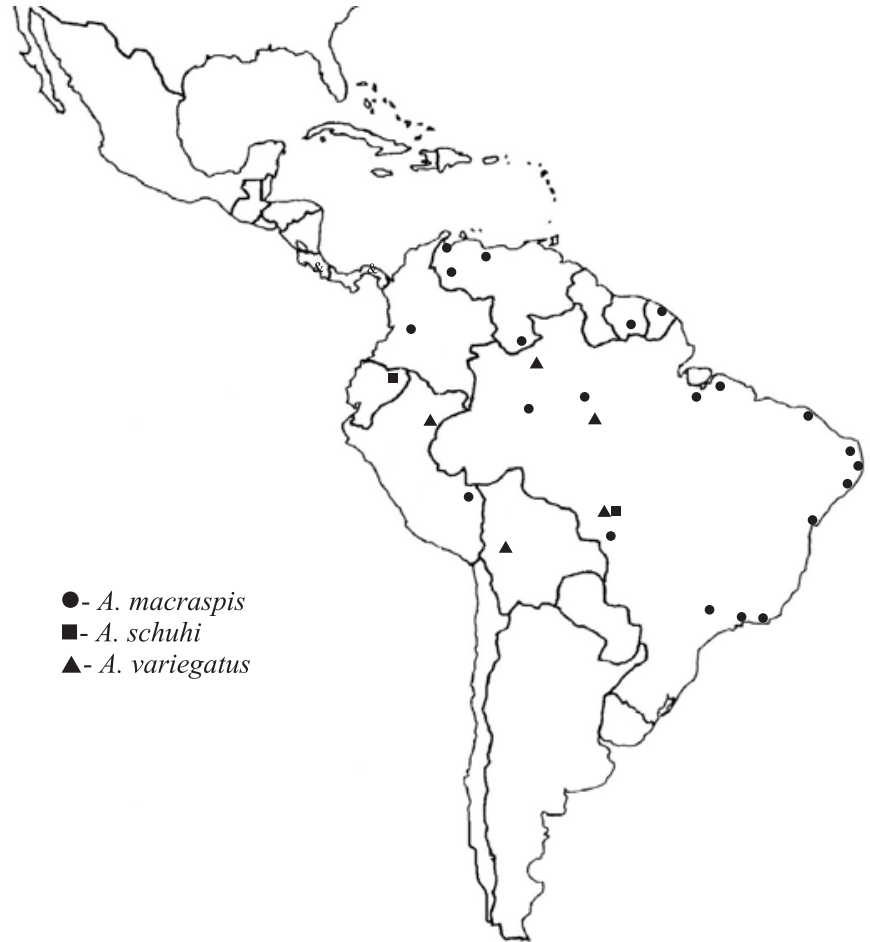

Fig. 310. Mapa de distribuição de parte das espécies do grupo A. mixtus: A. macraspis, A. schuhi e A. variegatus.

81, figs. 40-41; Engleman \& Rolston, 1983: 180 (chave), 182-183, fig. $4 \mathrm{c}$.

Medidas $(\mathrm{n}=20)$ : comprimento total- 10,8-12,1; largura total- 6,9-7,4.

Corpo achatado dorso-ventralmente, coloração dorsal variando entre amarela com pequenas manchas castanhas até quase totalmente negra. Pontuação densa, distribuída em linhas sinuosas, geralmente transversais, e não formando agrupamentos irregulares.

Artículos antenais II e III apresentam setas entre as sétulas. Segmento antenal I amarelo a castanho-escuro com manchas castanhas a negras. Segmento II negro com ou sem pequenas manchas amarelas. Segmento III negro com ou sem ápice amarelo. Segmento IV negro com um anel basal amarelo. Segmento V negro com um anel basal e ápice amarelos. Segmentos em ordem crescente de comprimento: II; I; III e IV subiguais; V.

Hemiélitro com ápice atingindo a metade posterior do conexivo VII. Escutelo com ápice arredondado atingindo a metade distal do urotergito VII. Ventralmente o tórax apresentase amarelo a amarelo-escuro com pontuação densa castanha à castanho-escura. Área evaporatória castanha. Ruga ostiolar castanha com ápice amarelo-pálido. Mesopleura com ou sem um pequeno calo amarelo-pálido. Coxas, trocânteres e tarsos amarelos a castanho-claros e imaculados. Fêmures amarelos a amarelo-escuros recobertos por manchas castanho-escuras a negras que aumentam de densidade em direção ao ápice. Tíbias amarelas com grandes manchas castanhas a negras; alguns 
pêlos são mais longos que o diâmetro do segmento. Conexivo com as áreas intersegmentares negras alternadas com áreas amarelas. Coloração dorsal do abdome castanha à castanhoescura. Face ventral do abdome amarela à castanho-clara. Ocorre ou não uma área amarela interna a cada espiráculo. Margem lateral sem manchas e com ângulos ântero e pósterolaterais de cada segmento negros. Urotergito VII com um par de projeções arredondadas, espessadas e com textura diferenciada, localizada na região mediana entre o processo e a margem do urotergito VII; pêlos distribuídos ao longo de toda margem. Parte livre do processo mediano longa, estreita na base, plana e curvada póstero-ventralmente; ápice expandido e levemente enrugado; lígula membranosa tão grande quanto a área expandida. Membrana reduzida na projeção espessada (fig. 246).

Pigóforo amarelo-escuro com superfície ventral castanha e entremeada com manchas amarelas. Escavação do bordo dorsal cerca de oito vezes mais larga que profunda (fig. 247). Projeções laterais ao segmento $\mathrm{X}$ arredondadas. Processo superior do bordo ventral grande, plano e castanho-escuro. Em vista posterior, é possível ver uma pequena concavidade na margem do bordo, onde encaixa-se o parâmero. Região mediana alta, convexa transversalmente e inclinada posteriormente, margem superior côncava e mais larga que a extremidade do segmento X (fig. 248). Região lateral do bordo, junto ao ângulo pósterolateral do pigóforo, com um tufo denso de pêlos longos. Margem do bordo, junto a extremidade ventral de cada ângulo pósterolateral do pigóforo, apresentando um processo em forma de tubérculo (figs. 249). Abaixo da região mediana ocorre uma área côncava sem elevação central, com manchas castanhoclaras e recoberta por pêlos esparsos. Ângulo póstero-lateral do pigóforo em torno de 1,3 vezes mais longo que largo em vista lateral. Ângulo mais longo que a área esclerotizada do segmento X. Face interna plana e amarela. Face dorso-lateral convexa, amarela com o ápice castanho. Face ventral plana ou levemente convexa, amarela com manchas castanhas que podem recobrir a maior parte da face.

Cabeça do parâmero (figs. 250-252) composta por 4 lobos. Dorsal fundido ao lateral externo, amplo, alto e inclinado posteriormente, margem dorsal com uma área grande, triangular, achatada e projetada anteriormente; carena dorsal baixa, terminando sobre o lobo lateral interno. Lobo lateral interno longo, largo, delgado, levemente convexo, curvado pósteroventralmente e com ápice truncado. Lobo lateral externo pequeno, formado por uma convexidade da parede. Lobo ventral amplo, triangular, convexo e dirigido posteriormente, lateralmente existe uma projeção triangular longa, larga e curvada em direção à base do ângulo póstero-lateral do pigóforo; margem lateral do lobo projeta-se internamente sobre a projeção triangular formando uma aba delgada, lingüiforme, levemente convexa e dirigida ventralmente. Esta aba inicia na base da projeção e prolonga-se internamente, sob a forma de uma carena alta que cruza o parâmero, até o lobo lateral interno.

Segmento X semicilíndrico; região látero-posterior intumescida e dirigida posteriormente, formando ou não um pequeno tubérculo (fig. 247). Face posterior plana. Área membranosa dorsal atingindo o final da face dorsal.

Holótipo macho. "Turrialba, Costa Rica, June 16, 1948; Franz Schrader coll.” (AMNH). Examinado.

Distribuição: Costa Rica, Guapiles, Puntarenas, Caldeira, La Lola, Tucurrique. Panamá, Bocas del Toro: Bocas del Toro, Damas.

Comentários: Os exemplares analisados pertencem às coleções do AMNH, CASC, BMNH, UFRG e NMNH. Esta espécie pode ser reconhecida pela escavação do bordo dorsal do pigóforo limitada a uma concavidade muito rasa; pela margem do lobo dorsal do parâmero com uma área grande, triangular e achatada; pelo lobo lateral interno longo, largo, levemente convexo e com ápice truncado; pela carena que dá continuidade à aba do lobo ventral do parâmero prolonga-se até o lobo lateral interno. A. costaricensis e A. innocens apresentam em comum o lobo ventral do pigóforo convexo e dirigido posteriormente; e a margem lateral do lobo ventral do parâmero formando uma aba lingüiforme que se projeta muito sobre o lobo.

Antiteuchus innocens Engleman, 1983

(Figs. 253-259, 308)

Antiteuchus innocens Engleman, 1983 (in Engleman \& Rolston, 1983): 180 (chave), 182-183, figs. 3, 4b.

Dinocoris piceus; Distant, 1880: 47, est. 5, fig. 4, 324 (suplemento).

Medidas $(\mathrm{n}=20)$ : comprimento total- 10,3-12,5; largura total- 6,6-7,5.

Corpo achatado dorso-ventralmente, coloração dorsal variando entre amarela com pequenas manchas castanhas até quase totalmente negra. Pontuação densa, distribuída em linhas sinuosas não formando agrupamentos irregulares. Machos e fêmeas são representados por exemplares escuros e claros.

Artículos antenais II e III apresentam setas entre as sétulas. Segmento antenal I amarelo com manchas castanho-escuras. Segmento II amarelo a castanho-escuro. Segmentos III negro com ou sem manchas castanho-escuras. Segmento IV negro com ou sem um anel basal amarelo. Segmento V negro com um anel basal e ápice amarelos. Segmentos em ordem crescente de comprimento: I e II subiguais; III e IV subiguais; V.

Hemiélitro com ápice atingindo a metade posterior do conexivo VII. Escutelo com ápice arredondado atingindo a metade distal do urotergito VII. Ventralmente o tórax apresentase amarelo a amarelo-escuro com pontuação densa castanha à castanho-escura. Área evaporatória castanha. Ruga ostiolar castanho-escura na metade basal e amarelo-pálida na posterior. Mesopleura com ou sem um pequeno calo amarelo-pálido. Metapleura sem um grande calo junto à margem externa. Coxas e trocânteres amarelos a amarelo-escuros e imaculados. Fêmures amarelos recobertos por manchas castanho-escuras que aumentam de densidade em direção ao ápice. Tíbias amarelas com grandes manchas castanhas a negras; alguns 
pêlos são mais longos que o diâmetro do segmento. Tarsos amarelos a castanhos. Conexivo com áreas intersegmentares negras alternadas com áreas amarelas; pontuação densa e castanha. Coloração dorsal do abdome castanha. Face ventral do abdome amarela à castanho-clara. Ocorre uma área amarela interna a cada espiráculo. Margem lateral sem manchas e com ângulos ântero e póstero-laterais de cada segmento negros. Urotergito VII com um par de projeções arredondadas, espessadas e com textura diferenciada, localizada na região mediana entre o processo e a margem do urotergito VII; pêlos distribuídos ao longo de toda margem. Parte livre do processo mediano longa, larga, plana e curvada póstero-ventralmente; ápice expandido e levemente enrugado, margem posterior com uma lígula membranosa tão grande quanto a área expandida. Membrana reduzida apenas na projeção espessada (fig. 253).

Pigóforo amarelo. Escavação do bordo dorsal reduzida a uma concavidade rasa, cerca de quatro vezes mais larga que profunda (fig. 254). Projeções laterais ao segmento $X$ arredondadas. Processo superior do bordo ventral grande, arredondado, plano e negro. Em vista posterior, é possível ver uma grande concavidade na margem do bordo, onde encaixase o parâmero. Região mediana alta, convexa transversalmente e inclinada posteriormente, margem superior côncava e mais larga que a extremidade do segmento X (fig. 255). Região lateral do bordo, junto ao ângulo póstero-lateral do pigóforo, com um tufo denso de pêlos longos. Margem do bordo, junto a extremidade ventral de cada ângulo póstero-lateral do pigóforo, apresentando um processo em forma de tubérculo (figs. 256). Abaixo da região mediana ocorre uma área côncava sem elevação central, com manchas castanho-claras e recoberta por pêlos esparsos. Ângulo póstero-lateral do pigóforo em torno de 1,4 vezes mais longo que largo em vista lateral. Ângulo pouco mais longo que a área esclerotizada do segmento $\mathrm{X}$. Face interna levemente côncava e com a margem castanhoclara. Face dorso-lateral côncava e com manchas castanhas junto ao ápice. Face ventral plana ou levemente convexa com manchas castanho-claras.

Cabeça do parâmero (figs. 257-259) composta por 4 lobos. Dorsal fundido ao lobo lateral externo, amplo, alto e inclinado posteriormente, margem dorsal com uma grande área subretangular, achatada e projetada anteriormente; carena dorsal baixa, terminando sobre o lobo lateral interno. Lobo lateral interno curto, estreito, delgado, reto e dirigido láteroposteriormente. Lobo lateral externo quase inconspícuo, restrito a uma pequena convexidade da parede, junto ao lobo ventral. Lobo ventral amplo, triangular, côncavo e dirigido posteriormente, lateralmente existe uma projeção lingüiforme, larga, longa, côncava transversalmente e curvada láteroanteriormente; margem lateral do lobo projeta-se internamente sobre a projeção lingüiforme formando uma aba delgada, lingüiforme, levemente convexa e dirigida ventralmente. Esta aba inicia na base da projeção e prolonga-se internamente, sob a forma de uma carena alta que cruza o parâmero, até a margem do lobo lateral interno.

Segmento $\mathrm{X}$ semicilíndrico; região látero-posterior intumescida e dirigida posteriormente, formando ou não um pequeno tubérculo (fig. 254). Face posterior plana. Área membranosa dorsal atingindo o final da face dorsal.

Holótipo macho. "Belize, Bel., Mile 30 Western Highway Aug. 14, 1977, C. W. \& L. O’Brien \& Marshall” (NMNH). Examinado.

Distribuição: México, San Luis Potosi: El Salto, Ciudad Valles; Vera Cruz: Tecolutla; Tabasco: Teapa; Chiapas: Palenque. Belize, Belize City, San Antonio, Punta Gorda. Guatemala, Izabal: Matias de Galvez; Vera Paz: Chacoj, La Tinta.

Comentários: Os exemplares considerados por Distant (1880: 47; 1889: 324, suplemento) como pertencentes a Dinocoris piceus, com os seguintes dados de coleta: Belize (Blancaneaux col.), Guatemala: La Tinta (Champion col.), México: Teapa, in Tabasco (H. H. Smith col.) e Guatemala: Panzos, Chacoj (Champion col.), foram examinados e identificados como espécimes de $A$. innocens. O exemplar coletado em David, Chiriqui, Panamá, não foi examinado, mas com base na sua procedência, não deve pertencer a $A$. innocens; talvez seja um exemplar de $A$. panamensis ou $A$. costaricensis. Os exemplares de $A$. innocens analisados pertencem às coleções do AMNH, BMNH, CASC, SEMC, UFRG e NMNH. Esta espécie pode ser reconhecida pela margem do lobo dorsal do parâmero apresentando uma grande área achatada e projetada anteriormente; pelo lobo lateral interno do parâmero curto, estreito e reto; e pela carena que dá continuidade à aba do lobo ventral prolonga-se até a margem do lobo lateral interno. Esta espécie pode ser confundida com A. costaricensis devido ao tamanho e forma do pigóforo. Entretanto, distingui-se facilmente desta pela forma e comprimento do lobo lateral interno do parâmero e pelo local onde termina a carena que dá continuidade à aba do lobo ventral.

Antiteuchus melanoleucus (Westwood, 1837) (Figs.260-266, 308)

Dinidor melanoleucus Westwood, 1837: 24.

Empicoris renggerii Herrich-Schäffer, 1844 (8): 45.

Antiteuchus melanoleucus; Dallas, 1851: 164; Walker, 1867: vol. 1, 199 (lista); Ruckes, 1961: 152

Antiteuchus nigricornis Stål, 1859; 223-224; Stål, 1860: 18; Walker, 1867: vol. 1, 199 (lista).

Dinicoris (Mecistorhinus) melanoleucus; Stål, 1872: 8.

Dinicoris melanoleucus; Lethierry \& Severin, 1893: 86 (catálogo).

Mecistorhinus (Mecistorhinus) melanoleucus; Kirkaldy, 1909: 217 (catálogo).

Antiteuchus (Antiteuchus) melanoleucus; Ruckes, 1964: 63 (chave), 78-79, figs. 37-38; Engleman \& Rolston, 1983: 179 (chave).

Medidas (n=20): comprimento total- 11,8-15,1; largura total7,8-9,7.

Corpo levemente giboso, coloração dorsal variando entre amarelo com manchas castanhas até negro com pequenas manchas amarelas. Podem ocorrer machos claros e fêmeas escuras. Pontuação pouco densa distribuída em agrupamentos de diferentes tamanhos, raramente formando linhas sinuosas transversais. 
Artículos antenais II e III apresentam setas entre as sétulas. Segmento antenal I negro com ou sem manchas mais claras. Segmentos II-V negros. Segmentos em ordem crescente de comprimento: II; I; III-V subiguais.

Rostro amarelo a amarelo-escuro. Hemiélitro com ápice atingindo a metade posterior do conexivo VII. Escutelo com ápice arredondado atingindo a metade distal do urotergito VII. Ventralmente o tórax apresenta-se amarelo com pontuação densa castanha à castanho-escura. Área evaporatória castanho à castanho-escura. Ruga ostiolar castanha com a metade distal amarelo-pálida. Mesopleura com um pequeno calo amarelo-pálido. Metapleura com uma pequena área calosa e amarela junto à margem externa. Coxas e trocânteres amarelos e imaculados. Fêmures amarelos recobertos por manchas castanhas que aumentam de densidade em direção ao ápice, onde o segmento é quase totalmente escuro. Tíbias amarelas ou vermelhas com dois anéis negros largos; alguns pêlos são mais longos que o diâmetro do segmento. Tarsos amarelos ou vermelhos. Conexivo apresentando áreas intersegmentares castanhas alternadas com áreas amarelas; pontuação rara ou inexistente. Coloração dorsal do abdome amarelo-escura. Face ventral do abdome amarela à castanho-escura. Espiráculos e tricobótrios podem ser circundados por faixas amarelas. Margem de cada segmento com uma mancha amarela que coincide com a região amarela do conexivo. Urotergito VII sem um par de projeções arredondadas e espessadas; pêlos distribuídos por toda margem. Parte livre do processo mediano curta, larga, plana e curvada póstero-ventralmente; ápice levemente expandido e suavemente enrugado, margem posterior com uma grande lígula membranosa. Membrana inconspícua na região mediana, alargando-se em direção às laterais (fig. 260).

Pigóforo amarelo-escuro com a região posterior escura entremeada com áreas amarelas. Escavação do bordo dorsal cerca de duas vezes mais larga que profunda (fig. 261). Projeções laterais ao segmento $\mathrm{X}$ arredondadas. Processo superior do bordo ventral grande, arredondado, plano e negro. Em vista posterior, é possível ver uma grande concavidade na margem, onde encaixa-se o parâmero. Região mediana alta, convexa transversalmente e inclinada posteriormente, margem superior côncava e tão larga quanto a extremidade do segmento $X$ (fig. 262). Região lateral da superfície ventral, junto ao ângulo póstero-lateral do pigóforo, com um tufo denso de pêlos longos. Abaixo da região mediana ocorre uma área côncava sem elevação central e recoberta por pêlos esparsos. Ângulo póstero-lateral do pigóforo cerca de 1,2 vezes mais longo que largo em vista lateral (fig. 263). Ângulo mais curto que a área esclerotizada do segmento X. Face interna côncava. Face dorso-lateral convexa, apresentando uma elevação estreita e curta em continuação ao processo látero-dorsal. Face ventral levemente convexa.

Cabeça do parâmero (figs. 264-266) totalmente diferente do plano básico do gênero; portanto, torna-se difícil traçar um paralelo entre os lobos, com exceção do ventral. O lobo maior é amplo, ovalado, colocado transversalmente e levemente convexo. Sobre este lobo ocorre uma projeção alta, delgada e em forma de "Y", uma de suas partes funde-se ao lobo maior e a outra projeta-se ventralmente formando uma aba delgada que passa por baixo do lobo maior, fundindo-se a ele no ápice. Este lobo ventral apresenta junto ao ápice uma projeção triangular curvada em direção à base do ângulo póstero-lateral do pigóforo.

Segmento X semicilíndrico; região látero-posterior intumescida e dirigida posteriormente, formando ou não um pequeno tubérculo (fig. 261). Face posterior plana. Área membranosa dorsal atingindo a metade da face posterior.

Holótipo fêmea. "melanoleucus Hope", "Dinidor melanoleucus Westwood", "Type Westwood (Hope) C. Hemipt. 1837 Part I, page 24; Distant, PZS, 1900, p. 807-825", Type Hem n ${ }^{\circ} 105$ Dinidor tesselatus Westwood Hope Dept. Oxford" (OXUM). Examinado.

Distribuição: VENEZUELA, Tachira: Rio Frio. Guiana, Issonovo. Suriname, Brokopondo: Paramaribo. Brasil, Amazonas: Borba; Pará: Medicilândia (Rod. transamazônica Km 98/107); Rondônia: Porto Velho; Mato Grosso: Sinop; Bahia: Ilhéus; Minas Gerais: Timótheo, Lagoa Santa, Bom Despacho; Espirito Santo: Baixo Guandú; Rio de Janeiro: Rezende, Itaguaí, Rio de Janeiro, Campo Grande; Paraná. Perú. Huánuco: Tingo Maria; Madre de Dios: Puerto Maldonado; Junin: Junin. Bolívia. Santa Cruz: Buena Vista.

Comentários: Os exemplares analisados pertencem às coleções do AMNH, BMNH, CASC, IMLA, MCZN, MPEG, MZSP, MNRJ, RMNH, UFPR, UFRG e NMNH. Esta espécie pode ser reconhecida pelo urotergito VII sem um par de projeções arredondadas e espessadas e pêlos distribuídos por toda margem posterior (ver comentários de $A$. sepulcralis); pela coloração dorsal amarela com grandes manchas castanhoescuras para ambos os sexos, embora os machos possam ser predominantemente negros com pequenas manchas amarelas sobre toda superfície dorsal do corpo; pela pontuação dorsal pouco densa; pela membrana inconspícua na região mediana, alargando-se em direção às laterais; pelo ângulo póstero-lateral do pigóforo mais curto que a área esclerotizada do segmento $\mathrm{X}$; pela forma do parâmero, que não possui paralelo dentro do gênero. A. melanoleucus e $A$. radians possuem em comum a pontuação pouco profunda e presença de uma região amarela no ângulo ântero-lateral da metapleura. A. melanoleucus é semelhante a $A$. mixtus e $A$. radians no tocante aos pontos da superfície dorsal distribuídos em agrupamentos irregulares de diferentes tamanhos. A. melanoleucus, A. macraspis, A. schuhi e $A$. variegatus apresentam em comum o corpo levemente giboso. A. melanoleucus, A. mixtus, A. radians, A. macraspis, A. schuhi e $A$. variegatus compartilham a presença de uma área calosa amarela no ângulo ântero-lateral da metapleura.

Antiteuchus mixtus (Fabricius, 1787) (Figs. 267-273, 309)

Stoll, 1788, fig 173 .

Cimex mixtus Fabricius, 1787: 294; Gmelin, 1793: 2151; Fabricius, 1794: 115 .

Edessa mixta; Fabricius, 1803: 153 
Pentatoma picea Palisot de Beauvois, 1808: 148, est. 10, fig. 3. SIN. NOV.

Dinidor variolosus Westwood, 1837: 25. SIN. NOV.

Dinidor unicolor Westwood, 1837: 25.

Antiteuchus variolosus; Dallas, 1851: 164; Walker, 1867: vol. 1, 199 (lista); Ruckes, 1961: 152.

Antiteuchus piceus; Dallas, 1851: 165; Walker, 1867: vol. 1, 199 (lista); Ruckes, 1961: 152.

Antiteuchus mixtus Stål, 1868: 19; Ruckes, 1961: 152.

Dinocoris (Mecistorhinus) piceus; Stål, 1872: 8.

Dinocoris (Mecistorhinus) mixtus; Stål, 1872: 9.

Dinocoris (Mecistorhinus) variolosus; Stål, 1872: 9.

Dinocoris (Mecistorhinus ?) unicolor; Stål, 1872: 9.

Dinocoris piceus; Uhler, 1886: 5 (lista); Distant, 1880: 46-47, est. 5, fig. 4, 324 (suplemento) (identificação errada, ver A. innocens, p. 118); Lethierry \& Severin, 1893: 86 (catálogo).

Dinocoris mixtus; Lethierry \& Severin, 1893: 86 (catálogo).

Dinocoris variolosus; Lethierry \& Severin, 1893: 86.

Mecistorhinus (Mecistorhinus) piceus; Kirkaldy, 1909: 217 (catálogo).

Mecistorhinus (Mecistorhinus) unicolor; Kirkaldy, 1909: 217 (catálogo).

Mecistorhinus (Antiteuchus) mixtus; Kirkaldy, 1909: 217 (catálogo).

Mecistorhinus (Antiteuchus) variolosus; Kirkaldy, 1909: 218 (catálogo).

Mecistorhinus (Antiteuchus) fuscus Ruckes, 1959: 6. SIN. NOV.

Antiteuchus (Antiteuchus) subimpunctatus Ruckes, 1964: 64-65; Engleman \& Rolston, 1983: 179 (chave), 180. SIN. NOV.

Antiteuchus (Antiteuchus) mixtus; Ruckes, 1964: 63 (chave), 70-71, figs. 4, 11, 22-24; Engleman \& Rolston, 1983: 179 (chave).

Antiteuchus (Antiteuchus) variolosus; Ruckes, 1964: 63 (chave), 6667, figs. 7, 12, 17; Becker \& Grazia-Vieira, 1971: 22 (lista); Engleman \& Rolston, 1983: 179 (chave), 180-181, figs. 2, 4a, 9. Antiteuchus (Antiteuchus) fuscus; Ruckes, 1964: 63 (chave), 67, figs. 18-19; Engleman \& Rolston, 1983: 179 (chave).

Antiteuchus (Antiteuchus) piceus; Ruckes, 1964: 63 (chave), 67, 69 figs. 20-21; Becker \& Grazia-Vieira, 1971: 21 (lista); Engleman \& Rolston, 1983: 179 (chave).

Antiteuchus (Antiteuchus) subgibbus Engleman, 1983 (in Engleman \& Rolston, 1983): 179 (chave), 180. SIN. NOV.

Medidas $(\mathrm{n}=20)$ : comprimento total- 11,8-16,2; largura total- 7,5-10,5.

Corpo ovalado, giboso, coloração dorsal variando entre amarelo com manchas castanhas até totalmente negro. Pontuação profunda e densa, distribuída em agrupamentos de diferentes tamanhos e raramente formando linhas sinuosas transversais.

Segmentos antenais II e III sem setas. Segmentos antenais I e II castanho-claros com manchas amarelas. Segmento III castanho-claro com 1/3 apical amarelo. Segmentos IV e V amarelos com ou sem um anel negro mediano e de largura variável. Segmentos em ordem crescente de comprimento: II; I; III-V subiguais.

Rostro amarelo a castanho-escuro. Hemiélitro com ápice atingindo a metade posterior do conexivo VII. Escutelo com ápice arredondado atingindo a metade distal do urotergito VII. Ventralmente o tórax apresenta-se amarelo a amarelo-escuro com pontuação densa castanha à negra. Área evaporatória e ruga ostiolar castanho-escuras a negras. Mesopleura com um pequeno calo amarelo-pálido. Metapleura com ou sem uma pequena área calosa amarelo-pálido junto à margem externa. Coxas e trocânteres amarelo-escuros a castanho-escuros e imaculados. Fêmures amarelos recobertos por manchas castanhas. Tíbias amarelo-escuras a castanho-escuras com manchas mais claras; pêlos de comprimento menor que o diâmetro do segmento. Tarsos amarelo-escuros a castanhoescuros. Conexivo apresentando áreas intersegmentares castanho-escuras a negras alternadas com áreas amarelas; pontuação densa castanha a castanho-escura. Coloração dorsal do abdome castanha. Face ventral do abdome amarela, nos exemplares mais escuros a superfície ventral é quase totalmente recoberta por manchas castanho-escuras. Internamente aos espiráculos não ocorrem áreas de coloração amarela. Margem de cada segmento com uma mancha amarela mediana e de tamanho variável. Urotergito VII com um par de projeções largas, espessadas e com textura diferenciada na região mediana, entre o processo e a margem do urotergito VII. Sobre cada uma destas projeções inicia uma fileira de pêlos que estende-se até a margem do urotergito VII. Parte livre do processo mediano longa, larga, plana e curvada pósteroventralmente; ápice expandido, suavemente enrugado, margem posterior com uma lígula membranosa grande. Membrana mais larga na região mediana, antes da projeção espessada (fig. 267).

Pigóforo amarelo a castanho-claro com a região posterior castanho-escura entremeada por manchas amarelas. Escavação do bordo dorsal cerca de duas vezes mais larga que profunda (fig. 268). Projeções laterais ao segmento $X$ arredondadas. Processo superior do bordo ventral grande, arredondado, plano e negro. Em vista posterior, é possível ver uma grande concavidade na margem, onde encaixa-se o parâmero. Região mediana alta, convexa transversalmente e inclinada posteriormente, margem superior biconvexa e mais estreita que a extremidade do segmento X (fig. 269). Região lateral da superfície ventral, junto ao ângulo póstero-lateral do pigóforo, com um tufo denso de pêlos longos. Abaixo da região mediana ocorre uma área côncava sem elevação central, mas com um par de áreas levemente túmidas, laterais à linha média longitudinal, e recoberta por pêlos esparsos. Ângulo pósterolateral do pigóforo castanho e 1,3 vezes mais longo que largo em vista lateral (fig. 270). Ângulo mais longo que a área esclerotizada do segmento X. Face interna levemente côncava. Face dorso-lateral plana à levemente côncava apresentando uma elevação estreita e curta, em continuação ao processo látero-dorsal. Face ventral plana na base e levemente convexa na metade distal.

Cabeça do parâmero (figs. 271-272) composta por 3 lobos. Dorsal reduzido, globoso e projetado posteriormente; carena dorsal baixa e evanescente na base do lobo dorsal. Lobo lateral interno inconspícuo, provavelmente fundido ao lobo ventral. Lobo lateral externo amplo, triangular e curvado anteriormente. Lobo ventral amplo, sub-retangular e levemente côncavo, apresentando também uma grande projeção espiniforme lateral e levemente curvada ventralmente em direção à base do ângulo póstero-lateral do pigóforo.

Segmento $\mathrm{X}$ semicilíndrico; região látero-posterior levemente escavada, adiante da escavação e dirigida posteriormente, ocorre também um intumescimento que pode ou não formar um pequeno tubérculo (fig. 268). Face posterior plana ou levemente convexa. Área membranosa dorsal atingindo a face posterior. 
C. mixtus: Holótipo fêmea. "mixtus", "Type" ( ZMUC). Examinado. D. variolosus: Holótipo fêmea. "variolosus mihi", "Type Westwood (Hope) C. Hemipt. 1837 Part I, page 25 Distant PZS, 1900, p. $807-$ 825", "Type Hem: $\mathrm{n}^{\circ} 107$ Dinidor variolosus Westwood Hope Dept. Oxford" (OXUM). Examinado.

D. unicolor: Holótipo macho. "unicolor Hope", "Type Westwood (Hope) C. Hemipt. 1837 PartI, page 25 Distant PZS, 1900, p. 807-825", "Type Hem: no 110 Dinidor unicolor Westwood Hope Dept. Oxford" (OXUM). Examinado.

A. subgibbus: Holótipo fêmea. "Brasil, Amazonas, Lago Sta Rita Rio Solimões, 18-IX-1968 Eduardo" (AMNH). Examinado.

A. subimpunctatus: Holótipo fêmea. "Manaos", "Aug.", "Amazon Roman" (NHRS). Examinado. Ruckes (1964) acrescenta ainda a data, agosto-1914, e o nome completo do coletor, Abraham Roman.

Distribuição: Trinidad e Tobago, Trinidad: St. Augustine, Groovestate; Venezuela, Zulia; Araguá: El Limon, El Castaño; Carabobo: Belen; Amazonas: San Carlos de Rio Negro. GUIANA. Guiana Francesa, Cayenne, Ilet la Mere. Suriname, Brokopondo: Paramaribo, Brokopondo, Langamon Kondre. Brasil, Amapá: Serra do Navio; Amazonas: Manaus,Itacoatiara, Benjamin Constant, Estirão do Equador (04³3'S 71³8'W), Borba; Pará: Soure (Ilha de Marajó), Ponta de Pedras (Ilha de Marajó), Viseu, Belém, Acará, Tomé-Açú, Serra do Cachimbo; Maranhão: São Luis; Paraíba: Mamanguape; Mato Grosso: Cáceres, Barra do Tapirapé; Ceará: Fortaleza, Redenção; Goiás: Aragarças; Mato Grosso do Sul: Corumbá, Dourados; Minas Gerais: Santa Vitória; Bahia: Curaça, Icó, Santa Rita; Espirito Santo: São Mateus, Mimoso do Sul; Rio de Janeiro: Rio de Janeiro, Seropédica; São Paulo: Balsamo, São José do Rio Pardo, Nova Europa, Sumaré, Campínas, Valinhos, Sorocaba, São Paulo; Paraná: Rolândia, Londrina, Curitiba. Bolívia, La Paz: Inquisivi. Paraguai, Canendiyu: Salto del Guaíra; Central: Assunción, San lorenzo. Argentina, Formosa: Guaycolec; Tucumán: San Miguel de Tucumán, San Pablo; Salta: Salta.

Comentários: Dallas (1851) propôs a sinonímia de $D$. unicolor Westwood e A. piceus (Pal. Beauv.), provavelmente, com base na análise dos tipos de ambas as espécies. A sinonímia de $A$. piceus com $A$. mixtus, feita aqui, leva em consideração essa hipótese, mas baseia-se principalmente na descrição original de $P$. picea, onde o autor descreve como "característicos" a convexidade do corpo e a irregularidade da superfície dorsal, com suas linhas e escavações profundas. Esta textura e convexidade do corpo só são encontradas em $A$. mixtus. Além disto, a análise do tipo de $D$. unicolor não deixa dúvidas de que este é um exemplar macho de A. mixtus. Os exemplares analisados pertencem às coleções do AMNH, BMNH, CASC, DZUP, IBSP, UFRRJ, IMLA, INPA, IZAV, MCZN, MLPA, MNHN, MRSN, MZSP, ORST, MNRJ, RMNH, UFRG, NMNH e UYIC. A. mixtus pode ser identificado pela coloração dos machos, geralmente negros, e fêmeas, amarelas com manchas castanhas; pela pontuação dorsal profunda; pelo lobo dorsal do parâmero reduzido, globoso e projetado posteriormente; pelo lobo ventral dirigido pósteroventralmente; pela região látero-posterior do segmento $\mathrm{X}$ levemente escavada. A. mixtus compartilha com $A$. radians o corpo giboso; antenas recobertas apenas por sétulas; tíbias com pêlos de comprimento menor que o diâmetro do segmento; presença de uma fileira de pêlos que inicia sobre as projeções espessadas e estende-se até a margem do urotergito VII; pelas projeções espessadas do urotergito VII largas; pela cabeça do parâmero composta por 3 lobos: lobo lateral interno inconspícuo; lobo lateral externo amplo, triangular e curvado anteriormente; lobo ventral alongado, levemente côncavo e sub-retangular, apresentando também uma grande projeção espiniforme lateral.

\section{Antiteuchus radians Ruckes, 1964}

(Figs. 274-280, 309)

Antiteuchus (Antiteuchus) radians Ruckes, 1964: 62 (chave), 65-66, figs. 15-16.

Antiteuchus mixtus; Costa Lima, 1940: 55, figs. 243-244; Ruckes, 1964: 70

Medidas ( $\mathrm{n}=20)$ : comprimento total- 11,8-15,3; largura total$8,0-10,5$.

Corpo ovalado, giboso, coloração dorsal amarela com manchas castanho-escuras a negras. Não ocorre variação de cor entre machos e fêmeas. Pontuação pouco profunda e densa, distribuída em agrupamentos de diferentes tamanhos e formando algumas linhas sinuosas transversais.

Segmentos antenais II e III sem setas. Segmentos antenais I e II amarelos com manchas castanhas. Segmentos III-V negros com um anel basal e outro apical amarelos. Segmentos em ordem crescente de comprimento: II; I; III e IV subiguais; V.

Jugas com as margens externas apresentando a mesma cor da cabeça. Rostro castanho-escuro. Hemiélitro com ápice agudo atingindo a metade posterior do conexivo VII. Escutelo com ápice arredondado atingindo a metade distal do urotergito VII. Ventralmente o tórax apresenta-se amarelo com pontuação densa castanha à negra. Área evaporatória castanho-escura à negra. Ruga ostiolar negra com o ápice amarelo. Mesopleura com um pequeno calo amarelo-pálido. Metapleura com um grande calo amarelo-pálido junto à margem externa. Coxas e trocânteres amarelos a amarelo-escuros e imaculados. Fêmures amarelos recobertos por manchas escuras. Tíbias amarelas com o sulco dorsal e algumas grandes manchas dorsais castanho-escuras a negras; pêlos de comprimento menor que o diâmetro do segmento. Tarsos castanho-escuros. Conexivo apresentando áreas intersegmentares castanho-escuras a negras alternadas com áreas amarelas, pontuação esparsa e castanho-clara. Coloração dorsal castanha. Face ventral do abdome amarela à castanho-escura. Internamente aos espiráculos não ocorrem áreas de coloração amarela. Margem de cada segmento com uma mancha amarela mediana e de tamanho variável. Urotergito VII com um par de projeções largas, espessadas e com textura diferenciada na região mediana, entre o processo e a margem do urotergito VII. Sobre cada uma destas projeções inicia uma fileira de pêlos que estende-se até a margem do urotergito VII. Parte livre do processo mediano retangular, longa, estreita, plana e curvada póstero-ventralmente; ápice suavemente enrugado, margem posterior com uma grande lígula membranosa. Membrana mais estreita junto a projeção espessada (Fig. 274).

Pigóforo amarelo-escuro com a região posterior negra, 
exceto por uma faixa semicircular amarela que une os ângulos póstero-laterais do pigóforo. Escavação do bordo dorsal quase três vezes mais larga que profunda (fig. 275). Projeções laterais ao segmento $\mathrm{X}$ arredondadas. Processo superior do bordo ventral grande, arredondado, plano e negro. Em vista posterior, é possível ver uma grande concavidade na margem, onde encaixa-se o parâmero. Região mediana alta, convexa transversalmente e inclinada posteriormente, margem superior biconvexa e mais larga que a extremidade do segmento X (fig. 276). Região lateral da superfície ventral, junto ao ângulo póstero-lateral do pigóforo, com um tufo denso de pêlos longos. Abaixo da região mediana ocorre uma área côncava sem elevação central, mas com um par de áreas levemente túmidas, laterais à linha média longitudinal. Ângulo póstero-lateral do pigóforo 1,4 vezes mais longo que largo em vista lateral (fig. 277). Ângulo mais longo que a área esclerotizada do segmento $\mathrm{X}$. Face interna levemente côncava. Face dorso-lateral levemente côncava apresentando uma elevação estreita e curta, em continuação ao processo látero-dorsal; margem interna castanha, bem como a concavidade e algumas manchas dispersas. Face ventral plana na base e levemente convexa na metade distal; coloração geral amarela com exceção de uma faixa basal castanho-escura à negra.

Cabeça do parâmero (figs. 278-280) composta por 3 lobos. Dorsal reduzido, subcônico, projetado posteriormente e com a face interna plana; carena dorsal baixa e atingindo o ápice do lobo dorsal. Lobo lateral interno inconspícuo, provavelmente fundido ao lobo ventral. Lobo lateral externo amplo, triangular e curvado anteriormente. Lobo ventral amplo, sub-retangular, levemente côncavo e dirigido ventralmente, apresentando também uma grande projeção espiniforme lateral e levemente curvada ventralmente em direção à base do ângulo pósterolateral do pigóforo.

Segmento X semicilíndrico; região látero-posterior intumescida, dirigida posteriormente, podendo ou não formar um pequeno tubérculo (fig. 275). Face posterior levemente convexa. Área membranosa dorsal atingindo a face posterior.

Holótipo macho. "Rio de Janeiro, Brazil, April, 10, 1928" (AMNH). Examinado.

Distribuição: BRASIL, Espirito Santo: Baixo Guandú; Rio de Janeiro: Rio de Janeiro, Niterói; São Paulo: São Paulo; Paraná: Ponta Grossa, Curitiba; Santa Catarina: Stella Maris.

Comentários: Os exemplares analisados pertencem às coleções do DZUP, UFRRJ, MGAP, MZSP, MNRJ e UFRG. Esta espécie pode ser reconhecida pela pontuação dorsal pouco profunda; pela ausência de dimorfismo entre machos e fêmeas, pela parte livre do processo mediano do urotergito VII retangular; pelo lobo dorsal do parâmero subcônico e com a face interna plana; pelo lobo ventral dirigido ventralmente. As características expostas acima distinguem esta espécie de $A$. mixtus.

Antiteuchus macraspis (Perty, 1834)

(Figs. 281-287, 310)

Pentatoma macraspis Perty, 1834: 166, pl.33, fig. 7.
Dinocoris macraspis; Burmeister, 1835: 364; Lethierry \& Severin, 1893: 86 (catálogo); Distant, 1889: 323-324 (suplemento), pl. 29, fig. 19. Dinocoris annulatus Hahn, 1835: vol 3, 66, fig. 279.

Cataulax macraspis; Amyot \& Serville, 1843: 112 (nec Spinola). Antiteuchus annulatus; Dallas, 1851: 163.

Dinocoris (Dinocoris) macraspis; Stål, 1872: 7.

Neodine macraspis; Kirkaldy, 1909: 218 (catálogo).

Antiteuchus (Neodine) macraspis; Ruckes, 1961: 153; Ruckes, 1964: 59 (chave), 60-61, figs. 13-14; Becker \& Grazia-Vieira, 1971: 22 (lista); Engleman \& Rolston, 1983: 176.

Medidas ( $\mathrm{n}=20)$ : comprimento total- 9,7-12,0; largura total6,1-7,2.

Corpo levemente giboso, coloração dorsal amarela a amarelo-escura. Pontuação concentrada em linhas sinuosas longitudinais, raramente em linhas transversais, e não formando agrupamentos irregulares.

Artículos antenais II e III apresentam setas entre as sétulas. Segmentos antenais I e II amarelos a castanho-claros. Segmento III amarelo a castanho-claro com uma parte negra. Segmento IV e V negros com ou sem um pequeno anel basal amarelo. Em alguns exemplares ocorre uma mancha amarelopálida no ápice dos segmentos III e IV e na metade basal do V. Segmentos em ordem crescente de comprimento: II; I; III-V subiguais.

Rostro amarelo a amarelo-escuro. Hemiélitro com ápice ultrapassando a extremidade posterior do corpo; pontuação distribuída em faixas longitudinais castanhas a castanhoescuras. Escutelo com ápice agudo ultrapassando a extremidade do corpo; pontuação distribuída em faixas longitudinais castanhas a castanho-escuras. Ventralmente o tórax apresenta-se amarelo a amarelo-escuro com pontuação esparsa e recoberta por manchas castanhas. Área evaporatória castanha. Ruga ostiolar amarela. Mesopleura com um pequeno calo amarelo-pálido. Metapleura sem um calo amarelo junto à margem externa. Pernas amarelas a castanho-claras e imaculadas. Tíbias apresentando alguns pêlos com comprimento maior que o diâmetro do segmento. Conexivo amarelo com pontuação recoberta por manchas castanhas que podem ou não recobrir os ângulos laterais externos de cada segmento. Coloração dorsal do abdome amarela à amareloescura. Face ventral do abdome amarela; entre os tricobótrios e o ângulo póstero-lateral de cada segmento, ocorre um número maior de manchas castanhas que podem formar, em alguns casos, uma única mancha oblíqua. Pode ou não ocorrer uma mancha amarelo-pálida ao redor de cada espiráculo. Urotergito VII com um par de projeções arredondadas, espessadas e com textura diferenciada na região mediana entre o processo e a margem do urotergito VII. Estas projeções limitam a distribuição de uma fileira de pêlos à região mediana do urotergito VII. Parte livre do processo mediano longa, larga, plana e curvada póstero-ventralmente; ápice levemente expandido e suavemente enrugado, margem posterior com uma lígula membranosa bem desenvolvida. Membrana com largura constante (fig. 281).

Pigóforo amarelo-escuro. Escavação do bordo dorsal quase duas vezes mais larga que profunda (fig. 282). Projeções laterais ao segmento $\mathrm{X}$ dentiformes. Processo superior do bordo ventral 
grande, arredondado, com a margem curvada ventralmente e negro, apresentando ainda uma pequena escavação na base. Em vista posterior, é possível ver uma grande concavidade na margem, onde encaixa-se o parâmero. Região mediana alta, levemente convexa transversalmente e inclinada posteriormente, margem superior biconvexa e tão larga quanto a extremidade do segmento X (fig. 283). Região lateral da superfície ventral, junto ao ângulo póstero-lateral do pigóforo, com um tufo denso de pêlos longos. Abaixo da região mediana ocorre uma área côncava sem elevação central. Ângulo pósterolateral do pigóforo 1,2 vezes mais longo que largo em vista lateral (fig. 284). Ângulo pouco mais longo que a área esclerotizada do segmento X. Face interna plana e com alguns sulcos longitudinais. Face dorso-lateral côncava. Face ventral plana e sem pontos.

Cabeça do parâmero (figs. 285-287) composta por 4 lobos. Dorsal reduzido e cônico; carena dorsal quase inconspícua e evanescente antes da base do lobo dorsal. Lobo lateral interno amplo, longo, delgado, largo, afilado em direção ao ápice e curvado posteriormente. Lobo lateral externo largo, triangular e curvado anteriormente. Lobo ventral triangular, levemente convexo transversalmente, reto e com ápice dirigido para base do ângulo póstero-lateral do pigóforo.

Segmento X semicilíndrico; região látero-posterior intumescida e dirigida posteriormente, formando ou não um pequeno tubérculo (fig. 282). Face posterior levemente convexa. Área membranosa dorsal atingindo a metade da parte esclerotizada do segmento.

Holótipo macho. “Provincia St. Pauli” (ZSMC). Solicitou-se o tipo mas nunca houve resposta do curador da coleção. Ruckes (1964) examinou o tipo e identificou muitos exemplares que, por sua vez, foram examinados neste trabalho.

Distribuição: Costa Rica, Guapiles. Panamá, Canal Zone: Lago Gatún, Barro Colorado Isl., Coco Solo Hospital. Colômbia, Huila: Gigante. Venezuela, Araguá: Maracay; Carabobo; Tachira: San Antonio, Rio Frio; Amazonas: San Carlos de Rio Negro. Suriname, Nickerie: Sipaliwini. Guiana Francesa. Brasil, Amazonas: Manaus, Estirão do Equador; Pará: Tomé-Açú, Bragança; Rio Grande do Norte: Natal; Paraíba: Mamanguape; Ceará: Fortaleza; Pernambuco; Mato Grosso: Parecis; Bahia: Salvador; Rio de Janeiro: Rio de Janeiro; São Paulo: Bálsamo, Jabuticabal, Ibitinga. Perú, Madre de Dios: Reserva Rio Tambopata-Puerto Maldonado.

Comentários: Os exemplares analisados pertencem às coleções da CASC, DZUP, IBSP, INPA, IZAV, MPEG, MZSP, RMNH, UFRG e NMNH. Esta espécie pode ser identificada pela membrana do urotergito VII com largura constante; pelo lobo dorsal do parâmero reduzido e cônico; pelo lobo lateral interno amplo, longo, largo, afilado em direção ao ápice e curvado posteriormente; pelo lobo ventral triangular, levemente convexo transversalmente e reto; pelo segmento $\mathrm{X}$ com a região látero-posterior intumescida e dirigida posteriormente, formando ou não um pequeno tubérculo; pela face ventral do abdome com um grande número de manchas castanhas que podem formar, em alguns casos, uma única mancha oblíqua entre os tricobótrios e o ângulo póstero-lateral de cada segmento. A. macraspis compartilha com A. schuhi e A. variegatus a pontuação dorsal concentrada em linhas sinuosas longitudinais recobertas por faixas castanhas a castanho-escuras; a coloração geral amarelo-clara; o escutelo com ápice agudo ultrapassando a extremidade do corpo; a fileira de pêlos do urotergito VII restritos a sua região mediana, distribuição limitada pelas projeções espessadas; o hemiélitro com ápice ultrapassando a extremidade posterior do corpo; o processo superior do bordo ventral do pigóforo com uma pequena escavação na base. A. macraspis e A. schuhi têm em comum o $1 / 3$ posterior do disco pronotal com a pontuação interligada por faixas negras.

Antiteuchus schuhi Engleman, 1983

(Figs. 288-294, 310)

Antiteuchus (Neodine) schuhi Engleman, 1983 (in Engleman \& Rolston, 1983): 176-178, fig. 7 .

Medidas ( $\mathrm{n}=2)$ : comprimento total- 15,4-17,7; largura total9,2-9,77.

Corpo levemente giboso, coloração dorsal amarela à amarelo-escura. Pontuação densa e concentrada em linhas sinuosas longitudinais, raramente em linhas transversais, e sem formar manchas.

Artículos antenais II e III apresentam setas entre as sétulas. Segmentos antenais I e II castanhos. Segmento III negro. Segmento IV e V ausentes em um dos exemplares e fundidos no outro, segundo a descrição de Engleman (1983) os artículos IV e V são totalmente negros. Segmentos em ordem crescente de comprimento: II; I; III.

Rostro amarelo a amarelo-escuro. Hemiélitro com ápice agudo ultrapassando a extremidade posterior do corpo; pontuação distribuída em faixas longitudinais. Escutelo com ápice agudo ultrapassando a extremidade do corpo; pontuação distribuída em faixas longitudinais castanhas a castanhoescuras. Ventralmente o tórax apresenta-se amarelo com pontuação densa, recoberta por manchas castanhas a castanho-escuras. Área evaporatória castanho-escura à negra. Ruga ostiolar amarela. Mesopleura com um pequeno calo amarelo-pálido. Metapleura sem um calo junto à margem externa. Pernas amarelas à castanho-claras e imaculadas. Tíbias não apresentando pêlos mais longos que o diâmetro do segmento. Conexivo amarelo-escuro a castanho com pontuação densa, margem externa amarelo-pálida. Coloração dorsal do abdome amarela com faixas castanhas longitudinais. Face ventral do abdome amarela; uma faixa lateral que inclui os espiráculos e tricobótrios apresenta coloração mais escura. Pode ou não ocorrer uma mancha ao redor de cada espiráculo. Urotergito VII com um par de projeções arredondadas, espessadas e com textura diferenciada na região mediana entre o processo e a margem do urotergito VII. Estas projeções limitam uma fileira de pêlos que inicia junto ao processo mediano do urotergito VII. Parte livre do processo mediano curta, estreita na base, plana, reta e dirigida pósteroventralmente; ápice expandido e suavemente enrugado, 
margem posterior com uma grande lígula membranosa. Região expandida maior que o restante do processo mediano do urotergito VII. Membrana mais larga na região mediana (fig. 288).

Pigóforo amarelo-escuro. Escavação do bordo dorsal cerca de quatro vezes mais larga que profunda (fig. 289). Projeções laterais ao segmento $\mathrm{X}$ arredondadas. Processo superior do bordo ventral grande, arredondado, com a margem curvada ventralmente e negro, apresentando ainda uma pequena escavação na base. Em vista posterior, é possível ver uma grande concavidade na margem, onde encaixa-se o parâmero. Região mediana alta, levemente convexa transversalmente e inclinada posteriormente, margem superior côncava e mais larga que a extremidade do segmento X (fig. 290). Região lateral da superfície ventral, junto ao ângulo póstero-lateral do pigóforo, com um tufo denso de pêlos longos. Abaixo da região mediana ocorre uma ampla área côncava sem elevação central. Ângulo póstero-lateral do pigóforo 1, 3 vezes mais longo que largo em vista lateral (fig. 291). Ângulo pouco mais longo que a área esclerotizada do segmento X. Face interna plana e com alguns sulcos longitudinais. Face dorso-lateral plana. Face ventral plana e sem pontos.

Cabeça do parâmero (figs. 292-294) composta por 4 lobos. Dorsal fundido ao lobo lateral externo, amplo, transversal e levemente inclinado posteriormente, margem dorsal com uma grande área suavemente achatada e rebatida láteroanteriormente; carena dorsal pouco desenvolvida, quase inconspícua e evanescente antes da base do lobo dorsal. Lobo lateral interno amplo, reniforme, convexo e envolvendo a margem do lobo dorsal, margem levemente espessada. Lobo lateral externo projetado anteriormente. Lobo ventral subretangular, levemente convexo e dirigido ventroposteriormente, apresenta uma projeção lateral, triangular e curvada em direção à base do ângulo póstero-lateral do pigóforo.

Segmento X semicilíndrico; áreas látero-posteriores não intumescidas e projetadas posteriormente formando estruturas parecidas com os tubérculos do segmento X, embora estejam implantadas longitudinalmente sobre a face posterior (fig. 289). Face posterior plana e muito inclinada, quase perpendicular ao plano frontal do pigóforo. Área membranosa dorsal atingindo a base dos tubérculos.

Holótipo macho. "Brasil-MT Lat $12^{\circ} 31^{\prime}$ \& Long 55³7', Sinop, out. 1974 M. Alvarenga” (AMNH). Examinado.

\footnotetext{
Distribuição: Brasil, Mato Grosso: Sinop. Equador, Napo: Mijahvalli.

Comentários: Os exemplares examinados pertencem às coleções do AMNH e BMNH. Esta espécie pode ser identificada pela pontuação dorsal densa e a grande quantidade de faixas longitudinais castanhas onde estão concentrados estes pontos; pela face ventral do abdome com uma faixa lateral escura que inclui os espiráculos e tricobótrios; pelo lobo dorsal do parâmero transversal e levemente inclinado posteriormente, margem com uma grande área suavemente achatada e rebatida
}

látero-anteriormente; pelo lobo lateral interno amplo e reniforme; pelo lobo ventral sub-retangular; pelo pequeno tamanho do segmento X em relação ao pigóforo. A. schuhi e $A$. variegatus possuem em comum o processo mediano do urotergito VII com a região expandida maior que o restante do processo; o segmento $\mathrm{X}$ sem áreas látero-posteriores intumescidas; a face posterior do segmento X plana e muito inclinada, quase perpendicular ao plano frontal do pigóforo.

\section{Antiteuchus variegatus Dallas, 1851}

(Figs. 295-301, 310)

Antiteuchus variegatus Dallas, 1851: 163; Walker, 1867: vol. 1, 198 (lista).

Dinocoris (Dinocoris) variegatus; Stål, 1872: 7.

Dinocoris variegatus; Lethierry \& Severin, 1893: 86 (catálogo).

Neodine variegatus; Kirkaldy, 1909: 218 (catálogo).

Antiteuchus (Neodine) variegatus; Ruckes, 1961: 153; Ruckes, 1964: 59 (chave), 60; Engleman \& Rolston, 1983: 175 (chave), 178, figs. 5,8 .

Medidas ( $\mathrm{n}=5)$ : comprimento total- 16,2-16,7; largura total9,8-10,5

Corpo levemente giboso, coloração dorsal amarela à amarelo-escura. Pontuação concentrada em linhas sinuosas longitudinais castanho-escuras, raramente em linhas transversais, e não formando manchas.

Artículos antenais II e III apresentam setas entre as sétulas. Segmento antenal I amarelo. Segmento II negro, com ou sem um anel amarelo na base. Segmento III-V negros, sendo que o $\mathrm{V}$ pode ter o ápice amarelo-escuro. Segmentos em ordem crescente de comprimento: II; I; III-V subiguais.

Rostro amarelo a amarelo-escuro. Hemiélitro com ápice agudo ultrapassando a extremidade posterior do corpo; pontuação distribuída em faixas longitudinais castanhas a castanho-escuras de largura variável. Escutelo com ápice agudo ultrapassando a extremidade do corpo; pontuação distribuída em faixas longitudinais castanhas a castanhoescuras de largura variável. Ventralmente o tórax apresenta-se amarelo a amarelo-escuro com pontuação esparsa e recoberta por manchas castanhas. Área evaporatória castanha à castanho-escura. Ruga ostiolar amarela. Mesopleura com um pequeno calo amarelo-pálido. Metapleura sem um calo junto à margem externa. Pernas amarelas à castanho-claras e imaculadas. Tíbias não apresentando pêlos mais longos que o diâmetro do segmento. Conexivo amarelo com pontuação recoberta por manchas castanhas restrita a região mediana longitudinal. Coloração dorsal do abdome amarela à amareloescura. Face ventral do abdome amarela com algumas manchas castanhas entre os espiráculos e a margem lateral. Urotergito VII com um par de projeções arredondadas, espessadas e com textura diferenciada na região mediana entre o processo e a margem do urotergito VII. Estas projeções limitam uma fileira de pêlos que inicia junto ao processo mediano do urotergito VII. Parte livre do processo mediano longa, larga, plana e curvada póstero-ventralmente; ápice expandido e suavemente enrugado, margem posterior com uma grande lígula membranosa. Membrana com largura constante (fig. 295). 
Pigóforo amarelo-escuro. Escavação do bordo dorsal quase duas vezes mais larga que profunda (fig. 296). Projeções laterais ao segmento $\mathrm{X}$ arredondas. Processo superior do bordo ventral grande, arredondado, com a margem curvada ventralmente e negro, apresentando ainda uma pequena escavação na base. Em vista posterior, é possível ver uma grande concavidade na margem, onde encaixa-se o parâmero. Região mediana alta, levemente convexa transversalmente e inclinada posteriormente, margem superior côncava e mais larga que a extremidade do segmento X (fig. 297). Região lateral da superfície ventral, junto ao ângulo póstero-lateral do pigóforo, com um tufo denso de pêlos longos. Abaixo da região mediana ocorre uma grande área côncava e rasa, sem elevação central. Ângulo póstero-lateral do pigóforo 1,2 vezes mais longo que largo em vista lateral (fig. 298). Ângulo pouco mais longo que a área esclerotizada do segmento X. Face interna plana, com alguns sulcos longitudinais. Face dorso-lateral levemente côncava. Face ventral plana e sem pontos.

Cabeça do parâmero (figs. 299-301) composta por 4 lobos. Dorsal fundido ao lateral externo, amplo e estreito, margem dorsal convexa, com uma área longa e intumescida junto ao lobo lateral interno; carena dorsal baixa e atingindo a margem superior do parâmero. Lobo lateral interno grande, estreito, baixo, afilado em direção ao ápice e curvado posteriormente. Lobo lateral externo largo, triangular e curvado láteroanteriormente. Lobo ventral sub-retangular, curvado pósteroventralmente e dobrado lateralmente, apresentando uma projeção lateral triangular e dirigido para base do ângulo póstero-lateral do pigóforo; ângulo póstero-lateral interno formando uma pequena projeção achatada e papiliforme.

Segmento X semicilíndrico; áreas látero-posteriores não intumescidas e projetadas posteriormente formando estruturas parecidas com os tubérculos do segmento X, embora estejam implantadas longitudinalmente sobre a face posterior (fig. 296). Face posterior plana e muito inclinada, quase perpendicular ao plano longitudinal do pigóforo. Área membranosa dorsal atingindo a base dos tubérculos.

Holótipo fêmea. "Para", "Messrs. Wallace and Bates's collection" (BMNH). Examinado.

Distribuição: Brasil, Amazonas: Parque Nacional do Jaú, Borba; Mato Grosso: Sinop (12³1'S 55³7’W). Perú, Loreto: Rio Tapiche. Bolívia, La Paz: La Paz.

Comentários: Os exemplares examinados pertencem às coleções do AMNH, CASC e MCNZ. Esta espécie pode ser reconhecida pela face ventral do abdome com algumas manchas castanhas entre os espiráculos e a margem lateral; pela margem dorsal do parâmero com uma área longa e intumescida junto ao lobo lateral interno; pelo lobo lateral interno do parâmero alongado, estreito e curvado posteriormente; pelo lobo ventral sub-retangular, alongado, levemente curvado lateralmente, apresentando os ângulos póstero-laterais projetados.

\section{Empicoris marmoreus Spinola, 1837 -}

Insertae sedis e Species inquirenda

Esta espécie foi removida de Antiteuchus pois o tipo não foi encontrado na coleção do Museu Regionale di Torino, Itália, onde estão depositados os tipos de Heteroptera de Spinola. A descrição original é bastante curta e geral, não permitindo sequer a inclusão da espécie em Antiteuchus.

Antiteuchus tatei (Ruckes, 1958) - Species inquirenda

Ao descrever esta espécie, Ruckes (1958) designou o AMNH como local de depósito do exemplar-tipo. Os autores não localizaram este exemplar na coleção do AMNH, estando, portanto, desaparecido. Segundo a descrição de Ruckes, o exemplar certamente faz parte do grupo formado por $A$. macraspis, A. schuhi e A. variegatus. O problema é que o único exemplar conhecido é uma fêmea com padrão de coloração semelhante ao das outras três espécies. Como já mencionado neste trabalho a genitália de fêmea bem como variações de coloração não podem ser utilizados como caracteres para identificar uma espécie. Concluiu-se, portanto, que essa fêmea pode pertencer a qualquer uma das três espécies citadas acima.

Agradecimentos. Aos curadores das coleções que cederam exemplares, especialmente os tipos: Dr. R. Schuh (AMNH), Mick Webb (BMNH), Dr. P. H. Arnaud Jr. (CASC), Dra. L. Marinoni (DZUP), Dr. J. Jurberg (FIOC), Dra E. Bergman (IBSP), Dra M. Toledo (IMLA), Dr. J. A. Rafael (INPA), Dr. E. Osuna (IZAV), Dra H. Gastal (MCZN), F. Meyer (MGAP), Dra. M. C. Coscarón (MLPA), Dra. D. Plüot-Sigwald (MNHN), Dra Ana Harada (MPEG), Dra C. Costa (MZSP), † Dr. P. Lindskog (NHRS), Dr. A. Lago (MNRJ), Dr. T. Henry (NMNH), Dr. G. Couturier (ORST), Dr. I. Lansbury (OXUM), Dr. P. van Doesburg (RMNH), Dr. C. Michener (SEMC), Dra. N. Aguiar (UFAM), Dr. J. Pujol-Luz (UFRRJ), Dr. C. Casini (UYIC), Dr. J. Deckert (ZMHB), † Dr. N. M. Andersen (ZMUC), Dr. K. Schönitzer (ZSMC). A FAPESP pela concessão da bolsa de doutorado processo $n^{\circ}$ 94/1256-6.

O primeiro autor agradece ao Dr Sérgio Vanin por seu apoio e ensinamentos. Aos revisores que fizeram contribuições importantes a este trabalho.

\section{REFERÊNCIAS}

Amyot, C. J. B. \& A. Serville. 1843. Histoire naturelle des insectes. Hémiptères. Paris, Librairie Encyclopédique de Roret, 675 p.

Becker, M. \& J. Grazia. 1985. Revisão do gênero Dinocoris Burmeister, 1835 (Heteroptera, Pentatomidae, Discocephalinae). Revista Brasileira de Zoologia 3: 65-108.

Becker, M. \& J. Grazia-Vieira. 1971. Contribuição ao conhecimento da superfamília Pentatomoidea na Venezuela (Heteroptera). Iheringia, Série Zoologia, 40: 3-26.

Burmeister, H. 1835. Handbuch der Entomologie. Berlin, Vol. 2, $1050 \mathrm{p}$.

Costa Lima, A. da. 1940. Insetos do Brasil. Rio de Janeiro, Escola nacional de Agronomia, Vol. 2, 351 p., 446 figs.

Dallas, W. S. 1851. List of the specimens of hemipterous insects in the collection of the British Museum. London, part 1, 390 p. 15 pls.

Distant, W. L. 1880-1893. Rhynchota-Hemiptera: Heteroptera. In: Godman, F., and O. Salvin, Biologia Centrali-Americana. London, vol. 1, 462 pp. 39 pls.

Distant, W. L. 1899. Rhynchotal notes III. Heteroptera: Discocephalinae and Pentatominae (part). Annals and Magazine 
of Natural History, ser. 7, 4: 421-445.

Dupuis, C. 1970. Heteroptera, p. 190-208. In: S. L. Tuxen (ed.) Taxonomist's glossary of genitalia of insects. Copenhagen, Munskgaard.

Engleman, H. D. 1976. Antiteuchus rolstoni, a new species of Discochephalinae from Colombia (Hemiptera: Pentatomidae). Journal of Kansas Entomological Society 49: 533-536.

Engleman, H. D. \& L. H. Rolston. 1983. Eight new species of Antiteuchus Dallas (Hemiptera: Pentatomidae). Journal of Kansas Entomological Society 56: 175-189.

Erichson, W. F. 1848. Insekten. In Schomburgk, R., Reisen in Britisch Guiana. Leipzig, Vol. 3, p. 553-617.

Fabricius, J. C. 1787. Mantissa insectorum sistems species nuper detectas adjectis synonymis, observationibus, descriptionibus, emendationibus. Copenhagen, Tomo II, $382 \mathrm{p}$.

Fabricius, J. C. 1794. Entomologia systematica emendata et aucta, secundum classes, ordines, genera, species, adjectis, synonymis, locis, observationibus. Copenhagen, Vol. 4, 472 p.

Fabricius, J. C. 1803. Systema rhyngotorum secundum ordines, genera, species, adjectis, synonymis, locis, observationibus, descriptionibus. Brunsvigae, Vol. 6, $314 \mathrm{p}$.

Fieber, F. X. 1851. Rhynchotographieen. Abhandlungen der Böhmischen Gesellschaft der Wissenschaften 7: 477-488.

Fieber, F. X. 1860. Die europäischen Hemiptera. Halbflügler (Rinchota Heteroptera). Nach der analytischen Methode bearbeitet. Gerold, Wien, i-vi, 1-112 p.

Froeschner, R. C. 1979. Heteroptera in an oft-overlooked paper of P.R. Uhler (Hemiptera). Proceedings of the Entomological Society of Washington 81: 653-656.

Froeschner, R. C.1981. Heteroptera or true bugs of Ecuador: A partial catalog. Smithsonian Contributions to Zoology 322: $151 \mathrm{p}$.

Gmelin, J. F. 1793. Caroli A. Linné Systema Naturae. Leipzig, Tomo I, pars VI. Editio decima tertia. p. 2151.

Hahn, C. W. 1835. Die Wanzenartigen Insekten. Nurenberg, C. M. Zeh'schen, Vol. 3, pp. 64-66.

Herrich-Schäeffer, G. A. W. 1844. Die Wanzenartigen Insekten. Nurenberg, C. M. Zeh'schen, Vol. 7, pp. 45-46, 63.

Kirkaldy, G. W. 1904. Biological and nomenclatorial notes on the Hemiptera, 3. Entomologist 37: 279-283.

Kirkaldy, G. W. 1909. Catalogue of the Hemiptera (Heteroptera). 1- Cimicidae. Berlin, Felix L. Dames, XL+392 p.

Lethierry, L. \& G. Severin. 1893. Catalogue Général des Hemiptéres. Tome I. Hétéroptères Pentatomidae. Bruxelles, Mus. R. Hist. Nat. Belgique, $\mathrm{X}+286$ p.

Palisot de Beauvois, A. M. F. J. 1808. Recueillis en Afrique et en Amérique, dans les royaumes d'Oware et de Benin, à SaintDominingue et dans les États-Unis, pendant les anneés 17861797. Paris, Schoell et Cia., 267 p. 90 pls.

Perty, M. 1834. Delectus animalium articulatorum, quae in itinere per Basilian anins 1817-1820, jussu et auspiciis Maximiliani Josephi Bavarie regis augustissimi peracte, collegerunt Dr. J.B. de Spix et Dr. C.F. Ph. de Martius. Munique, Imprensis, 270 p. 40 pls.
Rolston, L. H. 1991. Antiteuchus ruckesi, a new Discocephalinae from Peru (Hemiptera: Pentatomidae). Journal of the New York Entomological Society 99: 235-239.

Rolston, L. H. 1993. A key and diagnosis for males of the Incurvaria species-group of Antiteuchus Dallas with description of three new species (Hemiptera: Pentatomidae: Discocephalinae Journal of the New York Entomological Society 101: 108-129.

Ruckes, H. 1958. New genera and species of Neotropical discocephaline and halyine pentatomids (Heteroptera, Pentatomidae). American Museum Novitates (1868): 1-27.

Ruckes, H. 1959. Three new species of Mecistorhinus Dallas (Heteroptera, Pentatomidae). American Museum Novitates (1930): $1-8$.

Ruckes, H. 1961. Notes on the Mecistorhinus-Antiteuchus generic complex of Discocephalinae pentatomids (Heteroptera, Pentatomidae). Journal of the New York Entomological Society 69: 147-156.

Ruckes, H. 1964. The genus Antiteuchus Dallas, with descriptions of new species (Heteroptera, Pentatomidae, Discocephalinae). Bulletin of the American Museum of Natural History 127: 47-102.

Spinola, M. 1837 Essai sur les genres d'ínsectes apparentmants à l'ordre des Hémipteres, Lin. ou Rhyngotes, Fab. et à la section des Hétéroptères, Dufour. Genoa, 383 p.

Stål, C. 1855. Nya Hemiptera. Öfversigt af Kongliga VetenskapsAkademiens Förhandlingar 12: 181-192.

Stål, C. 1859. Hemiptera species novas. Konglika Svenska Fregattens Eugenies Resa omkrieng Jorden. Stockholm, 617 p.

Stål, C. 1860. Bidrag till Rio de Janeiro-traktens Hemipter-fauna. Kongliga Svenska Vetenskaps-Akademiens Handlingar 2: $1-84$.

Stål, C. 1864. Hemiptera nonnulla nova vel minus cognita. Annales de la Societé Entomologique de France $4: 47-68$.

Stål, C. 1867. Bidrag till hemipterernas systematic. Öfversigt af Kongliga Vetenskaps-Akademiens Förhandlingar 24: 491560 .

Stål, C. 1868. Hemiptera Fabriciana. Kongliga Svenska VetenskapsAkademiens Handlingar 7: 1-148.

Stål, C. 1872. Enumeratio hemipterorum II. Kongliga Svenska Vetenskaps-Akademiens Handlingar: 1-159.

Uhler, P. R. 1869. Notices of the Hemiptera obtained by the expedition of Prof. James Orton in Ecuador and Brazil. Proceedings of Boston Natural History Society 12: 321-327.

Uhler, P. R. 1886. Check-list of the Hemiptera Heteroptera of the North America. Brooklyn Entomological Society 1886: 5.

Walker, F. 1867. Catalogue of the specimens of heteropterousHemiptera in the collection of the British Museum. London, British Museum, parts 1-3, 599 p.

Westwood, J. O. 1837. Catalogue of the Hemiptera in the collection of the Rev. Hope, M.A. London, J. C. Bridgewater, Parte I, 46 p. 